


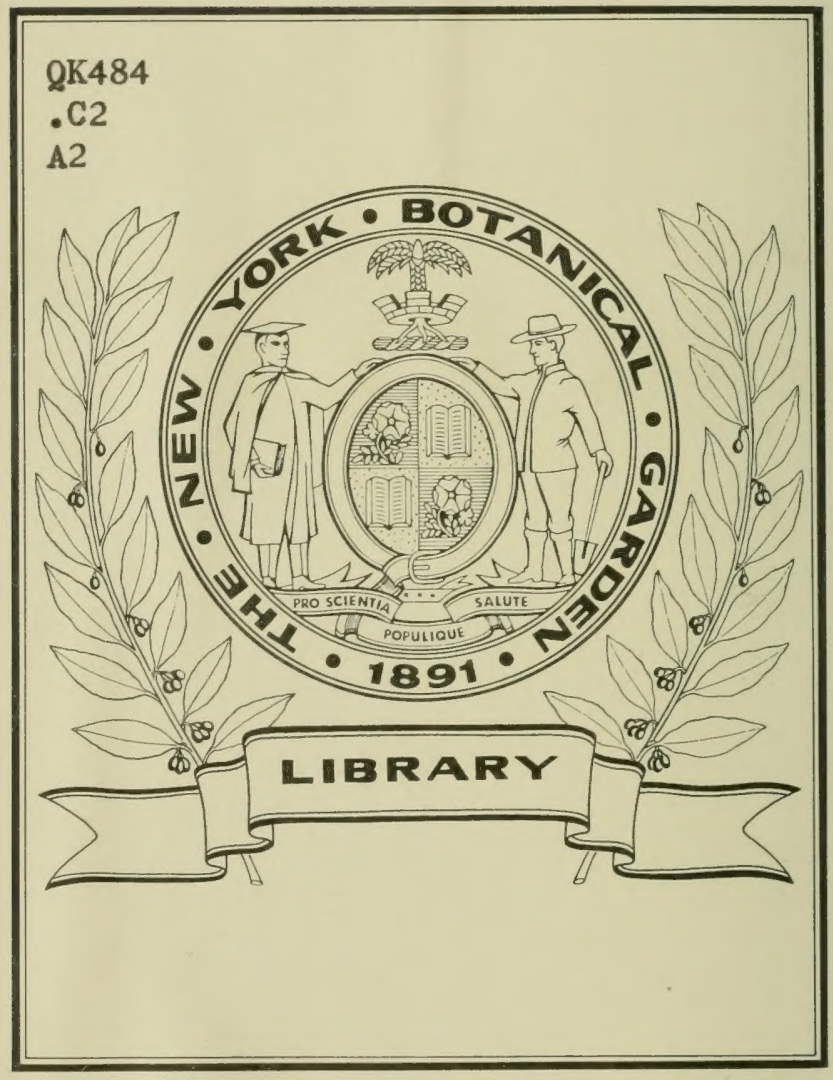




A Phytogeographic and Taxonomic Study of the Southern California

\section{Trees and Shrubs}

BY LEROY ABRAMS

Reprinted from the Bulletin of the Nrw York Botanical Garden, Vol. Vi., No. 2 I

Issued in advance, September, I9ro 


$$
\begin{aligned}
& .{ }_{2} \\
& A_{2}
\end{aligned}
$$


A PHYTOGEOGRAPHIC AND TAXONOMIC STUDY OF THE SOUTHERN CALIFORNIA TREES AND SHRUBS

BY LEROY ABRAMS 
[From the BULLETIN OF THE NHW YORK BOTANICAL GaRden, Vol. 6, No. 2I. I9IO.]

\section{A Phytogeographic and Taxonomic Study of the Southern California Trees and Shrubs}

By LeRoy ABrams

CONTENTS

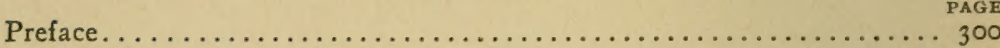

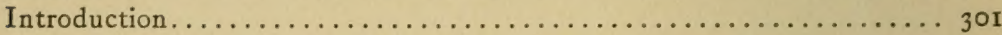

Physiography..........................

Climatology ................................... 304

General description........................... 304

Temperature and rainfall records. . . . . . . . . . . . 305

Phytogeographic features......................... 307

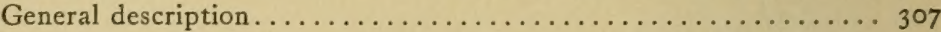

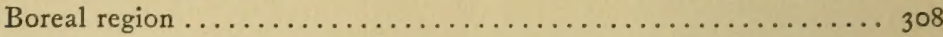

General description...................... 308

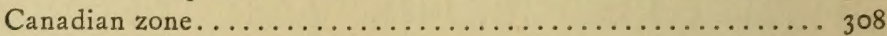

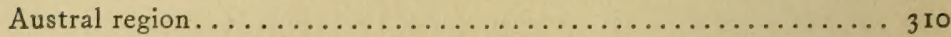

General description........................... 310

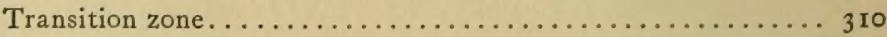

Upper austral zone...................... 312

General description..................... 312

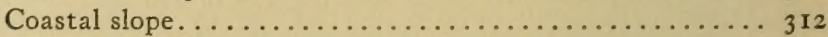

Desert slopes........................ 317

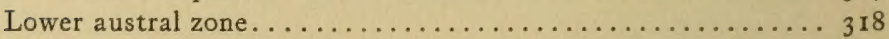

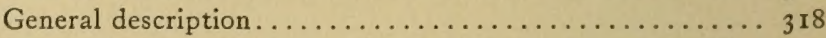

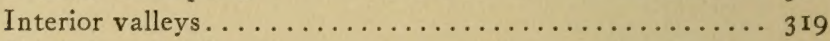

San Diego district. . . . . . . . . . . . . . 319

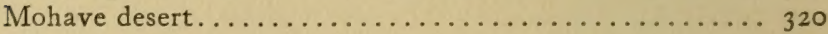

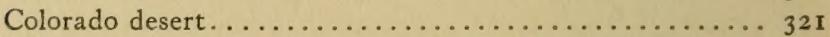

Explanation of plates.............................. 322

Annotated catalogue of the southern California trees and shrubs...... 323

\section{PREFACE}

In the study of the trees and shrubs of southern California I have endeavored to discuss the phytogeographic as well as the taxonomic features, as trees and shrubs, being long-lived and non-migratory, furnish excellent material for phytogeographic observations. The present paper is the result of field studies carried on along these lines for a number of years, together with an examination of specimens in the principal herbaria of the United States.

Many helpful suggestions in the study of the phytogeographical 
problems have been obtained from Coville's "Botany of the Death Valley Expedition," Parish's "Sketch of the Flora of Southern California," and Hall's "Survey of San Jacinto Mountain," as well as from Merriam's paper dealing with his system of life zones, which latter I have adopted.

Acknowledgments are most heartily given to the following persons for the loan of material, or for assistance in determining questions of taxonomy and nomenclature: Dr. B. L. Robinson, Mr. F. V. Coville, Dr. J. N. Rose, Dr. J. K. Small, Dr. P. A. Rydberg, Dr. H. M. Hall, Mr. S. B. Parish, Dr. A. Davidson, Mr. W. F. Wight, Mr. C. R. Ball, Mr. P. L. Ricker, Mrs. K. Brandegee and Miss M. A. Day.

To Professor W. R. Dudley, who has courteously given much time and valuable assistance, and through whose advice and encouragement I undertook the study of the southern California flora, and to Dr. N. L. Britton, who has given valuable aid in carrying on these studies, is due whatever merit this paper may possess.

\section{INTRODUCTION}

\section{PHYSIOGRAPHY}

Southern California is the name popularly applied to that part of the State of California which lies south of Point Conception and the Tehachapi Mountains, a territory lying between $32^{\circ} 35^{\prime}$ and $35^{\circ} 45^{\prime}$ north latitude, and extending from the 37 th to the $43 \mathrm{~d}$ meridian west. Its western boundary is the Pacific Ocean, its southern Lower California, and its eastern the Colorado River, which separates it from Arizona. On the north the boundary is formed by the crosss ranges which break up the general trend of the Coast Ranges and the Sierra Nevada. Its line extends from Point Conception eastward along the Santa Ynez Mountains, Mount Pinos, and the Tehachapi Mountains to the southern extremity of the Sierra Nevada, thence eastward to the southern boundary of Nevada. East of the Sierra Nevada the northern boundary is arbitrary, as the Mohave Desert merges into the desert regions northward and eastward with no definite line of demarcation.

The area comprised within these boundaries is approximately II 3,250 square kilometers, a little over one fourth that of the entire State. The greatest width from east to west is 520 kilo- 
meters, and from north to south 350 kilometers. Southern California covers an area somewhat greater than the entire State of Pennsylvania. If placed on the northern Atlantic coast it would extend east and west from Boston to Buffalo, and southward as far as Philadelphia.

The topography is broken and irregular, with numerous mountain ranges separated by narrow passes or valleys of greater or less extent. The main axis of these mountains lies generally parallel with the coast at a distance of 40 to $\mathbf{I} 20$ kilometers inland. At intervals of 60 to 100 kilometers narrow passes divide this axis into several rather distinct sections. Of these sections the northernmost, which lies between Tejon and Soledad Passes, is composed of a series of comparatively low, chaparral-covered mountains, the culminating peak of which (Liebre Mountain) is only 1737 meters above the sea. South of Soledad Pass, between it and Cajon Pass, are the rugged peaks of the San Gabriel Mountains, which rise abruptly out of the coastal valleys to altitudes ranging from I 800 to over 3000 meters (Mount San Antonio $=3024$ meters). The San Bernardino Mountains, although less broken and irregular, reach even higher altitudes. In this range, which is separated by the narrow Cajon Pass from the San Gabriel Mountains, is the highest mountain south of the Sierra Nevada (San Gorgonio, 3428 meters). Extending southeastward from Mount San Gorgonio, at a much lower altitude, are the desert ranges, the Cottonwood and the Chuckawalla Mountains, which separate the Mohave and the Colorado Deserts. To the southward, again, between the Colorado Desert and the coastal region, rise the San Jacinto Mountains. The eastern base of Mount San Jacinto, the highest peak in this range, rests almost directly upon the low depressions of the Colorado Desert (Palm Springs, altitude 137 meters) while its summit, scarcely eight miles distant in an air line, rises with an almost sheer ascent to 3242 meters. South of the San Jacinto Mountains are the less rugged Palomar, Santa Rosa, and Cuiamaca Mountains. This series of mountain ranges divides the deserts from the coastal region, and is one of the principal factors which influence the climate of southern California.

The arid desert country east of the mountains, comprising over one half the entire area of southern California, is separated by the Cottonwood and Chuckawalla Mountains into two distinct divisions, the Mohave and the Colorado Deserts. 


\section{( 303$)$}

The Mohave Desert, which lies to the north of the dividing ranges, is triangular in outline and covers an area of approximately $5 \mathrm{I}, 200$ square kilometers. It is chiefly an arid plateau with an elevation of 300 to 900 meters, but north of our limits is the low depression of Death Valley which is nearly 90 meters below sea level. The broad level expanse is broken here and there by short isolated ranges or "lone mountains," the rocky barren slopes of which, save for their talus bases, rise abruptly from the floor-like plain. Between these elevations are numerous low depressions which have become sinks or "dry lakes." The surfaces of these are frequently crusted over with the deposits of soluble salts, and the margins lined with characteristic saline vegetation.

To the south of the Cottonwood and the Chuckawalla Mountains lies the Colorado Desert, which extends southward along the gulf slope of Lower California, and eastward into southern Arizona and northwestern Sonora. Within the boundaries of California this desert, the area of which occupies a little over I6,000 square kilometers, is principally the dry bed of a large inland sea or lake, with pebble-covered beaches that are still clearly discernible along the base of the surrounding mountains. At one time this depression was a continuation of the Gulf of California, from which it was cut off in comparatively recent times. This separation was accomplished partly, perhaps, by a slight elevation of the land between the vicinity of Yuma and the Cocopa Mountains, but chiefly by the delta formed at the mouth of the Colorado River, which latter carries great quantities of silt. Inward from the gravelly rim of the depression the character of the soil gradually changes from a sandy loam into the heaviest of clays, while the center, now covered by an accidental overflow from the Colorado River, is normally a salt bed several feet in thickness.

On the western or coastal side of the mountains the foot-hills and mountains give way here and there to valleys often of considerable extent. These valleys are mainly very fertile, supporting a luxuriant vegetation wherever water is plentiful, but areas of low alkaline soil, or dry gravelly mesas or washes are frequently interspersed. Along the southern base of the San Gabriel and the San Bernardino Mountains the original floor of the valley has been buried by debris of gravel and coarse sands, washed down by the winter torrents from the steep mountain slopes. Here 
and there, however, isolated hills or elevated mesas, projecting above the talus, remain as indicators of the original sedimentary deposits. This large interior valley is separated from the low valley along the coast of Los Angeles and Orange Counties by the Santa Ana Mountains, and a series of low hills which connect them with the Santa Monica Mountains. North of this last range is the low coastal valley of Ventura County, the only other valley of any considerable area on the western side of the mountains.

\section{CLIMATOLOGY}

\section{General Description}

There is great diversity of climate, due principally to topography, a factor which exerts a marked influence in southern California, since the principal mountain ranges lie transversely to the path of the prevailing winds and storms. As a rule, however, the climate is one of scant precipitation and high temperatures, conditions that become more and more pronounced toward the interior, away from the ameliorating influences of the cool moist sea-breeze. The rainfall is chiefly confined to the winter and early spring months, the dry summer and autumn having almost continual sunshine. Precipitation is greatest in the mountains, with an average annual rainfall in some localities exceeding 100 centimeters, and least in the Colorado Desert, where it is less than 5 centimeters in some sections. Fully as great extremes are found in temperatures. On a winter day, for instance, one may stand among blooming roses or in orange groves laden with ripe fruit, and watch the snow, driven by piercing winds, drifting about the rugged peaks of the neighboring mountains.

The following temperature and rainfall records have been compiled from McAdie's "Climatology of California": 


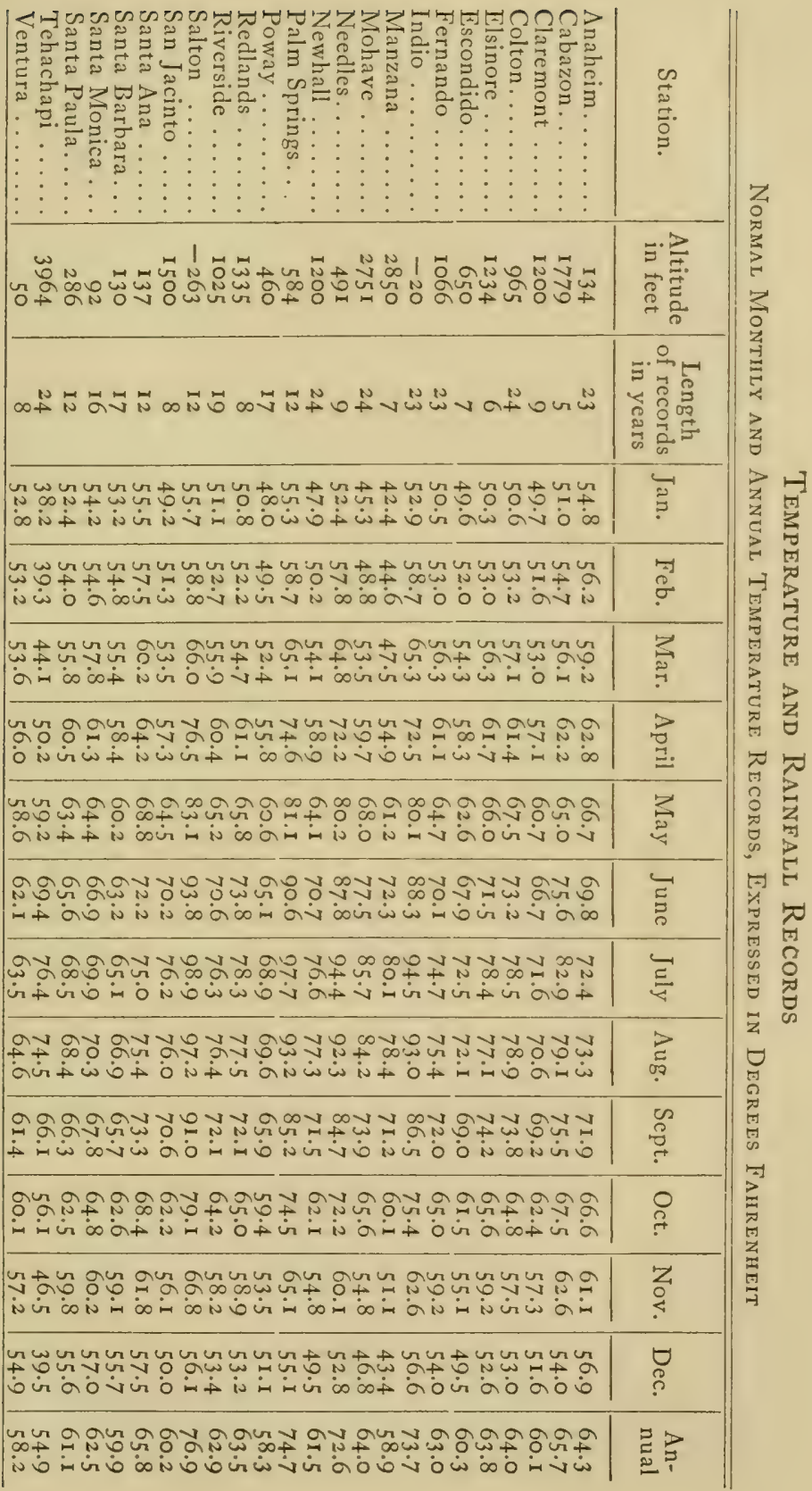




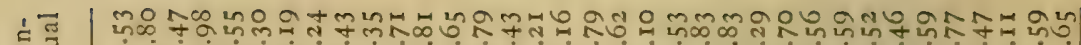

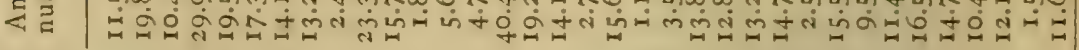
ن |

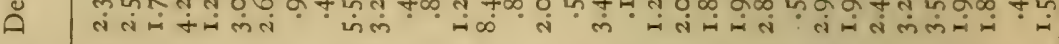

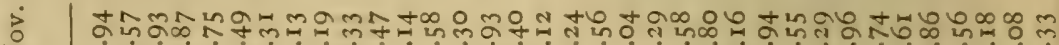
Z | मिं

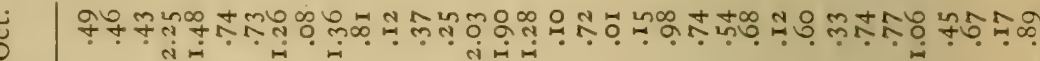

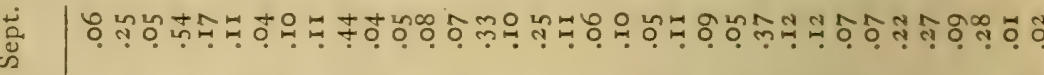

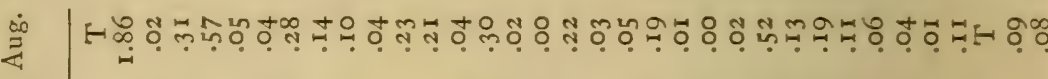

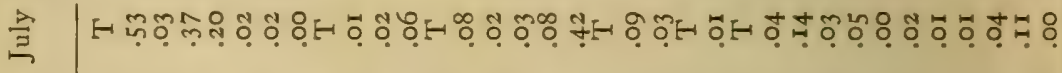

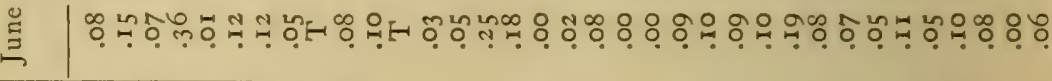

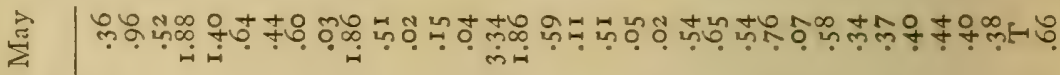

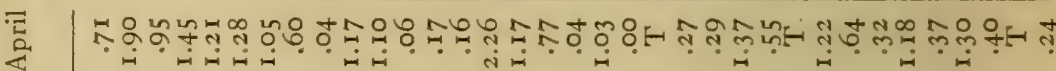

1 का

¿ JरH

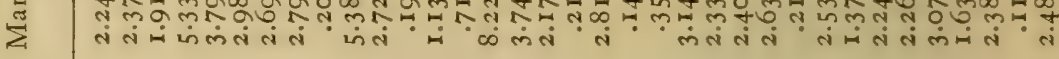

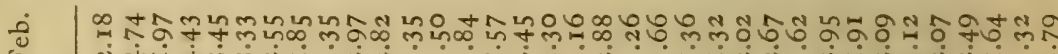

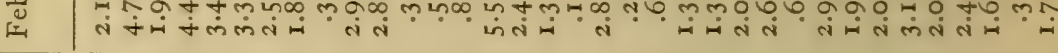

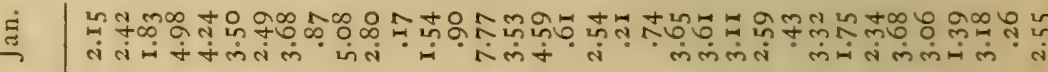

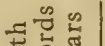

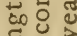

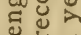

药.

mon

ֶृ

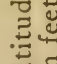

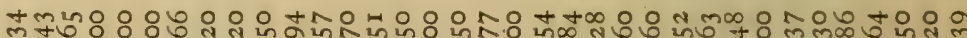
昰.

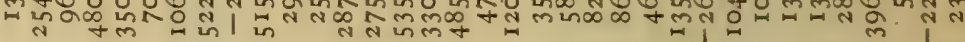

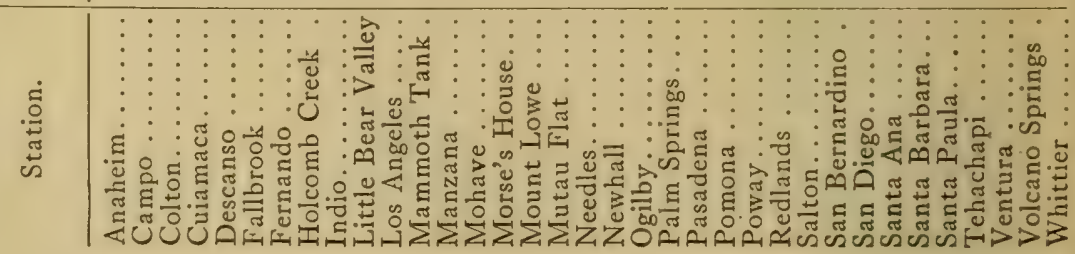


Chart of the Annual Rainfall Records, Classified According to the Phytogeographic Sections

(Each column represents one eighth the actual rainfall)

Deserts, altitude -87 to $9 r 7$ meters, Lower Austral Zone; rainfall $64.2 \mathrm{~cm}$.

Mountains, altitude $I 600$ to 1780 meters, Transition Zone; rainfall $798 \mathrm{~cm}$.

Foothills, altitude 847 to I32I meters, Upper Austral Zone; rainfall 488.7 $\mathrm{cm}$.

Interior valleys, altitude 400 to 454 meters, Lower $\Lambda$ ustral Zone; rainfall 324 $\mathrm{cm}$.

Coastal valleys, altitude Io to 279 meters, Upper Austral Zone; rainfall $340.5 \mathrm{~cm}$.

San Diego district, altitude 10 to 100 meters, Lower Austral Zone; rainfall $238 \mathrm{~cm}$.

\section{PHYTOGEOGRAPHIC FEATURES}

\section{GENERAL DESCRIPTION}

Phytogeographically southern California is separated into three clearly defined floral divisions-the coastal slope, the mountain, and the desert. Each of these divisions has derived its characteristic plants from different floral elements. The species of the coastal slope are principally of Californian origin; the species confined to the mountains, boreal or of boreal ancestry; and those of the deserts, endemic or migrants from the Great Basin, Sonora, or Lower California. To discuss these different floras intelligently it is essential that some general system be followed. Engler's ${ }^{1}$ arrangement has many commendable features, but Merriam's ${ }^{2}$ system of North American life zones has been more completely worked out for this country and is therefore adopted.

An outline of Merriam's life zones for North America north of the tropics is as follows:

Region

Zone

Area

Boreal........... $\left\{\begin{array}{l}\text { Arctic-alpine } \\ \text { Hudsonian } \\ \text { Canadian }\end{array}\right.$

1Engler, A. Syllabus der Pflanzenfamilien, 213-222. 1907.

${ }^{2}$ Merriam, C. H. Life Zones and Crop Zones of the United States. Bull. U. S. Biol. Survey, No. 10. 1898. 


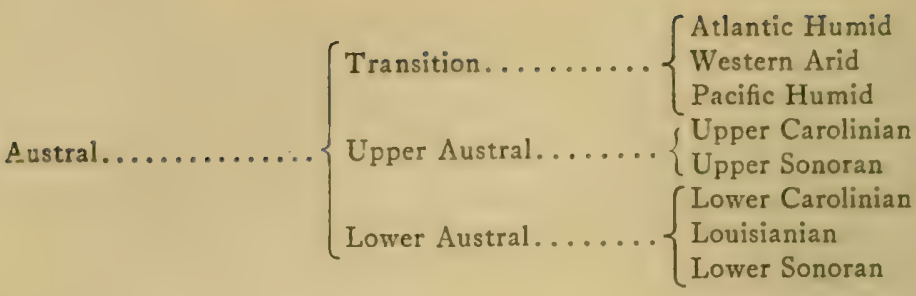

BOREAL REGION

\section{General Description}

In southern California the Boreal Region occupies the uppermost altitudes of the prominent mountain peaks, seldom descending lower than 2550 meters. It is therefore comparatively restricted, appearing only on the following peaks: Pinos, North Baldy, Pine, San Antonio, Sugarloaf, San Bernardino, San Gorgonio, San Jacinto, and Santa Rosa. The region is most extensive in the vicinity of Mount San Gorgonio and Mount San Bernardino, where it covers the high ridges connecting the peaks and the spurs leading from them.

The three zones of the Boreal Region are less clearly defined than in more northerly territories, chiefly because the area covered by it is so limited. The presence of the Arctic-alpine Zone was first noted by $\mathrm{Hall}^{3}$, who discovered three characteristic Alpine species, Carex Preslii, Oxyria digyna, and Ranunculus Eschscholtzii on steep north slopes of Mount San Jacinto near perpetual snow. To this scanty list Parish ${ }^{4}$ has added Arenaria hirta verna and Antennaria alpina from Mount San Gorgonio. The presence even of this small number of truly Arctic-alpine species is of considerable interest, for, as pointed out by Hall and Parish, they mark "the most southern known limit of the Artic flora on the North American Continent."

\section{Canadian Zone}

The two lower zones, the Hudsonian and the Canadian, are inseparable in southern California. Parish suggests that Pinus Murrayana characterizes the Canadian, and Pinus flexilis the

${ }^{3} \mathrm{Hall}, \mathrm{H} . \mathrm{M}$. A botanical Survey of San Jacinto Mountain. Univ. Calif. Publ., Bot. 1: 16. 1902.

'Parish, S. B. Sketch of the Flora of southern ${ }^{-C}$ alifornia. Bot. Gaz. 36: 203-222 and 259-279. 1903. 
Hudsonian, but such a distinction is not tenable, for on Mount San Gorgonio, where the Boreal Region is best developed, both species intermingle from the neighborhood of Dry Lake (altitude 2775 meters) to the very summit. Ascending the mountain from Dry Lake one passes through pure forests of these two pines. Even the floor, which is composed of loose broken granitic rock, is almost bare of vegetation. Continuing upward the trees become fewer and more reduced in stature until it is difficult to walk beneath their gnarled branches. Finally, as the summit is approached, they become prostrate shrubs with such stiff compact branches that one may tramp over them with little difficulty. On the summit of Mount Pinos, where Pinus Murrayana has not been recorded, Pinus flexilis is found intermingling with Abies concolor and other upper Transition species. In fact it is impossible to detect two distinct belts of these two pines on any of the mountains. Notwithstanding the fact, therefore, that there are traces of Arctic-alpine plants, the only logical treatment demands that all the Boreal Region of southern California be placed in the Canadian Zone.

In addition to the localities mentioned there is a fringe of the Canadian Zone on the western borders of Bear Valley, and Bluff Lake. Pinus Murrayana grows rather abundantly here, the lowest altitude (2010 meters) reached by this species in southern California.

The characteristic trees and shrubs are:

\section{Pinus flexilis}

Pinus Murrayana

Populus tremuloides

Salix glaucops
Ribes montigenum

Sericotheca concolor

Phyllodoce Breweri

Sericotheca concolor and Phyllodoce Breweri extend northward through the Sierra Nevada to the southern Cascade Mountains, and to the mountains of western Nevada. All the remaining species extend to the Rocky Mountains, and one, Populus tremuloides, to the northern Atlantic. The geographical distribution of these species demonstrates the intimate relation the flora of this zone bears to that of the more northern parts of North America.

The origin of a boreal flora on these isolated southern mountain peaks is traceable to the influence of the Glacial Period. During that period central and southern California possessed a climate similar to that found to-day in the Puget Sound region. Perpet- 
ual snow and glaciation extended down the mountain slopes to approximately $\mathrm{I} 800$ meters altitude. The Canadian Zone, therefore, probably was as low as 900 meters or even lower, forming an unbroken belt, with the possible exception of San Gorgonio Pass, from the Sierra Nevada to San Pedro Martir Mountain. The receding of the ice and the consequent northern and upward migration of the plants left these isolated remnants stranded on the higher peaks.

From the standpoint of regional distribution it is significant that only one species, Populus tremuloides, extends east of the Rocky Mountains. It argues that an eastern and western area should be recognized.

\section{AUSTRAL REGION}

\section{General Description}

The Austral Region occupies nearly the entire area of southern California, in the midst of which, on the tips of the highest mountain peaks, are situated the small isolated areas of typical Boreal. The three zones of the region are distinctly defined over large areas, but on account of great local variations in climatological conditions, due to slope exposure, sea-breezes, desert winds or other influences, isolated patches of a zone may be found far beyond its normal range.

\section{Transition Zone}

The Transition Zone, which is best characterized by the yellow pine (Pinus ponderosa), includes the principal forested area of the mountains. Its average range of altitude is from 1500 to 2700 meters, but deviations from this, chiefly due to slope exposure, are often considerable.

The forests are principally coniferous with a few scattered oaks, and along streams, poplars, willows, alders and maples. They are usually open and park-like, with a sparsely grass-covered floor, or with growths of low underbrush, which in rocky exposed places often develop into chaparral.

Approximately 50 species of trees and shrubs have been recorded within the Transition Zone, of which the following are characteristic:

Pinus Lambertiana

Pinus ponderosa
Ceanothus integerrimus puberulus Ceanothus Palmeri 
Pinus ponderosa Jeffreyi

Pinus Coulteri

Abies concolor

Heyderia decurrens

* Juniperus occidentalis

* Salix Scouleriana

Quercus Kelloggii

* Castanopsis sempervirens

Ribes nevadensis

Rubus leucodermis

Rubacer velutinus

Cercocarpus ledifolius

Cercis occidentalis

* Ceanothus cordulatus
Cornus Nuttallii

Azalea occidentale

Uva-ursi Parryana

* Uva-ursi patula

Uva-ursi Pringlei

* Leptodactylon Hookeri

Eriodictyon Parryi

Ramona pachystachya

Pentstemon jacintensis

Sambucus mexicana

*Symphoricarpus Parishii

Chrysothamnus stenophyllus

Artemesia tridentata

Tetradymia canescens

The species designated by an asterisk (*) are confined to the upper parts of the Transition and extend into the Canadian Zone.

A study of the geographical distribution of the species found in the Transition Zone shows that about sixty per cent. are limited to California (including San Pedro Martir Mountain) or extend only into the southern part of the Cascade Mountains; fifteen per cent. extend northward along the Coast or the Cascade Mountains of Oregon and Washington; ten per cent. are common to California and the Great Basin, and twelve per cent. occur throughout the Western Arid Area.

To express the phytogeographical conditions of this zone accurately it is evident that the divisions must reckon with the large percentage of purely Californian or endemic species. The simple statement that the flora belongs to the Transition Zone, as is usually the case, or that it is in the Western Arid Area, is misleading, as many of the species are not found in other parts of these divisions. It is essential that the areas recognized by Merriam, and based upon moisture, be divided into sub-areas, which are chiefly the result of a third factor-geographical segregation.

Without undertaking a discussion of the entire Western Arid Area, the California mountains, on account of the large number of endemic genera and species, are recognized as a distinct division of the area. This may be termed the Sierran Sub-area.

The Sierran Sub-area is best characterized by Pinus ponderosa Jeffreyi, Pinus Lambertiana and Heyderia decurrens. Its geographical limits on the north are most satisfactorily defined by 
the Klamath Gap. South of this gap the Sub-area occupies the Transition Zone of the Sierra Nevada and the inner Coast Ranges of central California, and extends through the mountains of southern California to Mount San Pedro Martir.

In the Sierra Nevada the Transition Zone is fairly continuous, extending almost unbroken from the north Coast Ranges around the head of the Sacramento Valley, and southward along the western slopes of the Sierra Nevada. The southern inner Coast Ranges and the mountains of southern California, on the other hand, are composed of isolated ranges. Hence great gaps occur in the Transition Zone of these ranges, which form barriers to the migration of species. Each of these sections is usually represented by several peculiar species, while others are conspicuous by their absence. The Sierran Sub-area separates, therefore, into three natural divisions, the Sierra Nevada District, the South Coast Range District, and the San Bernardino District. The latter includes the Transition Zone of the San Gabriel and San Bernardino ranges, and the mountains southward to San Pedro Martir. In this district there are several endemic species, such as Acer bernardinum, Ceanothus integerrimus puberulus, and Ceanothus Palmeri, while many of the species common in the northern districts are absent.

\section{Upper Austral Zone}

General description. - The Upper Austral Zone in southern California is represented wholly by the Upper Sonoran Area, which includes two distinct sections, the coastal slope and the piñon and juniper belts of the desert slopes of the mountains. The characteristic plants of these two sections represent two different floral elements. The coastal slope species are predominantly Californian, while many of those on the desert slopes belong to the Great Basin element.

Coastal slope.-The coastal slope of southern California is separated from the more northern parts of the Californian Subarea ${ }^{5}$ along the seaboard by Point Conception. The coast to

'The California Sub-area, which is equivalent to Engler's "Innerkalifornische" zone of the "Westamerikanische Wüsten- und Steppenprovinz," is that part of the Upper Sonoran Area which lies west of the Sierra Nevada divide, and extends from southern Oregon to northern Lower California. The name "intramontane" has been applied to this region, but it is best 20 restrict that term to the floral district of the sub-area which lies between the Sierra Nevada and the Coast Ranges of central and northern California. "Cismontane" as used by Parish $\left(l . c_{0}\right)$ includes parts of two zones, which seems illogical. 
the southward of this promontory turns directly eastward for I 25 kilometers or more, paralleling the cross ranges which lie only a few miles distant. The coastal country is therefore protected from the northwest coast winds, and its warm southern slopes form a striking contrast to the cold bleak wind-swept mesas and hills about the promontory. A natural barrier is thus formed where a large number of species meet their southern or northern limits.

South of Point Conception the entire coastal slope below the Transition Zone belongs to the Upper Sonoran, except the interior valleys and the southwestern part of San Diego County which are Lower Sonoran.

Within this area, which we shall term the Southern California District, are over roo species of trees and shrubs. A study of the geographical distribution of these species shows that only four extend eastward as far as the Rocky Mountains, less than ten per cent. north to the Columbia River, and about the same number east to the Great Basin and Arizona. Nearly all the remaining species, or fully two thirds of the entire number are confined to the California Sub-area, and of these about forty are chiefly confined to the Southern California District.

The most characteristic species of the Southern California District is Pseudotsuga macrocarpa. The geographical limits of this conifer almost coincide with those of the district. It does not extend northward beyond the Santa Ynez Mountains, nor beyond Fort Tejon in the mountains connecting with the Sierra Nevada. It is confined, however, to the upper altitudes, extending even into the Transition Zone.

The following trees and shrubs are characteristic of the Southern California District, being almost or wholly confined within its boundaries:

Pseudotsuga macrocarpa

Juglans californica

Eriogonum cinereum

Eriogonum fasciculatum foliolosum

Atriplex Breweri

* Clematis pauciflora

Odostemon Nevinii

Ribes indecorum

Grossularia amara
* Ceanothus Orcuttii

Ceanothus megacarpus

Ceanothus crassifolius

Vitis Girdiana

Malacothamnus fasciculatus

Malacothamnus Nuttallii

Styrax californica flavescens

Leptodactylon californicum glandulosum

* Eriodictyon crassifolium 


\section{(3I4)}

Grossularia hesperia

Grossularia Parishii

* Adenostoma sparsifolium

Rosa Aldersonii

* Xylothermia montana tomentosa

Lupinus longifolius

Lupinus Hallii

Rhamnus pilosa

Ceanothus spinosus

Ceanothus divaricatus eglandulosus
Trichostema Parishii

Sphacele fragrans

* Diplacus longiflorus

Diplacus puniceus

Pentstemon cordifolius

* Penstemon ternatus

Pentstemon antirrhinoides

Lonicera subspicata denudata

Ericameria cuneata spathulata

Ericameria Parishii

Baccharis Plummerae

\section{Ceanothus oliganthus}

The species designated by an asterisk $\left(^{*}\right)$ are restricted to the southern part of the district.

The general character of the vegetation is typical of a warm temperate climate which possesses moist cool winters and hot dry summers. The predominant plants are evergreen xerophyllous shrubs with small thick leathery leaves of a dull or grayish-green color. They are invariably stiff compact growers, forming impenetrable thickets that spread over the mountainsides in almost unbroken masses for many miles.

The diversity of the flora, however, is considerable. The proximity of the sea and the irregularities of the topography, together with the resultant climatic conditions, are factors that have aided in the development of several sub-districts with distinctive floral features. Three of these floral sub-districts are recognized: the Littoral, the Coastal, and the Interior. The first of these subdistricts is the territory the within immediate influence of the sea, the second comprises the fog belt, and the third the chaparral belt of the interior mountains and foothills which are more or less cut off from the direct influence of the sea-breeze by hills or low mountains. Where passes or other connections exist between the Interior and the Coastal Sub-district the floral changes are gradual and difficult to separate.

The Littoral Sub-district is confined to the immediate proximity of the sea, and is composed of four formations: the beach, the sand-dune, the salt-marsh, and the bluff. The number of shrubby plants wholly limited to this sub-district is small, Eriogonum parvifolium, Lupinus Chamissonis, and Ericameria ericoides on the sand-dunes, and Atriplex Breweri on the bluffs and edges of 
salt-marshes being the complete list. ${ }^{6}$ Of these strictly maritime species, Eriogonum parvifolium extends northward to Monterey, and Atriplex Breweri to Santa Barbara. The other species are also confined to the California coast, but extend farther northward into northern California.

The Coastal Sub-district comprises the valleys and rolling hills along the coast, and the coast slope of the foothills and mountains which separate them from the interior valleys. Its inland boundary extends along the southern slope of the Santa Ynez Mountains, the coast slope of the mountains of Ventura County, and southward through the San Fernando and Santa Monica Mountains to the Santa Ana Mountains, thence along the western slope of the Palomar Mountains where it blends with the Interior Subdistrict.

The principal plant formations of this area are the mesa and rolling hills, the alluvial, the oak-grove, the canyon, and the chaparral. The mesas and rolling grassy hills are characterized chiefly by the absence of woody plants rather than by any peculiar species. Along the inner boundary of this formation and merging with the Interior Sub-district are park-like groves of oaks. North of the Santa Monica Mountains, along their northern base, and in the Simi, Newhall and Ojai Valleys handsome trees of Quercus lobata abound. This species does not extend south of the Santa Monica Mountains, but its place south of this range is taken by Quercus Engelmannii which, together with Quercus agrifolia, covers considerable area about Pasadena, Santa Anita, and Fallbrook.

The following trees and shrubs are mostly confined to the Coastal Sub-district:

Myrica californica

Juglans californica

Quercus lobata

Quercus Engelmannii

Grossularia speciosa

Grossularia amara

Sericotheca franciscana

Lupinus longifolius
Malacothamnus Nuttallii

Ceanothus spinosus

Ceanothus sorediatus

Ceanothus oliganthus

Ceanothus megacarpus

Arbutus Menziesii

Trichostema lanatum

Ramona niveum

'In addition to these true shrubs there are a number of suffrutescent perennials that are also confined to this sub-district. Among these may be mentioned Cheiranthus suffutescens, Sphacrostigma viridescens, Batis maritima, and Salicornia ambigua. 
Polygala californica

Acer californicum

Lithraea laurina
Lonicera Ledebourii

Baccharis pilularis

Baccharis Plummerae

A large percentage of these species, which are chiefly confined to the northern part of the sub-district, are common in northern California. They simply reach their southern limit within this sub-district. In this connection the influence of the Santa Monica Mountains should not be passed by unnoticed. This cross range, although seldom reaching a higher altitude than 750 meters, exerts a marked influence on the northern and southern distribution of plants along the coast. The two oaks, Quercus lobata and Quercus Engelmannii, are notable examples of species that are checked by this range in their northerly or southerly distribution. Several northern shrubs, such as Myrica californica and Baccharis pilularis, do not occur south of this range.

The Interior Sub-district occupies the foothills and the typical chaparral of the interior mountains which are shut off from the direct influence of the sea-breeze by hills or low mountains. The western boundary is outlined by the Coastal Subdistrict, and its inland by the Transition Zone of the higher mountains, or by the deserts in the lower mountains and passes. This sub-district extends from the Liebre Mountains southeastward along the coastal slope of the San Gabriel, the San Bernardino, the San Jacinto, and the Cuiamaca mountains.

The chaparral, of which the sub-district is almost wholly composed, is separated into several altitudinal belts. These altitudinal floral changes are very evident to one ascending any of the mountain trails. Along the base of the mountains, sometimes extending up their slopes several hundred feet and out over the footslopes, is a belt intermediate between the Upper and Lower Sonoran. Here the prevailing plants are Ramona stachioides, Eriogonum fasciculatum foliolosum and Senecio Douglasii. Ascending the steep mountain slopes one passes in to the typical chaparral. Adenostoma fasciculatum prevails through the lower altitudes in the eastern part of the San Gabriel Mountains, and in the San Bernardino andt he San Jacinto Mountains, but on the Mount Wilson trail, which is intermediate between the Coastal and the Interior Sub-districts, Quercus dumosa and Ceanothus crassifolius are the predominating species. Further up the slopes these species gradually give way to others, of which Ceanothus divaricatus 
eglandulosus, Uva-ursi tomentosa, and, in the San Bernardino Mountains, Uva-ursi pungens, are perhaps the most characteristic. Pseudotsuga macrocarpa grows with these species, especially on the north slopes. This tree becomes more abundant at higher altitudes and extends into the lower part of the Transition Zone.

In the canyons, Quercus chrysolepis, Acer macrophyllum and Umbellularia californica seldom descend lower than 750 meters; but Alnus rhombifolia often follows living streams into the edges of the valleys. Platanus racemosa is mostly confined to the lower altitudes, and occurs on the canyon floors, often following the washes well out into the valleys.

The following trees and shrubs are mainly restricted to the Interior Sub-district:

Pseudotsuga macrocarpa

Ribes indecorum

Adenostoma sparsifolium

$X y$ lothermia montana tomentosa

Lupinus Hallii

Ceanothus divaricatus eglandulosus
Ceanothus crassifolius

Uva-ursi pungens

Trichostema Parishii

Pentstemon ternatus

Pentstemon antirrhinoides

Ericameria Parishii

Desert slopes.-The Upper Sonoran Area on the desert slopes of the mountains is commonly called the piñon and juniper belts, the two conifers, Pinus monophylla and Juniperus californica being the most characteristic species. The piñon occurs in the upper altitudes of the zone (I200-I800 meters). The juniper, on the other hand, occupies the lower altitudes (900-I 200 meters), and along the lower edges of the belt mingles with the yuccas and other shrubs characteristic of the Lower Sonoran. ${ }^{7}$ In the Providence Mountains Juniperus utahensis replaces Juniperus californica. This is the only locality where this species enters into our territory, but in the Panamint Mountains it also replaces Juniperus californica, and extends from there eastward over southern Nevada and Utah. Each of these species may be considered as representing a distinct floral district.

Several trees and shrubs which belong properly to the Intramontane district penetrate through Tejon Pass and extend in a

7The juniper belt is retained in the Upper Sonoran with reluctance, for over a large part of the belt the associating species are predominantly Lower Sonoran. On the coastal slope if we found the juniper at all we should expect it in the Upper Sonoran, if it actually belongs in that zone, but instead it occurs only in the Lower Sonoran of the interior valleys. 
narrow belt along the western slope of Antelope Valley. The normal flora of the desert slopes is modified in this section by the presence of such species as Pinus Sabiniana, Ouercus Douglasii, Grossularia quercetorum and Aesculus californica.

Along the Mexican Boundary a number of Peninsular species enter the flora in the piñon belt. Of these Pinus quadrifolia is the most noteworthy. This nut pine, which almost entirely replaces Pinus monophylla a few miles below the international boundary, occurs sparingly as far north as the Santa Rosa Mountains.

The following are the characteristic Upper Sonoran trees and shrubs of the desert slopes:

* Pinus monophylla

* Pinus quadrifolia

Juniperus californica

Juniperus utahensis

Ephedra viridis

*Quercus Alvordiana

* Quercus Dunnii

* Quercus turbinella

Eriogonum fasciculatum polifolium

* Eriogonum Heermanii

*Odostemon Fremontii
Isomeris arborea globosa

* Kunzia glandulosa

* Rhamnus cuspidata

* Ceanothus vestitus

Malacothamnus Fremontii

* Fremontodendron californicum Fraxinus velutinus

Fraxinus anomala

Diplacus aridis

Stenotopsis interior

The species designated by an asterisk $\left(^{*}\right)$ are confined to the upper or piñon belt.

\section{Lower Austral Zone}

General description.-The Lower Austral Zone in southern California is represented by the Lower Sonoran Area. It includes all of the desert regions below the juniper belt, and protrudes through the lower passes into the hot interior valleys of the coastal slope. It also extends northward along the coast of Lower California to the vicinity of San Diego.

Three floral elements enter into the composition of the Lower Sonoran in southern California, the Great Basin, the Sonoran, and the Peninsular. In the Mohave Desert many of the characteristic species are of the Great Basin element, in the Colorado Desert the Sonoran and the Peninsular species predominate, and at San Diego the Peninsular. Unfortunately the Lower Sonoran Area has not been sufficiently explored to warrant its division into sub-areas. Each of the southern California sections 
of the zone will be discussed, therefore, without an attempt to assign them to definite floral districts.

Interior valleys.- In the San Fernando, the San Bernardino, and the San Jacinto Valleys, the fan-like footslopes that spread over the valleys from the bases of the steep mountain slopes, and the dry washes leading from the mouths of the canyons give rise on their semi-arid gravelly slopes to a low shrubby type of vegetation resembling that of the desert in its xerophytic habit. The upper parts of the footslopes, as has been previously stated, are intermediate between the Upper and the Lower Sonoran, but the dry washes produce a typical Lower Sonoran flora, that often spreads over the greater part of the footslopes.

Following is a list of characteristic Lower Sonoran trees and shrubs of the interior valleys:

Salix vallicola

Populus Fremontii

* Strombicarpus pubescens

* Prosopis glandulosa

Opuntia bernardina

Opuntia Covillei

* Chilopsis linearis
Gutierrezia divergens

Ericameria pinifolia

* Encelia farinosa

Viguiera Parishii

Bebbia juncea

Lepidospartum squamatum

Tetradymia comosa

The species designated by an asterisk (*) occur only in the eastern end of the San Bernardino Valley or in the San Jacinto Valley, and of these only Encelia farinosa is common.

San Diego district.-A large number of peninsular species of shrubs and herbaceous plants extend into southwestern San Diego County which give a floral aspect quite unlike that of other parts of the coastal slope.

The following is a list of peninsular or desert species recorded from the vicinity of San Diego:

Ephedra californica

Yucca mohavensis

Atriplex canescens

Isomeris arborea

Prosopis velutina

Cneoridium dumosum

Acalypha californica

Tricherostigma miserum

Simmondsia californica

Adolphia californica
Opuntia prolifera

Opuntia californica

Lycium Richii

Lycium Andersonii Wrightii

Lycium californicum

Hymenoclea monogyra

Gaertneria chenopodifolia

Iva Hindsiana

Viguiera laciniata 
In addition to the typical Lower Sonoran species there are a number of other shrubby species peculiar to the San Diego region which are often the principal components of the chaparral. These species are: Cercocarpus minutiflora, Adenostoma fasciculatum obtusifolium, Ceanothus verrucosus, Xylococcus bicolor, and Comarostaphylis diversifolia. Pinus Torreyana is also restricted to this, with the exception of a small grove on Santa Rosa Island.

Mohave Desert.-The Lower Sonoran Area occupies nearly the entire area of the Mohave Desert, only in the upper altitudes of the mountains is it replaced by the juniper and piñon belts of the Upper Sonoran. Wherever the soil conditions are favorable Covillea tridentata predominates. This shrub, commonly known as the "creosote bush," is the most characteristic species of the entire Lower Sonoran Area, at least in the arid parts; but, on account of its wide range and its association in the various regions with markedly different floral elements, it cannot be utilized in segregating phytogeographical districts.

Along the upper edges of the Covillea belt, and often extending into the edges of the juniper belt, are a number of characteristic desert shrubs, such as Grayia spinosa, Tetradymia spinosa, Tetradymia stenolepis, Amygdalus Fremontii and Adelia neo-mexicana. Associated with these is the tree yucca (Cleistoyucca arborescens), locally known as the "Joshua tree." The great stretches of this desert yucca that spread over the gradually sloping plains resemble immense orchard tracts, and form a prominent feature of the landscape.

The following Lower Sonoran trees and shrubs have been recorded in the Mohave Desert within the limits of our territory:

* Ephedra nevadensis

* Ephedra californica

* Yucca mohavensis

Cleistoyucca arborescens

* Populus Fremontii

* Salix vallicola

* Salix argophylla

Eriogonum Plumatella

* Atriplex lentiformis

* Atriplex polycarpa

* Atriplex confertifolia

Atriplex Parryi
* Echinocactus Lecontei

* Echinocactus polycephalus

Menodora spinescens

Adelia neo-mexicana

Ramona pilosa

Ramona capitata

* Lycium Cooperi

Lycium Andersonii

Salazaria mexicana

* Chilopsis linearis

* Hymenoclea Salsola

Gaertneria eriocentra 
* Atriplex hymenelytra

* Atriplex canescens Atriplex Torreyi

Grayia spinosa

* Eurotia lanata

* Allenrolfia occidentalis

Sarcobatus vermiculatus

Lepidium Fremontii

* Isomeris arborea

*Isomeris arborea globosa

* Isomeris arborea angustata

Fallugia paradoxa

Cowania Stansburiana

* Coleogyne ramosissima

Kunzia glandulosa

Amygdalus Fremontii

* Strombocarpus pubescens

* Prosopis glandulosa

* Krameria parvifolia

Parosela arborescens

* Parosela californica

Parosela Fremontii

Parosela Saundersi

* Covillea tridentata

*Thamnosma montanum

* Opuntia ramosissima

* Opuntia Bigelovii

* Opuntia acanthocarpa

* Opuntia echinocarpa

* Opuntia Covillei

* Opuntia chlorotica
* Gaertneria dumosa

* Hofmeisteria pluriseta

* Coleosanthus atractyloides

Coleosanthus incana

* Coleosanthus linifolia

* Coleosanthus desetorum

Coleosanthus Knappiana

Gutierrezia lucida

* Acamptopappus sphaerocephalus

*Stenotopsis interior

Ericameria monactis

Acamhiacyris Fremontii

* Chrysothamnus teretifolius

Chrysothamnus mohavensis

* Chrysothamnus occidentalis

* Baccharis Emoryi

* Baccharis sergilioides

* Baccharis glutinosa

* Pluchea sericea

* Bebbia juncea aspera

* Viguiera Parishi

* Encelia actoni

* Encelia frutescens Artemesia Parishii

* Lepidospartum squamatum

* Peucephyllum Schottii

Tetradymia glabrata

Tetradymia stenolepis

Tetradymia spinosa

The species designated by an asterisk $\left(^{*}\right)$ also occur in the Colorado Desert.

Colorado Desert.-Covillea is also the predominant plant over the dry mesas of the Colorado Desert. Above this belt is an area corresponding to the yucca belt of the Mohave Desert, but comprising a very different group of plants, ${ }^{8}$ of which Agave deserti is the most characteristic.

8Parish, Bot. Gaz. 36: 222. 1903: 
In addition to the species common to both deserts the following are found only in the Colorado Desert:

$\begin{array}{ll}\text { Neowashingtonia flamentosa } & \text { Olneya Tesota } \\ \text { Nolina Parryi } & \text { Condalia Parryi } \\ \text { Prosopis velutina } & \text { Foquieria splendens } \\ \text { Acacia Greggii } & \text { Ramona Vaseyi } \\ \text { Parkinsonia aculeata } & \text { Beloperone californica } \\ \text { Parkinsonia microphylla } & \text { Gaertneria ilicifolia } \\ \text { Cercidium Torreyana } & \text { Coleosanthus frutescens } \\ \text { Krameria Grayi } & \text { Gutierrezia bracteata } \\ \text { Parosela Emoryi } & \text { Ericameria brachylepis } \\ \text { Parosela Schottii } & \text { Baccharis sarothroides } \\ \text { Parosela spinosa } & \text { Encelia farinosa }\end{array}$

A study of the geographical distribution of the species not common to both deserts shows that the Mohave Desert species are of the Great Basin element, most of them being common to southern Nevada, southern Utah and northern Arizona, and that the species restricted to the Colorado Desert are of southern origin, and extend into Lower California, southwestern Arizona and northwestern Sonora.

\section{EXPLANATION OF PLATES}

\section{Plate A}

Relief map of California, from the original model by N. F. Drake. Published through the courtesy of the Department of Geology of Leland Stanford Jr. University.

\section{Plate B}

Dry Lake, San Bernardino Mountains, altitude 3180 meters, showing a pure forest of Pinus Murrayana and Pinus flexilis. Canadian Zone.

\section{Plate C}

Juniperus occidentalis, Bear Valley, San Bernardino Mountains, altitude 2230 meters. Transition Zone.

\section{Plate D}

Open park-like forest of Pinus ponderosa Jefreyi, Mount Pinos, altitude 2300 meters. Transition Zone.

\section{Plate E}

Pseudotsuga macrocarpa intermingling with the chaparral, Topatopa Mountains, altitude 1800 meters. Upper Austral Zone.

\section{Plate F}

Alnus hombifolia, Waterman Canyon, San Bernardino Mountains, altitude about 1200 meters. Upper Austral Zone. 


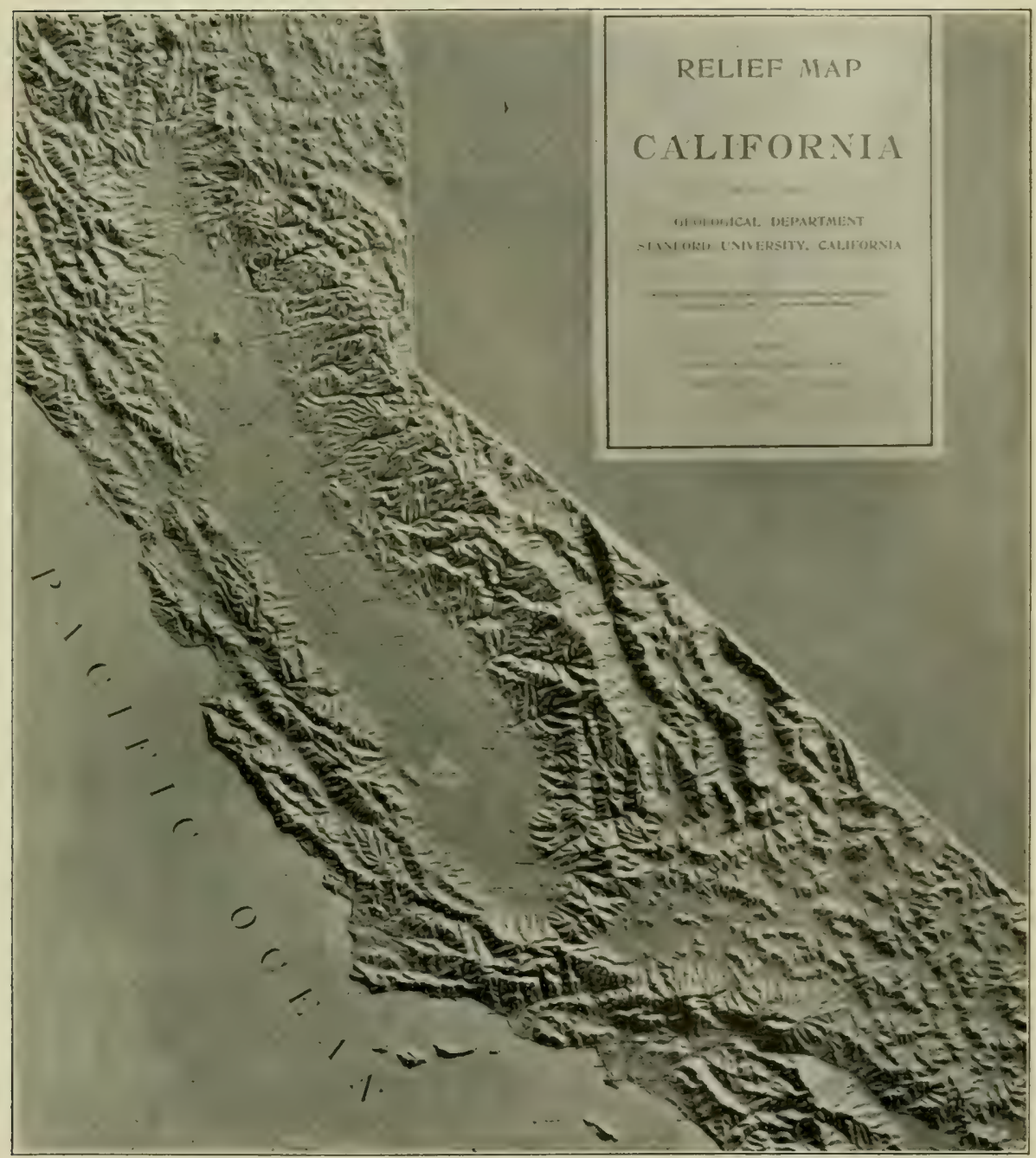

RELIEF MAP OF CALIFORNIA. 



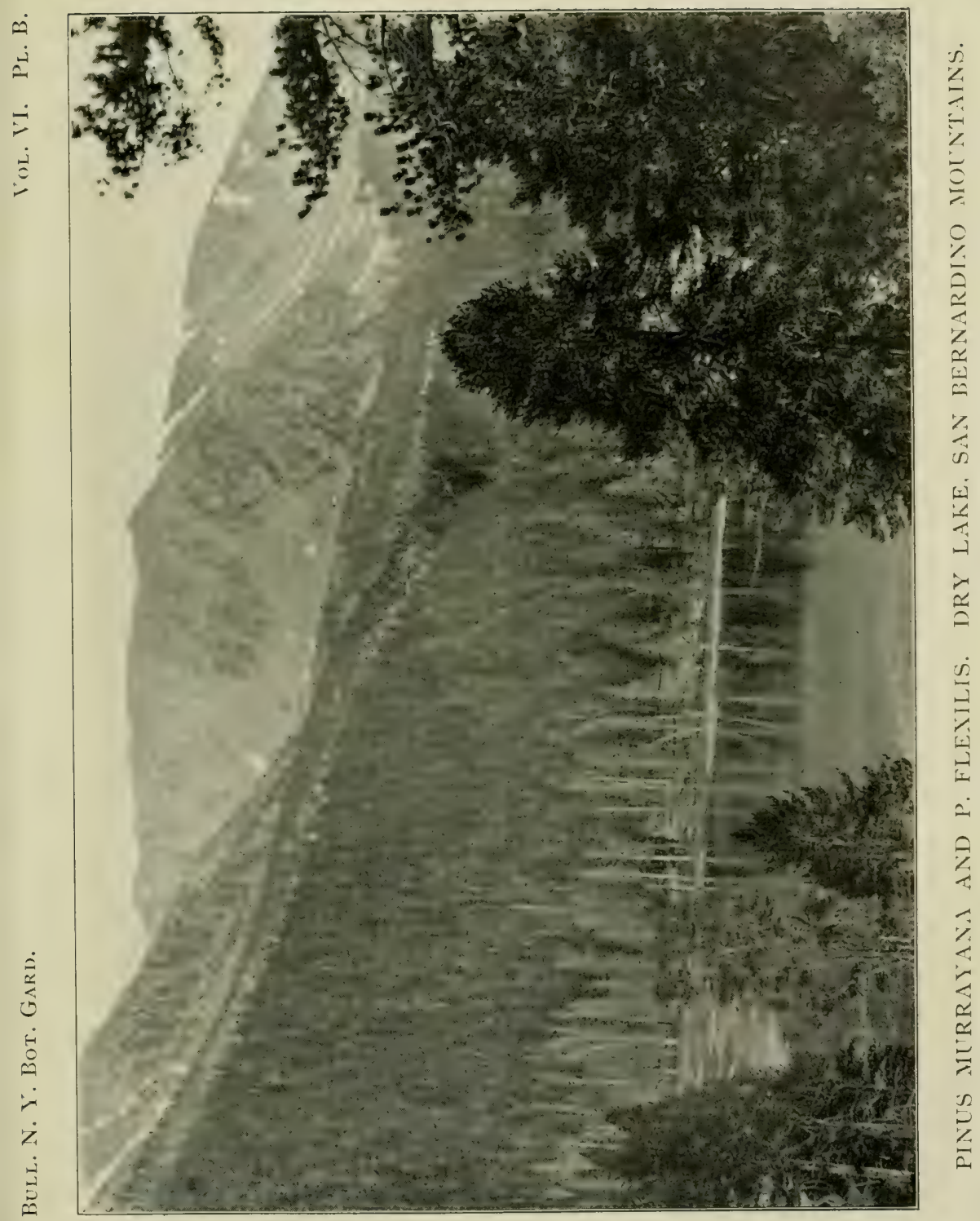





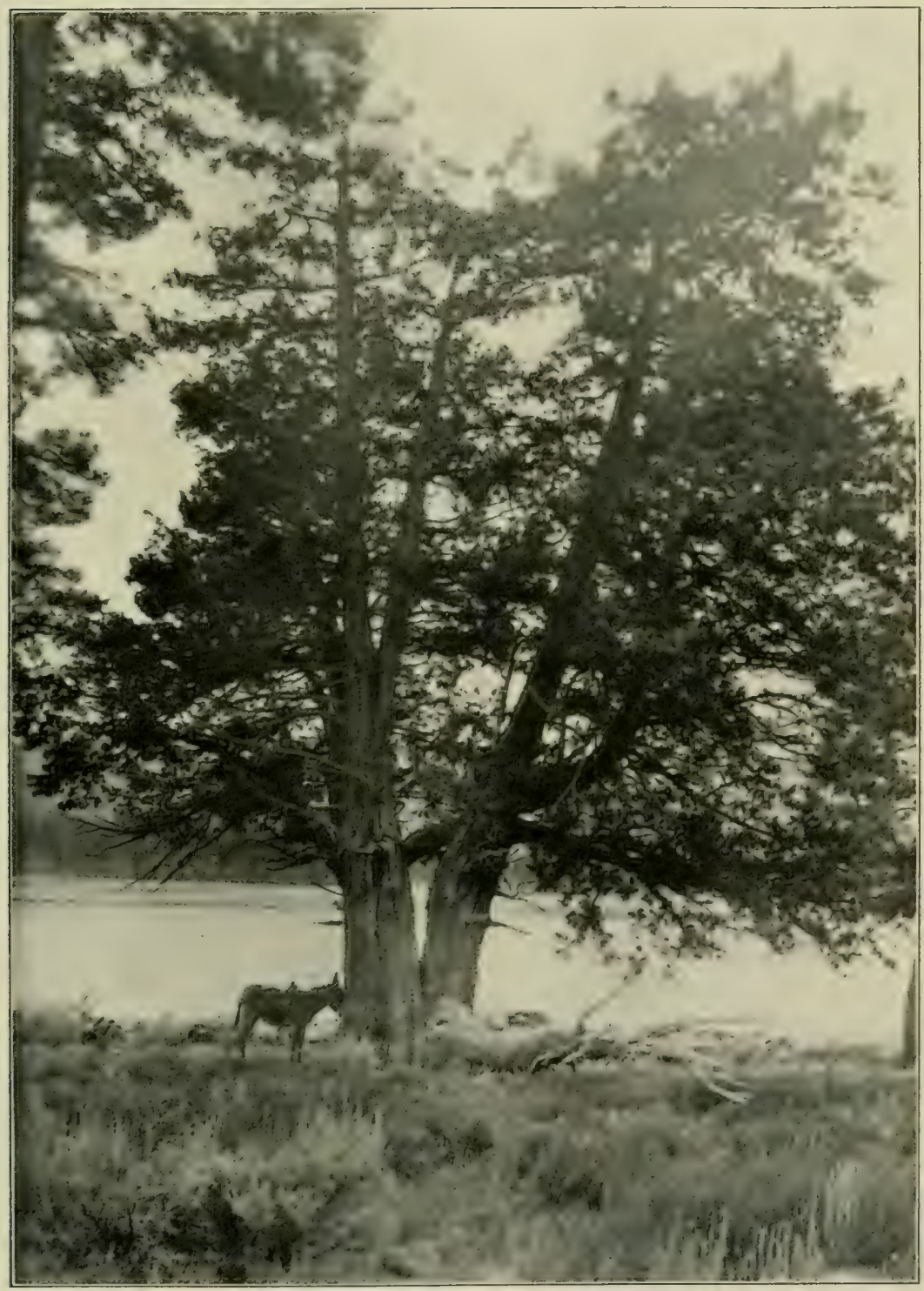

JUNIPERUS OCCIDENTALIS. BEAR VALLEY, SAN BERNARDINO MOLNTAINS. 



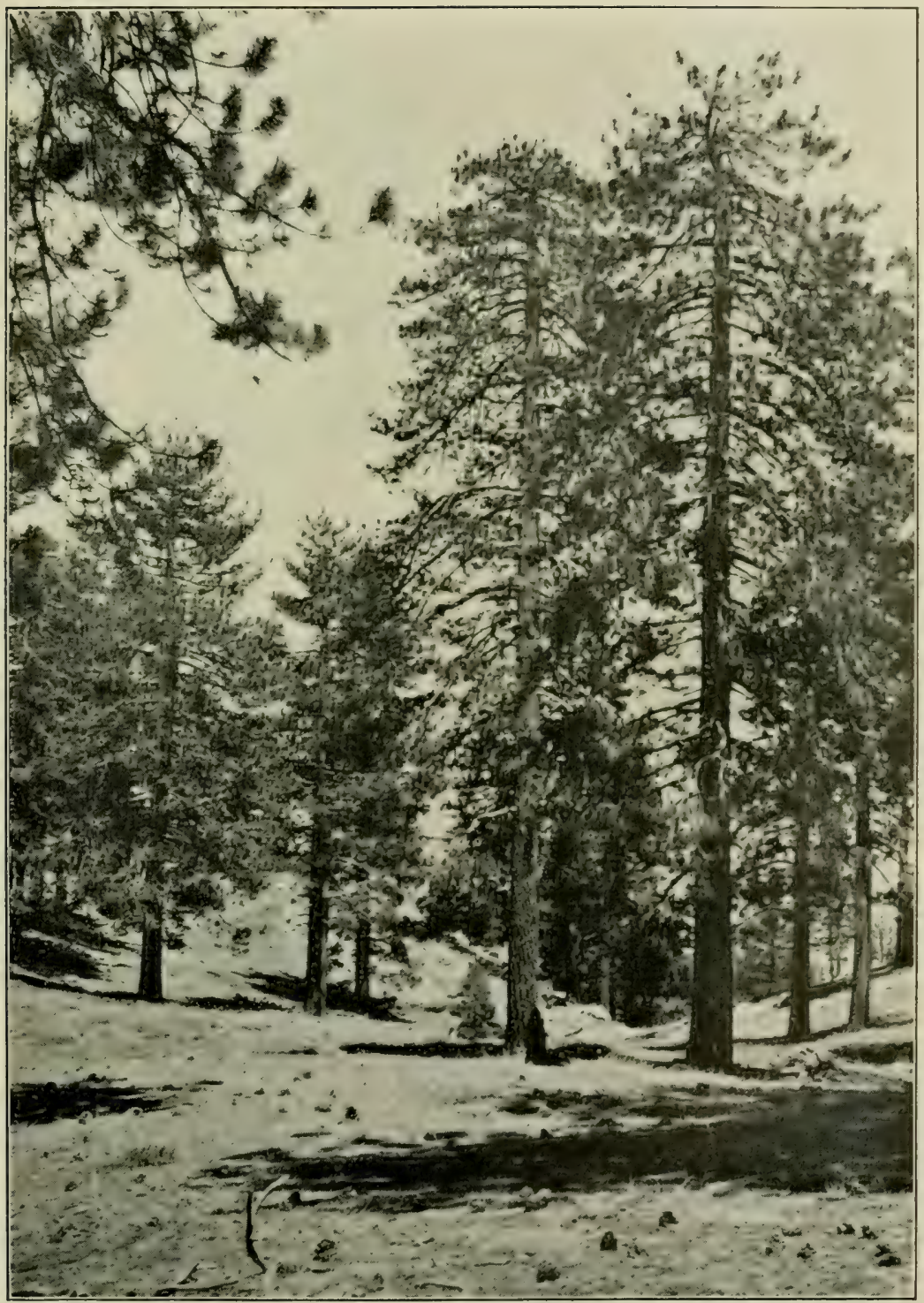

PINUS PONDEROSA JEFFREYI. MOUNT PINOS. 



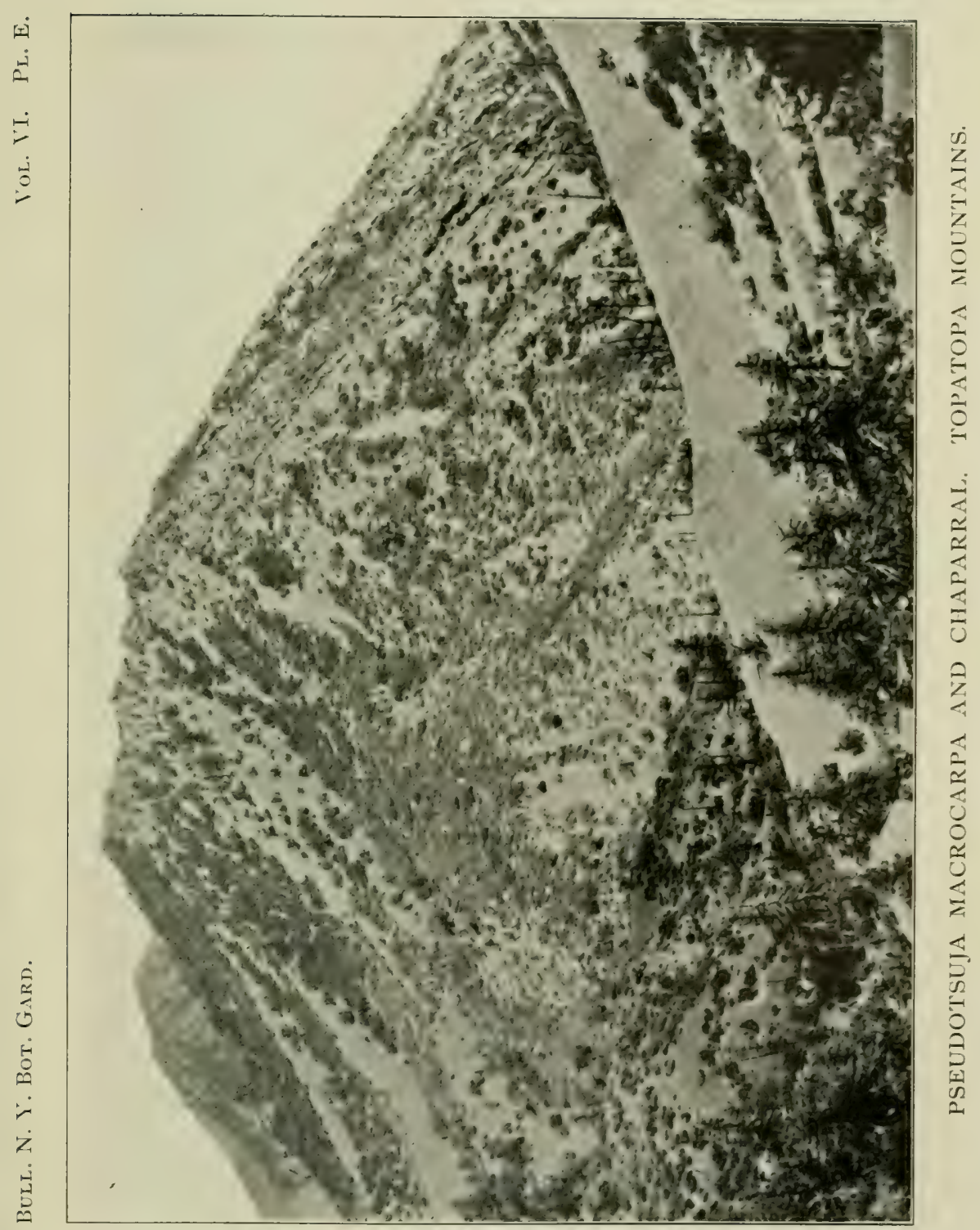




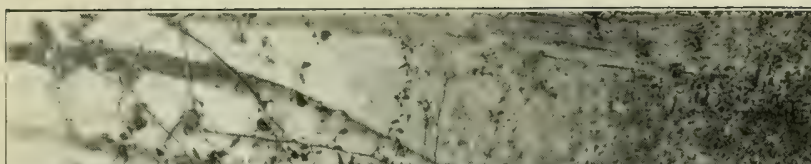

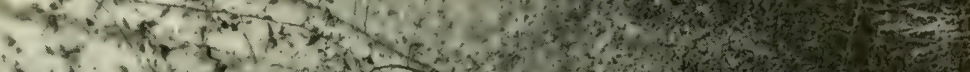

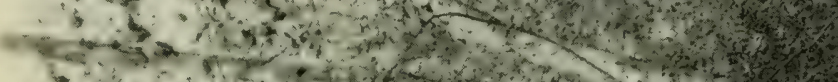

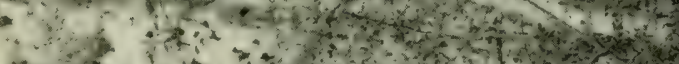

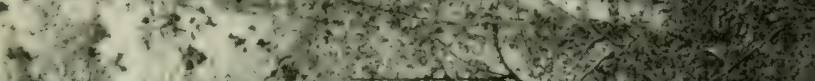

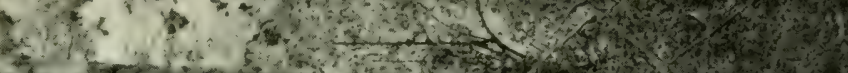

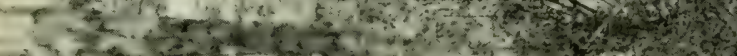

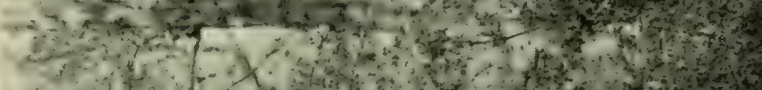

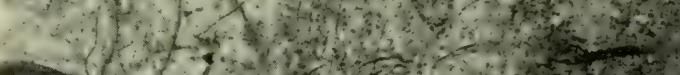

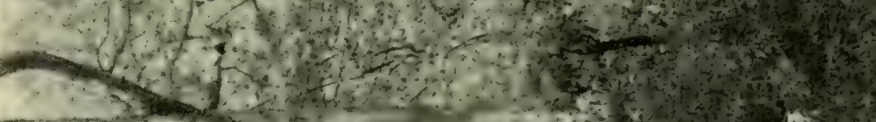

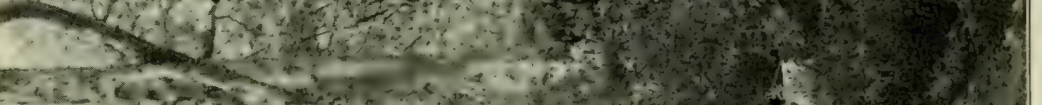

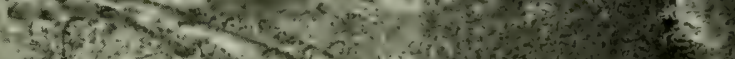

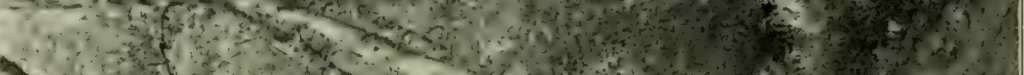

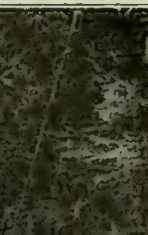

放

$\underset{\pi}{2}$

\%

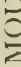

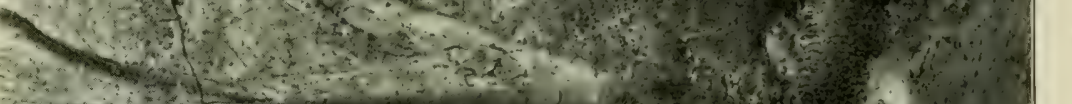

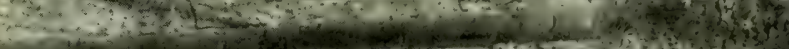

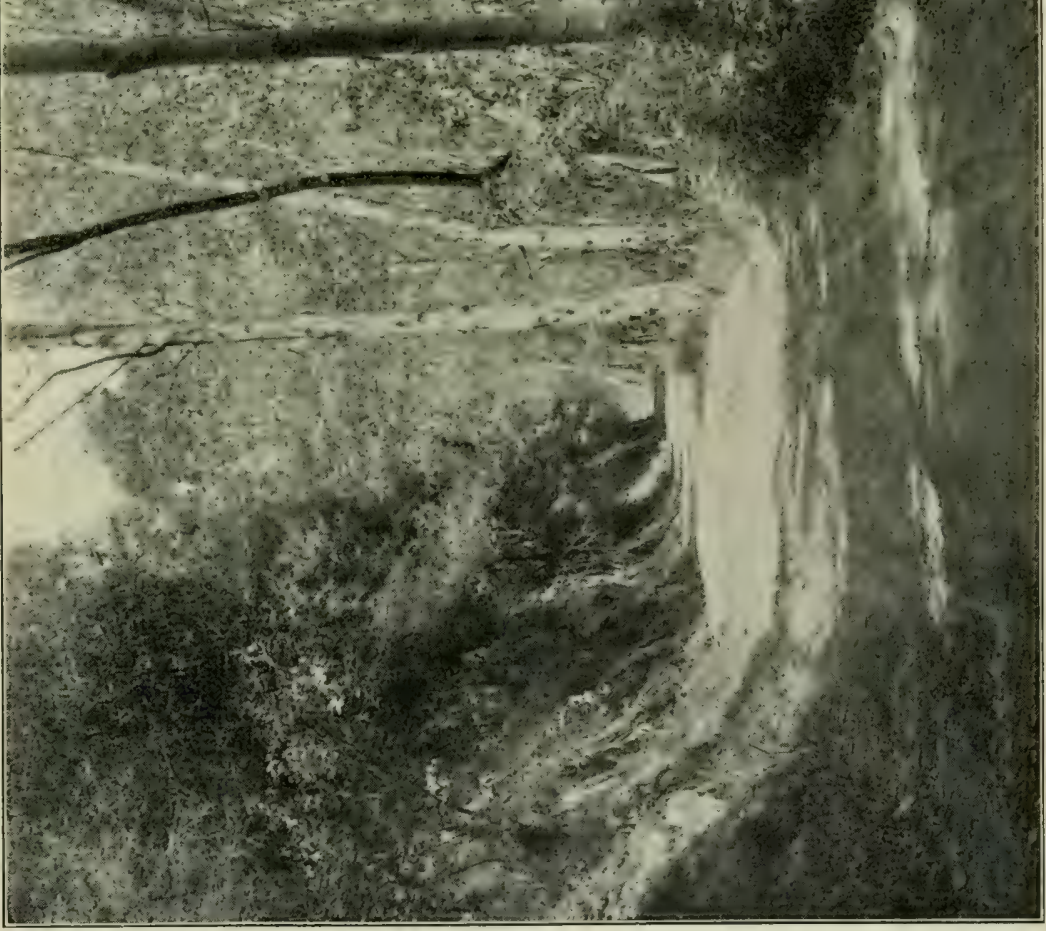

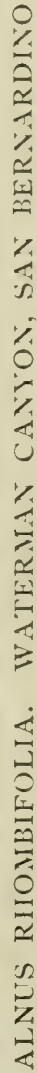





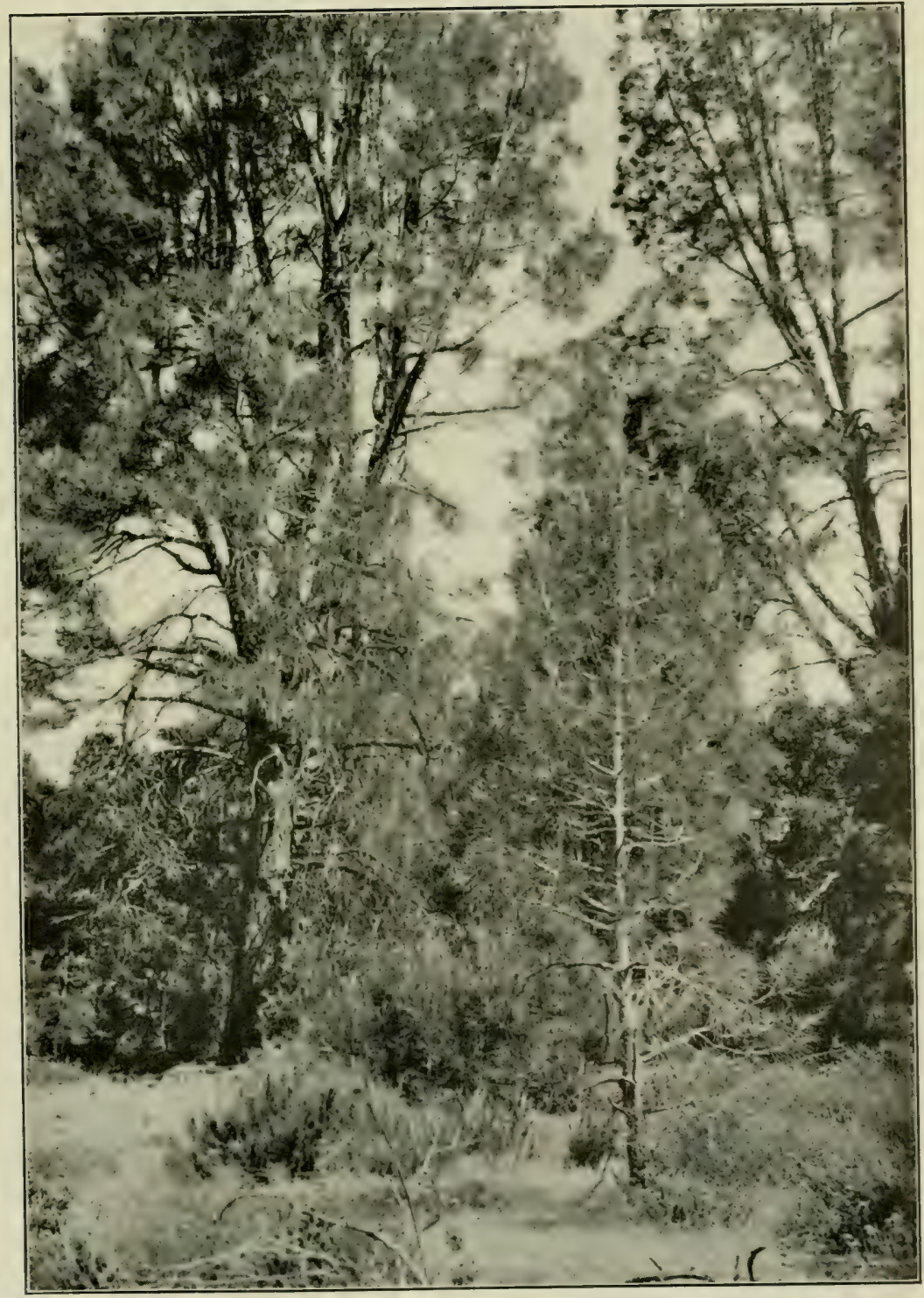

PINUS SABINIANA. OAKGROVE CANYON, LIEBRE MOLNTAINS. 



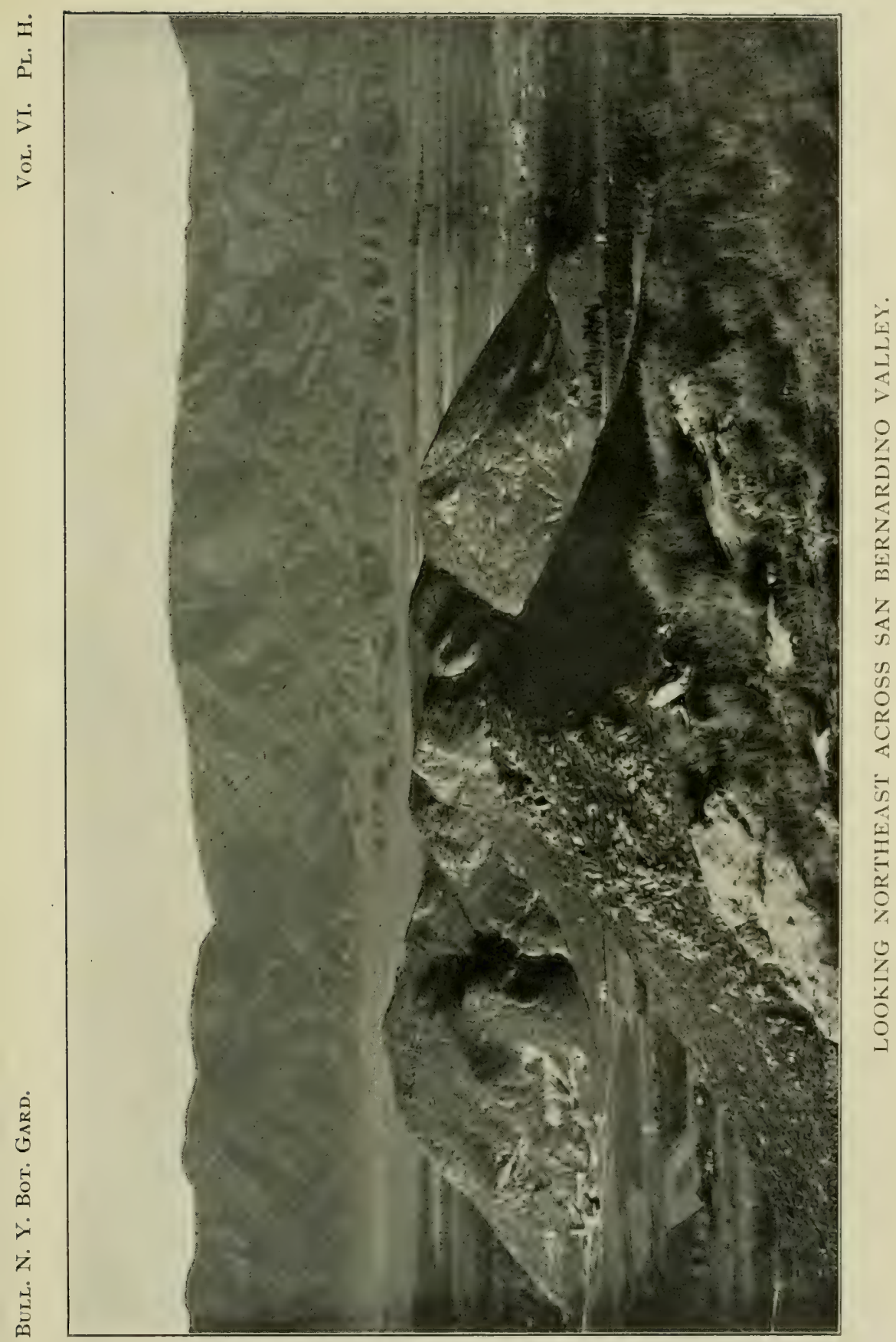





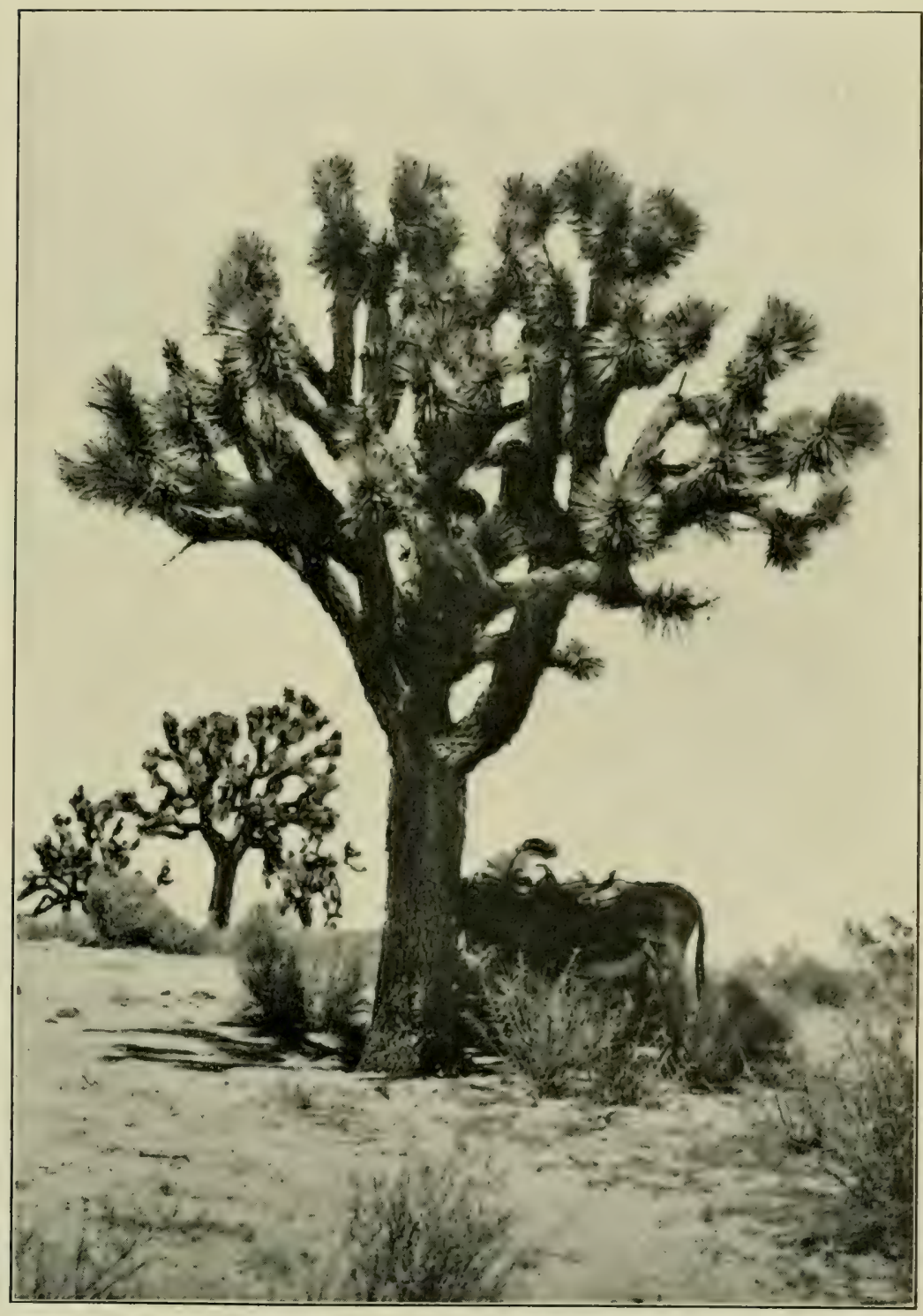

CLEISTOYUCCA ARBORESCENS. MOHAVE DESERT. 



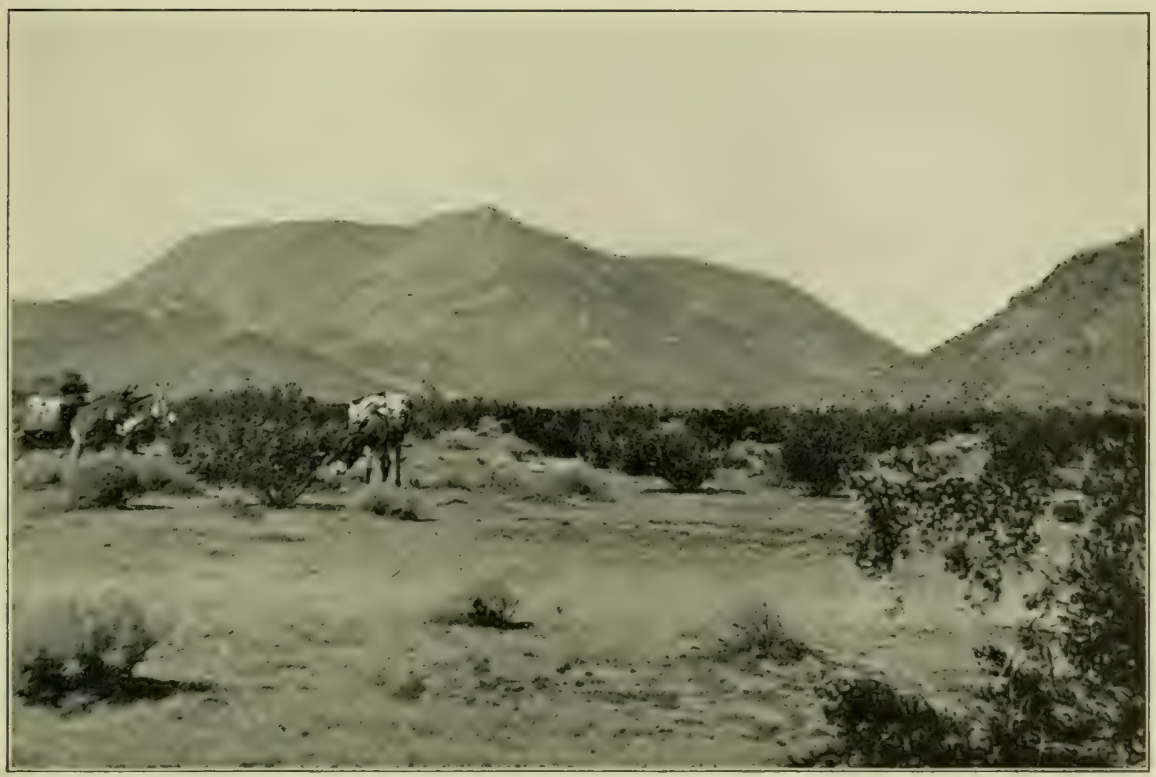

FIG. I.

COVILLEA 'TRIDENTATA. NEAR WILLOW SPRINGS.

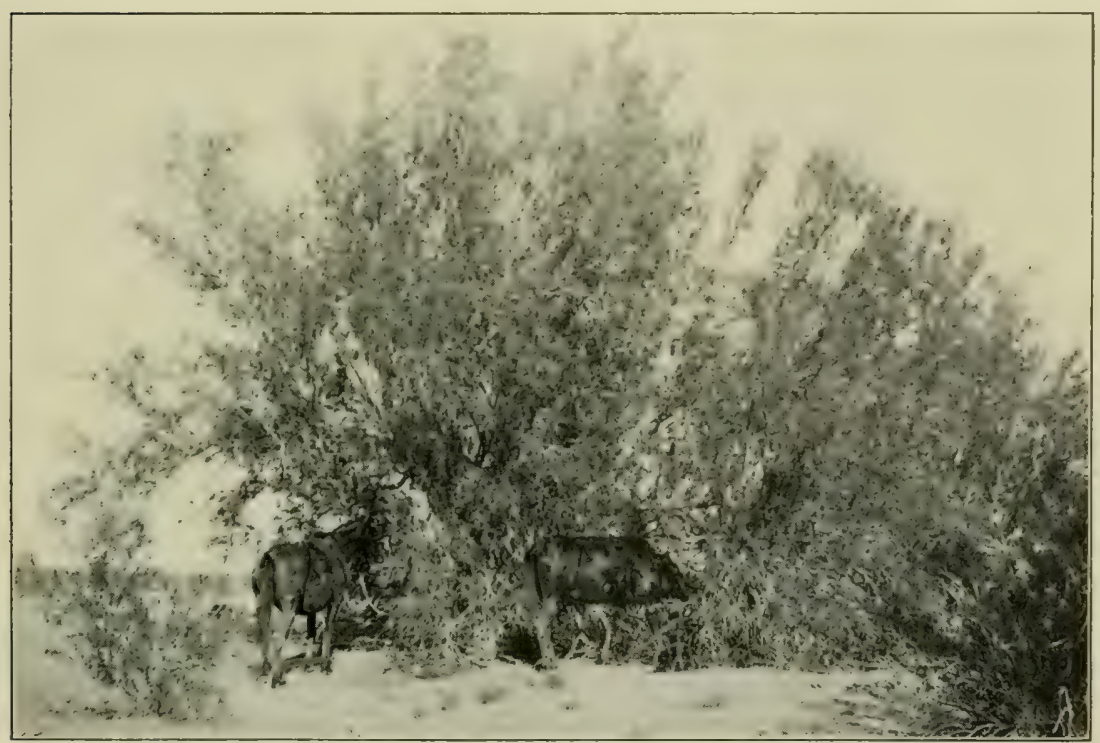

FIG. 2 .

OLNEYA TESOTA. SIGNAL MOUNTAIN. 



\section{$\left(3^{23}\right)$}

Plate G

Pinus Sabiniana, Oakgrove Canyon, Liebre Mountains, altitude 1400 meters. Upper Austral Zone.

\section{Plate H}

Looking northeast across San Bernardino Valley, with Slover Mountain in the foreground and the San Bernardino Mountains in the distance. The valley is Lower Austral; the chaparral-covered slopes of the distant mountains, Upper Austral; the forests on the summits, Transition.

\section{Plate I}

Cleistoyucca arborescens, Mohave Desert, between Mohave and Lancaster, altitude about 800 meters. Lower Austral Zone.

\section{Plate J}

Fig. I. Cooillea tridentata, near Willow Springs, Antelope Valley, altitude about 840 meters. Lower Austral Zone.

Fig. 2. Olneya Tesota, eastern base of Signal Mountain, Colorado Desert, altitude about sea level. Lower Austral Zone.

\section{ANNOTATED CATALOGUE OF THE SOUTHERN CALIFORNIA TREES AND SHRUBS}

\section{PINACEAE. Pine Family.}

Leaves usually fascicled, surrounded at base by a sheath; cones maturing the second year.

I. Pinus.

Leaves not fascicled, without basal sheath; cones maturing the first year.

Cones pendulous; leaves short-petioled.

Cones erect; leaves sessile.
2. Pseudotsuga.

3. Abies.

\section{PINUS, Pine.}

Sheaths deciduous; leaves with I fibro-vascular bundle.

Leaves in 5 's.

Leaves slender, 8-10 $\mathrm{cm}$. long; cones cylindrical, 20-40 cm. long; wing of seed $2 \mathrm{~cm}$. long. $\quad$ I. $P$. Lambertiana.

Leaves rigid, 3-6 cm. long; cones oval, $8-16 \mathrm{~cm}$. long; wing a narrow ring, I mm. broad. 2. $P$. Alexilis.

Leaves $\mathbf{I}-4$ in a cluster; cones globose; scales much thickened; seeds large.

Leaves usually in 4 's. $\quad 3$. P. quadrifolia.

Leaves solitary. $\quad 4$. P. monophylla.

Sheaths persistent; leaves with 2 fibro-vascular bundles.

Leaves in 5's, wing thickened.

Leaves in 2's or 3's; wing thin.

5. P. Torreyana.

Leaves in 3 's.

Cones deciduous; scales tipped with a prickle.

Cones $7-12 \mathrm{~cm}$. long.

6. P. ponderosa. 
Cones $12-25 \mathrm{~cm}$. long.

6a. P. ponderosa Jeffreyi.

Cones more persistent; scales tapering to stout incurved points.

Leaves grayish-green, drooping; cones chestnut brown, oval, 15-25 cm. long.

7. P. Sabiniana.

Leaves blue-green, erect; cones yellowish-brown, long-oval, Leaves in 2's.

$25-35 \mathrm{~cm}$. long. $\quad$ 8. P. Coulteri.

Cones deciduous, opening at maturity.

9. P. Murrayana.

Cones persistent for years, not opening at maturity.

Io. $P$. attenuata.

I. Pinus Lambertiana Dougl. Trans. Linn. Soc. 15: 500.1827.

Pinus Lambertiana minor Lemmon, Second Bienn. Rep. Calif. State Forest. 70, 83. I888.

Type locality: On the head waters of the Umpqua River.

Distribution: The Sugar pine is characteristic of the Sierran District. It occurs from central Oregon southward to San Pedro Martir Mountain, Lower California. Transition.

Specimens examined: Mount Pinos, Elmer 4196; Swartout Valley, San Gabriel Mountains, Abrams है McGregor 650; Mount San Antonio, Abrams 270I; Strawberry Valley, San Jacinto Mountains, Leiberg 3I4I; Mount San Gorgonio, Dutton, I897; mountains east of San Diego, Parry, I850.

2. Pinus flexilis James, Long's Exped. 2: 27. 1823.

Type locality: "Inhabits the arid plains subjacent to the Rocky Mountains, and extends up their sides to the region of perpetual frost."

Distribution: The limber pine occurs on the eastern slopes of the continental divide from Alberta to western Texas, and ranges westward over the mountains of Wyoming, Utah, Nevada, northern New Mexico, northern Arizona and southeastern California. In California it is found along the eastern slope of the Sierra Nevada south of Mono Pass, on the Inyo and Panamint Mountains, and on some of the higher peaks of southern California as noted below. It is characteristic of the Canadian Zone.

Specimens examined: Summit of Mount Pinos, Abrams E McGregor 243; North Baldy, San Gabriel Mountains, Abrams Eे McGregor 605; Dry Lake, Mount San Gorgonio, altitude 2800 meters, Abrams Eं McGregor 785; near the summit of Mount San Gorgonio, Abrams E McGregor 748; Leiberg 3279. 
Pinus monticola and Pinus albicaulis have been reported from southern California, but I have not seen any specimens, and their presence within our range is doubtful.

3. Pinus Quadrifolia Parry; Parl. in DC. Prod. 16, pt. 2: 402. 1868.

Pinus parryana Engelm. Am. Journ. Sci. II. 34: 332. I862. Not Gord. 1858.

Type locality: "On the mountains east of San Diego."

Distribution: Parry's pine occupies a belt on the mountains of northern Lower California corresponding to that of $P$. monophylla on the mountains bordering the Mohave Desert. It extends northward, sparingly, along the desert slope to the Santa Rosa Mountains of southern California. Upper Sonoran.

Specimens examined: Coyote Canyon, Santa Rosa Mountains, Leiberg 3164; Hall 2139; mountains east of San Diego, Parry, I850; near Walker's ranch, between Campo and Jacumba Hot Spring, Vasey, 1880.

4. Pinus monophylla Torr. \& Frem. in Frem. Second Rep. 319 , pl. 4. 1845 .

Pinus Fremontiana Endl. Syn. Conif. 183. I847, in part.

Type locality: "Extensively diffused over the mountains of northern California from long. $11 \mathrm{I}^{\circ}$ to $120^{\circ}$, and through a considerable range of latitude."

Distribution: The piñon is characteristic of the Great Basin district. It extends over the mountains of the Great Basin, ranging westward to the eastern slopes of the Sierra Nevada and southward along the desert slopes of the southern California mountains to the northern border of Lower California. In southern California the piñon forms a distinct belt along the northern slopes of the San Gabriel and the San Bernardino Mountains, ranging from 1000 to 1500 meters in altitude. South of the San Bernardino Mountains it becomes rare and finally is superseded by $P$. quadrifolia near the Mexican boundary. Upper Sonoran.

Specimens examined: Mount Pinos, Elmer 3983; near the Frazier Borax Mine, Mount Pinos, Abrams \& McGregor 269; Mutau Flat, head of Piru Creek, Abrams \& McGregor I86; Lone Pine Canyon, San Gabriel Mountains, Abrams \& McGregor 669; between Bear Valley and Cushenberry Spring, Abrams 2136; Morongo King 
Mine, San Bernardino Mountains, Parish 3456; eastern slope of Mount San Jacinto, 800 meters, Leiberg ${ }_{316}$.

5. Pinus Torreyana Parry, Bot. Mex. Bound. $210, p l .58,59$. I859.

Pinus lophosperma Lindl. Gard. Chron. 1860: 46. I860.

Type locality; "Bluffs near the mouth of Solidad Creek, Io miles north of San Diego, California."

Distribution: The Del Mar or Torrey pine has the most restricted range of any pine in North America. It extends along the coast in the vicinity of Soledad River, San Diego County, for about 8 miles and inland 2 or 3 miles. In addition to this one locality it has been found only on the east end of Santa Rosa Island. Upper Sonoran or Lower Sonoran.

Specimens examined: Santa Rosa Island, Blanche Trask, Oct. I900; Soledad, Pringle, April 26, 1882; Dudley, July 24, I899.

6. Pinus ponderosa Dougl.; Lawson, Man. Agr. 354. 1836.

Type locality: Washington, on the Spokane River, according to Piper.

Distribution: The western yellow pine is the most characteristic tree of the Western Arid Area of the Transition Zone, extending from British Columbia southward to western New Mexico and southern California. In southern California this pine is common throughout the Transition Zone of all the mountain ranges.

Specimens examined: Water Canyon, Tehachapi Mountains, Abrams छ McGregor 478; Tejon Pass, Coville छீ Funston 1223; Santa Ana Canyon, San Bernardino Mountains, altitude 1500 meters, Abrams छٌ McGregor, July 14, Igo8.

6a. Pinus ponderosa Jefrrexi (Murray) Vasey, Rep. Com. Agr. 1875: $179 . \quad 1876$.

Pinus Jeffreyi Murray, Rep. Bot. Exped. Oreg. 2, pl. r. 1853. Pinus deflexa Torr. Bot. Mex. Bound. 209. 1859.

Type locality: "Shasta Valley, N. California."

Distribution: Cascade Mountains of southern Oregon southward through the Sierra Nevada and southern California to San Pedro Martir. The separation of this pine from typical Pinus ponderosa 
is often difficult in southern California. Some trees with plated bark have small cones, and others have cones fully as large as any of the variety. Both extremes also occur on trees with the darker furrowed bark. In almost any locality, but especially in the vicinity of Green Valley, San Bernardino Mountains, it is possible to gather a series of cones ranging in size from the typical to that of the variety.

Specimens examined: Mount Pinos, Abrams Eं McGregor 24I; Mount San Gorgonio, Dutton, r897; mountains east of San Diego, Parry, I850.

7. Pinus Sabiniana Dougl. Trans. Linn. Soc. 16: 749. 1833.

Type locality: Indefinite, but probably from the mountains near San Juan Mission, Monterey County. Douglas forwarded his paper in which this species was described from this place.

Distribution: The digger pine is characteristic of the Intramontane District, occupying a distinct belt below the Sierran District on the western slope of the Sierra Nevada, and on the inner Coast Ranges. A few trees penetrate through Tejon Pass and extend southward along the western margin of Antelope Valley to Elizabeth Lake, Liebre Mountains. Upper Sonoran.

Specimens examined: Oakgrove Canyon, Liebre Mountains, Abrams \& McGregor 399.

8. Pinus Coulteri Lamb. in Don, Trans. Linn. Soc. 17: 440. 1837 .

Pinus macrocarpa Lindl. Bot. Reg. Misc. 6r. 1840.

Pinus Sabiniana Coulteri Don; Loud. Arb. et Fruti. 4: 2250. 1838.

Type locality: "On the mountains of Santa Lucia near the Mission of San Antonio, in latitude $36^{\circ}$, within sight of the sea and at an elevation of from 3000 to 4000 feet above the sea."

Distribution: Coulter's pine occurs in the Coast Ranges of California from the vicinity of Mount Diablo south to the Cuiamaca Mountains. In southern California it is scattered, usually sparingly, through the coniferous forests of the San Gabriel, the San Bernardino, the San Jacinto and the Cuiamaca Mountains. In the latter range it forms considerable forest around Julian. Transition. 
Specimens examined: La Cumbre Peak, Santa Ynez Mountains, Abrams 4315; Deep Creek, San Bernardino Mountains, Abrams 2067; The Pines, Santa Ana Canyon, San Bernardino Mountains, Abrams Eक McGregor 8II; Santa Ana Mountains, near Elsinore, Dutton, I 897; near Julian, Cuiamaca Mountains, Vasey, June, I880.

9. Pinus Murrayana Balfour, Rep. Bot. Exped. Oreg. 2, pl. 3, f. 2. $\mathrm{I} 853$.

Pinus contorta Murrayana Engelm. Bot. Calif. 2: I26. I880.

Type locality: "On the Siskiyou Mountains."

Distribution: The lodge-pole pine extends from southern Alaska south and east to southern Colorado and Utah, and on the Pacific Coast along the higher altitudes of the mountain ranges to Mt. San Pedro Martir, Lower California. In southern California it is confined to the Canadian Zone, seldom being found below 2400 meters.

Specimens examined: North Baldy, San Gabriel Mountains, Abrams Eं McGregor 624; Mount San Antonio, Abrams 1946; Bear Valley, San Bernardino Mountains, Abrams 2080; Mount San Gorgonio, Leiberg 3280; Abrams E McGregor $78 \mathrm{I}$.

Io. Pinus attenuata Lemmon, Gard. \& Forest 5: 65. 1892. Pinus californica Hartw. Journ. Hort. Soc. 2: 189. I847. Not Loisel. I8I2.

Pinus tuberculata Gord. Journ. Hort. Soc. 4: 218. I849. Not Don. 1837 .

Type locality: "To the south of Monterey, in lat. $36^{\circ}$, near the level of the sea, and growing almost to the beach." The locality given here is that for $P$. tuberculata, since $P$. attenuata was based upon that species.

Distribution: The knob-cone pine extends from Mackenzie River, Oregon to the San Bernardino Mountains. In southern California it is limited to a narrow belt along the southern slope of the San Bernardino Mountains in the vicinity of the City Creek Canyon. Upper Sonoran.

Specimens examined: San Bernardino Mountains, on the City Creek road, altitude 875 meters, Abrams 2802. 
2. PSEUdOTSUGA. Douglas fir.

I. Pseudotsuga macrocarpa (Torr.) Mayr. Wald. Nordam. 278. I 890.

Abies Douglasii macrocarpa Torr. Ives Rep. 28. I86r.

Abies macrocarpa Vasey, Gard. Monthly 1876: 22. 1876.

Pseudotsuga Douglasii macrocarpa Engelm. Bot. Calif. 2: I20.

I 880 .

Type locality: "Mountains near San Felipe," San Diego County.

Distribution: The big-cone spruce is the most characteristic tree of southern California. It occupies the upper altitudes of the Upper Sonoran on the coastal slope and extends into the lower parts of the Transition Zone. It occurs in the Santa Ynez Mountains, and in the vicinity of Fort Tejon extends southward to San Pedro Martir Mountain.

Specimens examined: La Cumbre Peak, Santa Ynez Mountains, Abrams 43I4; Fort Tejon, Abrams Eै McGregor 30I; Topatopa Mountains, Abrams \& McGregor 8I; Mount Wilson, San Gabriel Mountains, Abrams, July, 1906; Cleghorn Canyon, San Bernardino Mountains, Abrams E McGregor 706; Mount Santiago, Santa Ana Mountains, Helen D. Geis, 1903.

\section{ABIES. FIR.}

I. Abies concolor Lindl. \& Gord. Journ. Hort. Soc. 5: 2 Io. 1850.

Picea concolor Gord. Pinetum I55. $185^{8 .}$

Type locality: "On the mountains of New Mexico."

Distribution: Mountains of southern Oregon south to Mount San Pedro Martir, and extending eastward over the mountains of Nevada, Utah, western Colorado, and northern Arizona and New Mexico. In southern California the white fir is one of the common components of the coniferous forests especially in the upper half of the Transition Zone.

Specimens examined: Mount Pinos, Elmer 4198; Abrams E' McGregor 254; Mount San Antonio, San Gabriel Mountains, Abrams, July, I90r; Strawberry Valley, San Jacinto Mountains, Leiberg 3 I39. 


\section{CUPRESSACEAE. Cypress Family.}

Monoecious; cone-scales woody.

Leaves in whorls of 4 ; cones and scales oblong.

Leaves opposite; cones globose; scales peltate.

r. Heyderia.

2. Cupressus.

Dioecious; leaves opposite; cones berry-like, their scales becoming fleshy.

3. Juniperus.

I. HEYDERIA. INCENSE CEDAR.

I. Heyderia decurrens (Torr.) K. Koch, Dendrol. 2: 177. I873.

Libocedrus decurrens Torr. Pl. Frem. pl. 3. 1854.

Type locality: "Upper waters of the Sacramento, particularly from lat. $38^{\circ} 4 \mathrm{O}^{\prime}$ to about $4 \mathrm{I}^{\circ} \mathrm{N}$. lat."

Distribution: The post or incense cedar extends from the Santiam River in the southern Cascade Mountains southward through the Sierran District, of which it is one of the most characteristic trees. The southern limit, as that of so many of the trees peculiar to the Sierran District, is Mount San Pedro Martir, Lower California. Transition.

Specimens examined: Rock Creek Canyon, San Gabriel Mountains, Abrams छ̋ McGregor 574; Huston's Flat, San Bernardino Mountains, Shaw, Aug. 1900; Strawberry Valley, San Jacinto Mountains, Leiberg 3149; Cuiamaca Mountains, near Talley's ranch, Palmer 3; Laguna, Mearns 3653.

\section{CUPRESSUS. Cypress.}

I. Cupressus guadalupensis S. Wats. Proc. Am. Acad. 14: 300. I879.

Cupressus macrocarpa guadalupensis Masters, Journ. Linn. Soc. 31: 343 . 1896.

Type locality: "On Guadalupe Island, off the coast of Lower California."

Distribution: A small grove of cypress near the Jamul Valley, San Diego County, seems to belong to this insular species.

Specimens examined: Cypress canyon, between Oneonta and Dulgura, Forbes, Dec. 3, 1907. 


\section{JUNIPERUS. JUNIPER.}

Seeds I or 2 ; cotyledons $4-6$.

Leaves rounded at the apex, conspicuously glandular on the back.

Leaves acute or acuminate, glandless.

I. J. californica.

2. J. utahensis.

Seeds 2 or 3 ; cotyledons 2 ; leaves conspicuously glandular on the back.

3. J.occidentalis.

I. Juniperus californica Carr. Rev. Hort. IV. 3: $352, f .21$. 1854 .

Juniperus tetragona osteosperma Torr. Pacif. R. Rep. 4: I4I. I857. Sabina californica Antoine, Cupress. Gatt. 52, pl. 7I, 72. 1857.

Type locality: "En Californie."

Distribution: The California juniper is characteristic of the desert slopes of the mountains extending from the southern Sierra Nevada to Lower California. It also occurs in the more arid parts of the Great Valley, and on dry washes on the coastal slope in southern California. Upper and Lower Sonoran.

Specimens examined: Ten Sycamore Flat, Sespe Creek, Abrams छ McGregor 168; Fort Tejon, Abrams E McGregor 302; Palmdale, Elmer 3633; Big Tejunga Wash, San Fernando Valley, Abrams 1374; Rock Creek, San Gabriel Mountains, Abrams छ' McGregor 53I; Lone Pine Canyon, San Gabriel Mountains, Abrams है McGregor 618; Cajon Pass, Coville छ Funston 125; Morongo Canyon, Parish 2085; near Mentone, Abrams E McGregor 824; San Felipe Canyon, Palmer 17; San Jacinto Moutains, Leiberg 3159; Jacumba Hot Spring, Abrams 3648, 3649.

2. Juniperus utahensis (Engelm.) Lemmon, Rep. Calif. Stàte Board Forest. 3: 183, pl. 28, f. 2. 1890.

Juniperus californica utahensis Engelm. Trans. St. Louis Acad. 3: 588 . I 877 .

Juniperus occidentalis utahensis Veitch, Man. Conif. 289. I88I.

Type locality: "All over the southern parts of Utah and into Arizona and Nevada."

Distribution: Western Colorado and Utah to northern Arizona and the eastern limits of the Mohave Desert, where it occurs within our range on the Providence Mountains. (See introduction.) Upper Sonoran.

Specimens examined: Providence Mountains, Brandegee, May 26, 1902 . 
3. Juniperus occidentalis Hook. Fl. Bor. Am. 2: i66. i 838.

Type locality: "Common on the higher parts of the Columbia."

Distribution: This juniper extends from western Idaho and eastern Washington southward along the Cascade Mountains and the Sierra Nevada to the San Jacinto Mountains. In southern California it is found in the vicinity of Bear Valley, and toward the summits of Mount San Antonio and Mount San Jacinto, occupying an arid belt intermediate between the Transition and the Canadian Zones.

Specimens examined: Bear Valley, San Bernardino Mountains, Leiberg 3316; Abrams, Aug. 3, rgor.

\section{GNETACEAE. Joint-Fir Family.}

\section{EPHEDRA. MExican teA.}

Scales and bracts in 2's.

Branches bright green, erect and broom-like. I. E. viridis.

Branches pale glaucous green, divergent. 2 2. E. nevadensis.

Scales and bracts in 3 's.

3. E. californica.

I. Ephedra viridis Coville, Contr. Nat. Herb. 4: 220. 1893.

Type locality: "Near Crystal Spring, Cosco Mountains, Inyo County, California."

Distribution: Western slopes of the Mohave Desert eastward to southern Nevada. This species is characteristic of the piñon belt on the mountain slopes of the Mohave Desert. Upper Sonoran.

Specimens examined: Frazier Borax Mine, Mount Pinos, Abrams E McGregor 2I6, 2I7; Ten Sycamore Flat, Sespe Creek, Abrams छ McGregor 174; near Bear Valley, Leiberg 3315; Cushenberry Spring, Parish 4980; Rose Mine, San Bernardino Mountains, Parish 2975.

2. Ephedra nevadensis S. Wats. Proc. Am. Acad. 14: $298 . \quad$ i879. Type locality: "Pah Ute Mountains, altitude 5000 feet; Carson City, altitude 5000 feet."

Distribution: Nevada and Utah southward through the desert regions to Lower California. In southern California this species is characteristic of the juniper and the yucca belts of the deserts. Upper and Lower Sonoran.

Specimens examined: Mohave Desert, near Varren Station, Abrams \& McGregor 499; near Acton, Elmer 3599; Jacumba Hot Spring, Abrams 3676; Mountain Spring, Mearns 3079. 
3. Ephedra californica S. Wats. Proc. Am. Acad. 14: 300. I879.

Type locality: "Promontory near San Diego, and Jamul Valley."

Distribution: The Mohave Desert, southward to Lower California, extending westward to the coast in the vicinity of San Diego and southward. Lower Sonoran.

Specimens examined: Between Victor and Stoddard Wells, Coville छ' Funsten 159; Whitewater, S. B. छ W. F. Parish 653; eastern slope of San Gorgonio Pass, Leiberg 3234; Coyote Canyon, Santa Rosa Mountains, Hall 2863; Jacumba Hot Spring, Mearns 3332; Campo, Abrams 3600; North Coronado, Knapp, I895; Tia Juana, Abrams 3489 .

PHOENICACEAE. Palm Family.

I. NEOWASHiNGTONIA. California fan-palm.

I. Neowashingtonia filamentosa Sudworth, U. S. Dept. Agr. Div. Forest. Bull. no I4: 105. I 897.

Pritchardia filamentosa Wendl. Bot. Zeit. 34: 807. 1876.

Pritchardia flifera Linden, Ill. Hort. 24. 1877.

Washingtonia filifera Wendl. Bot. Zeit. 37: 68. I 879.

Washingtonia filamentosa Kuntze, Rev. Gen. Pl. 2: 737. I891.

Type locality: Described from young plants cultivated in Europe. The source of the seeds is not definitely known.

Distribution: The California fan-palm occurs in a few scattered groves along the base of the desert ranges a few miles north of Indio, and again at Palm Springs on the eastern base of Mount San Jacinto. An interesting account, and an exhaustive bibliography of the genus, was given by Parish in the Botanical Gazette, Dec., 1907.

Specimens examined: Palm Springs, Dudley, Dec. I902.

\section{LILIACEAE. Lily Family.}

Flowers polygamo-dioecious; perianth-segments I-nerved; filaments filiform; fruit thin and membranous, bursting irregularly. I. Nolina.

Flowers perfect; perianth-segments many-nerved; filaments clavate; fruit a thick-walled capsule, or baccate, septicidal or loculicidal.

Style filiform; stigma capitate, long-papillate.

2. Hesperoyucca.

Style stout or wanting, 6-notched, openly perforate. 
Perianth-segments thick; nectar glands small; style wanting.

Perianth-segments thin; nectar glands large; style evident.

3. Cleistoyucca.

4. Yucca.

\section{NOLINA.}

I. Nolina Parryi S. Wats. Proc. Am. Acad. 14: 247. I879. Type locality: "California (western border of the San Bernardino Desert); Parry, I876."

Distribution: Desert slopes of the San Bernardino and the San Jacinto Mountains on the western border of the Colorado Desert. Lower Sonoran.

Specimens examined: Rattlesnake Canyon, San Bernardino Mountains, Parish 3I45; Tahquitz Valley, San Jacinto Mountains, altitude 2000 meters, Hall 2432; Southeastern base of Mount San Jacinto, altitude 1500 meters, Hall I819; San Felipe, Brandegee, April 30, I894.

\section{HESPEROYUCCA. SPanish bayonet.}

I. Hesperoyucca Whippleı (Torr.) Baker, Kew Bull. 1892: 8. 1892.

Yucca Whipplei Torr. Bot. Mex. Bound. 222. I859.

Yucca graminifolia Wood, Proc. Acad. Philad. 1868: I67. I 868. Yucca Whipplei graminifolia Baker, Journ. Linn. Soc. 18: 230. I880.

Type locality: "Near San Pasqual, southern California."

Distribution: Monterey County and the southern Sierra Nevada southward to the vicinity of Alamo, Lower California. In southern California the Spanish bayonet is common throughout the chaparral covered areas of the coast slope; it also occurs in the piñon belt of the desert slopes. A purple flowered form was collected by the writer (3547) in the foothills of San Diego County. In the vicinity of Fort Tejon (Abrams \& McGregor 270) a more compact form, with flowers scarcely half the normal size, grows associated with typical plants.

Specimens examined: Soldiers Camp, near Fort Tejon, Abrams छ McGregor 270, 27I; Sulphur Mountain Spring, Abrams छ० McGregor 4I; Sepulveda Canyon, Santa Monica Mountains, Abrams 2564; Cajon Pass, Bigelow, 1853; San Pasqual, Schott; near Dulzura, Abrams 3547. 
3. Cleistoyucca. Joshua tree.

I. Cleistoyucca arborescens (Torr.) Trelease, Rep. Mo. Bot. Gard. 13: 4I. 1902 .

Yucca draconis arborescens Torr. Pacif. R. Rep. 4: 147.1857. Yucca brevifolia Engelm. King Exped. 5: 496. 1871. Not Schott. 1859.

Yucca arborescens Trelease, Rep. Mo. Bot. Gard. 3: I63. 1892 .

Type locality: "Sandy and gravelly plains west of the Colorado, California."

Distribution: Mohave Desert of southern California east and north to southern Nevada, northeastern Arizona, and southwestern Utah. It forms orchard-like groves between the juniper and Covillea belts. Lower Sonoran.

Specimens examined: Desert slopes of the Tehachapi Mountains, near Willow Springs, Abrams \& McGregor 430.

\section{YUCCA. YUCCA.}

I. Yucca mohavensis Sargent, Gard. \& For. 9: 104. I896.

Type locality: "Most abundant and grows to its largest size on the Mohave Desert."

Distribution: Northwestern Arizona and southwestern Nevada westward through the Mohave Desert and southward along the western border of the Colorado Desert to northern Lower California, where it extends westward into the coastal region in the vicinity of San Diego. This species is said to have been collected by Parry near Monterey, but we strongly suspect that this is an error through confusion of labels. Parry's plants in all probability came from San Diego, for so far as we are aware the plant has not been found in the coastal region north of this locality.

Specimens examined: San Dieguito (Bernardo), Abrams 3409; San Diego, Jones 3163; San Timotea Canyon, Hall 575I; western base of Mount Santa Rosa, Hall 1905.

\section{SAliCACEAE. Willow Family.}

Stamens numerous, bracts fimbriate or lacerate.

Stamens 1-5; bracts entire or denticulate.
I. Populus.

2. Salix. 
I. POPUlUS. Poplar or Cottonwood.

Petioles terete; ovary tomentose.

I. P. trichocarpa.

Petioles flattened; ovary glabrous.

Leaves coarsely serrate-dentate; capsules globose; stigma-lobes dilated. 2. P. Fremontii.

Leaves finely crenate-serrate; capsules oblong-conic; stigma-lobes linear.

3. P. tremuloides.

I. Populus trichocarpa Torr. \& Gray; Hook. Ic. Pl. 9: pl.878. 1852 .

Type locality: "Santa Clara River, near Beneventano [Ventura], California."

Distribution: British Columbia and western Montana, southward throughout California. The mountain forms often develop narrow leaves that approach $P$. angustifolia, but there seem to be no stable characters that warrant their separation as a distinct variety or species. In southern California this species occurs in the Upper Sonoran on the coastal slope, and in the Transition and the lower altitudes of the Canadian Zones. In the Lower Sonoran of the interior valleys, at San Diego, and on the deserts, it is replaced by $P$. Fremontii.

Specimens examined: Sulphur Mountain Spring, near Santa Paula, Abrams E McGregor 58; Monrovia Canyon, San Gabriel Mountains, Dudley, Nov. 20, 1907; Bear Valley, San Bernardino Mountains, Abrams \& McGregor 738 .

2. Populus Fremontil S. Wats. Proc. Am. Acad. 10: 350. 1875. Type locality: "On Deer Creek at 'Lassen's' in the upper Sacramento Valley."

Distribution: Sacramento Valley south to northern Lower California, and eastward to southern Colorado and western Texas. In southern California this species occurs along most of the streams of the interior valleys, approaching the coast in San Diego County; it is also abundant in the canyons on the desert slopes of all the mountains. A form with pubescent twigs, foliage, and peduncles, which occurs on the delta of the Colorado River, may prove worthy of recognition when more complete material is at hand. My own specimens from Elsinore Lake are fully as pubescent as the delta plants, but specimens from Cajon Pass (Abrams E McGregor 695) are only sparsely so, thus approaching the typical form which is glabrous. 
Specimens examined: Elizabeth Lake, Liebre Mountains, $A b$ rams E McGregor 412; Rock Creek, San Gabriel Mountains, Abrams E McGregor 556; near Claremont, Baker 5347; Cajon Pass, Abrams \& McGregor 695; San Bernardino, Parish, March, I902; San Dieguito River, near San Dieguito (Bernardo), Abrams 3370; Calexico, G. D. Abrams, Feb., I9ro.

3. Populus tremuloides Michx. Fl. Bor. Am. 2: 243. 1803.

Type locality: "Hab. in Canada et Noveboraco."

Distribution: The quaking aspen is distributed through the Canadian Zone of California, and extends from San Pedro Martir northward to Alaska, thence across the northern part of the continent, ranging southward along the mountains to New Mexico and Pennsylvania. Only one locality has been discovered in southern California, viz., Grinnell (Univ. Calif. Pub. Zoology 5: 34 . 1908) reports several groves "on the west side of the upper Fish Creek Canyon, north of San Gorgonio Peak, at altitudes of 7000 to 7600 feet."

\section{SALIX. WILLOW.}

Stamens 3 or more; bark furrowed; trees.

Leaves green on both surfaces; stipules glandular; ovary often pubescent.

Leaves pale beneath; capsule glabrous.

I. S. vallicola.

Petioles with glands near the base of the blade; stipules conspicuous, glandular.

2. S. lasiandra.

Petioles and stipules not glandular, the latter often wanting.

Stamens 2; bark not furrowed; trees or shrubs.

3. S. laevigata.

Scales of the ament black or black-tipped.

Ovary and capsule glabrous.

Leaves entire or remotely and obscurely serrate, becoming rustyglaucous beneath; scales pubescent or short-villous.

4. S. lasiolepis.

Leaves finely serrate, becoming smooth and pale beneath; scales long-villous.

5. S. Watsoni.

Ovary and capsule pubescent.

Aments appearing before the leaves; styles none.

Aments appearing with the leaves; styles evident.

6. S. Scouleriana.

7. S. glaucops.

Scales of the ament pale.

Ovary glabrous; leaves sparsely appressed-pubescent.

8. S. exigua.

Ovary pubescent at least sparsely so when young; leaves more or less densely silky.

9. S. argophylla. 
I. Salix valitcola (Dudley) Britton, N. Am. Trees I84. 1908. Salix nigra vallicola Dudley in Abrams, Fl. Los Angeles 100. I904. Type locality: "Along the Santa Ana River near Orange," California.

Distribution: Streambanks in the Sacramento and San Joaquin valleys, southward into southern California. This variety differs from the true Salix nigra in its glandular stipules, and obovate or rounded instead of ovate bracts of the staminate aments. Specimens from the Colorado Desert (Abrams 3195) have the bracts of the staminate aments glandular-toothed. There are other evidences that this desert plant is distinct from the coast species, but more material is needed to satisfactorily determine its relationship. Upper and Lower Sonoran.

Specimens examined: Gorman's Station, Antelope Valley, Abrams \& McGregor 314; Santa Ana River, near Orange, Abrams 3256; near Santa Ana, Helen D. Geis; Elsinore, Baker 4r46; San Dieguito River, Abrams 337I; San Diego River, San Diego, Abrams 3410; Tia Juana, Abrams 3484; Blue Lake, Imperial County, Abrams 3195.

2. Salix lasiandra Benth. Pl. Hartw. 335. 1857.

Type locality: "Ad flumen Sacramento."

Distribution: Southwestern British Columbia and western Washington and Oregon, southward to southern California. Upper Sonoran and Transition.

Specimens examined: Los Angeles River, near Tropico, Abrams I449; Pasadena, Grant II6o; vicinity of San Bernardino, Parish 4635, 4677; Bear Valley, San Bernardino Mountains, Abrams छ McGregor 739 .

3. Salix laevigata Bebb. Am. Nat. 8: 202. I874.

Type locality: "California, at Santa Cruz, also 'Ukiah' and Alameda Co."

Distribution: Siskiyou County south to the northern part of Lower California. In southern California this species is frequent along the principal streams. Upper Sonoran and Transition.

Specimens examined: Sulphur Mountain Spring, near Santa Paula, Abrams \&ै McGregor 60; Topatopa Mountains, Abrams छ McGregor I2I; Los Angeles River, near Rivera, Abrams 3253; Ballona Creek, near Mesmer, Abrams 1467; near Chatsworth, 
Abrams 1362; Santa Ana, Helen D. Geis 554; Cosey Dell, Cajon Pass, Abrams \& McGregor, 693; West Fork of Mohave River, Abrams \& McGregor 722; Jamul Valley, Susan G. Stokes, July, I895; near El Nido, Abrams 354I; Campo, Abrams 3615.

4. Salix lasiolepis Benth. Pl. Hartw. 335. 1857.

Type locality: "Ad ripas fluviorum Salinas et Carmel prope Monterey."

Distribution: Klamath River, southward to the northern part of Lower California, also in southern Arizona. In southern California this is the most common willow in the valleys and foothills. A form occurs in the upper parts of the Transition Zone strikingly different in habit. It is a bush forming low round clumps. The leaves are much smaller and paler.

Specimens examined: Santa Barbara, Elmer 39II; Santa Ynez Mountains, Elmer 3873; Topatopa Mountains, altitude 1860 meters, Abrams \&3 McGregor 105; Rock Creek, San Gabriel Mountains, Abrams छु McGregor 54I; Inglewood, Abrams 3103; vicinity of San Bernardino, Parish, May, I899; Fish Creek, San Bernardino Mountains, Grinnell 35.

5. Salix Watsoni (Bebb.) Rydb. Bull. Torr. Bot. Club 33: i37. I 906.

Salix cordata Watsoni Bebb. Bot. Calif. 2: 86. I 880.

Type locality: "Near Carson City (Watson), and in Sierra County, Lemmon."

Distribution: Utah westward to the eastern slopes of the Sierra Nevada and southward to the San Jacinto Mountains.

Specimens examined: Tahquitz Creek, San Jacinto Mountains, Hall 2447.

6. Salix Scouleriana Barratt; Hook. Fl. Bor. Am. 2: I45. 1838 . Salix flavescens Nutt. N. Am. Sylva 1: 65. 1842. Salix Nuttallii Sarg. Gard. \& Forest 8: 463.1895.

Type locality: "North West America, on the Columbia."

Distribution: Southern Assiniboia southward through the Rocky Mountains to northern New Mexico and Arizona, and along the Cascada Mountains and the Sierra Nevada to the San Bernardino Mountains. Transition.

Specimens examined: Faunskin Park, San Bernardino Moun- 


\section{$(340)$}

tains, Parish 4994; Snow Canyon, San Bernardino Mountains, Parish 5047; Deep Creek, San Bernardino Mountains, Abrams छ McGregor 729; Bluff Lake, Grinnell Ioo.

7. Salix glaucops Anderss. in DC. Prod. 16, pt. 2: 28I. 1858. Salix glauca villosa Anderss. Sal. Bor. Am. 22. 1858.

Salix glaucops villosa Anderss. in DC. Prod. 16, pt. 2: $28 \mathbf{r}$. I 858 .

Type locality: "In omni America septentrionali usque ad $\mathrm{fl}$. Saskatchawan crescere dicitur."

Distribution: British Columbia eastward to the Rocky Mountains and southward to New Mexico and southern California. Canadian Zone.

Specimens examined: Dollar Lake Canyon, altitude 2790 meters, Hall 7667; Abrams \& McGregor 767 .

8. Salix exigua Nutt. N. Am. Sylva 1: $75 . \quad$ I842.

Salix longifolia exigua Bebb. Bot. Calif. 2: 85. 1880.

Type locality: "On the immediate border of the Oregon below its confluence with the Wahlamet."

Distribution: The Columbia Basin, eastward through the Great Basin region and southward to New Mexico. In California I have seen specimens from only the Imperial Valley, where it is often abundant along the main canals and channels leading from the Colorado River. Upper and Lower Sonoran.

Specimens examined: Near Calexico, G.D. Abrams, July, 1902.

9. Salix argophylla Nutt. N. Am. Sylva 1: 71, pl. 20. 1842. Salix longifolia argophylla Anderss. in DC. Prod. 16, pt. 2: 214. I868.

Salix Hindsiana Benth. (?) Pl. Hartw. 335. 1857.

Salix Parishiana Rowlee, Bull. Torr. Bot. Club 27: 249. 1900. Salix macrostachya leucodermis Rowlee, Bull. Torr. Bot. Club 27: 250. 1900.

Type locality: "On the Boise River, toward its junction with the Shoshonee," Idaho.

Distribution: Washington south through Oregon and California to northern Lower California, and extending eastward to the Rocky Mountains. Upper and Lower Sonoran.

Specimens examined: Oakgrove Canyon, Liebre Mountains, 
Abrams है McGregor 406; Jacumba Hot Spring, Abrams 3679; Ten Sycamore Flat, Sespe Creek, Abrams \& McGregor I69; between Oakgrove Canyon \& Elizabeth Lake, Abrams \& McGregor 406; Inglewood, Abrams 1493; Cienega, Abrams, March, I899; vicinity of San Bernardino, Parish 4486; Waterman Canyon, Shaw Eं Illingsworth 4; Cosey Dell, Cajon Pass, Abrams E̊McGregor 694; Santa Ana River, Helen D. Geis 553; Tia Juana River, Herre, Aug. 1902, Abrams 3485; San Diego River, San Diego, Abrams 3419 .

\section{MYRICACEAE。 BAYBerRy FAMILY.}

\section{MYRICA. WAX MYRTLE.}

I. Myrica californica Cham. \& Sch. Linnaea 6:535. I831.

Type locality: "Legimus ad portum sancti Francisci Californiae."

Distribution: Moist, usually wooded slopes near the coast, from Puget Sound to the vicinity of Santa Monica. This species is most abundant in the Pacific Humid Area of the Transition Zone.

Specimens examined: Rustic Canyon, near Santa Monica, Hasse, May and July, I890; Mc Clatchie, Aug. 30, I896.

\section{JUGLANDACEAE. WALNUT Family.}

I. JUGLANS. Walnut.

I. Juglans californica S. Wats. Proc. Am. Acad. 10: 349. 1875, excluding synonymy.

Type locality: "Vicinity of San Francisco growing 40-60 feet high and $2-4$ feet in diameter, and ranging southward to Santa Barbara, Southern Arizona and Sonora."

Distribution: Ojai Valley, Ventura County, southward to the Santa Ana Mountains. It is most abundant on north slopes of the coastal mountains (Sulphur Mountain, Santa Monica Mountains, and Puente Hills) but extends eastward along the San Gabriel and the San Bernardino Mountains to the vicinity of San Bernardino. Upper Sonoran.

Specimens examined: Sulphur Mountain, Abrams छ० McGregor 9; Cahuenga Pass, Abrams 1243; Glendora, Baker 5294; Lone Pine Canyon, San Gabriel Mountains, Abrams छ० McGregor $60 I$. 


\section{BETUlaCEAE. Birch FAMily.}

\section{ALNUS. Alder.}

i. Alnus Rhombifolia Nutt. N. Am. Sylva 1: 33.1842. Type locality: "In the vicinity of Monterey, in Upper California."

Distribution: Idaho and eastern Washington south through the Sierra Nevada and the Coast Ranges to San Diego. In southern California the alder is most frequent along streams in the mountains from $400-1000$ meters. On the coastal slope it sometimes extends along the streams well into the valleys, especially in the vicinity of Pasadena. On the desert slopes it extends down the principal streams to the juniper belt. Transition and Upper Sonoran.

Specimens examined: Sulphur Mountain Spring, near Santa Paula, Abrams \& McGregor 59; Red Reef Canyon, Topatopa Mountains, Abrams \& McGregor 126; Rock Creek, desert slope of the San Gabriel Mountains, Abrams छ McGregor 527; Arroyo Seco, near Pasadena, Grant 36.

\section{FAGACEAE. BeEch Family.}

Involucre I-flowered; fruit an acorn.

Staminate aments densely flowered, erect; cup of acorn conspicuously echinate. I. Pasania.

Staminate aments loosely flowered, drooping; cup of acorn scaly (in ours), not echinate.

2. Quercus.

Involucre $1-3$-flowered, becoming a spiny bur in fruit.

3. Castanopsis.

I. PASANIA. TAN-BARK OAK.

I. Pasania densiflora (Hook. \& Arn.) Oerst. in Kloeb. Vidensk. Meddel. 84. 1866.

Quercus densiflora Hook. \& Arn. Bot. Beech. 391. I84I.

Type locality: "California." First collected by Douglas.

Distribution: The tan-bark oak extends from the Umqua Valley of southern Oregon southward through the Coast Ranges to Santa Barbara County, and on the western slopes of the Sierra Nevada as far south as Mariposa County. Transition.

Specimens examined: La Cumbre Peak, Santa Ynez Mountains, Abrams 4316. 


\section{QUERCUS. OAK.}

Styles slender, elongated; nut tomentose within; cup-scales thin; leaves or their lobes bristle-tipped; wood reddish. (Black oaks.)

Acorns developing the second year.

Leaves deciduous, large, deeply lobed. $\quad$ I. Q. Kelloggii.

Leaves evergreen, small, bright green and shiny beneath.

2. Q. Wislizeni.

Acorns developing the first year; leaves evergreen, pale beneath.

3. Q. agrifolia.

Styles short, dilated; scales thickened on the back; leaves seldom bristletipped; wood white. (White oaks.)

Acorns developing the second year; cups very thick; nuts tomentose within; leaves evergreen, tomentose beneath.

Leaves entire or spinose-toothed; branchlets not divaricate; acorns rounded at apex.

4. Q. chrysolepis.

Leaves coarsely spinose-toothed, undulate; branchlets rigid and divaricate; acorns pointed at apex.

Acorns developing the first year; nut glabrous within.

Leaves deciduous, more or less lobed; trees.

Leaves dark green above; deeply lobed or parted; cups deep; branchlets pendulous.

6. Q. lobata.

Leaves blue-green above, shallowly lobed; cups shallow; branchlets not pendulous.

7. Q. Douglasii.

Leaves evergreen.

Trees; leaves entire or shallowly lobed, not spinose-toothed.

8. Q. Engelmanni.

Shrubs; leaves usually more or less spinose-toothed.

Leaves nearly or quite glabrous above; twigs rusty-pubescent.

Cups saucer-shaped; scales thick and rounded on the back.

9. Q. dumosa.

Cup turbinate; scales thin.

10. Q. turbinella.

Leaves gray with a stellate-pubescence above; twigs grayishpubescent.

I1. Q. Alvordiana.

I. Quercus Kelloggin Newb. Pacif. R. Rep. 6: 28, f. 6. 1857. Quercus tinctoria californica Torr. Pacif. R. Rep. 4: I38. 1857. Quercus californica Cooper, Smiths. Rep. 26r. 1858.

Type locality: "South and north of San Francisco in the Coast Mountains," and "between Fort Redding and Lassen's Butte, on the western slope of the Sierra Nevada."

Distribution: Southern Oregon southward through the Coast Ranges and the Sierra Nevada to San Pedro Martir, Lower California. In southern California the California black oak is confined to the coniferous forests of the mountains, and is a characteristic tree of the Transition Zone. 
Specimens examined: Near the summit of Frazier Mountain, Dudley 4469; Water Canyon, Tehachapi Mountains, Abrams छ McGregor 480; Rock Creek Canyon, San Gabriel Mountains, Abrams \& McGregor 604; Swartout Valley, San Gabriel Mountains, Abrams छ McGregor 649; Mill Creek Falls, San Bernardino Mountains, Parish 5068; Cuiamaca Mountains, Susan G. Stokes, July, 1895; Abrams 3959 .

2. Quercus Wislizeni A. DC. Prod. 16, pt. 2: 67. 1864. Quercus Wislizeni frutescens Engelm. in Bot. Calif. 2: 99.1880. Quercus parvula Greene, Pittonia 1: 40. 1887.

Type locality: Originally given as Mexican, but later corrected (Trans. St. Louis. Acad. 3: 396. 1877) to "the American Fork of the Sacramento River," California.

Distribution: Southern slopes of Mount Shasta southward in the Coast Ranges and in the Sierra Nevada to San Pedro Martir Mountain. In southern California it occurs in the upper part of the chaparral belt of all the mountains. The shrubby form is the common type, but occasionally trees 20-25 feet high have been observed (Santa Ana Canyon, San Bernardino Mountains, and Swartout Valley, San Gabriel Mountains). Transition and Upper Sonoran.

Specimens examined; Santa Ynez Mountains, Franceschi, I894; Cuddy's ranch, near Mt. Frazier, Dudley 4366; Mount Lowe, Dudley, July 20, 1896; Red Reef Canyon, Topatopa Mountains, Abrams छ3 McGregor 152; Kings Canyon, Liebre Mountains, Dudley 4346; Swartout Valley, San Gabriel Mountain, Abrams छ McGregor 66r; Lytle Creek Canyon, Hall gor; Arrowhead grade, Shaw and Illingsworth r6; Santa Ana Canyon, San Bernardino Mountains, Shaw E Illingsworth 155; Spencer Valley, Cuiamaca Mountains, Abrams 3875; Cuiamaca Peak, Abrams 3950; Walker's ranch, near Jacumba Hot Spring, Abrams 3697.

3. Quercus agrifolia Nee, Anal. Cienc. Nat. 3: 271. 180I. Quercus oxyadenia Torr. Sitg. Rep. 172, pl. 17. 1853. Quercus berberidifolia Liebm. Oversigt Dansk. Vidensk. I854, 172. 1854 .

Quercus arcoglandis Kell. Proc. Calif. Acad. 1: 25. 1855. Quercus agrifolia frutescens Engelm. Bot. Calif. 2: 98 . I880. Quercus agrifolia berberifolia Wenzig, Jahrb. Bot. Gart. Berlin 3: 203. 1885. 
Type locality: "I have only seen branches collected at Monterey and Nootka, by the marine officer Don Robredo, and Don Manuel Esquerra, paymaster of the corvette Atrevida." The above is copied from the translation of Nee's paper in the Annals of Botany (2: 106. 1806). The station "Nootka" must be erroneous.

Distribution: Mendocino County southward through the Coast Ranges to Mt. San Pedro Martir, Lower California. In southern California this oak is confined to the coast slope, even becoming very uncommon in the interior valleys. Its most eastern station is in the mountains between Campo and Jacumba Hot Spring, San Diego County. Upper Sonoran.

Specimens examined: Sespe Hot Springs, Dudley 478I; Switzer's Camp, San Gabriel Mountains, Grinnell, Oct. 8, r908; near Julian, Susan G. Stokes, July, I895; Alpine, Cuiamaca Mountains, Mearns 3949, 4014 .

Quercus morehus Kell. This oak is apparently a hybrid between $Q$. Kelloggii and $Q$. Wislizeni. It is never found except in the vicinity of these species, and never in large numbers. Two trees have been discovered recently in southern California: between Swartout Valley and Lone Pine Canyon, San Gabriel Mountains, Abrams E McGregor 666; near Skinner's Camp, Mill Creek, San Bernardino Mountains, Abrams E McGregor 810.

4. Quercus chrysolepis Liebm. Dansk. Vidensk. Forhandl.

$$
\text { I854, I73. I } 854 \text {. }
$$

Quercus fulvescens Kell. Proc. Calif. Acad. 1: 67. 1855.

Quercus crassipocula Torr. Pacif. R. Rep. 4, pt. I: I37. 1857.

Type locality: "California."

Distribution: Southern Oregon southward through the Coast Ranges and the western slope of the Sierra Nevada to San Pedro Martir Mountain. In southern California the canyon oak occurs in the lower part of the Transition Zone and extends into the Upper Sonoran along the canyons.

Specimens examined: Kings Canyon, Liebre Mountains, Dudley 4364, 4430; Water Canyon, Tehachapi Mountains, Abrams छ McGregor 43I; Frazier Mountain, Dudley 454r; Mount Wilson trail, San Gabriel Mountains, Grinnell 9o; Talley's ranch, Cuiamaca Mountains, Susan G. Stokes, July, 1895.

Quercus tomentella Engelm. Trans. St. Louis Acad. 3: 393. 1877. Foliage resembling that of Pasania densiflora; leaves 
oblong-ovate strongly nerved and tomentose beneath. Peculiar to the islands off the coast of southern California.

5. Quercus Dunnir Kell. Pacif. Rural Press. June 7, 1879.

Quercus Palmeri Engelm. in Bot. Calif. 2: 97. 1880.

Quercus chrysolepis Palmeri Engelm. Trans. St. Louis Acad. 3:

383. 1877.

Type locality: Not ascertained.

Distribution: Mountains of southern San Diego County southward into Lower California. This oak has been reported from Vandeventer's ranch, San Jacinto Mountains, otherwise it is known within the state only in the region where it was first discovered, which is a small grove about five miles west of Jacumba Hot Spring (Larken's Station). It probably belongs to the piñon belt of the Upper Sonoran.

Specimens examined: Walker's ranch, near Jacumba Hot Spring, Abrams 3698.

6. Quercus lobata Nee, Anal. Nat. 3: 277. I80I. Quercus Hindsii Benth. Bot. Sulph. 55. 1844 .

Quercus lobata Hindsii Wenzig, Jahrb. Bot. Gart. Berlin 3: I88. 1885.

Quercus longiglanda Torr. \& Frem. in Frem. Geog. Mem. Upper

Calif. 17. 1848.

Type locality: "Of this species I have only seen branches brought from Monterey by Sres. Robredo and Esquerra." The citation given here is copied from a translation of Nee's paper in Annals of Botany (2: III. I806).

Distribution: Valleys and low hills from the upper Sacramento southward to San Fernando Valley, Los Angeles County. In southern California the roble or valley oak does not occur south of the Santa Monica, Mountains except for a single tree near Santa Monica, and another young one near Lamanda Park. North of the Santa Monica Mountains it occurs in the San Fernando, Simi, Santa Clara, and Ojai Valleys. On the desert slopes of the mountains it enters our territory through Tejon Pass and extends along the western border of Antelope Valley to the vicinity of Elizabeth Lake, Liebre Mountains. Upper Sonoran.

Specimens examined: Canyon near Castac Lake, Dudley 4469; Soldier's Camp, near Fort Tejon, Abrams $\xi 3$ McGregor 273; Oak- 
grove Canyon, Liebre Mountains, Abrams \& McGregor 825; Water Canyon, Tehachapi Mountains, Abrams E McGregor 492; Chatsworth, Abrams 1335 .

7. Quercus Douglasii Hook. \& Arn. Bot. Beech. 391. 1841.

Quercus Ransomi Kell. Proc. Calif. Acad. 1: 25. 1855.

Quercus oblongifolia brevilobata Torr. Bot. Wilkes Exped. 460. I 874 .

Type locality: "California." First collected by Douglas.

Distribution: In the foothills and valleys of the Coast Ranges and Sierra Nevada from Mendocino County and the upper Sacramento Valley to the southern slopes of the Tehachapi Mountains. Upper Sonoran.

Specimens examined: Canyon above Castac Lake, Dudley 4470, Lebec Station, near Fort Tejon, Abrams \& McGregor 285.

8. Quercus Engelmanni Greene, West. Am. Oaks $33, p l$. I5, f. 2, 3; pl. 17.1889 .

Quercus MacDonaldi elegantula Greene, W. Am. Oaks, 26, pl. 29. I 890.

Type locality: "Mountains of southern California, from the mesas east of San Diego northward to Kern County."

Distribution: Valleys and low foothills in the vicinity of Pasadena southward through western San Diego County, and probably extending into Lower California. Hybrids between this species and $Q$. dumosa often occur. Quercus MacDonaldi elegantula was based upon one of these. Upper Sonoran.

Specimens examined: San Gabriel, Engelmann, Sept. 18, I880; near Pasadena, Grinnell, Dec. 1903; Santa Anita, Grinnell 126; Sierra Madre, Abrams 1490; Fallbrook, Parish, Nov. 5, I891; Potrero, Orcutt 2209; Alpine, Mearns 3952.

Quercus MacDonaldi Greene, W. Am. Oaks 25. 1889. A species peculiar to Santa Catilina Island. Small tree with foliage much like that of $Q$. Douglasii.

9. Quercus dumosa Nutt. N. Am. Sylva 1: 7. 1842 .

Quercus acutidens Torr. Bot. Mex. Bound. 207, pl. 5I. 1859. Quercus dumosa polycarpa Greene, West Am. Oaks pt. 2, pl. 28. I 890 . 


\section{$\left(34^{8}\right)$}

Type locality: "Entangled thickets over the base of the hills which flank the village of Santa Barbara."

Distribution: Coast Ranges from Lake County southward to northern Lower California, also on the western slope of the Sierra Nevada. In southern California this is the most common shrub in the chaparral belt of the coastal mountains, but less common in the interior. On the desert slopes of the mountains it is seldom met with, being mostly replaced by the next species. As here understood the species has a great number of forms or variations, both in foliage and fruit. Upper Sonoran.

Specimens examined: Mountain Drive, near Santa Barbara, Abrams 4108; head of Santa Clara Valley, Rothrock 186; Oakgrove Canyon, Liebre Mountains, Abrams \& McGregor 332; Santa Monica Mountains Hasse, Dec. I891; Abrams 866, I285, I3II; Verdugo Hills, Abrams I4I9, I420; Arroyo Seco, near Pasadena, Grinnell, Dec. 22, 1908; Switzer's Camp, San Gabriel Mountains, Grinnell, Oct. 8, I908; Sawpit Canyon, near Monrovia, Dudley, Dec. 27, 1907; San Antonio Canyon, Baker 3684; Cajon Pass, Coville \& Funston II5; near Strawberry Valley, San Jacinto Mountains, Leiberg 3113; Santa Ana Mountains, near Elsinore, Abrams, July 21, 1908; San Joaquin Hills, near Laguna, Abrams 1784; San Dieguito (Benardo), Abrams 3377; near San Ysabel, Henshaw 227; San Diego, Abrams 4014.

io. Quercus turbinella Greene, W. Am. Oaks 37, pl. 27. I889.

Quercus dumosa turbinella Jepson, Fl. Calif. 356. 1909.

Type locality: "In the mountains of Lower California, where it is associated with the rare and characteristic $Q$. dunnii also within the borders of the State of California about Campo, in San Diego County."

Distribution: Inner South Coast Range from the Rancho Cantera southward to Frazier Mountain according to Jepson. I have seen no specimens of this species except from the vicinity of Campo, where it is very common in the chaparral-covered mountains which form the divide between the coast slope and the Colorado Desert. Upper Sonoran.

Specimens examined: Near Campo, Abrams 3552, 3553; Meikle, Nov. 1903. 
II. Quercus Alvordiana Eastwood, Handb. Trees Calif. 48, pl. 27, fig. 4. I905.

Type locality: "In the mountains connecting the Coast Range with the Sierra Nevada at the southern end of the San Joaquin Valley bordering the deserts."

Distribution: Desert slopes of the southern California mountains, extending from the Tehachapi Mountains southward into Lower California. This species may be only a form of $Q$. pungens to which it is certainly very closely related. Upper Sonoran.

Specimens examined: Frazier Borax Mine, Mount Pinos, Abrams छ McGregor 266; Oriflamme Canyon, Cuiamaca Mountains, Abrams 3935.

\section{CAStANOPSis. Chinquapin.}

I. Castanopsis sempervirens (Kell.) Dudley; Merriam, N. Am. Fauna, no. 16: 142. I899.

Castanea sempervirens Kell. Proc. Calif. Acad. 1: 75. 1855.

Type locality: "From the vicinity of Mariposa."

Distribution: Southern Cascade Mountains southward through the Sierra Nevada and the mountains of southern California, to the San Jacinto Mountains. In southern California it occupies a comparatively distinct belt in the border line between the Transition and Canadian Zones.

Specimens examined: North Baldy, Abrams \& McGregor 607; Mount San Antonio, Abrams 2712; Mount San Gorgonio, altitude 3200 meters, Abrams E McGregor 759.

\section{POLyGonaCEaE. Buckwheat Family.}

\section{ERIOGONUM. Wild Buckwheat.}

Involucres capitate or fascicled, in cymose-umbellate clusters; bracts foliaceous.

Leaves orbicular to oblong, not fascicled.

Peduncles elongated; flowers very villous.
Peduncles short; flowers glabrous.
I. E. cinereum.
2. E. parvifolium.

Leaves narrowly oblanceolate, often revolute, more or less fascicled.

Perianth glabrous without; leaves nearly so.

Perianth villous without.

3. E. fasciculatum.

Leaves green and nearly glabrous above; involucres $3 \mathrm{~mm}$. high.

3a. E. fasciculatum foliolosum. 
Leaves hoary-tomentose above; involucres $4-5 \mathrm{~mm}$. high.

3b. E. fasciculatum polifolium.

Involucres solitary, sessile along the branches; bracts not foliaceous.

Involucres tomentose.

Inflorescence virgately branched; branches slender becoming more or less denuded of tomentum.

4. E. taxifolium.

Inflorescence with spreading, stout branches, permanently and densely white-tomentose.

5. E. nodosum.

Involucres glabrous or nearly so; inflorescence intricately branched.

Leaves densely tomentose; involucral teeth villous on the margins. 6. E. Plunatella.

Leaves glabrate; involucral teeth glabrous.

7. E. Heermanni.

I. Eriogonum cinereum Benth. Bot. Sulph. 45. I844.

Type locality: "San Pedro."

Distribution: Bluffs along the seashore and in the coastal foothills of southern California from the vicinity of Santa Barbara to San Pedro. Upper Sonoran.

Specimens examined: Ventura, Hasse, Sept. I5, 1888; Santa Monica, Hasse, Sept. 1889; S. B. छ W. F. Parish, 1882; Abrams 2193.

2. Eriogonum parvifolium Smith in Rees. Cycl. 13. 18 rg.

Type locality: "California." First collected by Menzies, probably at Monterey.

Distribution: Seashore of California from Monterey to San Diego County. A common shrub on the sand-dunes. Upper Sonoran.

Specimens examined: Santa Barbara, Elmer 3908, 4013; Abrams 4r62; Santa Monica, Hasse, I 894; Playa del Rey (Ballona Harbor), Abrams 212; Oceanside, Parish 4446.

3. Eriogonum fasciculatum Benth. Trans. Linn. Soc, 17: 4 II. 1838 .

Eriogonum rosmarinifolium Nutt. Journ. Acad. Philad. II. 1: I64. 1847 .

Eriogonum fasciculatum aspalathoides Gdgr. Bull. Soc. Bot. Belg. 42: 189.1906.

Eriogonum fasciculatum maritimum Parish, Muhlenbergia 3: 59. 1907.

Type locality: "California." 
Distribution: Santa Barbara southward to northern Lower California. Apparently most abundant about San Diego. Throughout the greater part of the coastal slope of southern California the typical form is replaced by the next. Upper and Lower Sonoran.

Specimens examined: Chollas Valley, Susan G. Stokes, July 2I, Igor; Dulzura, Susan G. Stokes, July 17, I90I; San Diego, Herre, July 5, I902; Tia Juana, Abrams 3519.

\section{3a. Eriogonum fasciculatum foliolosum (Nutt.) Stokes.}

Eriogonum rosmarinifolium foliolosum Nutt. Journ. Acad. Philad.

II. 1: $164 . \quad$ I 847 .

Type locality: "Near Santa Barbara Upper California."

Distribution: A very common shrub in the lower altitudes of the chaparral belt on the coastal slope, extending from the vicinity of Santa Barbara to Lower California. Upper and Lower Sonoran.

Specimens examined: Mountain Drive, near Santa Barbara, Abrams 4I26; Oakgrove Canyon, Liebre Mountains, Abrams छ McGregor 389 ("Growing with the variety polifolium and apparently not intergrading"); Pasadena, Jones 3019; Sierra Madre, Abrams 2643; San Gabriel Canyon, Abrams ro48; Lone Pine Canyon, San Gabriel Mountains, Abrams \& McGregor 679 (intermediate between this variety and the next); vicinity of San Bernardino, Parish 538; Banning, Toumy, Sept. 27, I894; Santiago Canyon, Santa Ana Mountains, Helen D. Geis 524; Elsinore, Mrs. J. D. Abrams, May, Igor.

3b. Eriogonum fasciculatum polifolium (Benth.) Torr. \& Gray, Proc. Am. Acad. 8: 169. 1870.

Eriogonum polifolium Benth. in DC. Prod. 14: 12. 1857.

Type locality: "In Sierra Nevada, California (Fremont), and San Diego (Parry)."

Distribution: On the desert slopes of all the mountains of Southern California mostly within the piñon belt, and occasionally occurring in the more arid interior parts of the coast slope. Upper and Lower Sonoran.

Specimens examined: Vicinity of Fort Tejon, Abrams छ McGregor 29I; Red Reef Canyon, Topatopa Mountains, Abrams छ McGregor 134; Willow Springs, Mohave Desert, Abrams छ McGregor 420; Oakgrove Canyon, Liebre Mountains, Abrams छ 
McGregor 324; Rock Creek, desert slope of the San Gabriel Mountains, Abrams है McGregor 549.

4. Eriogonum taxifolium Greene, Pittonia 1: 267. 1889. Eriogonum Wrightii taxifolium Parish, Erythea 6: 87. 1898.

Type locality: Cedros Island, "from a canyon on the eastern side, four miles below the northern end."

Distribution: San Jacinto Mountains southward to Cedros Island. Upper and Lower Sonoran.

Specimens examined: Cuiamaca Mountains, Parry 1850; Allen, I897; Miss Stokes, Aug. 4, I899; Jacumba Hot Spring (Larkens), Palmer 343; near Warner ranch, Hayes, Oct. ro, I858; open pine forests in the vicinity of Strawberry Valley, San Jacinto Mountains, altitude 1700-2000 meters, Hall 2608; Hemet Valley, Hall 755 .

5. Eriogonum nodosum Small, Bull. Torr. Bot. Club 25: 48. I 898.

Type locality: "In dry soil, Don Cabesas, California."

Distribution: A desert species, known only from the original collection. Lower Sonoran.

6. Eriogonum Plumatella Dur. \& Hilg. Pacif. R. Rep. 5: i4, pl. I6. 1855 .

Eriogonum Palmeri S. Wats. Proc. Am. Acad. 12: 267. 1877.

Type locality: "Posa Creek," Kern County, California.

Distribution: Mohave Desert of southern California eastward to southern Utah. In southern California this species is characteristic of the yucca belt. Lower Sonoran.

Specimens examined: Desert slope of the Tehachapi Mountains between Tehachapi and Mohave, Abrams \& McGregor 497; Palmdale, Abrams \& McGregor 515; Rock Creek, edge of Mohave Desert, Davidson, Aug. I, I90I; Mohave River, near the Hesperia, Abrams 2165.

7. Eriogonum Heermanni Dur. \& Hilg. Pacif. R. Rep. 5: i4, pl. I7. 1855 .

Type locality: "Rose Creek," California.

Distribution: Western Nevada southward through the Piñon belt to Mount Pinos. Upper Sonoran. 
Specimens examined: Frazier Borax Mine, Mount Pinos, altitude I600 meters, Abrams छ McGregor 267.

\section{Chenopodiaceae. Goosefoot Family.}

Flowers unisexual.

Staminate flowers with $3-5$-cleft perianth; pistillate flowers without perianth, enclosed in a pair of more or less united bracts.

Bracts compressed.

Bracts obcompressed.

Pericarp glabrous, winged.

Pericarp hairy, not winged.
1. Atriplex.

2. Grayia.

3. Eurotia.

Staminate flowers without perianth; pistillate with a saccate perianth.

Flowers perfect.

6. Sarcobatus.

Leaves none; flowers immersed in the fleshy stems.

Leaves terete; flowers not immersed in the stems.

4. Allenrolfea.

5. Dondia.

\section{ATRIPLEX. Salt-bush.}

Fruiting bracts without lateral wings.

Fruiting bracts without free diverging margins; leaves petioled.

Branches terete, flexuous (or slightly spinescent in no. 1 ).

Calyx-segments 5 ; bracts obscurely crenate. I. A. lentiformis.

Calyx-segments 4 ; bracts entire. $\quad$ 2. A. Breweri.

Branches distinctly angled, the ultimate divaricate and spinescent; bracts denticulate. 3 3. Aorreyi.

Fruiting bracts with free diverging margins.

Margins of bracts toothed, sides muricate. 4. A. polycarpa.

Margins of bracts entire, sides not muricate.

Leaves entire, sessile or nearly so.

Fruiting bracts 6-10 $\mathrm{mm}$. long; leaves cuneate at base.

5. A. confertifolia.

Fruiting bracts $3 \mathrm{~mm}$. long; leaves cordate at base.

Leaves coarsely toothed.

Fruiting bracts with 4 broadly dilated lateral wings.
6. A. Parryi.

7. A. hymenelytra.

8. A. canescens.

I. Atriplex lentiformis (Torr.) S. Wats. Proc. Am. Acad. 9: II8. I874.

Obione lentiformis Torr. Sitg. Rep. I69, pl. I4. I854.

Type locality: "On the Colorado of California."

Distribution: Upper San Joaquin Valley southward through the deserts of southern California, and Arizona to adjacent Mexico. Growing in heavy alkaline soil. Lower Sonoran.

Specimens examined: Imperial Valley, near Calexico, G. D. Abrams, Sept. 1902; Mountain Spring, Palmer 328. 


\section{(354)}

2. Atriplex Breweri S. Wats. Proc. Am. Acad. 9: iI9. 1874. Atriplex orbicularis S. Wats. Proc. Am. Acad. 17: 377.' 1882.

Type locality: "On the seashore at Santa Monica (Brewer) and Santa Barbara, Torrey."

Distribution: Bluffs and low places, especially in clay soil, along the seashore from Santa Barbara to northern San Diego County. Upper Sonoran.

Specimens examined: Santa Barbara Torrey 459; Elmer 40I6; Ventura, Hasse 4193; Santa Monica, Brewer, Dec. 1860, Abrams 2189.

3. Atriplex Torreyi S. Wats. Proc. Am. Acad. 9: ilg. 1874. Obione Torreyi S. Wats. Bot. King Exped. 290. I871.

Type locality: "In dry valleys bordering the Truckee and Carson Rivers," Nevada.

Distribution: Western Nevada and southern Utah to Antelope Valley, Mohave Desert, where it is common about Lancaster and Willow Springs. Lower Sonoran.

Specimens examined: Lancaster, Wells, Dec. 1909.

3. Atriplex polycarpa (Torr.) S. Wats. Proc. Am. Acad. 9: I 17.1874 .

Obione polycarpa Torr. Pacif. R. Rep. 4: 130. 1857.

Type locality: "Hills and gravely places, on William's River."

Distribution: Deserts of southern California eastward to Arizona. Lower Sonoran.

Specimens examined: Colorado Desert, Pringle, Oct. 24, 1882; Emory, Oct. 28, 1846.

4. Atriplex confertifolia (Torr. \& Frem.) S. Wats. Proc. Am. Acad. 17: I I9. I874.

Obione confertifolia Torr. \& Frem. Second Rep. 318. 1845.

Obione spinosa Moq. in DC. Prod. 13, pt. 2: 108. 1849. Atriplex spinosa Dietrich, Syn. Pl. 5: 536.1852.

Type locality: "On the borders of the Great Salt Lake."

Distribution: Southern Idaho and Wyoming south to New Mexico and northern Mexico, and eastward to the deserts of southern California. Growing in alkaline soil. Lower Sonoran.

Specimens examined: Lancaster, Elmer 369r; Abrams छै McGregor $5 I I$, Willow Springs, Abrams \& McGregor $4 I 6$. 
5. Atriplex Parryi S. Wats. Proc. Am. Acad. 17: 378. I 882. Type locality: "Near Colton, California." Parish (Zoe 5: Ir 3 ) states that "Dr. Parry's plant was collected at Lancaster, in the Mohave Desert."

Distribution: Mohave Desert, southern California. Lower Sonoran.

Specimens examined: Lancaster, Elmer 3640; Wells, Dec. 1909.

6. Atriplex hymenelytra (Torr.) S. Wats. Proc. Am. Acad. 9: II9. 1874 .

Obione hymenelytra Torr. Pacif. R. Rep. 4: I29, pl. 20. 1857. Type locality: "Hills and gravelly places, on Williams River."

Distribution: Southern Utah and Arizona westward to the desert slopes of the mountains of southern California. Growing in dry gravelly washes. Lower Sonoran.

Specimens examined: Near Bennett Wells, Death Valley, Coville E๐ Funston 195; Signal Mountain, Colorado Desert, Abrams, Dec. 29, I907; eastern slope of the Cuiamaca Mountains, Emory Nov. 28, 1846; near Mammoth Tank, Parish, Dec. Io, I88I.

7. Atriplex canescens (Pursh) Nutt. Gen. N. Am. Pl. 1: 197. I 8 I 8.

Calligonum canescens Pursh, Fl. Am. Sept. 2: 370. I8I4. Obione tetraptera Benth. Bot. Sulph. 48. 1844.

Type locality: "In the planes of the Missouri, near the Bigbend."

Distribution: Nevada and Colorado southward to New Mexico and Arizona, and westward to southern California, where it is especially common in the deserts. On the coast slope it occurs rather locally in the interior valleys toward the deserts, and in the vicinity of San Diego, mostly in dry subsaline places. Upper and Lower Sonoran.

Specimens examined: Ten Sycamore Flat, Sespe Creek, Abrams छ McGregor 167; Lancaster, Elmer 3647; between Glendale and Burbank, Braunton 906; Cushenberry Spring, Abrams 2150; San Bernardino, Parish, May, I900; near Redlands, G. R. Hall, I904; San Jacinto Valley, Hall 2003; Encinitas, Mc Clatchie, June, 1896; La Jolla, Abrams 4012; San Diego, Parry, 1850; Palmer 327; Calexico, G. D. Abrams, Sept., I902. 


\section{GRAYIA.}

I. Grayia spinosa (Hook.) Moq. in DC. Prod. 13, pt. 2: irg. I 849 .

Chenopodium spinosum Hook. Fl. Bor. Am. 2: 127. 1838.

Grayia polygaloides Hook. \& Arn. Bot. Beechy 388. I84I.

Type locality: "Interior of California, Nov. 1826; Mr. Douglas Snake country, Mr. Tolmie."

Distribution: Eastern Washington and Wyoming southward through the Great Basin to the Mohave Desert of southern California. Lower Sonoran.

Specimens examined: Near Willow Springs, Abrams E McGregor 826; Palmdale, Elmer 3613.

\section{EUROTIA.}

I. Eurotia lanata (Pursh) Moq. Chenop. Mon. Enum. 8I. 1840.

Diotis lanata Pursh, Fl. Am. Sept. 2: 602. I814.

Type locality: "On the banks of the Missouri in open prairies."

Distribution: Eastern Washington and the Saskatchewan southward to New Mexico and southern California, where it is confined to the desert districts. Lower Sonoran.

Specimens examined: Desert slopes of the Tehachapi Mountains, near Willow Springs, Abrams E McGregor 427; Palmdale, Elmer 3677; Abrams \&5 McGregor 512; near Barstow, Hall 6164.

\section{ALLENROLFEA.}

I. Allenrolfea occidentalis (S. Wats.) Kuntze, Rev. Gen. Pl. 2: 546 . 1891 .

Halostachys occidentalis S. Wats. Bot. King Exped. 5: 293. 1871. Spirostachys occidentalis S. Wats. Proc. Am. Acad. 11: I25. I 874 .

Type locality: "About Great Salt Lake and in alkaline valleys westward to the sinks of the Carson and Humboldt Rivers, where it grows luxuriantly in large tracts that would be otherwise destitute of vegetation."

Distribution: Great Basin southward to western Texas and New Mexico and westward to California. In California this species occurs in very strong alkaline or saline places from Liver- 
more southward through the upper San Joaquin Valley and the deserts of southern California.

Specimens examined: Near Lancaster, Abrams E McGregor $52 I$.

\section{DONDIA.}

I. Dondia suffrutescens (S. Wats.) Heller, Cat. N. Am. Pl. 3. 1898.

Suaeda sufrutescens S. Wats. Proc. Am. Acad. 9: 88. I 874.

Type locality: "Western Texas to southern California and northern Mexico, in saline plains."

Distribution: Saline soils along the coast of southern California, eastward to western Texas. Very common in the Colorado Desert. Upper and Lower Sonoran.

Specimens examined: Long Beach, Mc Clatchie, May 30, I89I; Chula Vista, Abrams 4I9I; North Island, Coronado, Chandler 5185 .

\section{SARCOBATUS.}

Leaves glabrous or nearly so; body of fruit $8-9 \mathrm{~mm}$. long. I. S. vermiculatus. Leaves pubescent with branched reflexed hairs; body of fruit $4-5 \mathrm{~mm}$. long. 2. S. Baileyi.

I. Sarcobatus vermiculatus (Hook.) Torr. in Emory, Notes Mil. Reconnois. I50. 1848.

Batis vermiculata Hook. Fl. Bor. Am. 2: 12. 1838 .

Fremontia vermicularis Torr. in Frem. First Rep. 95. 1843.

Type locality: "Common on the barren grounds of the Columbia and particularly near salt marshes." First collected by Douglas.

Distribution: Alkaline places in eastern Washington and Oregon, and southward through the Great Basin to Arizona and the eastern parts of California. I have not seen any specimens of this species from our range, but it is common east of the Sierra Nevada about Owens Lake. Upper and Lower Sonoran.

2. Sarcobatus Baileyr Coville, Contr. Nat. Herb. 4: i84. I893. Type locality: "In the valley near Thorpe's quartz-mill, Nye County, Nevada."

Distribution: Western Nevada and extending into the borders of California in Inyo and Mono Counties, according to Coville. This species has not been collected within our limits, but it may 
be expected along our northern borders in the Mohave Desert. Lower Sonoran.

\section{RANUNCUlaceae. Buttercup Family.}

\section{Clematis. Clematis.}

Ovaries and achenes pubescent.

Leaflets 5 ; sepals thin, 7-10 $\mathrm{mm}$. long.

Leaflets 3 ; sepals thick, $12-18 \mathrm{~mm}$. long.

Ovaries and achenes glabrous.

I. C. ligusticifolia californica.

2. C. lasiantha.

3. C. pauciflora.

I. Clematis ligusticifolia californica S. Wats. Bot. Calif. 1: 3. 1876.

Type locality: "San Diego to the Sacramento and to Arizona."

Distribution: Central California southward to the southern boundary of the State. In southern California it is found along streams in the valleys and foothills. Upper and Lower Sonoran.

Specimens examined: Santa Barbara, Bingham; Abrams 4I57; San Gabriel Mountains, Mc Clatchie, Aug. 1895; Monrovia Canyon, Dudley, Nov. 20, 1907; San Antonio Canyon, Baker 3438; Los Angeles, Abrams 4I68; Lytle Creek Canyon, Abrams 19r6; San Bernardino, Parish; Jamul Valley, Susan G. Stokes, June 19, 1895; Cajon Pass, Abrams \& McGregor 837.

2. Clematis lasiantha Nutt. in Torr. \& Gray, Fl. N. Am. 1: 9. 1838.

Type locality: "Near the sea-coast of St. Diego."

Distribution: Central California south to the southern boundary of the State. In southern California this is the most common clematis. It is frequent in the chaparral on the coast slope of all the mountains and foothills. Upper Sonoran and extending into the upper parts of the Lower Sonoran of the coastal slope.

Specimens examined: Santa Barbara, Nuttall; Elmer 3844; Montecito, Franceschi, 1894; Sulphur Mountain, Red Reef Canyon, Topatopa Mountains, Abrams है McGregor 128; Santa Monica Mountains, Abrams 1306; Mount Wilson trail, Abrams 2610; Cañon Diablo, Parish 4709; Mill Creek, Parish, June, I 898.

3. Clematis pauciflora Nutt. in Torr. \& Gray, Fl. N. Am. 1: 9. 1838 \& 1: 657 . 1840 .

Type locality: "Near the sea-coast of St. Diego." 
Distribution: Santa Barbara County southward to northern Lower California. In southern California this species is almost wholly restricted to San Diego County, where it is the common clematis. Upper and Lower Sonoran.

Specimens examined: Santa Barbara, Elmer 3906; near San Bernardino, Parish 3626; Whitewater, Vasey, Feb. I88ı; San Diego, Nuttall; Abrams 3428; Foster, Chandler 5033; Point Loma, Chandler 5088; Campo, Abrams 3612; Hill Valley, between Campo and Jacumba Hot Spring, Abrams 3736, San Ysabel, Henshaw 61.

\section{BERBERIDACEAE. Barberry Family.}

\section{ODOSTEMON. OREgON GRAPE.}

Leaflets $3-7$, I5 mm. wide or less, very pale; racemes loosely 5-7-flowered. Leaflets $15-25 \mathrm{~mm}$. long; spinose teeth $2-4$ on a side, stout.

I. O. Fremontii.

Leaflets oblong-lanceolate, $15-35 \mathrm{~mm}$. long, spinulose-serrate; teeth slender, numerous.

2. O. Nevinii.

Leaflets 5-9, 20-30 mm. broad; racemes many-flowered.

Leaflets green above, scarcely paler beneath, rather thin, spinose teeth 6-10 on a side.

3. O. fascicularis.

Leaflets much paler beneath, prominently reticulate-veined, thick and undulate; spinose teeth usually $4^{-6}$ on a side.

4. O. dictyota.

I. Odostemon Fremontii (Torr.) Rydb. Bull. Torr. Bot. Club 33: I4I. 1906.

Berberis Fremontii Torr. Bot. Mex. Bound. 30. I 859 .

Mahonia Fremontii Fedde, Engl. Bot. Jahrb. 31: 98. r9or.

Type locality: "On the tributaries of the Rio Virgen, in southern Utah."

Distribution: Southern Utah and Nevada southward to Arizona, also in southern California and northern Lower California. In southern California this species has only been collected near the southern boundary. Upper Sonoran.

Specimens examined: Walker's ranch, near Jacumba Hot Spring, Abrams 3693.

\section{Odostemon Nevinii (A. Gray).}

Berberis Nevinii A. Gray, Syn. Fl. 1, pt. I: 69. 1895.

Mahonia Nevinii Fedde, Engel. Bot. Jahrb. 31: I02. I90I.

Type locality: "Southern California, near Los Angeles on a sandy plain." 
Distribution: A rare species apparently confined to the San Fernando Valley, where it occurs sparingly on the sandy slopes along the eastern edge of the valley. Upper Sonoran.

Specimens examined: "Los Angeles Valley," probably San Fernando Valley, Nevin, April, r882; San Fernando, Franceschi, I893; wash near Garnsey, San Fernando Valley, Grinnell, Oct. 3I, 1903.

\section{Odostemon fascicularis (DC.).}

Mahonia fascicularis DC. Syst. 2: I9. I82I.

Berberis pinnata Lag. Elench. Hort. Madr. 6. I803, and I4. I8I6, nom. nudum.

Berberis pinnata Don, Bot. Reg. 9: pl. 702. I823. Not H.B.K. I82I.

Berberis fascicularis Sims, Bot. Mag. 50: pl. 2396. 1823. Mahonia pinnata Fedde, Engl. Bot. Jahrb. 31: 86. I9or.

Type locality: "In Americae borealis ora occidentalis circa Monterei et Nutka (Nee ex Lag.)."

Distribution: Foothills of central California from the vicinity of San Francisco to Monterey. The specimens cited below are doubtfully referred to this species, more complete material may prove them distinct.

Specimens examined: Near Glendale, Hasse; canyon near San Rafael, Hasse 3762; Switzer's trail, San Gabriel Mountains, Grinnell, Oct. 8, 1908.

\section{Odostemon dictyota (Jepson).}

Berberis dictyota Jepson, Bull. Torr. Bot. Club 18: 319. I891. Mahonia dictyota Fedde, Engl. Bot. Jahrb. 31: 89. I90I.

Type locality: "Near the rocky summit of South Peak," Marysville Buttes.

Distribution: The dry interior foothills of central California southward to San Diego County. Growing in chaparral but rare and seldom met with. Upper Sonoran.

Specimens examined: Lone Pine Canyon, San Gabriel Mountains, Abrams \& McGregor 667; Palomar Mountain, Susan G. Stokes, July, I895; between Julian and Cuiamaca, Abrams 3964 . 
LAURACEAE. Laurel Family.

I. UMbellularia. California laurel or Bay-tree.

i. Umbellularia califorica (Hook. \& Arn.) Nutt. N. Am. Sylva 1: $87 . \quad$ I 842 .

Tetranthera californica Hook. \& Arn. Bot. Beech. I59. I833. Oreodaphne californica Nees, Syst. Laurin. 463. 1836.

Type locality: California, probably in the vicinity of San Francisco or Monterey.

Distribution: Valley of the Rogue River, Oregon, southward through the Coast Ranges and on the western slope of the Sierra Nevada to the mountains of San Diego County. In southern California the laurel is frequent in canyons or on shaded slopes in the upper part of the chaparral belt and in the lower Transition, but is usually reduced to a small tree or arborescent shrub.

Umbellularia is one of the many genera peculiar to the California Sub-area, and is a good example of the uniqueness of the flora.

Specimens examined: Mission Canyon, Santa Barbara, Abrams, March 6, 1909; Red Reef Canyon, Topatopa Mountains, Abrams छ McGregor 817; Switzer's Camp, San Gabriel Mountains, Grinnell, Oct. 8, 1908; Falls Canyon, San Gabriel Mountains, Dudley, Dec. 26, 1907; Little Santa Anita Canyon, Abrams, July, 1906; Nobles ranch, between Pine Valley and Laguna, San Diego County, Mearns 3958 .

\section{PAPAVERACEAE. Poppy Family.}

Flowers yellow; leaves more or less serrulate; stigmas 2. I. Dendromecon. Flowers white and very showy; leaves divided; stigmas several.

2. Romneya.

I. DENDROMECON. BUSH POPPY.

I. Dendromecon rigidum Benth. Trans. Hort. Soc. II. 1: 407. I834.

Dendromecon fastigiata Greene, Pittonia 5: 298. 1905.

Dendromecon agnina Greene, Pittonia 5: 299. 1905.

Dendromecon saligna Greene (?), Pittonia 5: 300.1905.

Dendromecon elliptica Greene, Pittonia 5: 300.1905.

Dendromecon caesia Greene, Pittonia 5: 303. 1905.

Type locality: California. 
Distribution: Coast Ranges or central California and the western slope of the Sierra Nevada, southward through the chaparral belt to northern Lower California. The species proposed by Greene do not seem valid, at least so far as the plants of the mainland are concerned. I have examined critically all the species enumerated above except $D$. saligna with the result that I feel constrained to reduce them to synonymy. There is variation in foliage, but this is often marked in a locality where the character of the soil or moisture vary, and seems to be an ecological variation.

Specimens examined: Santa Ynez Mountains, Elmer 3875; Red Reef Canyon, Topatopa Mountains, Abrams \& McGregor 138; Big Tejunga Wash, Abrams 1373; near Elizabeth Lake, Abrams E McGregor 40I; vicinity of San Bernardino, Parish 4835; Claremont, Baker 4I50, Waterman Canyon, San Bernardino Mountains, Parish 3474; Lone Pine Canyon, San Gabriel Mountains, Abrams \& McGregor 675; Fallbrook, Jones 3103; Soledad Canyon, Greene, May 18, 1885; Encinitas, Brandegee, June, I887; Jamul Valley, Palmer 238; Campo, Vasey I8; Jacumba Hot Spring, Mearns 335I; Julian, Susan G. Stokes, July 26, 1895.

\section{ROMNEYA. Matilija POPPY.}

Sepals glabrous, beaked.

Sepals hispid, beakless or with an inconspicuous beak.
I. R. Coulteri.

2. R. trichocalyx.

I. Romneya Coulteri Harv. Hook. Lond. Journ. Bot. 4: 75, pl. 3. 1845 .

Type locality: "In California boreali."

Distribution: Santa Ana Mountains, southward to northern Lower California. Upper Sonoran.

Specimens examined: Trabuco Canyon, Santa Ana Mountains, Abrams 1852; near Corona, Hall 1280; Santa Ana Canyon, near Anaheim, Parish 393; Temescal, Parish 4394. This species and the next are not true shrubs, but the stout stems, which often attain a height of 2 meters, persist for a number of years.

2. Romneya trichocalyx Eastw. Proc. Calif. Acad. III. 1: I33, pl. $I I, f .4 a, 4 c . \quad 1898$.

Type locality: The figures "were drawn from fresh specimens [cultivated] in Golden Gate Park," San Francisco. 
Distribution: Santa Barbara County southward to northern Lower California. Upper Sonoran.

Specimens examined: Griffens, Elmer 3876 ; Ten Sycamore Flat, Sespe Creek, Abrams Eं McGregor I37; Haven's ranch, near El Nido, Abrams 3544 .

BRASSICACEAE. Mustard Family.

I. LEPIDIUM. Peppergrass.

I. Lepidium Fremonti S. Wats. Bot. King. Exped. 30, pl. 4, f. 3, 4. 1871 .

Type locality: "Gathered by Fremont on the Mohave River in I 844, and now collected on sandy foothills near Humboldt Sink."

Distribution: Nevada and Utah south to Arizona and the Mohave Desert of southern California, where it is common in the juniper belt. Upper and Lower Sonoran.

Specimens examined: Desert slopes of the Tehachapi Mountains, near Willow Springs, Abrams \& McGregor 4I5; between Tehachapi and Mohave, Abrams Eं McGregor 502; Randsburg, Heller $7679 a$.

CAPPARIDACEAE. Caper Family.

I. ISOMERIS. BLADDERPOD.

Capsule strongly inflated.

Capsule attenuate at base.

I. I. arborea.

Capsule globose, not attenuate at base.

Capsule scarcely inflated, oblong, attenuate at both ends.

Ia. I. arborea globosa.

Ib. 1. arborea angustata.

I. Isomeris arborea Nutt. Torr. \& Gray, Fl. N. Am. 1: I24. 1838 .

Cleome Isomeris Greene, Pittonia 1: 200. 1888.

Type locality: "St. Diego."

Distribution: Vicinity of Mount Pinos southward, especially on the margins of the deserts, to Lower California. On the coast slope it is common about San Diego and occurs on the bluffs along the sea as far northward as Playa del Rey, near Santa Monica.

Specimens examined: Griffens, Lockwood Valley, Elmer 3888; Playa del Rey, Abrams 2509; La Jolla, Chandler 5002; San Diego, Dunn, March I7, I891; Susan G. Stokes, June 4, I895; Abrams 3524 . 
ia. Iomeris arborea globosa Coville, Proc. Biol. Soc. Wash. 7: 73. I 892.

Isomeris globosa Heller, Muhlenbergia 2: 50.1905.

Type locality: "On Caliente Creek, a few miles above Caliente, Kern County, California."

Distribution: Upper end of the San Joaquin Valley in the vicinity of Caliente westward to the boundary of San Luis Obispo and Santa Barbara Counties, and also on the Sespe Creek in Ventura County. There is considerable variation of the type form in the vicinity of San Diego, and on the desert slopes the two apparently intergrade.

Specimens examined: Sespe Creek, near Ten Sycamore Flat, Abrams $\&$ McGregor 177; vicinity of Fort Tejon, Abrams छ $M c$ Gregor 280.

Ib. Isomeris arborea angustata Parish, Muhlenbergia 3: I28. 1907.

Type locality: "About Palm Springs and Whitewater."

Distribution: Mohave and Colorado Deserts also on Cedros Island (Anthony 7). Lower Sonoran.

Specimens examined: Desert slope of Tehachapi Pass, Abrams E McGregor 504.

HYDRANGEACEAE. HydRANGeA FAMily.

I. PHILADELPHUS. SYringa.

I. Philadelphus pumilus Rydb. N. Am. Fl. 22: I73. I905.

Type locality: "In rocky places, San Jacinto Mountains, southern California, at an altitude of 2500 meters."

Distribution: According to Hall this wild syringa is very common among rocks in the upper parts of the Transition from Lake Surprise to the head of Round Valley, San Jacinto Mountains, and "is most plentiful on ridges overlooking the Colorado Desert at $8000-9000 \mathrm{ft}$. alt., where the low bushes, covered with profusion of white flowers, are very conspicuous on the rocky walls in August."

Specimens examined: Vicinity of Tamarack Valley, San Jacinto Mountains, Hall 2500. 


\section{GROSSUlaRIACEAE. Gooseberry Family.}

Pedicels jointed beneath the ovary; nodal spines none or when present hypanthium not apparent.

I. Ribes.

Pedicels not jointed; nodal spines present; hypanthium evident.

2. Grossularia.

\section{RibeS. Currant.}

Stems armed with spines and bristles; hypanthium saucer-shaped.

Stems without spines or bristles.

I. R. montigenum.

Calyx smooth, yellow; leaves involute in bud.

Calyx pubescent, not yellow; leaves plicate in bud.

2. R. gracillimum.

Leaves evergreen; holly-like.

Leaves deciduous, not holly-like.

3. R. oiburnifolium.

Bracts herbaceous, toothed; flowers greenish or pinkish white.

Bracts scarious, entire or ciliate.

4. R. cereum.

Style glabrous; ovary with only gland-tipped hairs.

5. R. nevadense.

Style villous below; ovary canescent.

Flowers pink or purple, 8-10 $\mathrm{mm}$. long.

6. R. malvaceum.

Flowers white or greenish-white, 5-7 mm. long.

7. R. indecorum.

I. Ribes montigenum McClatchie, Erythea 5: $38 . \quad$ i 897.

Ribes lacustre molle A. Gray, Bot. Calif. 1: 206. 1876.

Ribes nubigenum McClatchie, Erythea 2: 80. 1894. Not Philippi, 1857.

Ribes lacustre lentum M. E. Jones, Proc. Calif. Acad. II. 5: 68I. I895.

Ribes molle Howell, Fl. NW. Am. 1: 209. 1898. Not Poepp. 1858.

Ribes lentum Coville \& Rose, Proc. Biol. Soc. Wash. 15: 28. 1902.

Type locality: "Summit of Mt. San Antonio, Io,000 ft. altitude, among dry exposed rocks."

Distribution: High mountains of the arid regions from eastern Washington and Montana southward to southern California and New Mexico. Canadian Zone.

Specimens examined: Mount Pinos, Elmer 40ro; Mount San Antonio, Mc Clatchie, Aug. 16, I893; Mount San Gorgonio, near the summit, Abrams \& McGregor 746 . 
2. Ribes gracillimum Coville \& Britton, N. Am. Fl. 22: 205. 1908.

Type locality: "Stanford University, California."

Distribution: Foothills of the Coast Ranges and the Sierra Nevada of central California southward to southern California. This species has been referred to $R$. aureum or $R$. tenuiflorum in the California manuals. Upper Sonoran.

Specimens examined: Eaton's Wash, near Sierra Madre, Abrams I49I; Glendora, Baker 4 I54.

3. Ribes viburnifolium A. Gray, Proc. Am. Acad. 17: 202. 1882.

Type locality: "Northern part of Lower California near All Saints Bay."

Distribution: Islands off the coast of southern California, and on the mainland from the vicinity of Del Mar, San Diego County southward to All Saints Bay, Lower California. Upper and Lower Sonoran.

Specimens examined: Santa Catalina Island, Miss Merritt, April, 1894; Brandegee, May 12, 1894.

4. Ribes cereum Dougl. Trans. Hort. Soc. 7: 5 I2. 1830.

Cerophyllum Douglasii Spach, Hist. Veg. 6: 153.1838. Ribes balsamiferum Kell. Proc. Calif. Acad. 2: 94. I86r.

Type locality: "On the dry exposed granite rocks or schist, throughout the chain of the river Columbia from Great Falls, $45^{\circ}$ $46^{\prime} 17^{\prime \prime}$ N. Lat. to the source of that stream in the Rocky Mountains, $52^{\circ} \circ 7^{\prime} \circ 9^{\prime \prime} . "$

Distribution: Southern British Columbia southward through the Rocky Mountains and along the Pacific Coast to the higher mountains of southern California. Canadian Zone.

Specimens examined: Mount Pinos, Elmer 3987; Abrams छ McGregor 235; North Baldy, San Gabriel Mountains, Abrams छै McGregor 619; near the summit of Mount San Antonio, Leiberg 3354; Abrams 1937, 2707; Huston Flat, San Bernardino Mountains, Shaw छ Illingsworth 106; Tahquitz Valley, San Jacinto Mountains, Hall 2350; San Jacinto Mountains, Hasse, July 2, r 892.

5. Ribes nevadense Kell. Proc. Calif. Acad. 1: 63. I 855. Ribes Grantii Heller, Muhlenbergia 4: 27. 1908.

Type locality: No locality given with the original description, 
but according to the label on a drawing of this species by $\mathrm{Dr}$. Kellogg it was "from a specimen furnished by Mr. Garvett of Placerville."

Distribution: Southern Cascade Mountains southward through the Transition Zone of the Sierra Nevada to the mountains of southern California. Growing in moist places and along streams.

Specimens examined: Mount Pinos, Abrams Eै McGregor 257; Mount Wilson, Abrams 2583; Grant, May 17, 1904; Swartout Valley, San Gabriel Mountains, Abrams E McGregor 65I; Bear Valley, Parish 3107; Huston's Flat, San Bernardino Mountains, Shaw छ Illingsworth ro6.

6. Ribes malvaceum Smith, in Rees Cycl. 30, no. I3. I8I5. Ribes malvaceum viridifolium Abrams, Bull. S. Calif. Acad. 1: 67. 1902.

Ribes viridifolium Heller, Muhlenbergia 1: 77. 1904. Ribes purpurascens Heller, Muhlenbergia 4: 29. 1908.

Type locality: "Gathered in California by Mr. Menzies."

Distribution: Foothills of the Coast Ranges of central California southward to Lower California. The specimens south of Santa Barbara vary considerably from the typical form and were described ( $R$. malvaceum viridifolium) as a variety, a disposition that may prove more logical than the present one which I have adopted from Coville \& Britton: Upper Sonoran.

Specimens examined: Mission Canyon, near Santa Barbara, Abrams, March 6, 1909; Santa Monica Mountains, Brewer 69; Abrams 1313; Cahuenga Pass, Brewer 183; Mount Wilson, on the Pasadena trail, altitude II00 meters, Abrams 1525; Santa Anita Canyon, San Gabriel Mountains, Grinnell I03; City Creek, San Bernardino Mountains, Parish, April 14, 1906.

7. Ribes indecorum Eastwood, Proc. Calif. Acad. III. 2: 243. 1902.

Ribes malvaceum indecorum Jancz. Mem. Soc. Geneve 35: 325. 1907.

Type locality: "At Cajon Heights, near San Diego, California." Distribution: In the chaparral belt of the mountains of Ventura County southward to the international boundary, and probably extending into adjacent Lower California. Upper Sonoran.

Specimens examined: Sulphur Mountain, near Santa Paula, 
Abrams E McGregor 35; San Fernando Valley, Brewer 200; Arroyo Seco Canyon, San Gabriel Mountains, Grinnell I8; Grant 793; Claremont, Baker 5238; Lone Pine Canyon, San Gabriel Mountains, Abrams \& McGregor 673; Whitewater, Vasey, I881; Toro Mountains, altitude 1300 meters, Leiberg 3166; San Ysabel, Henshaw 212; Fallbrook, Jones 3102; Oriflamme Canyon, Cuiamaca Mountains, Abrams 3936; Cajon Heights, Eastwood, March I4, 1891; Potrero, Abrams 355I; Ramona, Brandegee, March, 1906.

\section{GROSSULARIA. Gooseberry.}

Flowers 5-merous.

Berry armed with prickles.

Herbage glandular-pubescent; prickles gland-tipped.

I. G. amara.

Herbage not glandular-pubescent; prickles stiff, not gland-tipped.

Leaves shiny, minutely and sparsely pubescent; calyx-lobes twice the length of the tube.

2. G. hesperia.

Leaves canescent; calyx-lobes equaling the tube.

Berry without prickles, glabrous or pubescent.

3. G. Roezli.

Styles glabrous; flowers yellow.

Herbage glandular-pubescent; berries yellow.

4. G. velutina.

Herbage puberulent, not glandular; berries red.

Styles pubescent below; flowers purple.

5. G. quercetorum.

6. G. Parishii.

Flowers 4-merous, bright red and showy.

7. G. speciosa.

I. Grossularia amara (McClatchie) Coville \& Britton, N. Am. Fl. 22: $216 . \quad$ I 908.

Ribes amarum McClatchie, Erythea 2: 79. 1894.

Type locality: "Shaded canyons of the San Gabriel Mountains."

Distribution: On shaded canyon slopes in the chaparral belt from the southern Sierra Nevada southward through the mountains of southern California to the San Bernardino Mountains. Upper Sonoran.

Specimens examined: Near Santa Barbara, Elmer 3753; Abrams, March 6, I909; San Gabriel Mountains, near Pasadena, Mc Clatchie, March, I896; Millards Canyon, San Gabriel Mountains, Abrams, March, I899; Mount Wilson trail, altitude 700 meters, Abrams I508; Cañon Diablo, San Bernardino Mountains, Parish, July, I90I; San Antonio Canyon, San Gabriel Mountains, Baker $4^{064}$. 
2. Grossularia hesperia (McClatchie) Coville \& Britton, N. Am. Fl. 22: 215. 1908.

Ribes hesperium McClatchie, Erythea 2: 79. I894.

Ribes occidentale hesperium Jancz. Mem. Soc. Geneve 35: 68. 1907.

Type locality: "Common in shaded canyons of the San Gabriel Mountains."

Distribution: In the chaparral belt from the mountains of Ventura County southward to the San Gabriel Mountains.

Specimens examined: Sulphur Mountains Spring, near Santa Paula, Abrams \& McGregor 8; Santa Monica Mountains, Brewer 72; Sepulveda Canyon, Santa Monica Mountains, Abrams 250, 319, 2562; Santa Monica Canyon, Abrams 1477; San Gabriel Mountains near Pasadena, Mc Clatchie, Jan., I894; Cahuenga Pass, Brewer 184; Eaton's Canyon, San Gabriel Mountains, Braunton 75I; Santa Anita Canyon, Grinnell ror.

3. Grossularia Roezli Regel, Gartenflora 28: 226. 1879.

Ribes amictum Greene, Pittonia 1: 69. 1887.

Ribes aridum Greene, Pittonia 4: 35. 1889 .

Ribes Wilsonianum Greene, Erythea 3: 70. 1895 .

Type locality: Western North America.

Distribution: Southern Sierra Nevada southward through the mountains of southern California. This species occurs most abundantly in the arid parts of the Transition Zone and in the higher altitudes of the Upper Sonoran in the interior foothills.

Specimens examined: Water Canyon, Tehachapi Mountains, Abrams \& McGregor 48I; Fort Tejon, Abrams छ McGregor 296; Mount Pinos, Elmer 38 Ir; summit of Hines Peak, Topatopa Mountains, Abrams \& McGregor 79; Mount Gleason, Elmer 4249; North Baldy, San Gabriel Mountains, Abrams \& McGregor 606; Mount San Antonio, Abrams 2713; Leiberg 3357; Mount Santiago, Santa Ana Mountains, Abrams 1833; Middle Peak, Cuiamaca Mountains, Abrams 3860; Palomar Mountain, Parish 4404.

4. Grossularia velutina (Greene) Coville \& Britton, N. Am. Fl. 22: 220. 1908.

Ribes leptanthum brachyanthum A. Gray, Bot. Calif. 1: 205.8176. Ribes velutinum Greene, Bull. Calif. Acad. 1: 83. 1885. 
Ribes brachyanthum Card, Bush Fruits 460.1898.

Ribes glanduliferum Heller, Muhlenbergia 2: 56.1905.

Ribes Stanfordii Elmer, Bot. Gaz. 41: 315. 1906.

Type locality: "Open grounds in the northern part of California and the region adjacent."

Distribution: Eastern Oregon and Utah southward to northern Arizona and southern California. Transition.

Specimens examined: Mount Pinos, Elmer 3958.

5. Grossularia Quercetorum (Greene) Coville \& Britton, N. Am. Fl. 22: 220. 1908.

Ribes quercetorum Greene, Bull. Calif. Acad. 1: 83. 1885.

Ribes Congdoni Heller, Muhlenbergia 1: I0I. I904.

Ribes leptanthum quercetorum Jancz. Mem. Soc. Geneve 35: $38 \mathrm{I}$.

1907.

Type locality: "El Paso de Robles [California]."

Distribution: Southern Monterey County and Mariposa County southward to the Liebre Mountains in Los Angeles County. In southern California this species is confined to the vicinity of Fort Tejon, extending southward on the hills bordering the western part of Antelope Valley to Oakgrove Canyon, Liebre Mountains. Upper Sonoran.

Specimens examined: Fort Tejon, Abrams \& McGregor 294; Oakgrove Canyon, Liebre Mountains, Abrams \& McGregor 319 .

6. Grossularia Parishis (Heller) Coville \& Britton, N. Am. Fl. 22: 224. 1908 .

Ribes Parishii Heller, Muhlenbergia 1: 134. 1906.

Type locality: "San Bernardino Valley, San Bernardino County, California, altitude rooo feet."

Distribution: The two stations given below are the only localities where this species has been noted. It is related to G. divaricatum which has been reported from Santa Barbara County, but that is less pubescent and has the stamens exceeding instead of equaling the calyx-lobes. Upper Sonoran.

Specimens examined: Oak Knoll, near Pasadena, McClatchie, Feb. I0, I894; near San Bernardino, Vasey, I88I; Parish 600I; and April I4, 1906. 


\section{(37I)}

7. Grossularia speciosa (Pursh) Coville \& Britton, N. Am. F1. 22: 212 . 1908.

Ribes speciosum Pursh, Fl. Am. Sept. 73I. I8I4.

Robsonia speciosa Spach, Hist. Veg. 6: I8I. 1838.

Type locality: "On the north-west coast." First collected by Menzies, probably at Monterey.

Distribution: Foothills of the Coast Ranges from Monterey County south to San Diego. In southern California this species is chiefly confined to the Coastal Sub-district. Upper Sonoran.

Specimens examined: Mission Canyon, Santa Barbara, Abrams, March 6, I909; Sepulveda Canyon, Santa Monica Mountains, Abrams 2563, 3118; Sherman, Braunton 362; Eagle Rock Canyon, near Pasadena, Braunton I80; Twin Oaks, Bailey 306; Oceanside, Parish 4456; San Diego, Dunn, March 21, I891.

\section{PlatanaCeae. Plane-tree Family.}

I. Platanus. Sycamore or Plane-tree.

I. Platanus racemosa Nutt. N. Am. Sylva 1: 47 . 1842. Platanus californica Benth. Bot. Sulph. 54. I 844 .

Type locality: "A native of Upper California, in the vicinity of Sta. Barbara."

Distribution: From the lower Sacramento Valley and the inner Coast Ranges southward to northern Lower California. In southern California this species is common along streams and on canyon floors in the mountains to altitudes of 600 meters, or occasionally, on the desert slopes, extending to 1200 meters. Upper Sonoran.

Specimens examined: Santa Barbara, Elmer 383I; Sulphur Mountain Spring, near Santa Paula, Abrams E̋ McGregor 6r; Ten Sycamore Flat, Sespe Creek, Abrams \& McGregor 165; Rock Creek, desert slopes of the San Gabriel Mountains, Abrams E McGregor 529; Santa Monica Mountains, Abrams 1253; between Los Angeles and Pasadena, Abrams, March, 1899; San Gabriel, Cox, March 28, I908; Alpine, Mearns 4035; Sweetwater Valley, Susan G. Stokes, July, I 895 .

\section{CROSSOSOMATACEAE. Crossoma Family.}

\section{CROSSOSOMA.}

Petals broadly obovate or orbicular-obovate; follicles many-seeded.

Petals spatulate to oblong; follicles few-seeded.

I. C. californicum.

2. C. Bigelovii. 
I. Crossosoma Californicum Nutt. Jour. Acad. Phila. II. 1: 50. 1848 .

Type locality: Santa Catalina Island.

Distribution: This insular species has been found on Santa Catalina, San Clemente, and Guadalupe Islands, but not on the mainland. It is included for comparison and on account of its botanical interest.

2. Crossosoma Bigelovil S. Wats. Proc. Am. Acad. 11: i22. 1876.

Type locality: "In canyons near the south of Bill Williams River, W. Arizona."

Distribution: Northwestern Arizona and adjacent California southward to Lower California. Lower Sonoran.

Specimens examined: White-water S. B. छ W. F. Parish Io; no locality, Parry E Lemmon 4; Palm Springs, Parish 4105.

\section{ROSACEAE. Rose FAMILy.}

Carpels becoming drupelets in fruit.

Receptacle conical; stems prickly.

Receptacle flat; stems not prickly.

3. Rubus.

4. Rubacer.

Carpels becoming dry achenes or 2-seeded follicles.

Hypanthium not fleshy.

Styles elongated and plumose in fruit.

Calyx 5-parted; leaves alternate.

Petals present; flowers showy, terminal on short or elongated peduncles; leaves small, lobed.

Sepals with alternate linear bractlets.

Sepals without bractlets.

5. Fallugia.

6. Cowania.

Petals none; flowers small, axillary; leaves toothed or entire.

7. Cerocarpus.

Calyx 4-parted; leaves opposite.

9. Coleogyne.

Styles not becoming long and plumose in fruit; petals present.

Leaves opposite.

I. Lyonothamnus.

Leaves alternate.

Flowers paniculate or racemose; leaves simple.

Leaves plain, toothed above the middle.

Leaves terete, rarely obscurely toothed.

2. Sericotheca.

8. Adenostoma.

Flowers corymbose or solitary.

Leaves I-5-cleft; flowers solitary. Io. Kunzia. 
Leaves 3-pinnate; flowers corymbose.

II. Chamaebatia.

Hypanthium fleshy, becoming bright-colored and pome-like in fruit.

12. Rosa.

\section{r. LYONOTHAMNUS.}

I. Lyonothamnus floribundus A. Gray, Proc. Am. Acad. 20: 292. 1885 .

Lyonothamnus asplenifolius Greene, Bull. Calif. Acad. 1: 187. I 885 .

Type locality: "Santa Catalina Island."

Distribution: This monotypic genus is restricted to the islands off the coast of southern California, where it has been found on Santa Cruz, Santa Catalina, and San Clemente. Although this species has not been found on the mainland it is included on account of its botanical and horticultural interest.

\section{SERICOTHECA.}

Inforescence ample, well-compound; leaves $3-6 \mathrm{~cm}$. long. I. S. franciscana. Inflorescence small and narrow, simple, racemose, or with a few short branches; leaves $\mathrm{I}-\mathrm{I} .5 \mathrm{~cm}$. long.

2. S. concolor.

I. Sericotheca franciscana Rydb. N. Am. Fl. 22: 262.1908. Type locality: "San Leandro, California."

Distribution: Coast Ranges of central California southward to the vicinity of Los Angeles. Humid Transition and Upper Sonoran.

Specimens examined: Griffith Park, near Los Angeles, Braunton 462.

2. Sericotheca concolor Rydb. N. Am. Fl. 22: 264. 1908. Spiraea discolor dumosa S. Wats. Bot. Calif. 1: 170. I876, in part. Holodiscus discolor dumosa S. Wats.; Abrams, Fl. Los Angeles 196. I904.

Type locality: "Mt. Davidson, Nevada."

Distribution: Western Nevada and adjacent California, southward through the higher mountains of southern California. Canadian Zone.

Specimens: Mount Pinos, on the summit, Abrams E McGregor 234; Mount San Antonio, near the summit, Abrams I9I7; Green Valley, San Bernardino Mountains, Hall $I_{3} I I$; near the summit of Mount San Gorgonio, Abrams E McGregor 756; Tahquitz Valley, San Jacinto Mountains, Hall 2465. 


\section{(374)}

3. RUBUS. BRAmble.

Drupelets separating from the receptacle in fruit.

I. Rubus leucodermis. Drupelets persistent on the receptacle.

2. Rubus vitifolius.

I. Rubus leucodermis Dougl.; Hook. Fl. Bor. Am. 1:178. 1833.

Type locality: "North-West Coast America."

Distribution: British Columbia south to Wyoming and the mountains of southern California. Transition.

Specimens examined: Mount Wilson, Abrams 2584; North Baldy, San Gabriel Mountains, Abrams \& McGregor 6I7; Mill Creek Falls, Parish 5046.

2. Rubus vitifolius Cham. \& Sch. Linnaea 2: 10. I827.

Type locality: "Ad San Francisco Californiae reperimus."

Distribution: Coast Ranges of central California south to the southern boundary of the State. Upper Sonoran.

Specimens examined: Santa Barbara, Elmer 378I; Sulphur Mountain, Abrams Eं McGregor 22; Pasadena, Jones, I882; Santa Monica Mountains, Abrams 1309; Palomar Mountain, altitude I 500 meters, Susan G. Stokes, July 21, 1895; San Diego, Parry, I850.

4. RUBACER. Thimble Berry.

I. Rubacer velutinuai (Hook. \& Arn.) Heller, Muhlenbergia 1: 106. 1904.

Rubus velutinus Hook. \& Arn. Bot. Beech. 140. 1832. Rubus Nutkanus velutinus Brewer, Bot. Calif. 1: I72. 1876.

Type locality: "A native of San Francisco," California.

Distribution: Coast Ranges and the Sierra Nevada south to San Pedro Martir Mountain, Lower California. Transition and Upper Sonoran.

Specimens examined: Fremont's Pass, Santa Ynez Mountains, Mrs. M. Marshall, July, I907; Job's Peak, San Bernardino Mountains, Parish 2367; Palomar (Smith) Mountain, Susan G. Stokes, July $28, \mathbf{1} 895$.

\section{FALLUGIA.}

r. Fallugia paradoxa (Don) Endl.; Torr. Emory, Notes Mil. Reconnois. I40. I848.

Sieversia paradoxa Don, Trans. Linn. Soc. 14: 576, pl. 22, figs. 7-IO. 1825 . 
Type locality: "In Mexico."

Distribution: Providence Mountains, southeastern California, eastward through southern Utah to western Texas, and south through northern Mexico. Lower Sonoran.

Specimens examined: Providence Mountains, Cooper.

\section{COWANIA.}

I. Cowania Stansburiana Torr. Stansb. Exped. 386. pl. 3. 1852.

Type locality: "Stansbury's Island, Salt Lake."

Distribution: Utah and Nevada southward through Arizona and New Mexico. Lower Sonoran. C. mexicana Don, of central Mexico, has a shorter, almost campanulate calyx-tube.

Specimens examined: This has been collected by Brandegee in the Providence Mountains, but I have not seen his specimens.

Cowania mexicana dubia Brandegee (Zoe 5: 149. 1903) I have not seen. Its flowers are smaller than those of C. Stansburiana and the styles are densely covered with short bristle-like hairs instead of plumose.

\section{CERCOCARPUS. Mountain mahogany.}

Leaves narrowly lanceolate; margins entire, revolute. Leaves obovate to rounded, margins toothed above.

r. C. ledifolius.

Leaves obovate, pubescent or glabrous beneath.

Calyx tomentose; its teeth broadly triangular.

Calyx glabrous; its teeth nearly subulate.

Leaves oval to rounded, densely white downy beneath.

2. C. betulaefolius.

3. C. minutiflorus.

4. C. Traskiae.

I. Cercocarpus ledifolius Nutt. in Torr. \& Gray, Fl. N. Am.1: 427. 1838 .

Type locality: "Rocky Mountains, in alpine situation on the summits of the hills of Bear River of Timanagos, near the celebrated 'Lear Springs."

Distribution: Southwestern Washington and southern Idaho south to southern California and Arizona. Most frequent in the upper part of the Transition Zone, but sometimes extends to the edges of the Upper Sonoran.

Specimens examined: Mount Pinos, Elmer 3974; Mount San Antonio, Abrams I9ro, 2680; Mill Creek Falls, altitude 1800 meters, Parish 5066; North Baldy, San Gabriel Mountains, 
Abrams \& McGregor 6I6; Lone Pine Canyon, San Gabriel Mountains, Abrams छ McGregor 663.

2. Cercocarpus betulaefolius Nutt.; Hook. Ic. Pl. $4:$ pl. 322. I84I.

Cercocarpus betuloides Nutt.; Torr. \& Gray, Fl. N. Am. 1: 427. 1840.

Cercocarpus parvifolius glaber S. Wats. Bot. Calif. 1: $175 . \quad 1876$. Cercocarpus parvifolius betuloides Sarg. Silva N. Am. 4: 66. 1892 . Distribution: Coast Ranges of central California southward to the mountains of northern Lower California. Upper Sonoran.

Specimens examined: Santa Barbara, Nuttall; Brandegee, June, 1889; Elmer 3868; Mountain Drive, near Santa Barbara, Abrams 4I2I; Sepulveda Canyon, Santa Monica Mountains, Abrams 3II 6 ; Fort Tejon, Abrams \& McGregor 293; Topatopa Mountains, Abrams \& McGregor 108; Oakgrove Canyon, Abrams \& McGregor 325: Mount Wilson trail, Abrams 1522; near Monrovia, Dudley, Nov. 18, 1907; Rock Creek, San Gabriel Mountains, Abrams छ̋ McGregor 588; Lone Pine Canyon, San Gabriel Mountains, Abrams E McGregor 674; Cleghorn Canyon, San Bernardino Mountains, Abrams \& McGregor 707; Mill Creek Canyon, Abrams E McGregor 820; Santa Ana Mountains, near Elsinore, Abrams, July 2I, I908; near Campo, Abrams 36Ir; Jacumba Hot Spring, Mearns 3356.

3. Cercocarpus minutiflorus Abrams, Bull. Torr. Bot. Club 37: 149. I910.

Cercocarpus parvifolins glaber S. Wats. Bot. Calif. 1: 175. 1876, excluding Nuttall's specimen, which is the type.

Cercocarpus betulaefolius minor Schneider, Handb. Laubholzk. 1: 531. 1905 (?).

Type locality: "On chaparral covered hills near San Dieguito on road to San Diego."

Distribution: On chaparral covered hills and mesas from the vicinity of Escondido, San Diego County, southward and westward to northern Lower California. Upper and Lower Sonoran.

Specimens examined: San Dieguito (Bernardo), Abrams 3376.

4. Cercocarpus Traskiae Eastwood, Proc. Calif. Acad. III. 1: 136. 1898 .

Type locality: "At the northern part of the island [Santa Catalina] in a volcanic region known as 'Salte Verde." " 
Distribution: This peculiar species has been found only at the type "locality. It is included here on account of its botanical interest.

\section{ADENOSTOMA. Chamise.}

Leaves" fascicled, channelled on one side.

Leaves linear-subulate, acute, 6-9 mm. long.

Leaves"obtuse, 4-6 $\mathrm{mm}$. long.

I. A. fasciculatum.

2. A. fasciculatum obtusifolium. Leaves not fascicled, narrowly linear, 6-10 $\mathrm{mm}$. long.

3. A. sparsifolium.

I. Adenostoma fasciculatum Hook. \& Arn. Bot. Beech. I39, pl. 30.1832 .

Type locality: "In sandy plains in the Bay of Monterey."

Distribution: The chamise is one of the most characteristic shrubs of the California chaparral, being confined to the California Sub-area of the Upper Sonoran. In southern California it is much more abundant on foothills bordering the interior valleys, than on the coastal mountains. Over large tracts on the eastern end of the San Gabriel Mountains and on the lower southern slopes of the San Bernardino Mountains it often forms almost pure thickets.

Specimens examined: Montecito, Franceschi, r894; Red Reef Canyon, Topatopa Mountains, Abrams \& McGregor 140; Mount Wilson, Grinnell, June 6, I903; Little Santa Anita Canyon, Abrams 2649; Santa Monica Mountains, Abrams 1263; vicinity of San Bernardino, Parish 4838; Lone Pine Canyon, San Gabriel Mountains, Abrams E McGregor 665; near Potrero, Abrams 3727 .

ia. Adenostoma fasciculatum obtusifolium S. Wats. Bot. Calif. 1: $184 . \quad 1876$.

Adenostoma fasciculatum var. $\beta$ Torr. \& Gray, Fl. N. Am. 1: 430. I840.

Adenostoma brevifolium Nutt.; Torr. \& Gray, Fl. N. Am. 1: 430. I840, as a synonym.

Type locality: "San Diego."

Distribution: Chiefly confined to the vicinity of San Diego, and extending from there southward into Lower California, but what seems to be identical occurs on the desert slopes of the Liebre Mountains. Upper and Lower Sonoran. 
Specimens examined: "Upper California," Nuttall; San Diego, Emory, 1846; Thurber 564; Palmer 79; Oakgrove Canyon, Liebre Mountains, Abrams \&ै McGregor 387.

2. Adenostoma sparsifolium Torr. in Emory's Notes Mil. Reconnois. I40. 1848.

Type locality: "Cordilleras of California." Vicinity of Warner's ranch, San Diego County, where it was collected by Emory, Dec. 2, 1846 .

Distribution: San Jacinto Mountains southward to Lower California. Upper Sonoran.

Specimens examined: Vicinity of Warner's ranch, Emory, Dec. 2, I846; mountains east of San Diego, Parry, July, 1850; near Pine Valley, Orcutt, August 31, 1883; Mearns 3982; exposed south slopes in the vicinity of Chalk Hill, altitude 1440 meters, San Jacinto Mountains, Hall 2638; San Felipe, altitude 900 meters, Susan G. Stokes, July 25, 1895.

\section{COLEOGYNE.}

I. Coleogyne ramosissima Torr. Pl. Frem. 8 , pl. 4. 1853.

Type locality: "Sources of the Mohave and Virgin Rivers, tributaries of the Colorado of the West, in the mountains of southern California."

Distribution: Almost throughout the Mohave Desert, eastward to southern Nevada and Arizona. Higher altitudes of the Lower Sonoran, and extending into the Upper Sonoran.

Specimens examined: Ironwood Spring, Colorado Desert, Brandegee, April 7, 190r.

\section{Iо. KUNZIA.}

I. Kunzia glandulosa (Curran) Greene, Pittonia 2: 299. 1892. Purshia glandulosa Curran, Bull. Calif. Acad. 1: 153 . I885.

Type locality: "On the Mohave side of Tehachapi Pass."

Distribution: Desert slopes of the mountains bordering the Mojave Desert. Upper Sonoran.

Specimens examined: Rock Creek, Davidson, Aug., 1901; Abrams \&8 McGregor 528; Gold Mountain, San Bernardino Mountains, altitude 2300 meters, Abrams 2069; southeastern slope of Mount Pinos, Abrams E McGregor 259; between Tehachapi and 
Willow Springs, Abrams Eं McGregor 426; Lone Pine Canyon, San Gabriel Mountains, Abrams $\Xi$ McGregor 662.

\section{CHAMAEBATIA.}

I. Chamaebatia australis (Brandegee) Abrams, Bull. Torr. Bot. Club 34: 623. I907.

Chamaebatia foliolosa australis Brandegee, Bot. Gaz. 27: 447. I899.

Type locality: "La Gruella, Lower California," and "Mt. Miguel near San Diego."

Distribution: Mount Miguel, southern San Diego County, southward through the foothills of northern Lower California. Upper Sonoran.

Specimens examined: San Miguel Mountain, Chandler 5214.

\section{ROSA. Rose.}

Foliage more or less glandular-pubescent or puberulent.

Infrastipular spines present, these and the prickles recurved or reflexed.

Leaflets canescent beneath with a close short-villous pubescence. 1. R. Aldersoni.

Leaflets scarcely paler beneath, somewhat glandular-pubescent.

2. R. californica.

Infrastipular spines wanting; prickles often numerous, slender and straight.

Foliage glabrous; infrastipular spines wanting; prickles straight.

3. R. gratissima.

4. R. mohavensis.

I. Rosa Aldersoni Greene, Pittonia 5: iro. I903.

Type locality: "Witch Creek, San Diego Co., California."

Distribution: This species is closely related to $R$. californica and may be merely a canescent form of it, but it seems to occupy a more or less distinct geographic area. The plants I have referred to this species grow in the higher parts of the chaparral and in the Transition Zone of the San Bernardino and the Cuiamaca Mountains.

Specimens examined: West Fork of Deep Creek, San BernardinoMountains, Abrams E McGregor 714; Strawberry Peak, San Bernardino Mountains, Abrams 2054; Witch Creek, Cuiamaca Mountains, Alderson, June, 1894; Pine Valley, Mearns 3984 . 
2. Rosa californica Cham. \& Sch. Linnaea 2: 35.1827.

Type locality: "San Francisco."

Distribution: In the Coast Ranges and the interior of central California, southward to San Diego and perhaps northern Lower California. In southern California it is the only rose in the valleys and lower foothills of the coastal slope. There is considerable variation in the shape of the leaves and in their serrations. In most of the material examined the hypanthium is globose and glabrous in the flowering stage. Specimens from Oakgrove Canyon, Liebre Mountains, however, have an obovate hypanthium, and others from Red Reef Canyon, Topatopa Mountains, are pubescent on the hypanthium and sepals. Upper Sonoran.

Specimens examined: Santa Barbara, Elmer 4195; Fort Tejon, Abrams E McGregor 202; Red Reef Canyon, Topatopa Mountains, Abrams \& McGregor 135; between Oakgrove Canyon and Elizabeth Lake, Abrams E McGregor 407; Santa Monica Canyon, Abrams 145I; Sepulveda Canyon, Santa Monica Mountains, Abrams 2539; San Gabriel, Bigelow, March, I853; vicinity of San Bernardino, Parish 4I9I; Lakeside, Abrams 3763; near San Diego, Susan G. Stokes, June 15, 1895.

3. Rosa gratissima Greene, Fl. Fran. 73. 1891.

Type locality: "Borders of wet meadows, and about springy places in the mountains of Kern Co."

Distribution: The Tehachapi Mountains southward along the desert slopes to the San Bernardino Mountains. This species is chiefly confined to the desert slopes of the Transition Zone bordering the piñon belt.

Specimens examined: Water Canyon, Tehachapi Mountains, Abrams Eं McGregor 482; Mount Pinos, Elmer 3732; Rock Creek, desert slope of the San Gabriel Mountains, altitude 1800 meters, Abrams \& McGregor 586; Swartout Canyon, San Gabriel Mountains, Abrams \& McGregor 652; Bear Valley, San Bernardino Mountains, Abrams $282 x$.

4. Rosa mohavensis Parish, Bull. S. Calif. Acad. 1: 87, pl. 7 . 1902.

Rosa californica glabrata Parish, Ery thea 6: 88. 1898.

Type locality: "On the desert side of the San Bernardino Mountains, near water, Cushenberry Springs, altitude 400 feet." 
Distribution: Mr. Parish reports this species from the desert slope of Mount San Antonio and Rock Creek. It is closely related to $R$. gratissima, of which it may prove to be merely a glabrate form. Upper Sonoran.

Specimens examined: Cushenberry Springs, Parish $498 I$.

\section{MALACEAE. Apple Family.}

Carpels 2, free and separating.

I. Heteromeles.

Carpels 5, united and coalescent with the fleshy hypanthium.

2. Amelanchier.

\section{HETEROMElES. Christmas berry or Tollon.}

1. Heteromeles salicifolia (Presl.).

Photinia salicifolia Presl. Epimel. Bot. 204. I849.

Crataegus arbutifolia Ait. Hort. Kew. 3: 202. I8I I. Not Lam. I783.

Photinia arbutifolia Lindl. Trans. Linn. Soc. 13: I03. I821.

Heteromeles arbutifolia Roem. Syn. Monog. 3: I05. I 847.

Heteromeles Fremontiana Dec. Nouv. Ann. Mus. Par. 10: I44. 1874 .

Type locality: "Habitat in California ad Monte-rey et ad portum S. Blas Mexico occidentalis."

Distribution: The tollon or christmas berry is characteristic of the California Sub-area. It extends from Mendocino County through the coast ranges and the western slope of the Sierra Nevada to northern Lower California. It also occurs on the islands off the coast of northern California, and on Cedros Island. Upper Sonoran.

Specimens examined: Santa Barbara, Elmer 3857; Elizabeth Lake, Abrams Eं McGregor 4I3; Little Santa Anita Canyon, San Gabriel Mountains, Abrams 2648; San Gabriel Canyon, Abrams Aug. 10, 1900; Lone Pine Canyon, San Gabriel Mountains, Abrams E McGregor 676; Pine Valley, San Diego County, Mearns 3975; Jamul Valley, Susan G. Stokes, June I9, I895.

\section{AMELANCHIER. SERVICE BERry.}

Sepals erect; leaves cuspidate, entire or inconspicuously serrate at apex.

I. A. pallida.

Sepals strongly reflexed; leaves not cuspidate, distinctly serrate above.

Hypanthium and sepals tomentose without.

2. A. venulosa.

Hypanthium and sepals glabrous without.

3. A. recurrata. 
I. Amelanchier pallida Greene, Fl. Fran. 53. I891.

Type locality: "Common or dry hills of the northern and northeastern parts of the State [California]."

Distribution: I have seen no authentic specimens of this species, but the specimens here referred to it answer the description. The distribution, as originally given, is therefore greatly extended. Transition.

Specimens examined: Water Canyon, Tehachapi Mountains, Abrams छ McGregor 490; Cuiamaca Lake, Cuiamaca Mountains, Abrams 3912.

2. Amelanchier venulosa Greene, Pittonia 4: 21. 1899.

Type locality: "Cushenberry Springs, in Southern California."

Distribution: Apparently confined to the piñon belt and the Transition Zone of the San Gabriel and the San Bernardino Mountains. The specimens from Dry Lake are not typical, and possibly are nearer the Sierra Nevada plant which has recently been named A. siskiyouensis.

Specimens examined: Swartout Canyon, San Gabriel Mountains, Abrams छ McGregor 633; Fawnskin Park, San Bernardino Mountains, Parish 4992; Hathaway Flat, San Bernardino Mountains, Abrams E McGregor 808; Dry Lake Canyon, San Bernardino Mountains, Abrams \&5 McGregor 783.

3. Amelanchier recurvata Abrams, Bull. Torr. Bot. Club 37: I5I. I9IO.

Type locality: "In moist places in the Topatopa Mountains, altitude 5500 feet, Abrams E० McGregor 107."

Distribution: Only known from the Topatopa Mountains, but probably occurs elsewhere in the Transition Zone in the mountains of Ventura and Santa Barbara Counties.

\section{amygdalaCeae. Peach Family.}

Ovary and fruit glabrous.

Leaves deciduous.

Flowers corymbose or umbellate.

Flowers racemose.

Leaves evergreen.

Ovary and fruit velvety-pubescent.

I. Cerasus.

2. Padus.

3. Laurocerasus.

4. Amygdalus. 


\section{r. CERASUS. Cherry.}

I. Cerasus arida Greene, Proc. Biol. Soc. Wash. 18: 57. 1905. Type locality: "Borders of the desert at eastern base of the San Bernardino Mountains."

Distribution: The cherry referred to this species occurs sparingly in the Transition Zone of the San Gabriel, San Bernardino and Cuiamaca Mountains. Considerable variation occurs in the specimens examined, and it is evident that a great deal of field study must be given to the western cherries before they are understood. The specimens from Strawberry Peak have narrow, oblanceolate, acutish leaves, which are pubescent and somewhat glandular on the lower surface. They also differ in their prominent approximate veins.

Specimens examined: Lytle Creek Canyon, altitude 1725 meters, Hall I47I; near Strawberry Peak, San Bernardino Mountains, Abrams छ McGregor 727; South Peak, Cuiamaca Mountains, Abrams 3943; Green Valley, San Bernardino Mountains, Abrams E McGregor 734; San Jacinto Mountains, Hasse 5680, 1263; San Bernardino Mountains, altitude 2180 meters, Parish 3329.

\section{PADUS. ChOKE CHERry.}

I. Padus demissa (Nutt.) Roem. Syn. Rosifl. 87. 1847.

Cerasus demissa Nutt. in Torr. \& Gray, Fl. N.Am. 1:4II. 1840. Prunus demissa Walp. Rep. 2: 10. I843.

Padus virginiana demissa Schneider, Handb. Laubholzk. 1: 642. 1906.

Type locality: "Plains of the Oregon towards the sea, and at the mouth of the Wahlamet."

Distribution: Washington and Idaho to southern California. In southern California there is considerable variation in pubescence. The Cuiamaca specimens are glabrous except for pubessence along the mid-vein, thus approaching very closely $P$. melanocarpa of the Rocky Mountains and Great Basin. Upper Sonoran and Transition.

Specimens examined: Mount San Antonio, altitude 2700 meters, Abrams 2697; Swartout Canyon, San Gabriel Mountains, Hall, June, 1899; Abrams छ McGregor 639; North Baldy, San Gabriel Mountains, Abrams Eं McGregor 620; Cuiamaca, Abrams 3828; "summit of the cordillaries east of San Diego," Parry, June, I850. 


\section{$(384)$}

\section{LAUROCERASUS. Holly-leaved cherry.}

I. Laurocerasus ilicifolia (Nutt.) Roem. Syn. Rosifl. 92. I 847 .

Cerasus ilicifolia Nutt.; Hook. \& Arn. Bot. Beach. Voy. 340. 1832.

Prunus ilicifolia Walp. Rep. 2: IO. 1843.

Type locality: "St. Barbara, California, Douglas, Nuttall."

Distribution: Coast Ranges from San Francisco Bay south to the southern borders of the State. In the northern part of its range this species often becomes a good sized tree, but in our region it is usually reduced to a shrub. The holly-leafed cherry is common throughout southern California in the foothills and mountains. Upper Sonoran.

Specimens examined: Santa Barbara, Douglas; Nuttall; Santa Ynez Mountains, Elmer 3775; Cuddy Canyon, near Tejon Pass, Abrams Eक McGregor 282; Sepulveda Canyon, Santa Monica Mountains, Abrams 2551; Mount Lowe, Grant 1046; hills near Verdugo, Abrams 1380; Reche Canyon, Hall r104; vicinity of San Bernardino; Parish, June, 1897, Potrero, Abrams 374I; mountains east of San Diego, Parry I850; Jacumba Hot Spring, Mearns 3354.

\section{AMYGDALUS. Almond.}

Leaves narrowly spatulate, entire; styles very short.

I. A. fasiculata. Leaves ovate or nearly round; denticulate; styles elongated. 2. A. Fremonti.

I. Amygdalus fasciculata (Torr.) Greene, Fl. Fran. 49. I89r. Emplectocladus fasciculatus Torr. Pl. Frem. I0, pl. 5. I850. Prunus fasciculata A. Gray, Proc. Am. Acad. 10: 70. I874.

Type locality: "Sierra Nevada of California; probably in the southern part of the range."

Distribution: Desert slopes of the San Bernardino Mountains north to the eastern slopes of the southern Sierra Nevada and eastward to southern Utah and Arizona. Canyons and rocky slopes of the juniper belt. Upper and Lower Sonoran.

Specimens examined: Rock Creek, desert slope of the San Gabriel Mountains, Abrams E McGregor 525; Lone Pine Canyon, San Gabriel Mountains, Abrams \& McGregor 668; Cushenberry Spring, Abrams 2152; summit of Providence Mountains, Cooper, May 29, r86r. 


\section{$(385)$}

2. Amygdalus Fremontii (S. Wats.).

Prunus Fremontii S. Wats. Bot. Calif. 2: 442 . 1880.

Type locality: "Coast Ranges of southern California;"Oriflamme Canyon, San Diego County (D. Cleveland); San Bernardino Mountains, Parry E Lemmon, n. 108, I876. Also collected by Fremont in 1846 , locality uncertain."

Distribution: Southern slopes of the Chuckawalla Mountains, south to northern Lower California. Lower Sonoran and extending into the lower edges of the Upper Sonoran.

Specimens examined: San Felipe, Parry, 1850 (Referred to Prunus subcordata by Torr. Bot. Mex. Bound. 63); no locality, Parry छ Lemmon 108.

MimosaCeAe. Mimosa Family.

Stamens numerous; pods flattened, straight or more or less curved.

Stamens Io.

Pods straight or slightly curved.

Pods coiled into a spiral.

I. Acacia.

2. Prosopis.

3. Strombocarpus.

\section{ACACIA. Acacia.}

I. Acacia Greggil A. Gray, Pl. Wright. 1: 65. I850.

Type locality: "Western Texas" and "dry valley west of Patos, Northern Mexico."

Distribution: A characteristic shrub of the Lower Sonoran, extending from the western borders of the Colorado Desert in southern California eastward to western Texas and southward into Lower California and northern Mexico.

Specimens examined: Banner, Susan G. Stokes, July 26, I895; San Felipe, Abrams 3970; Carriso Creek, Abrams 3985; Piute Creek, Norman C. Wilson, June 6, I893; near Indio, Hall 5987; Jacumba Hot Spring, Cleveland, July 3, I884; Providence Mountains, Brandegee, May 25, 1902.

Leaves glabrous.

Leaves pubescent.

\section{PROSOPIS. Mesquit.}

I. Prosopis glandulosa Torr. Ann. Lyc. N. Y. 2: 192.1828. Prosopis odorata Torr. \& Frem. in Frem. Second Rep. 313, pl. I. I845, excluding fruit which is Strombocarpus pubescens.

Type locality: "On the Canadian? [River]."
I. P. glandulosa.

2. P. velutina. 
Distribution: Deserts of southern California eastward to western Texas, and southward into Lower California and northern Mexico. The Prosopis juliflora of the California botanies, but not DC. Lower Sonoran.

Specimens examined: Lancaster, Elmer 3726; Cushenberry Springs, Abrams 2148; San Bernardino, Parish 2928; Abrams 2148; San Jacinto Lake, Hall IIo6; San Felipe, Susan G. Stokes, July 25, I895; San Diego, Herre, July 19, 1902.

2. Prosopis velutina Wooten, Bull. Torrey Club 25: 456. ז 898.

Type locality: Several localities were originally cited, but the plants from which the description was drawn were collected by Pringle "in Arizona on mesas and in valleys," and by Wilcox "at Fort Huachuca, Ariz."

Distribution: Southern Arizona southward into adjacent Sonora. A single arborescent shrub, apparently indigenous, was found by the writer on the sandy river bottom of the San Diego River, near Grantville, southwestern San Diego County. Lower Sonoran.

Specimens examined: Grantville, Abrams 3753.

\section{STROMBOCARPUS. ScREW-BEAN.}

I. Strombocarpus pubescens (Benth.) A. Gray; Torr. Pacif. R. Rep. 5: 360. 1858 .

Prosopis pubescens Benth. Lond. Journ. Bot. 5: 82. 1846.

Prosopis Emoryi Torr. in Emory, Notes Mil. Reconnois. I39. I848.

Prosopis odorata Torr. \& Frem. in Frem. Second Rep. 313. I845, in part.

Type locality: This species is said to have been collected in "California between San Miguel and Monterey," but the species has not since been found in that part of the State. Coulter, the collector, travelled southward from Monterey to Yuma, and it is probable that he obtained his specimens somewhere in the Colorado Desert along the old San Felipe and Yuma trail.

Distribution: From the interior and eastern parts of the Mohave Desert southward into Lower California and Sonora. Lower Sonoran.

Specimens examined: Near San Bernardino, Parish, July 8, 
I898; Abrams 2954; Imperial Valley, near Calexico, Abrams 3999.

CAESAlPiniaceaE. Senna Family.

Leaves simple, rounded; flowers resembling the papilionaceous, purple.

Leaves I-2-pinnate; flowers regular, yellow.

I. Cercis.

Pods not compressed, torose, gland on upper petal wanting.

2. Parkinsonia.

Pod compressed, only slightly contracted between the seeds; gland on upper petal prominent.

3. Cercidium.

\section{CERCIS. RED-BUD.}

I. Cercis occidentalis Torr.; A. Gray, Bost. Journ. Nat. Hist. 6: $177 . \quad 1850$.

Cercis californica Torr.; Benth. Pl. Hartw. 36r. 1857. Siliquastrum occidentale Greene, Man. Bay Region, 84. I894.

Type locality: "Rocky plains of the Upper Guadaloupe."

Distribution: Lower edges of the Arid Transition from Sacramento Canyon and Mendocino County southward to the Cuiamaca Mountains, also in New Mexico and western Texas.

Specimens examined: Cuiamaca Mountains, between Cuiamaca and Oriflamme Mines, Abrams 3924.

\section{PARKINSONIA.}

Rachis flattened, much-elongated; leaflets scattered. Rachis terete; leaflets in distinct pairs.

1. P. aculeata.

2. P. microphylla.

\section{Parkinsonia aculeata L. Sp. Pl. 375. I753.}

Type locality: "Habitat in America calidiore."

Distribution: Valley of the Colorado River, northern Mexico and the lower Rio Grande; naturalized in the West Indies and the tropics of both hemispheres. Lower Sonoran and Tropical.

Specimens examined: I have not seen any specimens from southern California.

2. Parkinsonia microphylla Torr. Pacif. R. Rep. 4: 82. 1857. Type locality: "Banks of the Colorado [where it was collected by Mr. Schott near Fort Yuma] and on Williams River."

Distribution: Deserts of southern Arizona west to the Colorado Desert of southern California, and southward to adjacent Sonora and Lower California. Lower Sonoran. 
Specimens examined: Diluvial banks of the Colorado, Ft. Yuma, Schott, Jan. I3, I854.

\section{Cercidium. Palo verde.}

I. Cercidium Torreyana (S. Wats.) Sargent, Gard. \& For. 2: 388. 1889.

Parkinsonia Torreyana S. Wats. Proc. Am. Acad. 11: I35. 1876. Type locality: "On the Lower Colorado River and in the valleys of western and southern Arizona."

Distribution: Colorado Desert and western Arizona southward into Sonora and Lower California. Lower Sonoran.

Specimens examined: The Needles, Jones 3864; Palm Springs, Parish 4II5; Mecca, Miss M. McKibben; Coyote Canyon, Hall 2790; Salton, Davey 8043.

\section{KRAMERIACEAE. Krameria Family.}

\section{KRAMERIA.}

Prickles of the fruit barbed their whole length.

Prickles of the fruit barbed only at apex.
I. K. parvifolia.

2. K. Grayi.

I. Krameria parvifolia Benth. Bot. Voy Sulph. 6, pl. 2. I 844 .

Type locality: "Bay of Magdalena," Lower California.

Distribution: Tia Juana southward into Lower California, and eastward to southern New Mexico and adjacent Sonora. Lower Sonoran.

Specimens examined: Rabbit Springs, Mohave Desert, Parish 2334; eastern base of San Jacinto Mountains, Hall 2II4; San Felipe, Thurber 632; Jacumba Hot Spring, Abrams 3662; Cleveland's specimens from the vicinity of San Diego, which are cited in the "Botany of California," I have not seen.

2. Krameria Grayi Rose \& Painter, Contr. Nat. Herb. 10: 108. 1906.

Krameria canescens A. Gray, Pl. Wright. 1: 42. I852. Not Willd. 1825 .

Type locality: "Prairies near the Pecos."

Distribution: Western borders of the Colorado Desert, southern California, eastward to New Mexico, and southward into adjacent Lower California and Sonora. Lower Sonoran. 
Specimens examined: Morongo Canyon, Parish 2979; Signal Mountain, Abrams 3170, and Dec. 29, 1907; San Felipe, Parry, 1850.

\section{FABACEAE. Pea Family.}

Leaves palmately foliate.

Flowers solitary.

Flowers racemose.

Leaves unequally or equally pinnate or rarely entire.

Flowers umbellate or solitary.

Flowers in spikes or racemes, not umbellate.

I. Xylothermia.

2. Lupinus.

Herbage glandular-dotted.

Flowers racemose; wings and keel wantıng. 4. Amorpha.

Flowers spicate or racemose; petals all present. 5. Parosela.

Herbage not glandular-dotted.

3. Syrmatium.

I. XYLOTHERMIA. Stingaree-bush.

Twigs and leaves green and merely puberulent.

Twigs and leaves canescent.
I. X. montana.

Ia. X. montana tomentosa.

I. Xylothermia montana (Nutt.) Greene, Pittonia 2: i88. I 89 I.

Pickeringia montana Nutt. in Torr. \& Gray, Fl. N. Am. 1: 389. 1840.

Type locality: "Summits of the mountains in the vicinity of St. Barbara, California."

Distribution: Islands off the coast of southern California, and on the mainland in the chaparral of the Coast Ranges from the vicinity of Santa Barbara, northward to Sonoma County, and in the Sierra Nevada at least as far north as Mariposa County. Upper Sonoran.

Specimens examined: Santa Cruz Island, Brandegee; La Cumbre Peak, Santa Ynez Mountains, Abrams 4320.

Ia. Xylothermia montana tomentosa Abrams, Bull. Torrey Club 34: 263. 1907.

Type locality: "Near E1 Nido, San Diego County."

Distribution: In the chaparral from the San Bernardino Mountains southward to near the National Boundary, and probably extending along the western slopes of the mountains of northern Lower California. Upper Sonoran. 
Specimens examined: San Bernardino Mountains, altitude $165^{\circ}$ meters, Parish 4990; El Nido, Abrams 3530.

\section{LUPINUS. LUPINE.}

Keel ciliate on the inner margin above the middle.

Flowers yellow or sometimes purple; seeds dark brown, not mottled; leaves green, sparsely pubescent.

I. L. arboreus.

Flowers purple; seeds mottled; leaves more or less canescent.

Lower calyx-lobe entire; leaflets oblanceolate, acutish, $3-5 \mathrm{~cm}$. long.

Seeds $5 \mathrm{~mm}$. long, dark gray, mottled with dark brown; pubescence of the branches and petioles short-villous, spreading.

2. L. longifolius.

Seeds scarcely $4 \mathrm{~mm}$. long, light tan, mottled with dark tan; pubescence of the branches and petioles appressed-silky.

Lower calyx-lobe 3-toothed; pubescence appressed-silky.

3. L. Brittoni.

Leaflets spatulate, rounded or very obtuse at apex, longest 2.5 $\mathrm{cm}$. long ; bractlets $5-6 \mathrm{~mm}$. long.

4. L. Hallii.

Leaflets narrowly oblanceolate, obtuse or acutish, mostly 3-4 $\mathrm{cm}$. long; bractlets $10-12 \mathrm{~mm}$. long.

Keel glabrous; herbage densely silky-pubescent.

5. L. Douglasii.

6. L. Chamissonis.

1. Lupinus arboreus Sims, Bot. Mag. 18: pl. 682. I803.

Type locality: "Its native country is unknown to us." Probably collected at San Francisco or Monterey.

Distribution: Vicinity of the coast from San Francisco south to Santa Barbara. Upper Sonoran.

Specimens examined: Vicinity of Santa Barbara, Elmer 3843.

2. Lupinus longifolius (S. Wats.) Abrams, Fl. Los Angeles, 209. 1904.

Lupinus Chamissonis longifolius S. Wats. Bot. Calif. 1: I17. 1876. Type locality: "From San Diego (Cleveland) to Ojai (Peckham), San Pascual (Thurber) and San Antonio River, Brewer."

Distribution: Slopes of the lower hills in the coastal region of southern California. Upper Sonoran.

Specimens examined: Los Angeles, Lyon, April, 1884; Little Santa Anita Canyon, Abrams 262I; Playa del Rey, Abrams 2505; Santa Monica Forestry Station, Barber 44; Santa Monica Mountains, Abrams 1696; San Pasqual, Thurber 615; San Diego, Cleveland 720; hillsides near Ysidora, Abrams 3299. 


\section{Lupinus Brittoni sp. nov.}

Bushy and shrubby below, with long herbaceous branches, about I $\mathrm{m}$. high; herbage appearing glaucescent with a minute appressed pubescence; petioles slender, exceeding the leaflets; leaflets 6-8, oblanceolate, 25-45 $\mathrm{mm}$. long, acutish at apex, with a prominent recurved point; racemes $15-30 \mathrm{~cm}$. long; manyflowered; flowers scattered or in approximate whorls; pedicels $5 \mathrm{~mm}$. long; lower calyx-lobe entire, $7 \mathrm{~mm}$. long; corolla (in dried specimens) I5 $\mathrm{mm}$. long, violet-purple; keel ciliate toward the middle on the upper edges; pod $3 \mathrm{~cm}$. long; seeds $5-6$, scarcely $4 \mathrm{~mm}$. long, nearly as wide, light tan, specked with dark tan.

Type collected by the writer (3904) in Cottonwood Valley, San Diego County, June 5, 1903, and deposited in the Herbarium of Stanford University.

The glaucescent instead of silvery herbage, the shorter and closely appressed pubescence of the pedicels and calyx, and the minute pale seeds, separate this species readily from true $L$. albifrons of central California. The characters given in the key contrast it with the other southern California members of this group.

4. Lupinus Hallin Abrams, Bull. Torr. Bot. Club 37: I5I. 1910.

Type locality: "Reche Canyon, altitude 400 meters, San Bernardino Mountains."

Distribution: Foothills of the San Gabriel and the San Bernardino Mountains. Upper Sonoran.

Specimens examined: Reche Canyon, altitude 400 meters, Hall, May I 5, rgor; vicinity of San Bernardino, Parish 4772; Anaheim, Baker 4102 .

5. Lupinus Douglasil Agardh, Syn. Gen. Lupin. 34. 1835.

Type locality: Collected by Douglas, probably near Monterey.

Distribution: Dry hillsides near Monterey southward to the Santa Ynez Mountains. Upper Sonoran.

Specimens examined: Fremont's Pass, Santa Ynez Mountains, Mrs. Marshall, July, I907.

6. Lupinus Chamissonis Esch. Mem. Acad. Petersb. 10: 288. I 826.

Type locality: "in Novae Californiae arenosis." This was probably collected at San Francisco. 
Distribution: Along the seashore from San Francisco south to Orange County. Upper Sonoran.

Specimens examined: Playa del Rey, Abrams 2502; Santa Monica, Hasse 4823; Redondo, Grant 724.

\section{SyRMATIUM. California broom.}

Herbage nearly glabrous, not silky-pubescent.

Calyx-teeth subulate, about $2 \mathrm{~mm}$. long.

Calyx-teeth very short and triangular.

Herbage appressed silky-pubescent.

1. S. glabrum.

2. S. junceum.

3. S. procumbens.

I. Syrmatium glabrum Vogel, Linnaea 10: 59i. 1836.

Hosackia scoparia Nutt.; Torr. \& Gray, Fl. N. Am. 1: 325. 1838.

Hosackia glabra Torr. U. S. Expl. Exped. 17: 274. 1874.

Lotus glaber Greene, Pittonia 2: I48. 1890.

Type locality: "California." Probably collected in the vicinity of the old Russian settlement, near Bodega Bay.

Distribution: Common on dry hillsides and slopes, especially in chaparral, throughout the California Sub-area of the Upper Sonoran, from Mendocino County and the western slopes of the Sierra Nevada southward to northern Lower California.

The species of this genus here included are low broom-like suffrutescent plants, and not true shrubs.

Specimens examined: Santa Barbara, Elmer 388I; Torrey I05; Sulphur Mountain, near Santa Paula, Abrams \& McGregor 32; Oakgrove Canyon, Liebre Mountains, Abrams \& McGregor 390; Los Angeles, Tracy छఠ Evans, July 5, I887; foothills, near San Bernardino, Parish 4776, S. B. छ W.F. Parish 146; San Diego, Nuttall; Thurber 524; Orcutt, Feb. 15, 1886; Palmer 58; Jacumba Hot Spring, Abrams 3652 .

2. Syrmatium junceum (Benth.) Greene, Bull. Calif. Acad. 2: I47. 1886.

Hosackia juncea Benth. Trans. Linn. Soc. 17: 326. 1837. Lotus junceus Greene, Pittonia 2: I48. 1890.

Type locality: "California." Collected by Douglas, probably in the vicinity of Monterey.

Distribution: A maritime species occurring along the coast from Monterey to San Diego. It is closely related to S. glabrum, and 
possibly is only a form of that widely distributed and variable species. Upper Sonoran.

Specimens examined: Santa Barbara, Nuttall; Playa del Rey, Abrams 2518; Del Mar, Brandegee, June 4, Susan G. Stokes, June 4, I895; Tia Juana, Abrams 3460.

3. Syrmatium procumbens Greene, Bull. Calif. Acad. 2: i48. I 886.

Hosackia procumbens Greene, Bull. Calif. Acad. 1: 82. 1885.

Lotus procumbens Greene, Pittonia 2: 149. 1890.

Type locality: "Tehachapi, Kern County."

Distribution: This species is confined chiefly to the piñon belt of the mountains surrounding the western end of the Mohave Desert. The original specimens from Tehachapi were described as prostrate, but in the Liebre Mountains the plants are erect. The species is undoubtedly closely related to $S$. sericeum, and probably will prove identical when that species becomes better known. Upper Sonoran.

Specimens examined: Tehachapi, Brandegee, May, r889; Mount Pinos, Elmer 3988; near Lancaster, Davidson, May I0, I893; Oakgrove Canyon, Liebre Mountains, Abrams Eे McGregor 337; Swartout Canyon, San Gabriel Mountains, Hall I254; Burcham's ranch, Mohave River Canyon, Parish 4858; Tejon Pass, Hall 6264.

\section{AMORPHA. FAlse indigo.}

Twigs and leaf-rachis with prickle-like glands; calyx-teeth triangular-lanceolate, over half the length of the tube.

I. A. californica.

Twigs and leaf-rachis without prickle-like glands; calyx-teeth short-triangular.

2. A. occidentalis.

I. Amorpha californica Nutt. in Torr. \& Gray, Fl. N. Am. 1: 306. I 838 .

Type locality: "Santa Barbara; near the coast."

Distribution: In the chaparral of the coast slope of the southern California mountains, from the vicinity of Santa Barbara southward to San Pedro Martir Mountain. Upper Sonoran.

Specimens examined: Santa Barbara, Nuttall; Mount Pinos, Elmer 3950; Red Reef Canyon, Topatopa Mountains, Abrams है McGregor I30; Mount Wilson, Grant 39; Little Santa Anita Canyon, San Gabriel Mountains, Abrams 2622; San Bernardino 
Mountains, Hall 1288 ; Deep Creek, Abrams छ McGregor 73I; Hathaway Flat, San Bernardino Mountains, Abrams छ McGregor 806; Santa Ana Mountains, Abrams 1828.

\section{Amorpha occidentalis sp. nov.}

Shrubby below, 2-3 meters high; flowering branchlets minutely pubescent; leaf-rachis sparsely pubescent, without pickle-like glands, bearing 8-10 pairs of leaflets; leaflets ovate to narrowly oblong, sparsely pubescent with short-appressed hairs, firm in texture, 2-4 cm. long; raceme $10-18 \mathrm{~cm}$. long; pedicels $1.5 \mathrm{~mm}$. long; calyx-tube nearly glabrous, scarcely $2 \mathrm{~mm}$. long; calyx-teeth very short, triangular, densely short-villous; petal about $5 \mathrm{~mm}$. long; mature fruit not seen.

This species has been understood as $A$. californica Nutt., but Nuttall's specimens in the Torrey Herbarium, although too young to determine accurately the character of the calyx-teeth, have prickle-like glands. Plants from Santa Barbara, the type locality, agreeing with Nuttall's as to prickle-like glands, have lanceolate calyx-teeth nearly equaling the tube. I have not seen the type of $A$. hispidula Greene, but the central California plants are less pubescent, and have relatively shorter calyx-teeth.

Type: San Diego River, near the Old San Diego Mission, Abrams 3425, May 6, 1903. Type specimen deposited in the Stanford University Herbarium.

Distribution: Foothills of the San Bernardino Mountains southward to San Diego, and probably adjacent Lower California. Upper and Lower Sonoran.

Specimens examined: Foothills, San Bernardino Mountains, Parish, June, 1900; Reche Canyon, San Jacinto Mountains, Hall, May 15, 1900; eastern base of the San Jacinto Mountains, Hall 212I; Janal, altitude 300 meters, Susan G. Stokes, June 19, I895; San Diego, Palmer 65; Jacumba Hot Spring, Cleveland, July 3, 1884; Julian, Dunn, Aug. I892.

\section{Leaves pinnate.}

\section{Parosela. Dalea.}

Calyx hoary-tomentose, its lobes slender, equaling or exceeding the tube.

Calyx 4-5 mm. long; spikes short, head-like.

I. P. Emoryi.

Calyx 8-10 mm. long; spikes loose, 3-4 cm. long. 2. P arborescens.

Calyx appressed silky-pubescent to nearly glabrous, its lobes broad, usually shorter than the tube.

Glands not prickle-like; branchlets appressed-pubescent. 


\section{(395)}

Calyx densely appressed silky-pubescent.

Calyx sparsely appressed-pubescent.

Leaves simple.
3. P. californica.

4. P. Fremontii.

5. P. Saundersii.

Herbage green and nearly glabrous; leaves narrowly linear.

6. P. Schottii.

Herbage hoary with a minute appressed pubescence. 7. P. spinosa.

r. Parosela Emoryi (A. Gray) Heller, Cat. N. Am. Pl. ed. 2, 6. 1900.

Dalea Emoryi A. Gray, Mem. Am. Acad. II. 5: 315. 1855.

Type locality: "On the desert table-lands of the Gila."

Distribution: Western borders of the Colorado Desert, eastward to southern Arizona, and southward into Lower California and Sonora. Lower Sonoran.

Specimens examined: Palm Springs, Parish 4II2; Carriso Creek, Abrams 3987; Signal Mountain, Abrams 3180, and Dec. 29, 1907.

2. Parosela arborescens (Torr.) Heller, Cat. N. Am. Pl. ed. $2,5$. Igoo.

Dalea arborescens Torr.; A. Gray, Mem. Am. Acad. II. 5: 316. I 855 .

Type locality: "Mountains of San Fernando, a southern branch of the Sierra Nevada, California."

Distribution: Apparently confined to the arid mountains and hills of the Mohave Desert. Lower Sonoran.

Specimens examined: Barstow Hills, Mohave Desert, Hall 6160; Black's ranch, 32 kilometers northwest of Barstow, Hall छ Chandler 6851 .

3. Parosela californica (S. Wats.) Vail, Bull. Torrey Club 24: 17. I897.

Dalea californica S. Wats. Proc. Am. Acad. 11: І $32 . \quad$ I 876.

Type locality: "Collected by Dr. Parry in the San Bernardino Mountains, California." According to the "Botany of California" Parry's specimens were collected "in dry washes in the San Bernardino Mountains, near Cajon Pass."

Distribution: Desert slopes of the San Bernardino and San Jacinto Mountains, eastward to southern Utah. Lower Sonoran. 
Specimens examined: Canyon of the San Jacinto River, altitude 660 meters, Hall 2008; Banning, Davidson, June, 1892; Warren's Well, altitude II60 meters, Parish 2992; Pipe Canyon, Parish 299I; no locality, Parry छ Lemmon 86; Banning, Davidson, June, 1892.

4. Parosela Fremontil (Torr.) Vail, Bull. Torrey Club 24: I6. 1897 .

Dalea Fremontii Torr.; A. Gray, Mem. Am. Acad. II. 5: 316. 1855.

Type locality: "Mountains of the Pah-Utah country, S. W. California." This was collected by Fremont May 5, I 844, and according to Fremont's itinerary he was on what is now known as Muddy River a few miles above its junction with Virgin River, southern Nevada.

Distribution: Southern Utah and Nevada westward to the Providence Mountains. Lower Sonoran.

Specimens examined: Providence Mountains, Brandegee, May $24,1902$.

\section{Parosela Saundersii (Parish).}

Dalea Saundersii Parish, Bull. S. Calif. Acad. 2: 83. I903.

Type locality: "In desert sands, near Victorville, cir. $3000 \mathrm{ft}$. alt., in the Mohave Desert."

Distribution: Mohave Desert, southern California. Lower Sonoran.

Specimens examined: Near Victorville, Hall 6197; near Kane Springs, Ord Mountains, Hall छ Chandler 6826 (?).

6. Parosela Schottin (Torr.) Heller, Cat. N. Am. P1. ed. 2, 6. I900.

Dalea Schottii Torr. Bot. Mex. Bound. 53. 1859.

Type locality: "Diluvial banks of the Colorado."

Distribution: Western borders of the Colorado Desert, eastward to southwestern Arizona. Lower Sonoran.

Specimens examined: Palm Springs, Parish 4II3; Hall 5758; diluvial banks of the Colorado, Schott, Feb. I855; Chuckawalla Mountains, Hall 5973; Borregos Springs, Brandegee, April 29, I894. 
7. Parosela spinosa (A. Gray) Heller, Cat. N. Am.

Pl. ed. 2, 7. 1900.

Dalea spinosa A. Gray, Mem. Am. Acad. II. 5: 315. 1855. Asagraea spinosa Baillon, Adansonia 9: $233 . \quad 1870$.

Type locality: "Arroyos on the Gila; and on the California desert west of the Colorado."

Distribution: Western borders of the Colorado Desert, and extending eastward to southern Arizona, and southward into Lower California. Lower Sonoran.

Specimens examined: Palm Springs, Hall 5758; Carriso Creek, Abrams 3980 .

\section{OLNEYA. IRONWOOD.}

I. Olneya Tesota A. Gray, Mem. Am. Acad. II. 5: $328 . \quad$ i 855.

Type locality: "On the table-lands of the Gila," and "near Bill Williams' Fork," Arizona.

Distribution: The Colorado Desert of southern California, eastward into Arizona, and southward into Lower California and Sonora. Lower Sonoran.

Specimens examined: Signal Mountain, Abrams, Dec. 29, 1907.

\section{ZygOPhyllaceae. Caltrop Family.}

\section{COVIllea. Creosote-bush.}

I. Covillea tridentata (Moc. \& Sesse) Vail, Bull. Torr.

Bot. Club 26: 302. I899.

Zygophyllum tridentatum Moc. \& Sesse; DC. Prod. 1: 706. I824.

Zygophyllum californicum Torr. \& Frem. in Frem. Second Rep. 257. 1845 .

Type locality: "In regno Mexicano."

Distribution: The most common and widely distributed shrub of the desert districts of southern California, extending eastward to western Texas, and southward through the arid regions of Mexico and Lower California. Lower Sonoran.

Specimens examined: Willow Springs, Abrams 60 McGregor 424; Lancaster, Elmer 3664; Cushenberry Springs, Abrams 2147; Imperial Junction (Old Beach), Abrams 3202; Jacumba Hot Spring, Abrams 3675 . 


\section{$(398)$}

RUTACEAE. Rue Family.

Leaves alternate; fruit a 2-lobed coriaceous capsule.

I. Thamnosma.

Leaves opposite; fruit a drupe.

2. Cneoridium.

\section{THAMNOSMA.}

I. Thamnosma montanum Torr. \& Frem. in Frem. Second Rep. 313. 1845 .

Type locality: "Passes of the mountains, and on the Virgin river in Northern California."

Distribution: Western borders of the Colorado Desert, extending southward into northern Lower California, and eastward to Arizona and southern Utah.

Specimens examined: Mission Creek bench, eastern base of the San Bernardino Mountains, Parish 2987; Jacumba Hot Spring, Abrams 3651 .

\section{CNEORIDIUM.}

I. Cheoridium dumosum (Nutt.) Hook. f.; Brew. \& Wats. Bot. Calif. 1: 97 . I876.

Pitavia dumosa Nutt.; Torr. \& Gray, F1. N. Am. 1: 215. 1838. Type locality: "St. Diego, California."

Distribution: One of the principal components of the chaparral in the vicinity of San Diego, extending south into northern Lower California, and eastward on the desert slopes of the Cuiamaca and the San Jacinto Mountains; also in Arizona. Lower Sonoran.

Specimens examined: Near San Dieguito (Bernardo), Abrams 3378; Valley Center, Mc Clatchie, March, I893.

\section{POLYGALACEAE.}

I. POLYGALA.

I. Polygala cornuta Kell. Proc. Calif. Acad. 1: 62. 1855. Polygala californica Nutt. Torr. \& Gray, Fl. N. Am. 1: 67 I. I840, as a synonym.

Polygala Fishiae Parry, Proc. Davenp. Acad. 4: 39. 1884.

Type locality: Placerville.

Distribution: Sierra Nevada and the mountains of Santa Barbara County, southward to Lower California. A slender, sparsely branched, shrubby plant often growing a meter or more high. Upper Sonoran. 
Specimens examined: Near Santa Barbara, Torrey 74; San Gabriel Mountains near Pasadena, altitude I 200 meters, Mc Clatchie, July, I893; Sierra Madre and Mount Wilson trail, altitude I 200 meters, Abrams, July, 1906; Canyon back of Monrovia, Dudley, Dec. 1907.

\section{Euphorbiaceae. Spurge Family.}

Flowers not in involucres; perianth evident, of several segments.

Flowers dioecious; herbage densely stellate-pubescent. 1. Bernardia.

Flowers monoecious; herbage not stellate-pubescent.

Staminate flowers uppermost; herbage pubescent with simple hairs; leaves ovate, crenate-serrate.

2. Acalypha.

Pistillate flowers uppermost; leaves large, palmately lobed; glabrous. 3. Ricinus.

Flowers in involucres; perianth represented by a minute scale at the base of a filament-like pedicel.

4. Tricherostigma.

\section{BERNARDIA.}

I. Bernardia myricaefolia. (Scheele) S. Wats. Bot. Calif. 2: 70. 1880.

Tyria myricaefolia Scheele, Linnaea 25: 58I. 1852. Ricinella myricaefolia Muell. Arg. Linnaea 34: I53. I865.

Type locality: "An Waldrändern auf felsigem Boden, nördlich von Neubraunfels, am Rande der Hochebene."

Distribution: Mohave and Colorado Deserts, eastward to western Texas and northern Mexico. Lower Sonoran.

Specimens examined: San Felipe, Parry, I850.

\section{ACALYPHA.}

I. Acalypha californica Benth. Bot. Sulph. 51. 1844.

Type locality: "Bay of Magdelena," Lower California.

Distribution: Southwestern San Diego County southward at least to Magdalena Bay. Lower Sonoran.

Specimens examined: Poway, Parish 4430; near San Dieguito, Abrams 3388; between Jamul and Jamacha, Abrams 3744.

\section{RicinUs. Castor bean.}

I. Ricinus communis L. Sp. Pl. 1007. 1753.

Type locality: "Habitat in India utraque, Africa, Europa australi." 
Distribution: The castor bean has become fairly well naturalized in many parts of southern California, and often develops into small trees, 4-5 meters high.

\section{TRICHEROSTIGMA.}

I. Tricherostigma miserum (Benth.) Kl. \& Garcke, Monatsb. Akad. Berl. 248. 1859 .

Euphorbia misera Benth. Bot. Sulph. 5 I. I844.

Type locality: "San Diego," California, and "San Quentin," Lower California.

Distribution: On bluffs near the sea at San Diego, southward through western Lower California, and also on the islands off the coast of southern California. Lower Sonoran.

Specimens examined: Santa Catalina Island, Blanche Trask, Dec. 1900; San Diego, Parry, I850; Palmer 452; Pringle, May, 1882; Jones, 1882; Point Loma, Abrams 3458.

\section{BUXACEAE. Box Family.}

\section{SIMMONDSIA.}

I. Simmondsia californica Nutt. Lond. Journ. Bot. 3: 401, pl. I6. I844.

Type locality: "Covering the sides of barren hills, in argillaceous soils, near the sea, in the vicinity of St. Diego in Upper California."

Distribution: Vicinity of San Diego, southward through northern Lower California, and eastward to Arizona. Lower Sonoran.

Specimens examined: Oneonta, Herre, Aug., 1902; Mission Hills, San Diego, Abrams 3424; San Diego, Palmer 356; Parry, 1850.

\section{ANACARDiaCEAE. Sumac Family.}

Leaves compound, deciduous.

Fruit glabrous; nut globose, striate.

Fruit viscid-pubescent and often villous; nut flattened, smooth.

Leaves simple, evergreen; nut smooth.

2. Schmaltzia.

Flowers in dense racemes; fruit pubescent; pericarp viscid, acid.

3. Neostyphonia.

Flowers in compound panicles; fruit small, glabrous; pericarp mealy.

4. Lithraea. 


\section{TOXICODENDRON. PoISON OAK.}

I. Toxicodendron diversifolium (Torr. \& Gray) Greene, Leaflets 1: II9. 1905.

Rhus diversiloba Torr. \& Gray, Fl. N. Am. 1: 218. 1838.

Type locality: "Borders of woods, etc. Oregon," and "California."

Distribution: Western Washington, southward to northern Lower California. Several species have been segregated from this by Greene but I can detect no specific differences between the specimens which I have cited and those from farther north. In any section there is marked variation in the foliage and pubescence, so that these characters cannot be relied upon, within certain limits, in making specific distinctions. Upper Sonoran.

Specimens examined: Santa Barbara, Elmer 3940; Fort Tejon, Abrams है McGregor 298; Red Reef Canyon, Topatopa Mountains, Abrams है McGregor 144; Sulphur Mountain, Abrams छे McGregor 46; San Gabriel, Bigelow, 1854; Pasadena, Jones 3206.

Rhus glabra L. has been reported by Parish (Bot. Gaz. 38: 46I) from "Chino Cañon, near Palm Springs, at the desert base of San Jacinto Mt.," where it was collected by Hasse.

\section{SCHMALTZIA. SQUAW Berry.}

Fruit not villous.

Fruit villous.

Herbage minutely puberulent.

Herbage densely soft-pubescent.
I. S. cruciata.

2. S. straminea.

3. S. malacophylla.

I. Schmaltzia cruciata Greene, Leaflets 1: 139.1905.

Type locality: "Hot Springs in the northern part of San Diego Co., Calif."

Distribution: I have not been able to examine the original specimens upon which this species was based, nor have I seen any plants that answer the description. The validity of the numerous species proposed by Greene, for what has passed as S. trilobata (Rhus trilobata) can only be judged by thorough field work and the critical examinations of a large series of specimens. Upper Sonoran. 
2. Schmaltzia straminea Greene, Leaflets 1: 139. 1905.

Type locality: "Along Lytle Creek, San Gabriel Reserve, Calif."

Distribution: The puberulent form is apparently confined to the foothills and chaparral of the interior part of southern California. Upper Sonoran.

Specimens examined: Red Reef Canyon, Topatopa Mountains, Abrams छ McGregor 149; Oakgrove Canyon, Liebre Mountains, Abrams है McGregor 320.

3. Schmaltzia malacophylla Greene, Leaflets 1: I38. 1905.

Type locality: "Griffith Park, Los Angeles Co., Calif."

Distribution: Apparently restricted to the coastal foothills. The lobation of the leaves is variable, and there seems to be no distinguishing characters between this and the preceding species except pubescence, the stability of which is doubtful. Upper Sonoran.

Specimens examined: North slope of the Santa Monica Mountains, between Encino and Cahuenga Pass, Abrams 1310; Sepulveda Canyon, Santa Monica Mountains, Abrams 3113; Playa del Rey (Ballona Harbor), Abrams 286; Arroyo Seco, near Pasadena, Grinnell, July 30, 1903.

\section{NEOSTYPHONIA. LEMONADE BERRY.}

Leaves oval, very obtuse at both ends.

Leaves ovate, acute at apex.
1. N. integrifolia.

2. N. ovata.

I. Neostyphonia integrifolia (Nutt.) Shafer, in Britton, N. Am. Trees 612. 1908.

Styphonia integrifolia Nutt. Torr. \& Gray, Fl. N. Am. 1: 220. 1838.

Rhus integrifolia Benth. \& Hook.; S. Wats. U. S. Geograph. Surv. 6: 84. 1878 .

Styphonia serrata Nutt. in Torr. \& Gray, Fl. N. Am. 1: 220. 1838.

Type locality: "On the margins of cliffs near the sea around San Diego and Santa Barbara."

Distribution: Santa Barbara, southward through northern Lower California. In the northern part of its range it is confined to the sea-coast, but southward especially in San Diego County it 
extends inland even to the desert slopes of the Cuiamaca Mountains. Upper and Lower Sonoran.

Specimens examined: Santa Barbara, Nuttall; Parry, I 850; Elmer 3898; Los Angeles, Franceschi, 1893; Playa del Rey, Abrams 287; Big Tejunga Wash, San Fernando Valley, Abrams 1385; Claremont, Baker 4156; Ysidora, Abrams 3307; San Diego, Brandegee (distributed by C. F. Baker 818 ); Herre, July 23, 1902.

\section{Neostyphonia ovata (S. Wats.).}

Rhus ovata S. Wats. Proc. Am. Acad. 20: 358. 1885.

Type locality: "On hills and mountains, away from the coast, from San Diego to Los Angeles County, the Cantillas Mountains in Lower California, and in Southern Arizona; also on Santa Catalina Island."

Distribution: Santa Ynez Mountains, southward through the chaparral belt of the coastal slope to northern Lower California; also on the islands of the coast of southern California, and in Arizona. Upper Sonoran.

Specimens examined: Santa Ynez Mountains, Brandegee; Dunn, 1891; Elmer 3904; San Fernando Mountains, near Chatsworth, Abrams 1360; Sepulveda Canyon, Santa Monica Mountains, Abrams 2559; Sawpit Canyon, San Gabriel Mountains, Dudley, Dec. 1907; hills near Monrovia, Baker 4147; Lone Pine Canyon, San Gabriel Mountains, Abrams E McGregor 677; Redlands, Parish, April 2r, I89I; Fallbrook, Jones 33I8; between Campo and Potrero, Abrams 3719.

\section{Lithraea. California sumac.}

I. Lithraea laurina (Nutt.) Walp. Rep. 1: 55I. 1842. Rhus laurina Nutt.; Torr. \& Gray, Fl. N. Am. 1: $219 . \quad$ I838.

Type locality: "On bushy plains, near St. Barbara, California."

Distribution: Southern slopes of the Santa Ynez Mountains southward to northwestern Lower California, and on the islands as far south as Cedros Island. In southern California this species is confined chiefly to the lower portions of the chaparral belt. Upper and Lower Sonoran.

Specimens examined: Santa Barbara, Elmer 4015; Mountain Drive, Santa Barbara, Abrams 4I54; Santa Monica Canyon, Abrams 2192; Scoville's Hill, Pasadena, Grinnell, July 3, 1903; 
near San Gabriel, Bigelow, March 23, I854; Little Santa Anita Canyon, San Gabriel Mountains, Abrams 2639; near Monrovia, Dudley, Dec. 8, 1907; hills near Elsinore Lake, Dutton, June 2, I898; Jamul, Susan G. Stokes, June I9, r895; San Diego, Herre, July 23, 1902; Chandler 4122.

\section{RHAMNACEAE. Buckthorn Family.}

Fruit drupaceous, free from the calyx.

Drupe enclosing a single stone.

I. Condalia.

Drupe enclosing 2-4 nutlets.

2. Rhamnus.

Fruit becoming nearly or quite dry, partly inferior.

Calyx-lobes deciduous; style elongated, 3-lobed.

Calyx-lobes persistent; style short, notched.

3. Ceanothus.

4. Adolphia.

\section{CONDALIA.}

Petals none; sepals persistent; drupe $5 \mathrm{~mm}$. long. Petals present; sepals deciduous.

Drupe $5 \mathrm{~mm}$. long, beakless; herbage canescent.

Drupe $15 \mathrm{~mm}$. long, beaked; herbage glabrous.

I. C. spathulata.

2. C. divaricata.

3. C. Parryi.

I. Condalia spathulata A. Gray, Pl. Wright. 1: 32 . 1852.

Type locality: "On the Rio Grande, Texas; and prairies on the San Felipe."

Distribution: Southwestern Texas to the Colorado Desert of southern California. I have not seen any specimens of this from southern California, but according to Trelease (A. Gray, Syn. Fl. 1, pt. I: 403) it has been collected at Mesquite, Parish 793. Lower Sonoran.

2. Condalia divaricata A. Nelson, Bot. Gaz. 47: 427 . I909.

Zizyphus lycoides canescens A. Gray, U. S. Geog. Sur. 6: 82. 1878. Condalia lycoides canescens Trelease, A. Gray, Syn. Fl. 1, pt. I: 403. 1897 .

Type locality: "Las Vegas, Nevada."

Distribution: Southern Nevada southward through western Arizona and the deserts of southern California to northern Lower California. Lower Sonoran.

Specimens examined: I have not seen any specimens from southern California, but according to Trelease (l. c.) it has been collected by Parish at Mammoth Tank in the Colorado Desert. 
3. Condalia Parryi (Torr.) Weberbauer, in Engler \& Prantl, Nat. Pflanzenf. 3, ab. 5: 404. 1895 .

Zixyphus Parryi Torr. Bot. Mex. Bound. 46. 1859.

Type locality: "Gravelly ravines near San Felipe, California."

Distribution: Western borders of the Colorado Desert southward to Lower California. Lower Sonoran.

Specimens examined: Morongo Canyon, altitude 1000 meters, Parish 2969; Whitewater Canyon, Pringle, March 25, 1882; San Felipe, Parry, 1850; Jacumba Hot Spring, Abrams 3659.

\section{RHAMNUS. BUCKTHORN OR COFFEE BERRY.}

Flowers polygamo-dioecious; petals none; leaves pungently toothed.

Branches spinescent; leaves obovate, 6-12 mm. long; calyx-lobes triangular.

I. R. crocea.

Branches not spinescent; leaves $\mathbf{1 2 - 4 0} \mathrm{mm}$. long; calyz-lobes lanceolate.

Leaves becoming glabrous and shiny; anthers I $\mathrm{mm}$. long.

2. R. ilicifolia.

Leaves more or less pilose; anthers $0.5 \mathrm{~mm}$. long. 3. R. pilosa.

Flowers perfect; petals minute, emarginate; leaves not pungently toothed.

Leaves green and glabrous beneath.

4. R. californica.

Leaves canescent beneath.

Leaves entire, tomentulose beneath. $\quad$ 5. $R$. tomentella.

Leaves serrulate, hirsutulose beneath. 6 . R. cuspidata.

I. Rhamnus crocea Nutt. in Torr. \& Gray, Fl. N. Am.

1: $261 . \quad 1838$.

Type locality: "Around Monterey, California."

Distribution: Coast Ranges of central California, southward to northern Lower California. In southern California it occurs on dry exposed ridges in the lower part of the chaparral belt, especially on the footslopes of the mountains. Upper and Lower Sonoran.

Specimens examined: Montecito, Franceschi, r894; Big Tejunga Wash, Abrams 1370; Arroyo Seco, near Pasadena, Grinnell, July 30, 1903; mesas near San Bernardino, Parish, May 26, r898; San Diego, Jones 3087; Brandegee, 1889; Coronado, Dunn, April 7, I891; Tia Juana, Abrams 3499.

2. Rhamnus ilicifolia Kell. Proc. Calif. Acad. 2: 37.1863. Rhamnus crocea ilicifolia Greene, Fl. Fran. 79. I89I. Type locality: "Vicinity of Clear Lake." 
Distribution: Coast Ranges from Lake County southward to the southern boundary of the State. In southern California this is a larger, less rigid bush than $R$. crocea, with leaves that very closely resemble those of Laurocerasus ilicifolia. It is a common shrub in the chaparral belt of the coastal slope. Upper Sonoran

Specimens examined: Santa Barbara, Parry; Santa Ynez Mountains, Brandegee, May, I888; Sulphur Mountain Spring, Abrams E McGregor 39; Saugus, Elmer 3649; Sepulveda Canyon, Santa Monica Mountains, Abrams 3Ir4; Pasadena, Brandegee, May, 1888; San Gabriel Canyon, Abrams I020; Claremont, Baker 3653; Pasadena, Grinnell, Aug. I, 1903; Oakgrove Canyon, Liebre Mountains, Abrams E McGregor 333; Cleghorn Canyon, San Bernardino Mountains, Abrams \& McGregor 710 ; Temecula Canyon, Greene, June, I889; Campo, Abrams 3587.

3. Rhamnus pilosa (Trelease) Abrams, Bull. Torr. Bot. Club 37: I53. I910.

Rhamnus crocea pilosa Trelease; Curran, Proc. Calif. Acad. II. 1: 25I. I 888.

Type locality: "Santa Maria Valley, in the mountains back of San Diego."

Distribution: Mountains and foothills of San Diego County. Upper Sonoran.

Specimens examined: Mountains east of San Diego, Parry, 1859; San Diego, Parry; 1850; vicinity of San Ysabel, Henshaw 235; San Felipe, Susan G. Stokes, July 26, I895.

4. Rhamnus californica Esch. Mem. Acad. Petersb. 10: 285. I823.

Rhamnus oleifolia Hook. Fl. Bor. Am. 1: I23, pl. 44. 1833. Endotropis oleifera Raf. Sylva Tellur. 31. 1838.

Rhamnus laurifolius Nutt. in Torr. \& Gray, Fl. N. Am. 1: 260. I 848.

Perfonon laurifolium Raf. Sylva Tellur. 29. $\quad$ I838.

Frangula californica A. Gray, Gen. Ill. 2: 178. 1849.

Rhamnus Purshiana californica Rehder, in Bailey, Cyclop. Am. Hort. I510. 1902.

Type locality: "In Novae Californae fruticetis."

Distribution: In the Coast Ranges, from Mendocino County 
southward to San Bernardino County. In southern California this is a common shrub in the chaparral on the mountains and foothills, especially toward the coast. Upper Sonoran.

Specimens examined: Santa Barbara, Nuttall; Torrey, 1850; Pasadena, Jones, May 8, 1882; Sepulveda Canyon, Santa Monica Mountains, Abrams 254I; Claremont, Baker 3443; San Gabriel Canyon, Leiberg 3404; Arroyo Seco, above Devil's Gate, Abrams 1427; Mill Creek, San Bernardino Mountains, Abrams \& McGregor 822; Cleghorn Canyon, San Bernardino Mountains, Abrams है McGregor 709.

5. Rhamnus tomentelia Benth. Pl. Hartw. 303. I848.

Rhamnus californica tomentella Brew. \& Wats. Bot. Calif. 1: ror. I876.

Rhamnus Purshiana tomentella K. Brand. Zoe 1: 244. I890.

Type locality: "In montibus Sacramento."

Distribution: In the chaparral belt of the Sierra Nevada, extending southward to northern Lower California, and eastward to Arizona. In southern California this species replaces $R$. californica on the more interior mountains away from the influence of the coast fogs. Upper Sonoran.

Specimens examined: Mount Pinos, Elmer 3817; Sespe Creek, near Ten Sycamore Flat, Abrams छ McGregor I66; Sisar Canyon, Topatopa Mountains, Abrams \& McGregor 66; foothills of the San Bernardino Mountains, Parish, June 26, I898; San Diego, Parry, I850; Palomar Mountain, Mc Clatchie, July, I896; near Foster's, Abrams 737I; Cuiamaca Mountains, between Julian and Cuiamaca, Abrams 3962; Buckman's Springs, Susan G. Stokes, July I8, 1895; hills near Campo, Abrams 3695.

6. Rhamnus cuspidata Greene, Leaflets 1: 64. 1904 .

Type locality: "Near Tehachapi."

Distribution :Tehachapi Mountains, southward along the desert slopes of the San Gabriel and the San Bernardino Mountains. Upper Sonoran.

Specimens examined: Rock Creek, Abrams \& McGregor 532, 621; Oakgrove Canyon, Liebre Mountains, Abrams छ McGregor 327; Lone Pine Canyon, San Gabriel Mountains, Abrams छ̋ McGregor 664; Hathaway Flat, San Bernardino Mountains, Abrams E McGregor 809. 


\section{CEANOTHUS. Wild lilac.}

*Stipules thin and mosily fugacious; leaves alternate; capsules without dorsal or apical horns; flowers racemose or paniculate.

Leaves"deciduous, entire, pinnately veined, or somewhat 3-nerved in the first species; twigs not at all spinescent; flowers white, paniculate.

Leaves ovate, pubescent above; capsule smooth, slightly crested, 4-5 mm. broad.

I. C. iniegerrimus puberulus.

L:aves elliptic, glabrous above; capsules roughened, rather prominently crested, $7 \mathrm{~mm}$. broad.

2. C. Palmeri.

Leaves evergreen; flowers blue or rarely white.

Leaves pinnately veined, elliptic, entire; twigs slender, spinescent; arborescent shrub.

Leaves 3-nerved, ovate-lanceolate to ovate.

3. C. spinosus.

Twigs stiff and spinescent; leaves entire and glabrous (except in no. 5).

Erect branching shrubs, racemes elongated.

Leaves often sparsely glandular-toothed, pubescent above.

Leaves entire, glabrous above.

4. C. divaricatus.

4a. C. divaricatus eglandulosus.

Spreading, flat-topped shrub; twigs pale or olive color; raceme short, spreading.

5. C. cordulatus.

Twigs not at all spinescent; leaves glandular-toothed, pubescent.

Large arborescent shrubs or small trees.

Capsules glabrous.

Leaves glabrous above. 6. C. sorediatus.

Leaves pubescent above.

Leaves minutely velvety-pubescent above, densely white-tomentose beneath.

\section{C. tomentosus.}

Leaves somewhat hirsute above, not velvety, hirsute beneath; twigs hirsute or villous.

8. C. oliganthus.

Capsules glandular-villous; leaves and twigs pubescent.

Low shrubs, 3-1o dm. high.

9. C. Orcuttii.

Leaves elliptic or narrowly ovate, $2 \mathrm{~cm}$. long or less.

Io. C. austro-montanus.

Leaves round-ovate, their veins deeply impressed on the back, I cm. long or less, villous.

I1. C. impressus.

**Stipule-bases persistent, thick and corky or spongy; capsule usually with dorsal or apical horns as well as crests; flowers umbellate, white or rarely blue (no. 15).

Leaves alternate.

Leaves narrowly obovate, cuneate, entire; capsule 7-10 mm. broad, horns dorsal, stout.

12. C. megacarpus. 
Leaves broadly obovate, usually denticulate; capsule $6 \mathrm{~mm}$. broad, neither crested nor horned. $\quad$ 13. C. verrucosus.

Leaves opposite.

Horns of capsules dorsal, spreading, slender; leaves usually toothed, often concave, tomentose to nearly glabrous above.

Horns near the summit, erect.

14. C. vestitus.

Leaves pungently toothed; horns stout.

Twigs and leaves glabrous or sparsely pubescent, the latter prominently toothed and holly-like; flowers b!ue.

I5. C. Jepsoni.

Twigs and under surface of leaves tomentose, the latter with shallow teeth; flowers white.

Venation on under surface of leaves hidden by the dense tomentum; leaves strongly revolute.

I6. C. crassifolius.

Venation distinct through the fine tomentum; leaves not revolute.

I6a. C. crassifolius planus.

Leaves entire; canescent below, with short, incurved hairs; horns rather slender.

17. C. cunealus.

I. Ceanothus integerrimus puberulus (Greene).

Ceanothus puberulus Greene, Leaflets 1: 66. 1904.

Type locality: "Altitude of 4000 and 5000 feet in the San Bernardino Mountains."

Distribution: Frazier Mountain southward to the San Jacinto Mountains. Transition.

This southern plant differs from the typical form in being pubescent on the upper surface of the leaves, since this character is not constant its true relation seems best expressed in the varietal rank.

Specimens examined: Goodnough Meadow, Dudley 4755; canyon near Elizabeth Lake, Dudley 44I9; Liebre Mountain, Abrams छ๋ McGregor 369; Mount Gleason, Elmer 3595; Mount Wilson, Grant 149; North Baldy, altitude 1800 meters, Abrams E $M c$ Gregor 585; Lytle Creek Canyon, I740 meters, Hall, May, I899; Cañon Diablo, Parish 4603; Huston's Flat, Shaw E' Illingsworth I57; Cleghorn Canyon, Abrams E McGregor 712; Hathaway Flat, Abrams \&ै McGregor 810; summit of Mount Santiago, Abrams I843.

2. Cenanothus Palmeri Trelease, Proc. Calif. Acad.

$$
\text { II. 1: I09. I888. }
$$

Ceanothus spinosus Palmeri K. Brand. Proc. Calif. Acad. II. 4: 185. 1894 . 
Type locality: "Mountains of Southern California (Palmer, 1875, 42)."

Distribution: Mountains of Ventura County and the Cuiamaca Mountains. Transition.

Specimens examined: Topatopa Mountains, Abrams \& $M c$ Gregor 123; Cuiamaca Mountains, Palmer 23; Cuiamaca, Brandegee, June 15, 1894, and June 3, 1896; Middle Peak, Cuiamaca Mountains, Abrams 3853 .

3. Ceanothus spinosus Nutt. in Torr. \& Gray, Fl. N. Am.

$$
\text { 1: } 1838.267 .
$$

Type locality: "Mountains of St. Barbara."

Distribution: Mountains of southern California, toward the coast, from Santa Barbara County south to Orange County. Upper Sonoran.

Specimens examined: Santa Barbara, Nuttall; Parry, I850; Elmer 39I7; Franceschi, April 4, I894; Lockwood Creek, Dudley, June, 1896; Sepulveda Canyon, Santa Monica Mountains, Abrams 29I, 3II5; near Los Angeles, Davidson, I891; Trabuco Canyon, Santa Ana Mountains, Abrams 1854 .

4. Ceanothus divaricatus Nutt. in Torr. \& Gray, Fl. N. Am.

$$
\text { 1: } 266 . \quad \text { I } 838 \text {. }
$$

Type locality: "Mountains of St. Barbara, California, and also near the town."

Distribution: Mountains of Monterey County, southward to the San Bernardino Mountains. Upper Sonoran.

Specimens examined: Santa Barbara, Nuttall; Douglas; Brewer 286; Red Reef Canyon, Topatopa Mountains, Abrams छ McGregor I57; Sisar Canyon, altitude 1050 meters, Abrams E $M c$ Gregor 63; Hines Peak, Topatopa Mountains, Abrams छ McGregor 83; Cold Creek, San Bernardino Mountains, altitude I 500 meters, Abrams Eं McGregor 828 .

4a. Ceanothus divaricatus eglandulosus Torr. Pacif.

$$
\text { R. Rep. 4: 75. } 1857 .
$$

Ceanothus eglandulosus Trelease, Proc. Calif. Acad. II. 1: Io. I 888.

Ceanothus leucodermis Greene, Kew Bull. 1895: I5. I895.

Type locality: "On mountains near San Gabriel" and "Cohon Pass." 
Distribution: Liebre Mountains, southward to northern Lower California. This is one of the characteristic shrubs of the chaparral on the interior mountains in southern California. Upper Sonoran.

Specimens examined: Near San Gabriel, Bigelow, March 22, 1853 (type); Sawpit Canyon, San Gabriel Mountains, Dudley, Dec. 1907; Mount Wilson trail, Abrams, July 19, 1906; near the summit of Mount Wilson, Abrams 2609; Mount Gleason, Elmer 36ro; Big Tejunga Wash, Abrams I37I; Oakgrove Canyon, Liebre Mountains, Abrams Eे McGregor 328; Cajon Pass, Bigelow, 1853; Cañon Diablo, Parish 4694; Cleghorn Canyon, San Bernardino Mountains, Abrams $\mathcal{\sigma}^{\circ}$ McGregor 7II; Santa Ana Mountains near Elsinore, Baker 4I44; Abrams, July 21, I908; Nuevo, Brandegee Io; Cottonwood grade, near Potrero, Abrams $373 I$.

5. Ceanothus cordulatus Kell. Proc. Calif. Acad. 2: i24, pl. 39. I86r.

Type locality: "Brought by Dr. J. A. Veatch from Washoe."

Distribution: Sierra Nevada Mountains, southward through the mountains of southern California, where it is rather common in the higher altitudes of the Transition and Canadian Zones.

Specimens examined: North Baldy, altitude 2250 meters, Abrams है McGregor 6I8; Mount San Antonio, altitude 2000 meters, Hall 1217; near Bear Valley, Abrams 2866; Mount San Antonio, Abrams 2706; Mount San Jacinto, Hasse 5660.

6. Ceanothus sorediatus Hook. \& Arn. Bot. Beech. 328. I840.

Type locality: Collected by Douglas in California.

Distribution: Coast Ranges of central California from Solano County southward to northern Santa Barbara County, also in the Sah Gabriel Mountains. Upper Sonoran.

Specimens examined: Sawpit Canyon, San Gabriel Mountains, Dudley, Dec. 1907.

7. Ceanothus tomentosus Parry, Proc. Davenp. Acad. 5: 190. I889.

Ceanothus oliganthus tomentosus K. Brand. Proc. Calif. Acad. II. 4: 198. I 894.

Type locality: "Brown sandstone ledges, Ione, Amador County." Distribution: Foothills of the Sierra Nevada in Amador County, 
in the chaparral of the San Bernardino Mountains, and in the San Diego region. Upper Sonoran.

Specimens examined: Edgar Canyon, Parish 4I03; Mill Creek Canyon, Parish 2023, 2088; Encinitas, Brandegee, March 28, I894; San Diego, Brandegee 33; Nuevo, Brandegee 36; San Dieguito, Abrams 3732; Cottonwood grade, Abrams 3379.

8. Ceanothus oliganthus Nutt. in Torr. \& Gray, Fl. N. Am.

$$
\text { 1: } 266 . \quad \text { I } 838 \text {. }
$$

Ceanothus hirsutus Nutt. in Torr. \& Gray, Fl. N. Am. 1: 266. I838.

Type locality: "Bushy woods on the hills of St. Barbara."

Distribution: In the chaparral of the mountains of Santa Barbara County, southward to the San Gabriel Mountains, where it extends at least as far eastward as Monrovia. This species is therefore confined chiefly to the coastal mountains. Upper Sonoran.

Specimens examined: Santa Barbara, Nuttall; Brewer 289; Franceschi, April 2, 1894; Brandegee 30; Santa Ynez Mountains, Elmer 3776; Abrams, March 6, 1909; Pasadena, Brandegee 3I; Mount Wilson trail, Abrams I504; Millard's Canyon, Abrams 292; Sawpit Canyon, San Gabriel Mountains, Dudley, Dec., 1907.

9. Ceanothus Orcuttil Parry, Proc. Davenp. Acad. 5: 193. I889.

Ceanothus hirsutus Orcuttii Trelease, in A. Gray, Syn. Fl. 1, pt. I: 4I4. 1897.

Type locality: "High Mountains east of San Diego, C. R. Orcutt."

Distribution: Cuiamaca Mountains of San Diego County. Borders of the Transition and Upper Sonoran.

Specimens examined: Nuevo, Brandegee 32; between Julian and Cuiamaca, Abrams 3965.

10. Ceanothus austro-montanus sp. nov.

Low, erect shrub, 3 meters high or less; branchlets reddish or grayish-brown, short-pubescent and glandular; petioles $3 \mathrm{~mm}$. long or less; leaves oblong to narrowly ovate, $8-12 \mathrm{~mm}$. long, 4-6 $\mathrm{mm}$. wide, conspicuously glandular-toothed, minutely appressedpubescent above, pale beneath and pubescent on the veins; peduncles $3-5 \mathrm{~cm}$. long; racemes a half to a third as long; fruiting 
pedicels $5 \mathrm{~mm}$. long; calyx-lobes broadly triangular, nearly $2 \mathrm{~mm}$. high; capsule $3 \mathrm{~mm}$. broad, slightly longer, very shallowly lobed; dorsal crests inconspicuous.

Related to C. foliosus Parry of the North Coast Ranges (Marin to Mendocino Counties); but that species has a deeply lobed and relatively broader capsule, and smaller, narrower calyx-lobes.

Type: Coniferous forests, between Julian and Cuiamaca, Abrams 3966, July I, 1903. The type specimen is deposited in the Stanford University Herbarium.

Distribution: Cuiamaca Mountains, southern California. Transition.

II. Cenanothus impressus Trelease, Proc. Calif. Acad.

\section{1: I I2. I 888 .}

Ceanothus dentatus impressus Trelease, in Gray, Syn. Fl. 1: pt. I: 4I 5. I 897.

Type locality: "Santa Barbara County."

Distribution: Coastal region of Santa Barbara and San Luis Obispo Counties. Upper Sonoran.

Specimens examined: Surf, Elmer 3870.

12. Ceanothus megacarpus Nutt. N. Am. Sylva, 5: 46.1846. Ceanothus macrocarpus Nutt. in Torr. \& Gray, Fl. N. Am. 1: 267. I838. Not Cav. I794.

Type locality: "Mountains of St. Barbara, California."

Distribution: Mountains and foothills especially toward the coast, from Santa Barbara south to the Santa Monica Mountains. Upper Sonoran.

Specimens examined: Santa Barbara, Nuttall; Brandegee 89; Elmer 3869; Mountain Drive, Abrams 4124; Santa Catalina Island, Brandegee 88; Sepulveda Canyon, Santa Monica Mountains, Abrams 2560.

13. Cenanothus verrucosus Nutt. in Torr. \& Gray, Fl. N. Am. 1: $267 . \quad$ I 838 .

Type locality: "Low hills near the coast, St. Diego, California."

Distribution: Dry mesas and hills in the vicinity of San Diego, and southward into northern Lower California. Lower Sonoran.

Specimens examined: San Diego, Nuttall; Parry, I850; Encinitas, Brandegee 9r; hills near San Dieguito, Abrams 3739; mesas near San Diego, Susan G. Stokes, May 28, I895. 
14. Cennothus vestitus Greene, Pittonia 2: Ior. I89o.

Type locality: "Borders of pine forests on the mountains near Tehachapi, Kern Co., Calif."

Distribution: Southern Nevada, southward to the San Bernardino Mountains. In southern California this species is confined chiefly to the desert slopes of the mountains in the piñon belt. Upper Sonoran.

Specimens examined: Mount Pinos, altitude 1800 meters, Abrams छ McGregor 260; Pine Creek near Mutau Flat, Abrams E McGregor 194; Oakgrove Canyon, Liebre Mountains, Abrams छ McGregor 334; Rock Creek, Abrams Eง McGregor 567; eastern slope of Mount San Antonio, altitude 2400 meters Abrams 27I7; eastern base of the San Jacinto Mountains Hall 2156; Cahuilla Valley, Hall II64; San Felipe Canyon, Brandegee II4; between Campo and Jacumba Hot Spring, Abrams 3700.

15. Cennothus Jepsoni Greene, Man. Bay-Region 78. I894.

Type locality: "Open hills in Marin Co., near San Geronomo, and northward."

Distribution: This species has only been known from the Coast Ranges north of San Francisco Bay, but the specimens cited below seem identical. The species is closely related to $C$. pinetorum of the southern Sierra Nevada, but that has much more prominent stipules. Upper Sonoran.

Specimens examined: Hills west of Pomona, Baker $400 \pi$.

16. Ceanothus crassifolius Torr. Pacif. R. Rep. 4: 75. 1857 .

Type locality: "Mountains south of Los Angeles."

Distribution: A common shrub in the chaparral from Santa Barbara County, southward to northern Lower California. Upper Sonoran.

Specimens examined: Newhall, Brandegee 85; Mount Lowe, Grant I147; San Fernando Mountains, near Chatsworth, Abrams I364; Cajon Pass, Bigelow, March 16, I853; Beaumont, Parish 4104, Lone Pine Canyon, San Gabriel Mountains, Abrams E McGregor 672; Santiago Canyon, Helen D. Geis, April, I902; near Foster's, Abrams 3767; Nuevo, Brandegee 84. 


\section{6a. Ceanothus crassifolius planus var. nov.}

Like the type in structural characters but leaves not revolute on the margin, and much less tomentose beneath, the venation being very evident through the sparse tomentum. An apparent geographic variation.

Type: Red Reef Canyon, Topatopa Mountains, Ventura County, Abrams \& McGregor I24, June 8, 1908. The type specimen is deposited in the Stanford University Herbarium.

Distribution: Mountains of Santa Barbara and Ventura Counties. Upper Sonoran.

Specimens examined: Santa Ynez Mountains, Elmer 3758; near Sespe Hot Springs, Dudley 4777; Red Reef Canyon, Topatopa Mountains, Abrams Eे McGregor I24.

I7. Ceanothus cuneatus (Hook.) Nutt. in Torr. \& Gray, Fl. N. Am. 1: 267. I 838 .

Rhamnus cuneatus Hook. Fl. Bor. Am. 1: 124. 1829.

Type locality: "Near the sources of the Multonomak River, in sandy soils growing under the shade of Pinus Lambertiana."

Distribution: Southern Oregon southward throughout California. Upper Sonoran.

Specimens examined: Vicinity of Fort Tejon, Abrams \& McGregor 295; Cuddy's ranch, Dudley 4485; Sisar Canyon, Topatopa Mountains, Abrams E McGregor 67; near Azusa, Abrams 3128; Elizabeth Lake, Abrams E McGregor 4IO; Colton, Jones 3176; San Bernardino, S. B. छ W. F. Parish IOI5; Claremont, Baker 237; hills near Campo, Abrams 3500; San Clemente Island, Blanche Trask 198.

\section{ADOLPHIA.}

I. Adolphia californica S. Wats. Proc. Am. Acad. 11: i26. I876.

Type locality: "At Solidad and Chollas Valley, near San Diego and near Monterey." The last station is unquestionably an error.

Distribution: From the vicinity of San Diego southward through northern Lower California. Lower Sonoran.

Specimens examined: Near San Diego, Parry, I850; Soledad Palmer 44; Jones 3132; Chollas Valley, Cleveland; Tia Juana, Abrams 3481 . 


\section{$\left(4^{16}\right)$}

VITACEAE. Grape Family.

I. VITIS. Grape.

I. Vitis Girdiana Munson, Proc. Soc. Prom. Agr. Sci. 59. 1887.

Type locality: "San Diego Co." and "Los Angeles Co. California."

Distribution: Along streams on the coastal and desert slopes of the southern California mountains, from Santa Barbara southward. Upper Sonoran.

Specimens examined: Sawpit Canyon, San Gabriel Mountains, Alice Cooper, Oct. 4, 1908; near Monrovia, Dudley, Nov. 1907; Lytle Creek Canyon, Abrams 1955; West Fork of Deep Creek, San Bernardino Mountains, Abrams E McGregor 723; vicinity of San Bernardino, Parish 50I3; Jamul Valley, Susan G. Stokes, June 19, 1895; between Foster's and Ramona, Abrams 3766.

MALVACEAE. Mallow Family.

Stigmas linear.

Stigmas capitate.

Seeds not comose; fruit with a central axis.

Seeds comose; fruit without a central axis.
I. Lavatera.

2. Malacothamnus.

3. Hibiscus.

I. LAVATERA. Tree mallow.

1. Lavatera assurgentiflora Kell. Proc. Calif. Acad. 1: i4. 1854 .

Type locality: "Island of Anacapa, off the coast of Santa Barbara."

Distribution: A native of the islands off the coast of southern California; cultivated on the mainland where it sometimes appears as an escape.

\section{MALACOTHAMNUS. Bush mallow.}

Calyx and herbage clothed with very short-rayed stellate pubescence.

Leaves green above, sparsely stellate-pubescent.

Inflorescence mostly simple; flower-clusters nearly sessile.

1. M. fasciculatus.

Inflorescence branched; flower-clusters lax.

ra. M. fasciculatus splendidus.

Leaves hoary on both surfaces, with a dense soft stellate-pubescence.

2. M. Nuttallii. 
Calyx and herbage clothed with long-rayed hispid-like stellate pubescence.

Leaves $6-8 \mathrm{~cm}$. broad, rugose; calyx-tube not obscured by the pubescence; calyx-lobes triangular.

3. M. Davidsoni.

Leaves $2-3 \mathrm{~cm}$. broad; nut rugose; surface of calyx-tube completely hidden by the dense hoary hispid pubescence; calyx-lobes lanceolateacuminate.

4. M. orbiculatus.

I. Malacothamnus fasciculatus (Nutt.) Greene, Leaflets 1: 208. 1906.

Malva fasciculata Nutt. in Torr. \& Gray, Fl. N. Am. 1: 226. $\quad$ I838. Malvastrum fasciculatum Greene, Fl. Fran. 108. I891. Malvastrum Thurberi A. Gray, Mem. Am. Acad. II. 5: 307. 1855. Type locality: "St. Barbara." Nuttall's specimens are like the form occurring at San Diego, where he probably obtained his specimens, as the species has not since been found at Santa Barbara.

Distribution: The typical form seems to be confined to southwestern San Diego County. Upper and Lower Sonoran.

Specimens examined: "St. Barbara" (?), Nuttall; San Diego, Brandegee (distributed by Baker I626); Orcutt, I884; Palmer 25; Abrams 3429; Chollar Valley, Susan G. Stokes, June I 5, I895; Lemon Grove road, Chandler 5298.

\section{I a. Malacothamnus fasciculatus splendidus. (Kell.)}

Malvastrum splendidum Kell. Proc. Calif. Acad. 1: 67. 1855.

Malvastrum Thurberi laxiflorum A. Gray, Proc. Am. Acad. 22: 291. I887.

Type locality: Contributed by "Mr. M. A. Wallace of Los Angeles," who probably collected it on the neighboring hills.

Distribution: Santa Monica and San Fernando Mountains, southward to the Santa Ana Mountains and eastward to the San Bernardino Mountains. Upper Sonoran.

Specimens examined: Cahuenga Pass, Davidson, May I, I892, and April 10, 1900; Abrams 1246; Verdugo Hills, Abrams 1382; near San Bernardino, Parish, June 15, I898, Laguna, Orange County, Abrams 178 .

\section{Malacothamnus Nuttallii sp. nov.}

Shrub, 2-3 meters high; branches erect or ascending, canescent with a short-rayed stellate pubescence; petioles $1.5^{-2.5} \mathrm{~cm}$. long; leaves acutely 5-lobed, crenate-serrate, slightly or not at all cordate, $2.5-4 \mathrm{~cm}$. long, equally hoary on both surfaces with a close, 


\section{$(4 \mathrm{I} 8)$}

soft, short-rayed, stellate pubescence; inflorescence loose, compound; bractlets subulate, $2-3 \mathrm{~mm}$. long; calyx I cm. long; lobes triangular, acute, equaling the tube; petals rose-purple, twice the length of the calyx; carpels stellate-pubescent on the summit, obovate, $3 \mathrm{~mm}$. high.

This species was first discovered by Nuttall who considered it an undescribed species of Malva, but the name proposed by him over seventy years ago has never been published and now is not tenable. I therefore take pleasure in naming this long unrecognized but strikingly distinct species in honor of that acute observer and enthusiastic collector.

Type: Casitas Pass, Ventura County, Abrams, July 25, 1908. The type specimen is deposited in the Herbarium of Stanford University.

Distribution: Southern slopes of the Santa Ynez Mountains. Upper Sonoran.

Specimens examined: Foothills of the Santa Ynez Mountains, near Santa Barbara, Elmer 3730; Franceschi, Nov. 1909; Greene, July, 1886; Casitas Pass, Abrams, July 25, 1908.

3. Malacothamnus Davidsoni (Robinson) Greene, Leaflets 1: 208. I 906.

Malvastrum Davidsoni Robinson, in A. Gray, Syn. Fl. 1, pt. I: 3 I 2. 1897.

Type locality: The type specimens were collected by Dr. A. Davidson in "San Fernando Valley."

Distribution: Robinson reports this species from Antelope and Bear Valleys as well as from the San Fernando Valley. The Bear Valley specimens cited by him I have not seen, but those from Antelope Valley (Parish 1955) belong to the next species. This species is known to me only from San Fernando Valley and the adjoining La Canada. Lower Sonoran.

Specimens examined: San Fernando, Davidson, May, 1893, and June 24, I895; San Fernando wash, Davidson, 1907; Big Tejunga wash, Lyon, Aug. 1884; La Canada, Abrams I4OI.

4. Malacothamus orbiculatus Greene, Leaflets 1: 208. 1906.

Malvastrum orbiculatum Greene, Fl. Fran. 109. I89I.

Type locality: "In the mountains south of Tehachapi, Kern Co." 
Distribution: On the desert slopes of the San Bernardino Mountains northward to the Tehachapi Mountains. Upper Sonoran.

Specimens examined: Near Griffens, Lockwood Valley, Elmer 3895; between Oakgrove Canyon, and Elizabeth Lake, Abrams Eڤ McGregor 405; Antelope Valley, Parish 1955; north slope of the San Bernardino Mountains, S. B. छ W. F. Parish I39; Gold Mountain, Abrams 2070; Swartout Valley, San Gabriel Mountains, Abrams है McGregor 63I; Acton, Davidson, July 4, I892; Rock Creek, Davidson, July 4, I893.

In addition to these four mainland species there is a fifth on the islands, Malacothamnus nesioticus (Robinson) = Malvastrum nesioticum Robinson, in A. Gray, Syn. Fl. 1, pt. I: 3I2. I897. This species is intermediate between $M$. fasciculatus and $M . N u t-$ tallii, having the leaf-outline of the latter, but with the upper surface green and nearly glabrous.

\section{HibiscUS. Rose mallow.}

I. Hibiscus denudatus Benth. Bot. Sulph. 7, pl. 3. 1844 .

Type locality: "Bay of Magdalena."

Distribution: Dry gravelly ravines and slopes of the Colorado Desert, extending southward into northern Lower California, and eastward to El Paso. Lower Sonoran.

Specimens examined: Signal Mountain, Colorado Desert, Abrams 3178, and Dec. 29, I907; Palm Springs, Mrs. Hutchinson, April, I9ro.

STERCULIACEAE. Sterculia Family.

\section{FREMONTODENDRON. California slippery elm.}

i. Fremontodendron californicum (Torr.) Coville, Cont. Nat. Herb. 4: 74. I893.

Fremontia californica Torr. Pl. Frem. 5, pl. 2. 1853.

Chiranthodendron californicum Baill. Hist. P1. 4: 70. 1873.

Type locality: "Sources of the Sacramento, in the northern part of the Sierra Nevada of California."

Distribution: Western slope of the Sierra Nevada and the more interior parts of the Coast Ranges, from the vicinity of Mt. Shasta south to the Cuiamaca Mountains. Higher altitudes of the Upper Sonoran and the lower parts of the Transition. 
Specimens examined: Cuddy's ranch, Rothrock 278; San Ysabel, Henshaw, May 12, 1893; Lytle Creek Canyon, altitude 1250 meters, Abrams 2606; near Elizabeth Lake, Abrams \& McGregor 404; Soldier's Camp, near Fort 'Tejon, Abrams \& McGregor 272; Rock Creek, Abrams E० McGregor 615.

Frankeniaceae. Frankenia Family.

I. FRANKENIA. YERBA REUMA.

I. Frankenia Palmeri S. Wats. Proc. Am. Acad. 11: I24. 1876.

Type locality: "Lower California, upon the gulf side."

Distribution: Vicinity of San Diego, southward along the coast of Lower California, and on the adjacent islands. Lower Sonoran.

Specimens examined: National Ranco, near San Diego, Clereland, May II, I880; borders of salt marshes, National City, Pringle, May 3, 1882; San Diego, Herre, Aug. 8, 1902.

Another species, Frankia grandiflora, which is a perennial, herbaceous plant, is abundant in low saline ground along the coast.

FOUQUIERACEAE. Fouquiera Family.

I. FOUQUIERA. Ocotillo.

I. Fouquiera splendens Engelm. in Wisliz. Mem.

Tour. North Mex. 98. 1848.

Type locality: "From the Journada del Muerto in New Mexico, to Chihuahua, Saltillo, and Monterey."

Distribution: Desert siopes of the Cuiamaca and San Jacinto Mountains, eastward to western Texas, and south through northern Mexico. Lower Sonoran.

Specimens examined: Near Signal Mountain, Abrams 3164.

\section{CISTACEAE. Rockrose Family.}

I. HELIANTHEMUM. Rock ROSE.

Petals 4-6 mm. long; calyx-lobes $3-5 \mathrm{~mm}$. long in flower. I. H. scoparium. Petals $8-13 \mathrm{~mm}$. long; calyx-lobes $6-7 \mathrm{~mm}$. long in flower. 2. H. Aldersoni. 
I. Helianthemum scoparium Nutt.; Torr. \& Gray, Fl. N. Am. 1: $152 . \quad 1838$.

Type locality: "Dry hills around Monterey, California."

Distribution: Northern California, southward to the vicinity of Los Angeles. Upper Sonoran.

Specimens examined: Bushy hillsides, near Los Angeles, Hasse, June 5, I888; near Monrovia, Dudley, Dec. 16, I907; Etiwanda, Abrams 2664; Lytle Creek Canyon, Hall I409.

2. Helianthemum Aldersoni Greene, Erythea 1: 259. 1893. Type locality: "Mountains of the southern border of San Diego Co. Calif. among rocks in hard and sterile granitic soil."

Distribution: Foothills on the coastal slope of the San Bernardino Mountains, southward to Lower California. Upper and Lower Sonoran.

This is perhaps best considered as a geographical variation of the former. It differs chiefly in being taller and having larger floral parts, characters that do not seem constant.

Specimens examined: Vicinity of San Bernardino, Parish 4837; foothills near San Bernardino, Parish, June I5, I898; Dulzura, Abrams 3749; Potrero, Susan G. Stokes, July 19, I895.

\section{CaCtaceae. Cactus Family.}

Leaves present, but early deciduous, subulate; spines straight, sheathed; glochids present, retrorsely barbed and easily detached; stems conspicuously jointed.

r. Opuntia.

Leaves absent; spines hooked or straight, never sheathed; glochids always wanting; stems not jointed or if so not conspicuously; flowers borne on more or less vertical ribs.

Flowers nearly vertical arising from young areolae.

2. Echinocactus.

Flowers lateral, arising just above fully developed spine-bearing areolae. Ovary scaly, nearly or quite destitute of spines; tall, columnar, treelike plants.

3. Carnegiea.

Ovary and fruit spiny; stems slender-cylindric; flowers greenishyellow; seeds not tuberculate.

4. Bergerocactus.

Only the larger or taller cacti which, on account of their size, have the appearance of shrubs, are included in this list.

\section{OPUNTIA. PRICKLY PEAR.}

Joints of the stems not flattened, cylindrical (except no. 4); spines sheathed. Stems very slender; spines usually solitary in the areoles.

I. O. ramosissima.

Stems stout; spines several in each areole. 
Fruit fleshy, sparsely or not at all spiny; flowers deep red.

Branches widely spreading; spine-sheaths yellowish or rusty.

2. O. prolifera.

Branches erect or ascending, forming close compact cluster above, at length becoming reflexed; sheath-spines brightwhitish.

3. O. Bigelovii.

Fruit dry and very spiny; flowers yellow or copper color.

Stems erect, with few alternate branches; spines very slender; flowers copper color.

Stems diffusely branching; flowers yellow.

Joints ovate-clavate; fruit densely spiny.

Joints cylindrical.

4. O. acanthocarpa.

5. O. echinocarpa.

Stems usually prostrate; areoles of ovary bearing several spines.

6. O. californica.

Stems erect and bushy; areoles of ovary bearing a single spine.

7. O. bernardina.

Joints of the stem flattened, narrowly obovate to suborbicular; spines not sheathed.

Fruit dry and spiny.

8. O. hystricina.

Fruit fleshy.

Spines brownish.

Flowers yellow.

9. O. Covillei.

Flowers magenta.

Spines yellow.

I0. O. magenta.

Old trunks very spiny; seeds $2.5-3.5 \mathrm{~mm}$. broad.

II. O. chlorotica.

Old trunks becoming spineless; seeds $5-6 \mathrm{~mm}$. broad.

Areoles $35-50 \mathrm{~mm}$. apart.

Areoles $25 \mathrm{~mm}$. apart.
12. O. occidentalis.

13. O. littoralis.

I. Opuntia ramosissima Engelm. Am. Journ. Sci. II. 14: 339 . I852.

Opuntia tessellata Engelm. Proc. Am. Acad. 3: 309. 1856.

Type locality: "Gravelly soil near the Colorado, and in the desert." Collected by Dr. Parry on an expedition "from the sea-coast (San Diego) to the mouth of the Gila."

Distribution: Southern Nevada, southward to Sonora, and westward to the Mohave and Colorado Deserts. Lower Sonoran.

Specimens examined: Yuma, Toumey; Colorado Desert, Sykes. 2. Opuntia prolifera Engelm. Am. Journ. Sci. II. 14:338. I852.

Type locality: "San Diego, on arid hills and in dry creek beds."

Distribution: A maritime species extending from the vicinity of San Pedro southward to San Diego, and probably into northern Lower California. Upper and Lower Sonoran. 
Specimens examined: Mission Hills, San Diego, Abrams 3394.

3. Opuntia Bigelovii Engelm. Pacif. R. Rep. 4: 50. 1856.

Distribution: Southern Nevada and Arizona, southward to the western slopes of the Colorado Desert. Lower Sonoran.

Specimens examined: Whitewater, Rose, 1908.

4. Opuntia acanthocarpa Engelm. \& Bigel. Proc. Am. Acad. 3: 308. 1856 .

Type locality: "Mountains of Cactus Pass, between Santa Fe and the Western Colorado."

Distribution: Southern Utah and Nevada, southward through Arizona. Reported from Death Valley by Schumann. Lower Sonoran.

Specimens examined: near Campo, Sykes; Mammoth Tank, Sykes.

5. Opuntia echinocarpa Engelm. \& Bigel. Proc. Am. Acad. 3: 305. 1856 .

Type locality: "In the valley of the Lower Colorado."

Distribution: Western Arizona, westward through the Mohave and Colorado Deserts, and southward into Sonora and Lower California. Lower Sonoran.

Specimens examined: Palm Springs, Dudley, Dec. 1902; Rock Creek, desert slope of the San Gabriel Mountains, Abrams \& $M c-$ Gregor 564; Banning, Toumey, 1895; Barstow, Shaller.

6. Opuntia californica (Nutt.) Coville, Proc. Biol. Soc. Wash. 13: I19. I899.

Opuntia serpentina Engelm. Am. Journ. Sci. II. 14: 338 . 1852. Cereus californica Nutt. in Torr. \& Gray, Fl. N. Am. 1: 555. 1840.

Type locality: "Arid hills and denuded tracts near St. Diego, California, common."

Distribution: Dry mesas and foothills of southwestern San Diego County, southward into Lower California. Lower Sonoran. Specimens examined: Tia Juana, Abrams 3474. 
7. Opuntia bernardina Engelm.; Parish, Bull.

Torrey Club 19: 92. 1892 .

Type locality: "Dry hills and mesas from the Coast Range to the San Bernardino Mts., in the San Jacinto and San Bernardino Valleys."

Distribution: A characteristic plant of the interior valleys of southern California. It occurs in the vicinity of Newhall, in the San Fernando Valley, and is common in the San Bernardino and San Jacinto Valleys. Lower Sonoran.

Specimens examined: Cajon Pass, Abrams \& McGregor 699; Elsinore, Abrams, July, 1908; Warner's Ranch, Schaller; Pala, Schaller.

8. Opuntia hystricina Engelm. \& Bigel. Pacif. R. Rep. 4: 44, pl. $15, f .5-7 . \quad 1856$.

Type locality: "At the Colorado Chiquito and on the San Francisco mountains."

Distribution: Western Texas, westward to southern Nevada, and Owen's Valley, California, according to Schumann. I have seen no specimens within our limits. Lower Sonoran.

9. Opuntia Covillei Britton \& Rose, Smiths. Miscel. Coll. 50: 532. 1908.

Type locality: "San Bernardino, California."

Distribution: On the gravelly footslopes in the San Bernardino and San Jacinto Valleys, and occasionally along the desert bases of the San Gabriel Mountains. Lower Sonoran.

Specimens examined: Rock Creek, desert slope of the San Gabriel Mountains, Abrams छ McGregor $55^{8}$.

io. Opuntia magenta Griffiths, Rep. Mo. Bot. Gard. 19: 268. I908.

Type locality: "Near Redlands, California."

Distribution: This species seems to be confined to the foothills and footslopes around the San Bernardino Valley. I have not seen any specimens. Lower Sonoran. 
i i. Opuntia chlorotica Engelm. \& Bigel. Proc. Am. Acad. 3: 291. I856.

Type locality: "Western Colorado Country, between New Mexico and California, from the San Francisco Mountains to Mohave Creek."

Distribution: New Mexico, westward through Arizona and southern Nevada to the Mohave Desert, and southward to Sonora. I have not seen any southern California specimens. Lower Sonoran.

12. Opuntia occidentalis Engelm. \& Bigel. Proc.

Am. Acad. 3: 291. 1856.

Opuntia Engelmanni occidentalis Engelm. in Bot. Calif. 1: 248. 1876.

Opuntia Lindheimeri occidentalis Coult. Contr. Nat. Herb. 3: $42 \mathbf{I}$. I 896.

Type locality: "On the western slope of the California mountains, near San Diego and Los Angeles."

Distribution: The common prickly pear of the coast slope of southern California, often growing in dense thickets of considerable area. Upper and Lower Sonoran.

Specimens examined: Los Angeles, Hasse 6r69; near Pasadena, MacDougal, I906; Mesa Grande, Schaller; Pala, Schaller.

I3. Opuntia littoralis (Engelm.) Britton \& Rose, Smiths.

Miscel. Coll. 50: 529. 1908.

Opuntia Engelmanni littoralis Engelm. in Bot. Calif. 1: 248. I876. Opuntia Lindheimeri littoralis Coult. Contr. Nat. Herb. 3: 422. I 896.

Type locality: "On the coast from Santa Barbara and the islands in its gulf to San Diego, and southward."

Distribution: Bluffs along the seashore of southern California, and on the islands off the coast. Upper Sonoran.

Specimens examined: Playa del Rey, Abrams 2515.

\section{ECHINOCACTUS.}

Stems simple, large, globose to cylindrical ("barrel-cactus"); ovary scales ovate orbicular; fruit not woolly.

Central spine I; flowers purple.

I. E. Emoryi. 
Central spines 4; flowers greenish-yellow.

Radial spines all stout and annulated.

2. E. cylindraceus.

Radial spines of 2 kinds; the lateral slender and flexuous, the dorsal and ventral slightly ribbed.

3. E. Lecontei.

Stems numerous, often growing in mats; ovary-scales subulate; fruit densely woolly.

4. E. polycephalus.

I. Echinocactus Emoryi Engelm. in Emory, Notes Mil. Reconnois. 157. 1848.

Type locality: "Oct. 25, I846." According to Emory's notes he was on the Gila River in the vicinity of San Carlos Creek on this date.

Distribution: Central and western Arizona, southward into Sonora and Lower California, and westward into southern California. This species was reported from the "Mohave region" in the Botany of California, but it is not certain that Bigelow's specimens were collected on the California side of the Colorado River. The species is to be expected, however, along the eastern border of the Mohave Desert and southward along the eastern borders of the State. Lower Sonoran.

2. Echinocactus cylindraceus Engelm. Pacif. R. Rep. 4: 32. I 856 .

Echinocactus viridescens cylindraceus Engelm. Am. Journ. Sci. II. 14: 338 . I852.

Type locality: "Near San Felipe, on the eastern slope of the California mountains."

Distribution: Gravelly slopes and washes along the western border of the Colorado Desert. Lower Sonoran.

Specimens examined: Whitewater, Rose, 1908.

3. Echinocactus Lecontei Engelm. Pac. R. Rep. 4: $29 . \quad$ i 856. Echinocactus Wislizeni Lecontei Engelm. U. S. Geog. Surv. 6: I28. I 878.

Type locality: "First noticed by Dr. John L. LeConte, on the lower Gila."

Distribution: Southwestern Utah, westward to the eastern borders of southern California, and southward through western Arizona to Sonora. This species was observed by Bigelow "at the head waters of Williams River, down this stream to the Colorado, and west of it till $E$. polycephalus took its place." Coville 
and Funston also report it from Surprise Canyon, in the Panamint Mountains. Lower Sonoran.

4. Echinocactus polycephalus Engelm. Pac. R. Rep. 4: $3 \mathrm{I}$. 1856.

Type locality: "Stoney and gravelly hills and dry beds of torrents from 20 miles west of the Rio Colorado to about I 50 miles westward up the Mohave."

Distribution: From the vicinity of Victor, northward to the Inyo Mountains, and eastward to southwestern Utah and western Arizona. Lower Sonoran.

Specimens examined: Barstow, Rose, 1908.

\section{Carnegiea. Giant Cactus.}

I. Carnegiea gigantea (Engelm.) Britton \& Rose, Journ. N. Y. Bot. Gard. 9: 187. I908.

Cereus giganteus Engelm. in Emory, Notes Mil. Reconnois. I59. I848.

Pilocereus Engelmannii Lem. Ill. Hortic. 9: Misc. 97. 1862. Pilocereus giganteus Haage \& Schmidt, Cat. 230. 1898.

Type locality: "Along the Gila River, about the middle of its course."

Distribution: The Giant cactus occurs through the southern part of Arizona and northern Sonora, and, according to Dr. D. T. MacDougal, it extends across the Colorado River into the borders of southern California in the vicinity of Ehrenburg. Lower Sonoran.

\section{BERGEROCACTUS.}

I. Bergerocactus Emoryi (Engelm.) Britton \& Rose, Contr.

Nat. Herb. 12: 474. 1909.

Cereus Emoryi Engelm. Am. Jour. Sci. II. 14: 338. 1852.

Type locality: "In thick patches, on dry hills near the sea shore about the boundary line," near San Diego, California.

Distribution: Vicinity of San Diego, southward into Lower California. Lower Sonoran.

Specimens examined: Tia Juana, Abrams 3473. 
CORnACEAE. Dogwood Family.

Flowers in aments, dioecious; stigmas lateral.

Flowers not in aments, perfect; stigmas terminal.

Flowers cymose, not subtended by an involucre.

1. Garrya.

Flowers capitate, subtended by a large petaloid involucre.

2. Svida.

3. Cynoxylon.

\section{GARRYA. Sillk-tassel tree.}

Pubescence on lower surface of leaves of tangled or matted hairs.

I. G. Veatchii Palmeri.

Pubescence on lower surface of leaves of upwardly appressed hairs.

2. G. pallida.

I. Garrya Veatchin Palmeri (S. Wats.) Eastwood, Bot.

Gaz. 36: $45^{8}$. 1903 .

Garrya flavescens Palmeri S. Wats. Bot. Gaz. 1: 276. 1876.

Garrya Veatchii undulata Eastwood, Bot. Gaz. 36: 458 . I903.

Type locality: "Milquatay, 60 miles from San Diego, on the Fort Yuma Road."

Distribution: In the chaparral belt of the mountains from Ventura County south to northern Lower California. Upper Sonoran.

Specimens examined: La Cumbre trail, Santa Ynez Mountains, Abrams 4308; Switzer's trail, San Gabriel Mountains, Grinnell I6; Arroyo Seco Caynon, San Gabriel Mountains, Grinnell 40; Sisar Canyon, Topatopa Mountains, Abrams E McGregor 64; Lytle Creek Canyon, Abrams 2805; Lone Pine Canyon, San Gabriel Mountains, Abrams E McGregor $67 I$.

2. Garrya pallida Eastwood, Proc. Calif. Acad. III. 2: 287. 1902.

Type locality: "Kings River Canyon," Kern County, California.

Distribution: Southern Sierra Nevada south to the Cuiamaca Mountains. Upper Sonoran and lower altitudes of the Transition.

Specimens examined: Buckhorn Tavern, near Fort Tejon, Abrams E̋ McGregor 283; La Cumbre Peak, Santa Ynez Mountains, Abrams 4318; Topatopa Mountains, Abrams छ McGregor I04; Rock Creek, Abrams \& McGregor 568; Cold Creek, San Bernardino Mountains, Abrams \& McGregor 8I4; Mount Santiago, Abrams I8II; Middle Peak, Cuiamaca Mountains, Abrams 3872. 
2. SVIDA. Dogwood.

\section{Svida californica (C. A. Mey.)}

Cornus californica C. A. Mey. Bull. Phys.-Math. Acad. Petersb. 3: 372 . 1845 .

Cornus sericea occidentalis Torr. \& Gray, Fl. N. Am. 1: 652. 1840.

Cornus pubescens californica Coulter \& Evans, Bot. Gaz. 15: 37. 1890.

Cornus occidentalis Coville, Cont. Nat. Herb. 4: I17. 1893.

Type locality: "Hab. in litore occidentali Americae septentrionalis (Hooker), in California prope St. Francisco! (Cham.) et prope coloniam Ross!"

Distribution: Southern British Columbia and western Idaho, south to southern California. Upper Sonoran and Transition.

Specimens examined: Oak Knoll, Pasadena, Grant 217; Swartout Canyon, San Gabriel Mountains, Abrams E McGregor 653; near Strawberry Peak, San Bernardino Mountains, altitude I 800 meters, Abrams 2009; western slope of San Jacinto Mountain, altitude 1800 meters, Hall 2233; Cuiamaca Mountains, Palmer 46; Palomar Mountain, Parish 4465; Grass Valley, San Bernardino Mountains, Parish 3105.

\section{CYNOXYLON. Flowering Dogwood.}

I. Cynoxylon Nuttallin (Audubon) Shafer, in Britton, N. Am. Trees 746. 1908.

Cornus Nuttallii Audubon; Torr. \& Gray, Fl. N. Am. 1: 652. I 840 .

Type locality: "Oregon."

Distribution: British Columbia and northern Idaho, extending southward to the mountains of southern California. Transition.

Specimens examined: Near Strawberry Peak, San Bernardino Mountains, altitude I 800 meters, Abrams 2016.

\section{ERICACEAE. Heath Family.}

Fruit capsular; anthers not appendaged.

Bracts thin, deciduous; leaf-buds scaly; leaves not heath-like.

I. Azalea.

Bracts firm, persistent; no scaly buds; leaves heath-like.

2. Phyllodoce. 


\section{$(430)$}

Fruit a berry or berry-like drupe; anthers with dorsal, reflexed appendages; corolla urn-shaped.

Ovary 5-celled; ovules several to each cell.

Ovary 5-10 celled; ovules I to each cell.

Ovary rugose or granular.

Ovary not rugose or granular.

3. Arbutus.

4. Comarostaphylis.

Leaves dark green and glabrous above, tomentose beneath, not vertical.

5. Xylococcus.

Leaves similar on both surfaces, often vertical.

6. Uva-ursi.

\section{AZALEA. Azalea.}

I. Azalea occidentalis Torr. \& Gray, Pacif. R. Rep. 4: ir6. I857.

Rhododendron occidentale A. Gray, Bot. Calif. 1: 458. I876.

Type locality: "Laguna de Santa Rosa, in low and wet ravines."

Distribution: Coast Ranges and Sierra Nevada, southward to the Cuiamaca Mountains in San Diego County. Transition.

Specimens examined: San Jacinto Mountains, in canyons on the west side, at 1800 meters, Hall 224I; Cuiamaca Mountains, altitude 1500 meters, Susan G. Stokes, July, 1895; Abrams 3953.

\section{PHYLLODOCE.}

I. Phyllodoce Breweri (A. Gray) Heller, Muhlenbergia 1: I. 1900.

Bryanthus Breweri A. Gray, Proc. Am. Acad. 7: 367. 1868.

Type locality: Of the several specimens cited, the first, which was collected by Brewer, was from "Woods Peak, Eldorado Co.," California.

Distribution: Southern Cascade Mountains, southward through the higher altitudes of the Sierra Nevada to Mount San Gorgonio, San Bernardino Mountains. Canadian Zone.

Specimens examined: Mount San Gorgonio, Abrams \& $M c-$ Gregor 750.

\section{ARBUTUS. MAdRoÑo.}

I. Arbutus Menziesir Pursh, Fl. Am. Sept. 1: 282. I8I4.

Type locality: "On the north-west coast of America."

Distribution: British Columbia, southward to the San Gabriel Mountains in southern California. Transition and extending into the Upper Sonoran. 
Specimens examined: Mt. Wilson trail, altitude rooo meters, Abrams I5I5.

\section{COMAROSTAPHYLIS.}

I. Comarostaphylis diversifolia (Parry) Greene, Bull. Calif. Acad. 2: 406. I 887 .

Arctostaphylos arguta diversifolia Parry, Proc. Davenp. Acad. 4:

35. 1884 .

Arctostaphylos diversifolia Parry; A. Gray, Syn. F1. 2, ed. 2, pt. I:

397. 1886.

Type locality: "In Jamul Valley." The first of several localities mentioned, and the only one from which flowering specimens were obtained.

Distribution: Santa Monica Mountains, southward to northern Lower California, and on the islands off the coast, as far northward as Santa Cruz Island. Upper and Lower Sonoran.

Specimens examined: Santa Cruz Island, Grinnell, Sept. 3, I903; Topango Canyon, Santa Monica Mountains, Hasse, July I4, 1906.

\section{XYLOCOCCUS.}

I. XYlococcus bicolor Nutt. Trans. Am. Phil. Soc. II. 8: 259. 1843 .

Comarostaphylis bicolor Klotzsch, Linnaea 24: 78. 1851 . Arctostaphylos bicolor A. Gray, Proc. Am. Acad. 7: $366 . \quad$ I867. Arctostaphylos Clevelandi A. Gray, Syn. Fl. 2, pt. I: 29. 1878. Type locality: "Hab. Monterey, Upper California." This is probably an error for the species is not known in the Monterey region. Nuttall's specimens no doubt came from San Diego.

Distribution: In the chaparral on the mesas and foothills of western San Diego County, southward to northern Lower California, also on the islands off the coast. Upper and Lower Sonoran.

Specimens examined: Cottonwood Grade, near Potrero, Abrams 3729.

\section{UVA-URSi. Manzanita or Bearberry.}

Pedicels and ovaries glabrous.

Stone solid, broadly ellipsoid, merely angled or ribbed; branchlets, inflorescence and young leaves canescent.

1. U. Parryana.

Stone lobed, depressed-globose, irregularly separable into nutlets.

Branchlets, inflorescence and young leaves canescent; leaves becoming dull-green.

2. U. pungens. 
Branchlets and inflorescence with a golden resinous undument, or glandular pubescent; leaves bright yellowish-green.

$$
\text { 3. U. patula. }
$$

Pedicels more or less pubescent or villous; ovaries pubescent or viscid.

Bracts firm, herbaceous or foliaceous; sepals ciliate on the margins, otherwise glabrous or puberulent.

Fruit ovoid, very viscid; stone solid, slightly ribbed; leaves very glaucous; branchlets glabrous or sometimes glandular-villous.

4. U. glauca.

Fruit depressed-globose, pubescent, not viscid; stone lobed and separable into irregular nutlets; pubescence of herbage variable.

5. U. tomentosa.

Bracts thin and scarious; sepals and herbage glandular-villous; stone solid, ovoid.

6. U. drupacea.

Dr. F. N. Williams (Journ. Bot. 48: 183, I84. I910) has shown that Uva-ursi (Tourn.) Miller (Gard. Dict. 3. 1754) has priority over Arctostaphylos Adans. (Fam. 2: 163. 1763) and should replace it, according to the Vienna Rules.

\section{Uva-ursi Parryana (Lemmon)}

Arctostaphylos Parryana Lemmon, Pittonia 2: 68. I 890.

Type locality: "On the Tehachapi Mountains of south-central California, four miles west of Keene Station."

Distribution: Tehachapi Mountains and Mount Pinos, southward to Mount San Antonio. Transition and Upper Sonoran.

Specimens examined: Mount Pinos, altitude 2100 meters, Abrams E' McGregor 26I; Elmer 3980; Soldiers' Camp, near Fort Tejon, Abrams Eं McGregor 28I; Coldwater Canyon, Mount San Antonio, altitude 2250 meters, Abrams 2716.

\section{Uva-ursi pungens (H.B.K.).}

Arctostaphylos pungens H.B.K. Nov. Gen. \& Sp. 3: 278, pl. 259. I8I8.

Daphnidostaphylos pungens Klotzsch, Linnaea 24: 80. I851.

Type locality: "Crescit in Regio Mexicano, locis alsis, juxta Moran et Villalpando, alt. I300-I400 hex."

Distribution: Southern California, southward to the mountains of Lower California and central Mexico. Upper Sonoran.

Specimens examined: Near Clark's ranch, San Bernardino Mountains, altitude 1500 meters, Abrams 2936; between Campo and Jacumba Hot Spring, Abrams 3624; Pine Valley, San Diego 
County, Mearns 3980; West Fork of Deep Creek, San Bernardino Mountains, Abrams Eं McGregor $72 I$.

\section{Uva-ursi patula (Greene)}

Arctostaphylos patula Greene, Pittonia 2: I7I. I89r.

Type locality: "The common manzanita of dry rocky ridges in pine woods of middle altitudes in the Sierra Nevada, California, from Calaveras Co. southward to Fresno."

Distribution: Southern Cascade Mountains, southward to the San Jacinto Mountains. Transition.

Specimens examined: Strawberry Peak, San Bernardino Mountains, Abrams 2019; Tahquitz Valley, San Jacinto Mountains, altitude 2400 meters, Hall 2419 (in part); between Dollar Lake and Hathaway Flat, San Bernardino Mountains, Abrams \& McGregor 804 .

\section{Uva-ursi glauca (Lindl.)}

Arctostaphylos glauca Lindl. Bot. Reg. 21: sub pl. I79I. I836.

Type locality: "California, Douglas."

Distribution: Central California, southward to the southern boundary of the State. Upper Sonoran.

Specimens examined: Santa Ynez Mountains, Elmer 3967; Arroyo Seco Canyon, San Gabriel Mountains, Grinnell 32, 37; Mount Wilson trail, altitude 900 meters, Abrams I50I; Red Reef Canyon, Topatopa Mountains, Abrams \& McGregor 156; Lone Pine Canyon, San Gabriel Mountains, Abrams \& McGregor 670.

\section{Uva-ursi tomentosa (Pursh)}

Arbutus tomentosa Pursh, Fl. Am. Sept. 1: 282. I8I4. Arctostaphylos tomentosa Dougl. Bot. Reg. 21: pl. $79 I I . \quad 1836$. Xerobotrys tomentosus Nutt. Trans. Am. Phil. Soc. II. 8: 268. 1843 .

Type locality: "On the north-west coast of America."

Distribution: Southern British Columbia, southward to northern Lower California. In southern California this species grows in the higher altitudes of the Upper Sonoran and sometimes extends into the lower part of the Transition. There is great variation, especially in pubescence, and several well-marked forms seem to occupy distinct geographic areas. In the coastal mountains the 
plants are usually setose-hispid and glandular-pubescent or glandular-villous. They are very much like Menzies' original specimens, and perhaps are also identical with $A$. glandulosa Eastw. The specimens I have cited from the Topatopa, the Liebre, and the San Bernardino Mountains are not at all glandular and are almost or entirely without setose hairs. The leaves are comparatively bright green, being only sparsely tomentose. In the Cuiamaca Mountains, on the other hand, the plants have very pale foliage, which is more or less permanently canescent. The branches are without setose hairs, but are either canescent or glandularpubescent.

Specimens examined: Santa Ynez Mountains, Elmer 3798; Mount Wilson trail, altitude 600 meters, Abrams I500; Topatopa Mountains, Abrams छै McGregor 84; Liebre Mountain, Abrams छซ McGregor 370; Cleghorn Canyon, San Bernardino Mountains, Abrams 83 McGregor 705; Mount Wilson trail, altitude 1000 meters, Abrams I520; Los Tunas Canyon, Santa Monica Mountains, Abrams 1699; Silverado Canyon, Santa Ana Mountains, Helen D. Geis 723; between Julian and Banner, Abrams 3973; hills near Campo, Abrams 3620 .

\section{Uva-ursi drupacea (Parry)}

Arctostaphylos Pringlei drupacea Parry, Bull. Calif. Acad. 2: 494. 1887.

Type locality: "Mountains east of San Diego."

Distribution: San Bernardino Mountains, southward to northern Lower California. Transition.

Specimens examined: Mill Creek Falls, I600 meters, Parish 5070; Strawberry Peak, San Bernardino Mountains, Abrams, July 28, 190I; Abrams छ McGregor 726; San Jacinto Mountains, altitude I 400 meters, Hall 2092; summit of Cuiamaca Mountain, Abrams 3947; Cold Creek, San Bernardino Mountains, Abrams छ McGregor 815.

STYRACACEAE. Styrax Family.

I. STYRAX. Storax.

I. Styrax californicum fulvescens Eastw. Bot.

Gaz. 41: 286. 1906.

Type locality: "Near the Painted cave in the Santa Ynez Mountains back of Santa Barbara, California." 
Distribution: Santa Ynez Mountains and San Bernardino Mountains, in the upper portion of the chaparral belt. Upper Sonoran.

Specimens examined: Near Santa Barbara, Bolander, I873; Santa Ynez Mountains, Brandegee, r888; foothills of the San Bernardino Mountains, Clare E. Cummings, May I, I896; foothills near San Bernardino, altitude 1800 meters, Wright 2I6; San Bernardino Mountains, altitude 800 meters, Leiberg 3324; Vasey 361; Waterman Canyon, Shaw E๐ Illingsworth I4.

\section{OLEACEAE. Olive Family.}

Fruit a samara; leaves usually pinnate.

I. Fraxinus.

Fruit not a samara; leaves entire.

Fruit a 2-parted membranous capsule; corolla yellow; low shrub.

Fruit a drupe; corolla none; arborescent shrub.

2. Menodora.

3. Adelia.

Leaflets several.

\section{FRAXINUS, AsH.}

Petals 2; leaflets rounded or obtuse at apex, $2-3 \mathrm{~cm}$. long.

Petals none; leaflets acute or acuminate.

I. F. dipetala.

Body of the fruit equaling the wing in length; lateral leaflets sessile.

2. F. oregona.

Body of the fruit scarcely over half the length of the wing.

Leaves usually glabrous; lateral leaflets stalked. 3. F. coriacea.

Leaves tomentose-pubescent; lateral leaflets sessile.

Leaflets only 1 or occasionally 3 .

4. F. velutina.

5. F. anomala.

I. Fraxinus dipetala Hook. \& Arn. Bot. Beech. 362, pl. 87. I 840 .

Type locality: California, Douglas.

Distribution: Coast Ranges and foothills of the Sierra Nevada, south to southern California, where it is most frequent in the interior mountains. Upper Sonoran.

Specimen sexamined: Santa Ynez Mountains, Elmer 3822; Mill Creek, San Bernardino Mountains, Parish 5053; Abrams E' McGregor 82I; Sespe Creek, near Ten Sycamore Flat, Abrams E McGregor I75; Sulphur Mountain, Abrams E McGregor 37; Potrero Hills, near San Jacinto, S. B. छ W. F. Parish 278; City Creek Canyon, San Bernardino Mountains, altitude 600 meters, Leiberg 3301 . 
2. Fraxinus oregona Nutt. Sylva N. Am. 3: 59 . 1849. Fraxinus americana oregona Wesmael, Bull. Soc. Bot. Belg. 30: IIO. I 892 .

Type locality: "This is the only species of Ash we met with in the Oregon territory. ... We never saw it above the falls of the Oregon."

Distribution: Puget Sound, southward through western Washington and Oregon to southern California. Upper Sonoran and Transition.

Specimens examined: San Gabriel River Canyon, Abrams 876 .

3. Fraxinus coriacea S. Wats. Am. Nat. 7: 30. 1873.

Type locality: "Ash Meadows, Nevada, and Devil's Run Canyon, Arizona."

Distribution: Southern Utah and Nevada to northern Arizona, and from the vicinity of Owen's Lake southward in the San Gabriel and San Bernardino Mountains, California. Upper Sonoran.

Specimens examined: Lytle Creek Canyon, altitude 800 meters, Abrams 274I; Liebre Mountains, Abrams Eे McGregor 400; Cajon Pass, Abrams Eं McGregor 692; Cleghorn Canyon, San Bernardino Mountains, Abrams \& McGregor 703. (These specimens have narrower leaflets and much broader samaras than typical coriacea, and, on more extensive examination of material, may prove to be distinct.)

4. Fraxinus velutina Torr. in Emory, Notes Mil. Reconnois. I49. 1848 .

Type locality: "In the region between the waters of the Del Norte and Gila; also on the Mimbres, a tributary of the latter river."

Distribution: Southern New Mexico and Arizona to southern California. Upper Sonoran.

Specimens examined: Between Campo and Jacumba Hot Spring, Abrams 3705; near Toro Mountain, altitude 1300 meters, Leiberg 3167.

5. Fraxinus amomala Torr.; S. Wats. Bot. King's Exped. 283. I874.

Type locality: "In Labyrinth Canyon on the Colorado River, Utah," and "St. George on the Rio Virgen in the southwestern portion of the State." 
Distribution: Southwestern Colorado, southern Utah and Nevada, southward to northern Arizona, and the Providence Mountains in southern California. Upper Sonoran.

Specimens examined: Providence Mountains, Brandegee, 1902.

\section{MENODORA.}

Shrubby, 6-Io dm. high, spinescent; herbage puberulent; corolla-lobes oblong, $3 \mathrm{~mm}$. long.

I. M. spinescens.

Woody only at base, $3-4 \mathrm{dm}$. high, not spinescent; herbage glabrous; corollalobes ovate, $6-8 \mathrm{~mm}$. long.

2. M. scoparia.

I. Menodora spinescens A. Gray, Proc. Am. Acad. 7: 388. I867.

Type locality: "Canyons and hillsides of the southwestern part of the State of Nevada."

Distribution: Southern Nevada westward to Inyo County, California, and southward to the Providence Mountains. Lower Sonoran.

Specimens examined: Providence Mountains, Cooper, May 29, I86I.

2. Menodora scoparia Engelm.; A. Gray, Bot. Calif. 1: 47 I. I876.

Menodora scabra glabrescens A. Gray, U. S. Geog. Surv. 6: I 5 . 1878.

Type locality: "Saltillo, Mexico."

Distribution: Northern Mexico and western Texas westward to the desert slopes of the southern California mountains. Lower Sonoran.

Specimens examined: Dry gravelly hills, Jacumba Hot Spring, Abrams $364 I$.

\section{ADELIA.}

I. Adelia neo-mexicana (A. Gray) Kuntze, Rev. Gen. Pl. 2: 4 Io. I89I.

Forestiera neo-mexicana A. Gray, Proc. Am. Acad. 12: 63. 1876. Forestiera acuminata parvifolia A. Gray, Proc. Am. Acad. 4: 364. 1859.

Adelia parvifolia Coville, Contr. Nat. Herb. 4: I48. 1893. 
Type locality: "New Mexico; near Santa Fe, Fendler, no. 547. Below El Paso, Wright, no. 1699. Semelenque Springs, Dr. Bigelow."

Distribution: Western Texas and southern Colorado westward to the western extremities of the Mohave Desert in southern California. Upper and Lower Sonoran.

Specimens examined: Willow Springs, Antelope Valley, Abrams छ' McGregor 425; Rock Creek, east slope of the San Gabriel Mountains, altitude 1350 meters, Abrams Eे McGregor 566.

\section{POLEMONIACEAE. Phlox Family.}

\section{LEPTODACTYLON.}

Corolla salverform, $2.5-3 \mathrm{~cm}$. long.

Herbage not glandular-pubescent.

Herbage glandular-pubescent.

Corolla funnelform, $1.5^{-2} \mathrm{~cm}$. long.

I. L. californicum.

Ia. L. californicum glandulosum.

Herbage glandular-pubescent; leaves alternate.

2. L. Hookeri.

Herbage not glandular-pubescent; leaves opposite.

3. L. Hallii.

I. Leptodactylon californicum Hook. \& Arn. Bot. Beech. 369. 1840.

Gilia californica Benth. in DC. Prod. 9: 3 I6. 1845.

Type locality: California. Collected by Douglas probably near Monterey or Santa Barbara.

Distribution: In chaparral of the coast mountains from Santa Barbara northward to Monterey. Upper Sonoran.

Specimens examined: Santa Barbara, Brandegee, no date.

\section{Ia. Leptodactylon californicum glandulosum (Eastw.).}

Gilia californica glandulosa Eastw. Bot. Gaz. 37: 447. 1904.

Type locality: "The common form growing around Pasadena, California."

Distribution: In the chaparral belt of the mountains of southern California. Upper Sonoran.

Specimens examined: Near Pasadena, Jones 3209; La Canada, Forbes, May 2, 1902; Little Santa Anita Canyon, San Gabriel Mountains, Abrams 2624; Santa Ana Canyon, near Yorba, Helen D. Geis, April, 1902; Lytle Creek Canyon, altitude 600 meters, Hall I4I3. 


\section{(439)}

2. Leptodactylon Hookeri (Dougl.) Nutt. Journ. Acad. Philad. II. 1: 157 . I 847 .

Phlox Hookeri Dougl.; Hook. Fl. Bor. Am. 2: 73. pl. $559 . \quad$ I838. Gilia Hookeri Benth. in DC. Prod. 9: 316.1845.

Gilia pungens Hookeri A. Gray, Proc. Am. Acad. 8: 268. I870. Gilia pungens eupungens var. Hookeri Brand. Pflanzenreich 4, Fam. 250: 126. I907.

Type locality: "Hab. common on arid, sandy and rocky soils near the narrows of the Oakangen and Priest's Rapids of the Columbia."

Distribution: Southern British Columbia, southward through Washington and Oregon to southern California. Transition.

Specimens examined: Mount Pinos, Elmer 3744; near Green Valley, San Bernardino Mountains, Hall I064; Bear Valley, Parish 3683; Snow Canyon, San Bernardino Mountains, Parish 5050 .

3. Leptodactylon Halli (Parish) Heller, Muhlenbergia 1: 146. I906.

Gilia Hallii Parish, Erythea 7: 94. I 899.

Gilia pungens Hallii Milliken, Univ. Calif. Pub. Bot. 2: 42. I904.

Type locality: "Coyote Canyon, at 5,000 ft. alt. on the desert slope of El Toro Mt."

Distribution: Known only from the region of the type locality. Transition.

Specimens examined: Coyote Canyon, Santa Rosa Mountains, Hall 2130 .

\section{HYDROPHYLLACEAE. Water-leaf Family.}

\section{ERIODICTYON. YERBa santa.}

Herbage aromatic, not glandular-pubescent.

Leaves glutinous, nearly or quite glabrous at least above.

I. E. trichocalyx.

Leaves not glutinous, more or less densely silky-tomentose on both surfaces.

Corolla 8-12 mm. long, much exceeding the calyz.

Corolla 2-3 $\mathrm{mm}$. long, scarcely exceeding the calyx.

2. E. crassifolium.

3. E. Traskiae.

Herbage very heavy-scented, glandular-pubescent throughout, not at all tomentose.

4. E. Parryi. 
r. Eriodictyon trichocalyx Heller, Muhlenbergia 1: io8. I904.

Eriodictyon glutinosum pubens A. Gray, Proc. Am. Acad. 17: 224. I 882.

Type locality: "Seven Oaks Camp, San Bernardino Mountains."

Distribution: Southern California from the San Gabriel Mountains south to the Mexican Boundary. Upper Sonoran.

Specimens examined: Mount Wilson, in chaparral near the summit, Abrams 2607; mesas near San Bernardino, S. B. छ W. F. Parish 4II; Mount San Antonio, altitude 1800 meters, Abrams 2685; Edgar Canyon, San Bernardino Mountains, Parish 2977; in chaparral between Campo and Jacumba Hot Spring, Abrams 3632; Mount Wilson, Davidson, June 12, I892; Rock Creek, altitude II 40 meters, Abrams \& McGregor 526.

2. Eriodictyon crassifolium Benth. Bot. Sulph. 35. I844.

Eriodictyon tomentosum Benth. Bot. Sulph. 36. 1844 .

Type locality: "San Diego."

Distribution: In the chaparral of the foothills and mountains from Santa Barbara County southward to northern Lower California. Upper and Lower Sonoran. The form occurring in the Lower Sonoran, especially in Riverside and San Diego Counties, is much more silky-tomentose than the more northern Upper Sonoran form.

Specimens examined: Santa Ynez Mountains, near Santa Barbara, Brandegee, 1888; Laurel Canyon, Santa Monica Mountains, Hasse, July, 1890; Glendora, Braunton 293; San Fernando Mountains near Chatsworth, Abrams 1363; Acton, Elmer 3598; Little Santa Anita Canyon, Abrams 2627; Newhall, Davidson, May 5, I890; Fort Tejon, Abrams \& McGregor 300; Sisar Canyon, Topatopa Mountains, Abrams छ McGregor 65; Red Reef Canyon, Topatopa Mountains, Abrams \& McGregor 142, 159; Oakgrove Canyon, Liebre Mountains, Abrams $\& 3$ McGregor 322; near Orange, Agnes M. Bowman, June, I899; western base of San Jacinto Mountains, Hall 2006; San Jacinto, Berg, April 3, 1904; Witch Creek, Alderson, May, I894; Mission Hills, near San Diego, Abrams 3432; Chollas Valley, Susan G. Stokes, June, I895; San Diego, Brandegee, I889; Point Loma, Chandler 5067. 
3. Eriodictyon Traskiae Eastwood, Proc. Calif. Acad. III. 1: I2I. I 898 .

Type locality: "On one volcanic upland on Santa Catalina Island, Calif., at an elevation of about 1500 feet."

Distribution: Santa Ynez Mountains on the mainland, and Santa Catalina Island. Upper Sonoran.

Specimens examined: Santa Ynez Mountains, Elmer 40I7; the Sisquoc, Santa Barbara County, Baker, July, I895.

4. Eriodictyon Parryi (A. Gray) Greene, Pittonia 2: $22 . \quad$ is89. Nama Parryi A. Gray, Bot. Calif. 1: 621. 1876.

Type locality: "On the Mohave slope of the San Bernardino Mountains."

Distribution: San Gabriel Mountains southward to the Cuiamaca Mountains, and probably extending into northern Lower California. Transition.

This is an anomalous species, strikingly different in habit; the tall, mostly simple, herbaceous stems arise from a more or less woody, branching base.

Specimens examined: Mount Gleason, San Gabriel Mountains, Elmer 3643; open pine forests in the vicinity of Strawberry Valley, San Jacinto Mountains, Hall 2502; between Cuiamaca and Oriflamme Canyon, Cuiamaca Mountains, Abrams 3027; Rock Creek, altitude 1650 meters, Abrams E $\sigma^{\circ}$ cGregor 577; Oakgrove Canyon, Liebre Mountains, Abrams \& McGregor 386.

\section{MENTHACEAE. Mint Family.}

Anther-bearing stamens 4 .

Ovary merely 4-lobed; stamens coiled in the bud, becoming long-exserted in flower.

I. Trichostema.

Ovary deeply 4-parted; stamens not long-exserted.

Calyx becoming much inflated.

Calyx not inflated.

Anther-bearing stamens 2.

2. Salazaria.

3. Sphacele.

4. Ramona.

\section{r. TRichostemA. Blue-CURl.}

Corolla-tube well-exserted beyond the calyx.

I. T. lanatum.

Corolla-tube scarcely exserted beyond the calyx.

2. T. Parishii

I. Trichostema lanatum Benth. Lab. Gen. \& Sp. 659. 1835.

Type locality: "Hab. in California." First collected by Douglas. Distribution: On dry chaparral ridges from Monterey County 
southward to Orange County. In southern California this species is confined to the mountains toward the coast from the Santa Ana Mountains northward. Upper Sonoran.

Specimens examined: Sierra Madre, Nevin 932; near Los Angeles, Wallace; Santa Monica Mountains, Abrams 1267; Santiago Canyon, Santa Ana Mountains, Helen D. Geis, May, I902; Silverado Canyon, Santa Ana Mountains, Helen D. Geis 720 (a form with white instead of purple wool).

2. Trichostema Parishil Vasey, Bot. Gaz. 6: I73. I880.

Trichostema lanatum denudatum A. Gray, Syn. Fl. 2, pt. I: 459. I886.

Type locality: "San Diego Co., Cal."

Distribution: On dry ridges of the more interior foothills and mountains of southern California, where it replaces the coastal and more northern T. lanatum. Upper.Sonoran.

Specimens examined: Southern California, no locality given, Vasey $छ 3$ Parish, I880; vicinity of San Bernardino, Parish 3645; Potrero, Susan G. Stokes, July, I895; San Antonio Mountains, altitude 900 meters, Hall 1482; Lone Pine Canyon, San Gabriel Mountains, Abrams E McGregor 666; Acton, Elmer 3698; Jacumba Hot Spring, Mearns 3352; between Jacumba Hot Spring and Campo, Abrams 3692.

\section{SALAZARIA.}

I. Salazarta mexicana Torr. Bot. Mex. Bound. 133. I859.

Type locality: "Ravines, Chihuahua, below Presidio del Norte near the Rio Grande."

Distribution: Dry washes of the arid region, from the Mohave Desert of southern California eastward to southern Utah, and southward to northern Mexico. Lower Sonoran.

Specimens examined: Mill Creek Canyon, Panamint Mountains, Coville E F unston 756; southern slope of Tehachapi Pass, Brandegee, July, 1884; Abrams छ McGregor 494; Mohave Desert, S. B. छ W. F. Parish 893; Mohave Desert, near Hesperia, Parish 4932; eastern base of the San Jacinto Mountains, along the borders of the Colorado Desert, Hall 2107. 
3. SPhacele. Pitcher sage.

I. Sphacele fragrans Greene, Pittonia 1: 38.1887.

Sphacele calycina Wallacei A. Gray, Syn. Fl. 2, pt. I: 365. 1878.

Type locality: "In canyons of the south side of Santa Cruz Island."

Distribution: On shady slopes in the foothills and mountains of the islands and on the mainland in the San Gabriel Mountains. Upper Sonoran.

Specimens examined: Santa Cruz Island, Brandegee, April, I888; southern California, probably Santa Catalina Island, $W$ allace; Santa Catalina Island, McClatchie, Sept. I2, IS93; near Claremont, Baker 506r; Switzer's trail, San Gabriel Mountains, Davidson, June I2, I893.

\section{RAMONA.}

Bracts scarious-membranous.

Leaves entire, not at all rugose.

Inflorescence villous; bracts less than $10 \mathrm{~mm}$. long.

$\begin{array}{ll}\text { Inflorescence puberulent; bracts } I 5 \mathrm{~mm} \text {. long. } & \text { I. } R \text {. pilosa. } \\ \text { ves crenulate, rugose. } & \text { 3. } R \text {. capitata. }\end{array}$

Leaves crenulate, rugose.

Bracts herbaceous; leaves crenate, rugose.

Stems woody at base, scape-like, about $2 \mathrm{dm}$. high. 4. R. humilis.

Shrubs, I-2 m. high.

Inflorescence verticillate-glomerate and interrupted-spicate; corrollatube longer than the limb.

Corolla about I cm. long.

Bracts cuspidate-acuminate, somewhat tomentose.

Bracts obtuse, hoary-tomentose.

5. R. stachyoides.

6. R. nivea.

Corolla $2 \mathrm{~cm}$. long.

Bracts acute or acute-cuspidate.

Bracts conspicuously aristate.

7. R. Clevelandi.

8. R. Vaseyi.

Inflorescence thyrsoid-paniculate; corolla-tube shorter than the limb.

9. R. polystachya.

\section{Ramona pilosa (A. Gray).}

Audibertia incana pilosa A. Gray, Syn. Fl. 2, ed. 2, pt. x: 46 r. I886.

Type locality: "Northern base of San Bernardino Mountains, on the border of the Mohave Desert."

Distribution: Mohave Desert, chiefly in the juniper and yucca belts. Lower Sonoran. 


\section{(444)}

Specimens examined: Northern base of the San Bernardino Mountains, Mohave Desert, S. B. E W. F. Parish 1309; Mohave Desert, about 1200 meters, Parish 3847; Acton, Hasse, May 21, I893; Mescal Creek, Antelope Valley, Hall 3026; Mohave Desert, near Burcham's ranch, Parish 4935; Rock Creek, Abrams है McGregor 547; Palmdale, Abrams है McGregor 523.

2. Ramona pachystachya (A. Gray) Heller, Muhlenbergia 1: 4 . I 900.

Audibertia incana pachystachya A. Gray, Syn. Fl. 2, ed. 2, pt. I : 46 I. I 886.

Audibertia pachystachya Parish, Erythea 6: 9I. 1898.

Salvia carnos a compacta Hall, Univ. Calif. Pub. Bot. 1: III. I902.

Type locality: "Bear Valley in the San Bernardino Mountains. Southern borders of San Diego Co."

Distribution: In the vicinity of Bear Valley, San Bernardino Mountains, and in the San Jacinto Mountains. Upper Sonoran and Transition.

Specimens examined: Eastern base of the San Jacinto Mountains, Hall 2160; Bear Valley, San Bernardino Mountains, Parry, I876; Parish 330; The Pines, Santa Ana Canyon, altitude I650 meters, Abrams है McGregor 523.

3. Ramona capitata (A. Gray) Briquet, Bull. Herb.

Boiss. 2: 440. I 894 .

Audibertia capitata A. Gray, Proc. Am. Acad. 7: 387. 1867.

Salvia mohavensis Greene, Pittonia 2: 235. 1892.

Type locality: "Summit of Providence Mountain, Mohave Desert."

Distribution: Known only from the type locality. Upper Sonoran.

4. Ramona humilis (Benth.) Greene, Erythea 1: 144. I893. Audibertia humilis Benth. Lab. Gen. \& Sp. 313. 1833.

Salvia sonomensis Greene, Pittonia 2: 236. 1892.

Type locality: "Hab. in California septentrionali."

Distribution: Coast Ranges and Sierra Nevada of northern and central California, also in the Cuiamaca Mountains. This is merely a low herbaceous plant with a woody caudex. Transition. 
Specimens examined: Cuiamaca Mountain, Brandegee, June 15 , I 894; between Cuiamaca Lake and Oriflamme Canyon, Abrams 3938 .

5. Ramona stachyoides (Benth.) Briquet, Bull. Herb. Boiss. 2: 440. I 894 .

Audibertia stachyoides Benth. Lab. Gen. \& Sp. 3I3. I833. Salvia mellifera Greene, Pittonia 2: $236 . \quad$ I 892.

Type locality: "In California septentrionali."

Distribution: Santa Cruz and Mount Hamilton ranges southward to northern Lower California. In southern California this is one of the common and characteristic shrubs of the dry plains and foothills. It is commonly called "black sage," and is highly prized by bee-keepers. Upper Sonoran.

Specimens examined: Montecito, Bingham 30; Mission Canyon, Santa Barbara, Abrams, March 6, r909; Sepulveda Canyon, Santa Monica Mountains, Abrams 2540; Pasadena, Mc Clatchie, May 20, 1897; near Orange, Miss Bowman, June, I899; plains near San Bernardino, Parish 4795; San Diego, Palmer zor; Dunn, March 21, I89I; Miss Susan G. Stokes, June, I895; Point Loma, Chandler 5063; Big Tejunga wash, San Fernando Valley, Abrants I39I; Ramona, Brandegee (distributed by C. F. Baker 3410 ).

\section{Ramona nivea (Benth.) Briquet, Bull. Herb. Boiss. 2: 440. 1894 .}

Audibertia nivea Benth. Lab. Gen. \& Sp. 313. 1833.

Salvia leucophylla Greene, Pittonia 2: 236. 1892.

Type locality: "In California septentrionali."

Distribution: A common shrub on the low foothills from Santa Barbara County south to the Santa Ana Mountains. Upper Sonoran.

Specimens examined: Near Ojai, Peckham, I866; Santa Barbara County, Rothrock 4, I33; Bolander, 1873; San Francisquito Canyon, Parish, June, I887; Newhall, Pringle, May 20, I882; A. Gray, May, 1885; Saugus, Grant II05; Sulphur Mountain, Abrams \& McGregor I3; Sespe Creek, near Ten Sycamore Flat, Abrams छ० McGregor I85. 
7. Ramona Clevelandi (A. Gray) Biqquet, Bull. Herb.

Boiss. 2: 440. 1894.

Audibertia Clevelandi A. Gray, Proc. Am. Acad. 10: $76 . \quad$ I874. Salvia Clevelandi Greene, Pittonia 2: $236 . \quad 1892$.

Audibertia Palmeri A. Gray, Bot. Calif. 1: 601. 1876.

Salvia Palmeri Greene, Pittonia 2: 236. 1892.

Ramona Palmeri Briquet, Bull. Herb. Boiss. 2: 440. 1834.

Type locality: "Mountains behind San Diego, California, at the elevation of about 2,200 feet."

Distribution: In the chaparral of western San Diego County and Santa Catalina Island, southward to northern Lower California. Upper Sonoran.

Specimens examined: Tigh's ranch, near Cuiamaca, Palmer 302; San Juan Capistrano, Nevin 686; Santa Catalina Island, Lyon I2; near Potrero, Abrams 3745; Descanso, Parish 4424; near Ramona, Abrams 3778; near Valley Centre, Chandler 5349.

8. Ramona Vaseyi (Porter) Briquet, Bull. Herb. Boiss. 2: 440. I894.

Audibertia Vaseyi Porter, Bot. Gaz. 6: 207. I88I.

Type locality: "Mountain Springs, San Diego County, California."

Distribution: Desert slopes of the mountains of southern California from Morongo Pass south to the Mexican Boundary. Lower Sonoran.

Specimens examined: Morongo wash, Parish 3233; Mountain Springs, Vasey, I880.

9. Ramona polystachya (Benth.) Greene, Pittonia 2: 235. I 892.

Audibertia polystachya Benth. Lab. Gen. \& Sp. 314. I833.

Type locality: "In California septentrionali."

Distribution: Monterey County southward to northern Lower California. This is a very common shrub on the low hills and dry plains of southern California, and is commonly called "white sage." Upper and Lower Sonoran.

Specimens examined: Mountain Drive, near Santa Barbara, Abrams 4125; Acton, Elmer 3684; Sierra Madre, Abrams 2642; Claremont, Baker 4155; San Bernardino, Parish 4796; Coronado, Chandler 5172; San Diegn, Thurber 530; Palmer 300; Miss Susan 
G. Stokes, July, I895; Red Reef Canyon, Topatopa Mountains, Abrams Eं McGregor 147; Rock Creek, altitude 1350 meters, Abrams है McGregor 560.

\section{SOlANACEAE. Nightshade Family.}

Corolla rotate; stamens connivent.

I. Solanum.

Corolla tubular or funnelform; stamens not connivent.

Fruit a berry, sometimes becoming nearly dry.

2. Lycium.

Fruit capsular.

3. Nicotiana.

\section{SOLANUM. Nightshade.}

Corolla 5-cleft; peduncles longer than the pedicels. I. S. Douglasii.

Corolla 5-toothed or 5-lobed; peduncles shorter than the pedicels.

Leaves entire; stems glabrate or viscid-pubescent.

Herbage viscid-pubescent.

Herbage glabrate or hispidulous.

Leaves crenate; stems long-hirsute.
2. S. Xanti.

2a. S. Xanti glabrescens.

3. S. Wallacei.

I. Solanum Douglasir Dunal, in DC. Prod. 13, pt. I: $48 . \quad$ I852. Solanum nigrum Douglasii A. Gray, Bot. Calif. 1: 538. 1876. Solanum umbelliferum trachycladum Torr. Pacif. R. Rep. 7: I7. I 856.

Type locality: "In Nova California."

Distribution: In the coastal region from Monterey southward to northern California. This native plant, more or less woody, and perennial, is clearly distinct from the European annual, S. nigrum, which occasionally appears as a wayside weed. Upper Sonoran.

Specimens examined: Playa del Rey, Abrams 1216; Inglewood, Abrams 2488; near Monrovia, Dudley, Dec. 1907; Sulphur Mountain, Abrams \& McGregor 23; Lone Pine Canyon, San Gabriel Mountains, Abrams \& McGregor 690.

2. Solanum Xanti A. Gray, Proc. Am. Acad. 11: 90. 1876. Solanum Xanti intermedium Parish, Proc. Calif. Acad. III. 2: I68. I901.

Type locality: Xantus' specimens were collected at Fort Tejon.

Distribution: Foothills of the Sierra Nevada, southward through southern California. Upper Sonoran.

Specimens examined: Cajon Pass, Hall 300o; Claremont, 
Chandler, I897; Nount Wilson, Abrams 2586; Campo, Abrams 3593; Sawpit Canyon, near Monrovia, Dudley, Dec. I8, I907; Liebre Mountain, Abrams \&ै McGregor 336; Rock Creek, Abrams E McGregor 597; Red Reef Canyon, Topatopa Mountains, Abrams E McGregor 154 .

2a. Solanum Xanti glabrescens (Torr.) Parish, Proc. Calif. Acad. III. 2: 169. Igor.

Solanum umbelliferum glabrescens Torr. Pacif. R. Rep. 7: 17 . 1856.

Type locality: "Santa Ynez; also between San Bernardino and San Gabriel."

Distribution: Southern Oregon southward to Lower California and northern Arizona. Upper and Lower Sonoran.

Specimens examined: Dry hillsides near San Dieguito, Abrams 3362; Oceanside, Parish 4437; San Diego, Palmer 260; San Ysabel, Henshaw, April 9, I893; La Mesa, Chandler 5059; Riverside, Hall 2929; San Bernardino, Parish 4384; between San Bernardino and San Gabriel, Antisell; Gaviota, Elmer 3957; vicinity of San Bernardino, Parish 4692; Lytle Creek Canyon, Hall r224; Sepulveda Canyon, Santa Monica Mountains, Abrams 2556.

3. Solanum Wallacei (A. Gray) Parish, Proc. Calif. Acad. III. 2: I66. I90I.

Solanum Xanti Wallacei A. Gray, Proc. Am. Acad. 11: 9I. 1876.

Type locality: "Island of Catalina off San Pedro, California."

Distribution: Foothills of Santa Ynez Mountains and on the islands off the coast of southern California. Upper Sonoran.

Specimens examined: Santa Catalina Island, Wallace; Santa Barbara, Wheelock, Feb. 24, 1893; Bartlette Canyon, Rothrock I3I; Mountain Drive, near Santa Barbara, Abrams 4I39.

\section{LYCIUM. BOX-THORN.}

Herbage not glandular-pubescent.

Calyx-lobes lanceolate, exceeding the tube.

I. L. Richii.

Calyx-lobes oblong or triangular, shorter than the tube.

Corolla-tube short, not exceeding the calyx.

2. L. californicum.

Corolla-tube about 3 times the length of the calyx. 
Herbage glabrous or nearly so; calyx-lobes triangular, much shorter than the tube.

Leaves mostly $2-3 \mathrm{~cm}$. long; calyx-lobes tomentose on the margins; filaments woolly at base. 3. L. Torreyi.

Leaves mostly less than I cm. long; calyx-lobes glabrous or nearly so; filaments sparsely hairy at base.

4. L. Andersonii.

Herbage pubescent; calyx-lobes oblong, nearly equaling the tube.

5. L. Parishii.

Herbage glandular-pubescent; corolla more or less pubescent.

$$
\text { 6. L. Cooperi. }
$$

I. Lycium Richir A. Gray, Proc. Am. Acad. 6: 46.1862. Lycium Hassei Greene, Pittonia 1: 222. 1888.

Type locality: "La Paz, South California."

Distribution: On the islands off the coast of soutbern California, and also on the mainland in the vicinity of San Diego. Upper and Lower Sonoran.

Specimens examined: Santa Catalina Island, Hasse, July I5, I888; San Diego, Susan G. Stokes, July, I895.

2. Lycium californicum Nutt.; A. Gray, Bot. Calif. 1: 542. 1876.

Type locality: "Near San Diego on clay-hill slopes."

Distribution: On bluffs near the sea and occasionally in subalkaline soils in the interior of southern California and northern Lower California. Upper and Lower Sonoran.

Specimens examined: San Diego, Nuttall; Palmer 262; Cooper, March, 1862; San Pedro Hills, near Rocky Point, Abrams 313I; Wilmington, Pringle, March 31, I882; Santa Monica, Parry 216; near Acton, Elmer 3757; Laguna Beach, Helen D. Geis 581 .

3. Lycium Torreyi A. Gray, Proc. Am. Acad. 6: 47. 1862.

Type locality: "Texas on the Rio Grande, to Fort Yuma, interior of California, along the Mexican boundary."

Distribution: Southern Utah, southward to western Texas, Chihuahua and Sonora. Lower Sonoran.

Specimens examined: Fort Yuma, Thomas, March 3, I855. 4. Lycium Andersonil A. Gray, Proc. Am. Acad. 7: 388. I 867. Lycium Andersonii Wrightii A. Gray, Bot. Calif. 1: 543. 1876. Type locality: "S. E. part of State of Nevada." 
Distribution: Southern Arizona and southern California on the Colorado Desert and in the vicinity of San Diego. Lower Sonoran.

Specimens examined: San Diego, Jones, April 5, I882; Abrams 3464; Tia Juana, Abrams 349I; Morongo Pass, S. B. छ $W . F$. Parish II-a; Palm Springs, Parish 4132; Mohave River, Palmer, May, I 876; Elsinore, Baker, 4145; Vallecitos, Brandegee, April ıo, 1896.

5. Lycium Parishit A. Gray, Proc. Am. Acad. 20: 305. I884. Type locality: "Mesas in San Bernardino Valley, S. California."

Distribution: This was described from a single bush which according to Mr. Parish has since been destroyed. The species has never been rediscovered. Lower Sonoran.

Specimens examined: Mesa south of San Bernardino, Parish, May, 1885.

6. Lycium Cooperi A. Gray, Proc. Am. Acad. 7: 388. 1867. Lycium Cooperi pubiflora A. Gray, Syn. Fl. 2, pt. I: $238 . \quad$ I 878. Type locality: "East slope of Providence Mountain, in the Mohave District, California."

Distribution: Mohave and Colorado Deserts, eastward to Arizona. Lower Sonoran.

Specimens examined: Between Calexico and Signal Mountain, on the International Boundary, Abrams 3149; Palmdale, Elmer 366I; Victor, Palmer 2231/2; Mohave Desert, Pringle, May 18, I882.

\section{NiCOTIANA. Toвacco.}

I. Nicotiana glauca R. Grah. Edinb. N. Phil. Journ. 175. I 828.

Type locality: "It was raised in 1827 from seeds communicated, without specific name, to the Royal Botanical Garden, Edinburgh, by Mr. Smith at Monkwood, whose son sent them from Buenos Ayres."

Distribution: The tree-tobacco, which is naturalized from South America, is frequent in waste places and along dry washes of streams, often found extending well up into the canyons. Upper and Lower Sonoran. 
Specimens examined: Gaviota, Elmer 3997; Santa Ana, Agnes M. Bowman, April, I899; Tia Juana, Susan G. Stokes, June, I895.

\section{SCROPHULARIACEAE. Figwort Family.}

Stamens 4 , the fifth represented by a sterile filament.

Stamens 4 , the fifth wholly wanting.
I. Pentstemon.

2. Diplacus.

\section{PENTSTEMON. BeARd-tongue.}

Corolla red; tube elongated, narrow; limb strongly bilabiate; leaves serrate or denticulate.

Leaves ovate; scandant over shrubs.

I. P. cordifolius.

Leaves linear-lanceolate, remote and often ternate on the virgate, herbaceous branches.

2. P.ternatus.

Corolla yellow or tinged with purple; tube short.

Leaves entire; sterile filament densely bearded. 3. P. antirrhinoides.

Leaves few-toothed; sterile-filament not bearded.

Stems and leaves puberulent.

Stems and leaves glabrous.

4. P. jacintensis.

5. P breviflorus.

I. Pentstemon cordifolius Benth. Scroph. Ind. Introd. 7. I 835 .

Type locality: "A new California species collected by $\mathrm{Mr}$. Douglas."

Distribution: Common in the chaparral belt, from Santa Barbara County to northern Lower California; also on the islands off the coast. Upper Sonoran.

Specimens examined: California, probably Santa Barbara, Douglas; Santa Barbara, Rich; Elmer 3956; Sepulveda Canyon, Santa Monica Mountains, Abrams 2545; Claremont, Baker 344I; Los Tunas Canyon, Santa Monica Mountains, Abrams I694; foothills, of the San Bernardino Mountains, Parish, July 8, I 898; Lytle Creek Canyon, Hall, June 17, I899; Jamul Valley, Palmer 273; Cottonwood Valley, Abrams 3905; Sycamore Canyon, San Diego County, Chandler 5328; Mission Valley, Susan G. Stokes, June, I895; Alpine, San Diego County, Mearns 3940; near Pasadena, Grinnell, July 3, I903; Santa Monica Canyon, Abrams 1468; Red Reef Canyon, Topatopa Mountains, Abrams E० McGregor I5O.

2. Pentstemon ternatus Torr. Bot. Mex. Bound. 2: il $5 . \quad$ I 859. Type locality: "Mountains east of San Diego." 
Distribution: Chaparral belt of the interior mountains of southern California. Upper Sonoran.

Specimens examined: Vicinity of Fort Tejon, Xantus 63; Acton, Elmer 3597; Pasadena, Mc Clatchie, June 28, 1893; Waterman Canyon, San Bernardino Mountains, Hall, July 13, I899; foothills, San Bernardino Mountains, Parish, June I, r898; Clark's ranch, San Bernardino Mountains, Abrams 2939; mountains east of San Diego, Parry, 1850 (type); Potrero, Susan G. Stokes, July, 1895; Abrams 3726; Claremont, Baker 5967; Julian, Palmer 274; Palomar Mountains, Chandler 544I; Chalk Hill, San Jacinto Mountains, Hall 2634; Oakgrove Canyon, Liebre Mountains, Abrams \& McGregor 394; Cajon Pass, Abrams छै McGregor 698.

3. Pentstemon antirrhinoides Benth.; A. DC. Prod. 10: 594. 1846.

Type locality: "In California." First collected by Coulter.

Distribution: In the chaparral of the low foothills and plains, from the vicinity of San Bernardino and the Santa Ana Mountains, southward to northern Lower California. Lower and Upper Sonoran.

Specimens examined: Colton, Jones 3178 ; near San Bernardino, Parish, May 26, 1898; Reche Canyon, Hall, May 17, I899; Elsinore, Mc Clatchie, May 20, 1893; near San Jacinto, Leiberg 3220; Foster, Hall 3879; San Miguel Mountain, Chandler 5273; Potrero, Abrams 3712; near Fallbrook, Abrams 3347; San Ysabel, Henshaw 146; Silverado Canyon, Santa Ana Mountains, Helen D. Geis 735; canyon of the San Jacinto River, Hall 20I6, June, I901.

4. Pentstemon jacintensis Abrams, Bull. Torrey Club 33: 445. 1906.

Type locality: "San Jacinto Mountain, altitude 9,000 feet." Distribution: Open pine forests of the San Jacinto Mountains. Transition.

Specimens examined: San Jacinto Mountain, S. B. छ $W . F$. Parish 473; Hall 704; Tahquitz Valley, Hall 2588; F. Grinnell, July, I908. 


\section{(453)}

5. Pentstemon breviflorus Lindl. Bot. Reg. 23: pl. 1946. 1837 .

Type locality: Collected by Douglas, probably near Monterey.

Distribution: Foothills of the Coast Ranges and the Sierra Nevada in Central California, extending southward to the Liebre Mountains in southern California. Upper Sonoran.

Specimens examined: Between Oakgrove Canyon and Elizabeth Lake, Abrams छ̋ McGregor 409.

\section{DIPLACUS. BUSH MONKEY-FLOWER.}

Flowers yellow or buff.

Corolla-tube much exceeding the calyx; lobes not erose-toothed; calyx and leaves not pubescent.

r. D. aridus.

Corolla-tube proper not exceeding the calyx; lobes erose-toothed; leaves pubescent beneath; calyx usually woolly.

Flowers scarlet; corolla-lobes not erose-toothed; calyx glabrous.

2. D. longiflorus.

3. D. puniceus.

I. Diplacus aridus Abrams, Bull. Torrey Club 32: 540. 1905.

Type locality: "Growing on dry rocky ridges at Jacumba near the boundary monument."

Distribution: Desert slopes of the Cuiamaca Mountains near the International Boundary. Upper Sonoran.

Specimens examined: Jacumba Hot Spring, Abrams 3656.

2. Diplacus longiflorus Nutt. Ann. Nat. Hist. 1: I39. 1838. Mimulus glutinosus brachypus A. Gray, Bot. Calif. 1: 566. I876. Diplacus arachnoideus Greene, Bull. Calif. Acad. 1: 2 IO. 1885. Diplacus calycinus Eastw. Bot. Gaz. 41: 287. 1906.

Type locality: "In rocky places by small streams, in the vicinity of Sta. Barbara (Upper California)."

Distribution: Southern Sierra Nevada and Santa Barbara County, southward to northern Lower California. Upper Sonoran.

The form with a glabrous calyx, which occurs in San Diego County, may be distinct, but the genus needs a thorough revision before more forms are segregated.

Specimens examined: Santa Barbara, Elmer 3959; Mission Canyon, near Santa Barbara, Eastwood I9; Los Angeles, Hasse, Oct. I887; Sepulveda Canyon, Santa Monica Mountains, Abrams 2543; vicinity of San Bernardino, Parish 4792; Ysidora, Abrams 3287; between Campo and Potrero, Abrams 3716. 
3. Diplacus Puniceus Nutt. Ann. Nat. Hist. 1: 137.1838.

Diplacus glutinosus puniceus Benth. DC. Prod. 10: $368 . \quad$ I844. Mimulus glutinosus puniceus A. Gray, Bot. Calif. 1: 566.1876.

T'ype locality: "In sandy loam by the borders of small winter streams, attaining commonly the height of a man, growing near to Sta. Diego, in Upper California."

Distribution: Riverside County and the Santa Ana Mountains, southward to northern Lower California, also on the islands off the southern California coast. Upper and Lower Sonoran.

Specimens examined: Vicinity of Riverside, Hall 2928; San Diego, Palmer 283; Thurber 545; San Luis Rey River, Parish 446I; Palomar Mountain, Hall, May 31, 1899; Ysidora, Abrams 3285; Mission Hills, San Diego, Hall 5053; Fallbrook, Jones 3439.

ACANThaCEAE. Acanthus Family.

\section{BELOPERONE.}

I. Beloperone californica Benth. Bot. Sulph. 38 . 1844 . Jacobina californica Nees, DC. Prod. 11: 729. 1847. Seriocographis californica A. Gray, in Torr. Bot. Mex. Bound. I25. 1859.

Type locality: "Cape San Lucas," Lower California.

Distribution: Colorado Desert of southern California, southward through the desert regions of Lower California. Lower Sonoran.

Specimens examined: Palm Springs, Parish 4136; Coyote Canyon, altitude 200 meters, Hall 2767; Vallecitos, Colorado Desert, Brandegee, March 26, Igor; near Coachella, Hall 5776.

Bignoniaceae. Trumpet-creeper Family.

I. CHILOPSIS. Flowering Willow.

I. Chilopsis linearis (Cav.) Sweet, Hort. Brit. 283. 1827.

Bignonia linearis Cav. Ic. 3: 35, pl. 269. 1794.

Chilopsis saligna Don. Edinb. Phil. Journ. 9: 261. 1823.

Type locality: Not given.

Distribution: Mohave Desert, southward and eastward to western Texas and Mexico. Growing along dry washes and stream 
beds of the desert mountains. In southern California extending into the coastal slope through the Morongo Pass. Lower Sonoran.

Specimens examined: Eastern base of San Jacinto Mountain, Hall 2II2; Warner's ranch, San Diego County, Susan G. Stokes, Aug. 1895; Cushenberry Springs, north slope of San Bernardino Mountains, Abrams 2142; San Felipe, Abrams 3979.

CAPRIfOliaCEAE. Honeysuckle Family.

Leaves pinnate; corolla rotate.

Leaves simple.

Corolla short-campanualte, regular; berry white.

Corolla tubular, irregular; berry red or black.
I. Sambucus.

2. Symphoricarpus.

3. Lonicera.

\section{SAMBUCUS. EldER.}

Fruit without bloom.

I. S. mexicana.

Fruit with a glacuous bloom.

Herbage pubescent.

Herbage glabrous.

2. S. velutina.

3. S. coerulea.

I. Sambucus mexicana Presl.; DC. Prod. 4: 322.1830.

Type locality: "In Mexico."

Distribution: Southern California to Texas and south through Mexico and Costa Rica, according to Schwerin. I have not seen any specimen that can be referred to this species with certainty. but fruiting material has been seldom collected, and it may be that some of the material referred to the next species belongs here.

*2. Sambucus velutina Dur. \& Hilg. Pacif. R. Rep. 5: 8. I855, Sambucus coerulea velutina Schwerin, Mitt. Deutsch. Dendr. Ges.

1909: 37, 328. I909.

Type locality: "Pose Creek," Kern County, California.

Distribution: Southern Sierra Nevada and the mountains of southern California. The herbage is usually densely pubescent, but occasionally nearly glabrous forms occur. Upper Sonoran and Transition.

Specimens examined: Bear Valley, San Bernardino Mountains, Hall I347; Mount San Antonio, altitude 2400 meters, Abrams 27ro;

*After this paper went to the printer Greene (Leaflets 2: 99) described several new species of Sambucus, one of which, Sambucus coriacea, is the pubescent form in the foothills of Santa Barbara and Ventura Counties. I had tentatively referred these plants to $S$. velutina. 
Water Canyon, Tehachapi Mountains, Abrams \& McGregor 493; Rock Creek, San Gabriel Mountains, altitude I 800 meters, Abrams E McGregor 596; Santa Barbara, Elmer 3836; Sulphur Mountain, Abrams \& McGregor 6; Red Reef Canyon, Topatopa Mountains, Abrams छै McGregor 139.

3. Sambucus coerulea Raf. Alsog. Am. 48. 1838.

Sambucus glauca Nutt. in Torr. \& Gray, Fl. N. Am. 2: 13. I84I.

Type locality: "Mentioned by Lewis and Clarke trav. 2, p. I60 as growing near Origon Mts."

Distribution: Idaho and Washington, southward through western Nevada and California to northern Lower California. In southern California this elder is common in the foothills and in both the coastal and interior valleys. Upper Sonoran.

Specimens examined: Vicinity of San Bernardino, Parish, 1898; Chatsworth, Abrams 1326; Sepulveda Canyon, Santa Monica Mountains, Abrams 2538; Oneonta, Chandler 5117; Jamacha, Chandler 5254; Fort Tejon, Abrams \& McGregor 299; Oakgrove Canyon, Liebre Mountains, Abrams $ళ 3$ McGregor 329; Swartout Canyon, San Gabriel Mountains, Abrams छै McGregor 630; Lone Pine Canyon, San Gabriel Mountains, Abrams \& McGregor 686; Tia Juana River, near the initial monument, Herre, Aug. 8, 1902.

\section{SYMPHORICARPUS Dill. SNOWBERRY.}

Corolla short-campanulate, lobes equaling the tube.

I. S. mollis.

Corolla tubular-funnelform, lobes shorter than the tube.

2. S. Parishii.

I. Symphoricarpus mollis Nutt. in Torr. \& Gray, Fl. N. Am. 2: 4. I84I.

Symphoricarpus ciliatus Nutt. in Torr. \& Gray, Fl. N. Am. 2: 4. I841.

Type locality: "St. Barbara, California."

Distribution: Coast ranges and foothills of the Sierra Nevada of central California, southward to the Cuiamaca Mountains. Upper Sonoran.

Specimens examined: Santa Barbara Nuttall; A. Gray, 1885; Sepulveda Canyon, Santa Monica Mountains, Abrams 347, 2552; Spencer Valley, near Julian, Abrams 3785; Mount Wilson, Grant 1260 . 
2. Symphoricarpus Parishil Rydb. Bull. Torrey Club 26:

545. 1899.

Type locality: "San Bernardino Mountains."

Distribution: San Gabriel Mountains, southward to the San Jacinto Mountains. Transition and Canadian Zones.

Specimens examined: Bear Valley, San Bernardino Mountains, Abrams 208I; Tamarack Valley, altitude 2700 meters, San Jacinto Mountains, Hall 2485; Swartout Canyon, San Gabriel Mountains, altitude 1950 meters, Abrams E McGregor 638; Dry Lake, San Bernardino Mountains, altitude 2700 meters, Abrams Eै McGregor 787.

\section{LONiCERA. Honeysuckle.}

Flowers in terminal clusters.

Inflorescence pubescent.

Uppermost leaves connate. I. L. hispidula californica.

Leaves all distinct.

Leaves tomentose beneath.

2. L. subspicata.

Leaves nearly or quite glabrous and green beneath.

Inflorescence glabrous.

Flowers on axillary peduncles, in pairs. 2a. L. subspicata denudata.

3. L. interrupta.

4. L. Ledebourii.

I. Lonicera hispidula californica (Torr. \& Gray) Rehder, Rep. Mo. Bot. Gard. 14: I78. I903.

Lonicera californica Torr. \& Gray, Fl. N. Am. 2: 7. I84I. Caprifolium californicum K. Koch, Hort. Dendr. 294. $\quad$ I 853.

Lonicera hispidula vacillans A. Gray, Proc. Am. Acad. 8: 628. ¿873.

Caprifolium hispidulum californicum Greene, Fl. Fran. 347. $\quad$ I892. Type locality: "At San Francisco, Douglas."

Distribution: British Columbia southward to the Sierra Nevada and Coast Ranges of central California. This species is not known on the mainland in southern California, but a form with "the inflorescence densely glandular-pubescent" has been collected on Catalina Island by Blanche Trask, according to Rehder.

2. Lonicera subspicata Hook. \& Arn. Bot. Beechy 349. 1840. Caprifolium subspicatum K. Koch, Hort. Dendr. 294. $\quad$ I 853. Lonicera hispidula subspicata A. Gray, Proc. Am. Acad. 8: 628. I 873 . 
Type locality: "California." First collected by Douglas, probably at Santa Barbara.

Distribution: Santa Barbara and Fort Tejon southward to the Santa Ana and San Jacinto Mountains. This is the common species in the chaparral of the coastal slope. Upper Sonoran.

Specimens examined: Santa Barbara, Douglas; Nuttall; Bartlett Canyon, Santa Ynez Mountains, Rothrock 124; Mountain Drive, near Santa Barbara, Abrams 4I48; near Santa Barbara, Elmer 3729; Sepulveda Canyon, Santa Monica Mountains, Abrams 367, Strawberry Valley, San Jacinto Mountains, Hall 2529; near Santa Ana, Helen D. Geis 518; Arroyo Seco, near Pasadena, Grinnell, June 27, 1903; Sawpit Canyon, San Gabriel Mountains, Dudley, Dec. 1907; Fort Tejon, Abrams छै McGregor 309; Cleghorn Canyon, San Bernardino Mountains, Abrams छ McGregor 704; Waterman Canyon, San Bernardino Mountains, Shaw छ Illingsworth 9, 226.

2a. Lonicera subspicata denudata Rehder, Rep. Mo. Bot. Gard. 14: 176. 1903.

Type locality: "San Diego," and also "Santo Thomas hills," Lower California.

Distribution: Foothills of San Diego County southward into Lower California. Upper Sonoran.

Specimens examined: San Diego, Thurber 558 (type); Susan G. Stokes, July 10, 1895; Spencer Valley, near Julian, Abrams 3804 (a form approaching the type); Chollas Valley, Orcutt 120.

\section{Lonicera interrupta Benth. Pl. Hartw. 313. 1849.}

Lonicera hispidula interrupta A. Gray, Proc. Am. Acad. 8: 628. I873.

Caprifolium interruptum Greene, Fl. Fran. 347. 1892.

Type locality: "Juxta carmel prope Monterey."

Distribution: Northern Coast Ranges and the Sierra Nevada southward to the desert slopes of the San Gabriel Mountains.

Specimens examined: Newhall, Hasse 605; Red Reef Canyon, Topatopa Mountains, Abrams \& McGregor I36; Oakgrove Canyon, Liebre Mountains, Abrams \& McGregor 326, 395; Swartout Canyon, San Gabriel Mountains, Abrams है McGregor 629. 
4. Lonicera Ledebouri Esch. Mem. Acad. Sci. Petersb. 10: 284. I 826.

Chamaecerasus Ledebourii Billiard, L'Hort. Franc. 1861: 256. I86I. Lonicera intermedia Kell. Proc. Calif. Acad. 1: 154. I863. Caprifolium Ledebourii Kuntze, Rev. Gen. Pl. 1: 274. I89I. Distegia Ledebourii Greene, Man. Bot. Bay Reg. 164. I894. Xylosteum Ledebourii Howell ,Fl. N. W. Am. 1: 282. 1900.

Lonicera involucrata Ledebourii Hort.; Zabel in Beissner, Schelle \& Label, Handb. Laubholz-Ben. 46I. I903.

Type locality: Collected by Eschscholtz, probably in the vicinity of San Franscisco.

Distribution: In moist shady places along streams; Santa Barbara northward through the Coast ranges and along the western slope of the Sierra Nevada to northern California. Transition and Upper Sonoran.

Specimens examined: Santa Barbara, Elmer 4138 .

\section{AMBROSIACEAE. Ragweed Family.}

Involucre of pistillate heads with broad silvery scarious wings.

Involucre of pistillate heads armed with several rows of prickles.

I. Hymenoclea.

2. Gaertneria.

\section{HYMENOCLEA.}

Involucral bracts of pistillate heads spirally alternate, $5 \mathrm{~mm}$. broad.

1. H. Salsola.

Involucral bracts of pistillate heads in a single whorl, I-2 $\mathrm{mm}$. broad.

2. H. monogyra.

1. Hymenoclea Salsola Torr. \& Gray, Pl. Fendl. 79. 1849.

Type locality: "Sandy, saline uplands near the Mohave River, in the interior desert of California." Transition and Upper Sonoran.

Distribution: A common shrub in the sandy washes throughout the desert region. Lower Sonoran.

Specimens examined: Palmdale, Elmer 3622; Mohave Desert, Brandegee; Whitewater, Vasey, Feb., I88ı; Palm Springs, Parish 4123; San Felipe, Vasey, June, 1880; Rock Creek, Abrams छ McGregor 542; Willow Springs, Abrams Eं McGregor 422. 
2. Hymenoclea monogyra Torr. \& Gray, Pl. Fendl. 79. 1849. Type locality: "Along the valley of the Gila."

Distribution: In the vicinity of San Diego and adjacent Lower California, eastward to western Texas. Lower Sonoran.

Specimens examined: Chollas Valley, Susan G. Stokes, Aug. 25, 1895; Mission Valley, San Diego, Brandegee, Aug. 1902; San Diego, Orcutt, Oct. II, 1883.

\section{GAERTNERIA.}

Spines of the bur straight.

Leaves pinnately parted; spines glabrous or minutely pubescent.

I. G. dumosa.

Leaves sinuate-toothed to sinuate-pinnatifid; spines villous.

2. G. eriocentra.

Spines of the bur uncinate.

Leaves petioled, crenately toothed.

Leaves clasping, coarsely spinose-dentate.

3. G. chenopodifolia.

4. G. ilicifolia.

I. Gaertneria dumosa (A. Gray) Kuntze, Rev. Gen. Pl. 1: 339. I891.

Franseria dumosa A. Gray, in Frem. Second Rep. 316. 1845.

Type locality: "On the sandy uplands of the Mohave River, and very common in all that region of North California."

Distribution: A very common and characteristic shrub of the Mohave and Colorado Deserts, extending eastward to southern Utah, and southward into northern Mexico and Lower California. Lower Sonoran.

Specimens examined: Signal Mountain, Imperial County, Abrams 3179; Mohave Desert, Brandegee; Palm Springs, Parish $412 I$.

2. Gaertneria eriocentra (A. Gray) Kuntze, Rev. Gen. Pl. 1: 339. 1891 .

Franseria eriocentra A. Gray, Proc. Am. Acad. 7: 355. 1868.

Type locality: "East slope of Providence Mountain, Arizona."

Distribution: From the Providence Mountains, eastward through southern Nevada and adjacent Arizona. Lower Sonoran.

Specimens examined: I have not seen any specimens from southern California. 


\section{$(46 \mathrm{I})$}

\section{Gaertneria chenopodifolia (Benth.)}

Franseria chenopodifolia Benth. Bot. Sulph. 26. 1844.

Type locality: "Bay of Magdalena."

Distribution: On the south slopes of hills at Tia Juana, and extending southward into Lower California. Lower Sonoran.

Specimens examined: Tia Juana, Abrams 3476.

4. Gaertneria ilicifolia (A. Gray) Kuntze, Rev. Gen. Pl. 1: 339. I891.

Franseria ilicifolia A. Gray, Proc. Am. Acad. 11: $77 . \quad$ I876.

Type locality: "Great Canyon of the Tantillas Mountains, near the northern border of Lower California."

Distribution: Colorado Desert along the southern border of the State, extending southward on the desert slopes of Lower California. Lower Sonoran.

Specimens examined: Signal Mountain, Abrams 3184.

\section{ASTERACEAE. Aster Family.}

Anthers not caudate at base.

Receptacle naked.

Pappus of capillary-bristles, except Gutierrezia; involucral bract not scarious-margined.

Involucral bracts imbricated.

Involucral bracts striate; style-branches thickened above, stigmatic only below the middle. I. Eupatorieae.

Involucral bracts not striate; style-branches with flattened terminal appendages, stigmatic to above the middle.

2. Astereae.

Involucral bracts in $\mathbf{I}$ or 2 series, not imbricated, except Lepidospartum; style-branches stigmatic to the summit.

6. Senecioneae.

Pappus not of capillary-bristles; involucral bracts imbricated, scarious-margined.

Receptacle with chaffy bracts.

Anthers caudate at base.

5. Anthemideae.

4. Heliantheae.

3. Inuleae.

TRIBE I. Eupatorieae.

Achenes 5-angled or 5-ribbed.

1. Hofmeisteria.

Achenes ro-nerved.

2. Coleosanthus.

Rays present, yellow.

Tribe 2. Astereae.

Pappus of several short scales; heads small; slender, suffrutescent plants.

3. Gutierrezia. 
Pappus of capillary bristles.

Heads solitary, terminating naked peduncles. 5. Stenotopsis.

Heads not terminating naked peduncles, seldom solitary.

Rays none.

6. Ericameria.

Flowers perfect, yellow.

Pappus white or yellowish.

Pappus-bristles all slender.

Involucral bracts not in distinct vertical ranks; herbage resinous-punctate.

6. Ericameria.

Involucral bracts in distinct vertical ranks; only the first two species resinous-punctate.

7. Chrysothamnus.

Pappus-bristles, at least some, with flattened tips.

4. Acamptopappus.

Pappus tawny; bracts well-imbricated, squamose.

8. Hazardia.

Flowers dioecious, whitish.

9. Baccharis.

TRIBE 3. Inuleae.

Willow-like shrub, with silvery appressed pubescence. Io. Pluchea.

\section{Tribe 4. Heliantheae.}

Pappus of plumose-bristles, rays none.

I1. Bebbia.

Pappus of scales; rays present or none.

Disk-achenes thick, 4 - or 5-angled, not winged.

Disk-achenes flattened, the acute angles ciliate or winged.

12. Viguiera.

13. Encelia.

Trine 5. Anthemideae.

Spinescent undershrub; achenes and flowers cobwebby. 14. Picrothamnus. Not spinescent; achenes and flowers not cobwebby. I5. Artemisia.

Tribe 6. Senecioneae.

Involucral bracts in 3 or 4 series, imbricated; leaves scale-like.

Involucral bracts in $\mathbf{I}$ or 2 series.

16. Lepidospartum.

Bracts of the involucre many, linear to subulate.

Heads discoid.

Heads radiate.

17. Peucephyllum.

19. Senecio.

Bracts of the involucre $4^{-6}$, broad and obtuse.

18. Tetradymia.

\section{HOFMEISTERIA.}

I. Hofmeisteria pluriseta A. Gray, Pacif. R. Rep. 4: 96, pl. 9. 1857 .

Type locality: "In a canyon at Bill William's fork, northern Arizona." 
Distribution: Rocky places through the Mohave and the Colorado Deserts of southern California, eastward to Arizona and southern Utah. Lower Sonoran.

Specimens examined: Palm Springs, Parish 4I22; Camp Cady, Hall $6{ }_{3} 3$.

\section{COLEOSANTHUS.}

Heads campanulate, terminating corymbose branchlets.

Leaves ovate, rounded or cordate at base.

Herbage scabrous-atomiferous, green.

Herbage white-tomentose.

I. C. atractyloides.

2. C. incanus.

Leaves linear to oblong or obovate, narrowed at base.

Inner involucral bracts acuminate; leaves $15-30 \mathrm{~mm}$. long.

3. C. linifolius.

Inner involucral bracts merely acutish; leaves $5^{-15} \mathrm{~mm}$. long.

4. C. frutescens.

Heads turbinate, paniculate or glomerate.

Herbage white-tomentose; involucral bracts acute. 5. C. Nevinii.

Herbage greenish (except 7); involucral bracts acute.

Leaves ovate; heads ro-I5-flowered.

Involucre 10-1 $2 \mathrm{~mm}$. high.

Involucre 7-8 $\mathrm{mm}$. high.

Leaves lanceolate; heads 5 -flowered.

6. C. californicus.

7. C. desetorum.

8. C. Knappianus.

I. Coleosanthus atractyloides (A. Gray) Kuntze, Rev. Gen. Pl. 1: 328. 1891.

Brickellia atractyloides A. Gray, Proc. Am. Acad. 8: $290 . \quad$ I870.

Type locality: "Utah, near the Rio Colorado."

Distribution: The Mohave and Colorado Deserts of southern California, eastward to Arizona and southern Nevada. Lower Sonoran.

Specimens examined: Near Palm Springs, S. B. छ W. F. Parish I2IO; northern base of the San Bernardino Mountains, Parish 3710; Cushenberry Spring, Parish 2387; Colorado Desert, Brandegee, I901; no locality, Parry छ Lemmon 158; Rabbit Springs, Parish 4875; Providence Mountains, Brandegee, May 27, 1902.

2. Coleosanthus incanus (A. Gray) Kuntze, Rev. Gen. Pl. 1: 328. 1891 .

Brickellia incana A. Gray, Proc. Am. Acad. 7: 350. 1868.

Type locality: "Providence Mountain, in the Mohave district."

Distribution: In dry washes of the Mohave Desert, eastward to southern Nevada. Lower Sonoran. 


\section{(464)}

Specimens examined: Providence Mountains, Cooper, I860-6r; dry washes near Mohave River, S. B. \& W. F. Parish I248; Cushenberry Springs, Parish 2388.

3. Coleosanthus linifolius (Eaton) Kuntze, Rev.

Gen. Pl. 1: 328. I891.

Brickellia linifolia Eaton, Bot. King. Exp. 137, pl. I5, fig. I-6. I871.

Brickellia mohavensis A. Gray, Syn. Fl. 1, pt. 2: 104. 1884.

Type locality: "Sandy bottoms of American Fork, Jordan Valley, Utah."

Distribution: Gravelly places in the Mohave and Colorado Deserts, eastward to Arizona and Colorado. Lower Sonoran.

Specimens examined: Cactus Flat, Cushenberry Canyon, north slope of the San Bernardino Mountains, Parish 3III; eastern base of San Jacinto Mountain, Hall 2142; Providence Mountains, Brandegee, May 26, 1902.

4. Coleosanthus frutescens (A. Gray) Kuntze, Rev. Gen. Pl. 1: 328. I891.

Brickellia frutescens A. Gray, Proc. Am. Acad. 17: $207 . \quad$ I 882. Type locality: "Mountain Springs, San Diego Co."

Distribution: Dry gravelly ridges on the desert slope of the Cuiamaca Mountains, southward into adjacent Lower California. Lower Sonoran.

Specimens examined: Jacumba Hot Spring, Abrams 3665.

5. Coleosanthus Nevini (A. Gray) Heller, Cat. N. Am. Pl. 8. I898.

Brickellia Nevinii A. Gray, Proc. Am. Acad. 20: 297. I884. Type locality: "Los Angeles Co., California, near Newhall."

Distribution: Mountains of Ventura County, southward to the southern slopes of the San Gabriel Mountains. Upper Sonoran.

Specimens examined: Hot Springs Canyon, Ventura County, Abrams Es McGregor I92; San Antonio Canyon, Baker 373I; near Sherman, Braunton I7; Greata 33I.

6. Coleosanthus californicus (Torr. \& Gray) Kuntze, Rev. Gen. Pl. 1: 328. I891.

Bulbostylis californica Torr. \& Gray, Fl. N. Am. 2: 79 . 1840. 
Brickellia californica (Torr. \& Gray) A. Gray, Pl. Fendl. 64. I849. Type locality: "California." First collected by Douglas.

Distribution: Mendocino County and the foothills of the Sierra Nevada, southward to northern Lower California. In southern California this species is common on the coastal slope, growing in washes and on dry ridges in the chaparral. Upper Sonoran.

Specimens examined: Santa Barbara, Elmer 4I89; Arroyo Seco, near Pasadena, Grinnell, Nov. 14, I903; Elysian Park, Los Angeles, Abrams 4I73; San Antonio Canyon, San Gabriel Mountains, Baker 3696; foothills of the San Bernardino Mountains, S. B. छ W. F. Parish 566; San Diego, Cleveland, I 874; Santiago Canyon, Santa Ana Mountains, Helen D. Geis 523; Campo, Palmer I7I.

7. Coleosanthus desetorum Coville, Cont. Nat. Herb. 4: i ig. I 893 .

Brickellia desetorum Coville, Proc. Biol. Soc. Wash. 7: 68. 1892. Brickellia californica desetorum (Coville) Hall, Univ. Calif. Pub. Bot. 3: 33. 1907.

Type locality: "Between Banning and Seven Palms, on the Southern Pacific Railroad, California."

Distribution: Growing in canyons on the desert slopes along the Colorado and Mohave deserts. Lower Sonoran.

Specimens examined: Dos Cabesas, Orcutt, Nov. I, I89o.

8. Coleosanthus Knappianus (Drew) Greene, Erythea 1: 54. I893.

Brickellia Knappiana Drew, Pittonia 1: 260. I888.

Type locality: "In the neighborhood of the Mohave River."

Distribution: In the more eastern and northern part of the Mohave Desert, perhaps not within our range. Lower Sonoran.

Specimens examined: Pleasant Canyon, Panamint Mountains, Hall है Chandler 6019.

\section{GUTIERREZIA.}

Flowers of ray and disk $\mathbf{I}-2$ each.

I. G. lucida.

Flowers of ray and disk several each.

Ultimate branchlets ascending, destitute of bract-like leaves.

2. G. divergens.

Ultimate branchlets strictly divaricate, clothed with very short bract-like leaves.

3. G. bracteata. 
These species are scarcely more than suffrutescent, and probably could be excluded with equal propriety.

I. Gutierrezia lucida Greene, Fl. Franc. 361. 1897. Xanthocephalum lucidum Greene, Pittonia 2: 282. 1892.

Type locality: "In the region of the Mohave Desert, and southward."

Distribution: Dry gravelly hillsides in the Mohave Desert. Lower Sonoran.

Specimens examined: Between Mohave and Rosemond, Abrams छ McGregor 506.

2. Gutierrezia divergens Greene, Pittonia 4: 58. 1899.

Type locality: "San Bernardino mesas."

Distribution: Dry mesas and foothills in the coastal region of southern California. Upper and Lower Sonoran.

Specimens examined: Los Angeles, Nevin, 1879; Brandegee; San Gabriel Canyon, Abrams 2720; Los Angeles, Gambel; Tia Juana, Herre, Aug. 8, I902; vicinity of San Bernardino, Parish 5I5I; El Toro, Abrams 1858; Santiago Canyon, Santa Ana Mountains, Helen D. Geis 573; Alpine, San Diego County, Mearns 3997.

3. Gutierrezia bracteata Abrams, Bull. Torrey Club 34: 265. 1907.

Gutierrezia californica bracteata Hall, Univ. Calif. Pub. Bot. 3: 36 . 1907.

Gutierrezia laricina Greene, Rep. Nov. Spec. 7: 195. 1909.

Type locality: "Desert slopes of San Bernardino County, between Banning and Seven Palms."

Distribution: Dry sandy soil on the western border of the Colorado Desert. Lower Sonoran.

Specimens examined: Between Banning and Seven Palms, Orcutt, Nov. 1889.

\section{ACAMTOPAPPUS.}

I. Acamtopappus sphaerocephalus Harv. \& Gray; A. Gray, Pl. Fendl. 76. 1849.

Type locality: "California." First collected by Coulter.

Distribution: In the covillea belt of the Colorado and Mohave Deserts, eastward to Arizona and southern Utah. Lower Sonoran. 
Specimens examined: Mohave Desert, Pringle, May 24, I882; San Felipe, Antisell; Lancaster, Elmer 362I; eastern base of San Jacinto Mountain, Hall 2108; Barstow Hills, Hall 6r59; Palmdale, Abrams Eं McGregor 513; Willow Springs, Abrams ह० McGregor 423.

\section{STENOTOPSIS.}

Leaves thin, mostly $4-5 \mathrm{~cm}$. long; involucral bracts over $\mathrm{I} \mathrm{cm}$. long; achenes $5 \mathrm{~mm}$. long.

I. S. linearifolius.

Leaves coriaceous, glutinous, less than $2 \mathrm{~mm}$. long; involucral bracts less than $\mathrm{I} \mathrm{cm}$. long; achenes $3.5 \mathrm{~mm}$. long.

2. S. interior.

I. Stenotopsis linearifolius (DC.) Rydb. Bull. Torrey Club 27: 6r7. rgoo.

Aplopappus linearifolius DC. Prod. 5: 347 . 1836.

Stenotus linearifolius Torr. \& Gray, Fl. N. Am. 2: 238.1842.

Type locality: "In California."

Distribution: Foothills of the Coast Ranges from Sonoma County, southward to northern Lower California, and also on the western slope of the Sierra Nevada (Marysville Buttes, Heller 5558). Upper Sonoran.

Specimens examined: Cajon Pass, Orcutt, I883; vicinity of San Bernardino, Wright, I88ı; Coahuilla Hills, Riverside County, altitude 900 meters, Hall 2902; Potrero, Abrams 3549.

2. Stenotopsis interior (Coville) Rydb. Bull. Torrey Club 27: 617. 1900.

Aplopappus interior Coville, Proc. Biol. Soc. Wash. 7: 65. I 892. Stenotus interior Greene, Erythea 2: 72. 1894.

Stenotus linearifolius interior Hall, Univ. Calif. Pub. Bot. 3: 48. 1907.

Type locality: "About 4 miles southeast from Mill Canyon Divide, at the northern edge of the Darwin Mesa, Inyo County, California."

Distribution: On the western borders of the Mohave and Colorado Deserts, eastward to Arizona and southern Utah. Lower Sonoran.

Specimens examined: Mountains Springs, Vasey 260; Jacumba Hot Spring, Abrams 3647; Mount Pinos, Elmer 3993; near Cuddy's ranch, Ventura County, Dudley 4506; Seymons Creek, Mount Pinos, 
Hall 6498; Soldiers' Camp near Fort Tejon, Abrams E McGregor 276.

\section{ERICAMERIA.}

Leaves glabrous, glandular-punctate; style-appendages filiform-subulatc.

Leaves not filiform.

Leaves obovate or oblanceolate; low, spreading shrub; branches $\mathbf{I}-2$ $\mathrm{dm}$. long.

I. E. cuneata spathulata.

Leaves flat, linear-lanceolate; erect shrub, I-3 m. high.

\section{E. Parishii.}

Leaves filiform.

Rays wanting.

Inflorescence cymose.

3. E. arborescens.

Inflorescence paniculate. $\quad 4$. E. brachylepis.

Rays present.

Achenes pubescent.

Outer involucral bracts obtuse. 5. E. Palmeri.

Outer involucral bracts acuminate.

6. E. pinifolia.

Achenes glabrous; outer involucral bracts acute.

7. E. ericoides.

Leaves minutely pubescent, often obscurely glandular-punctate; style-appendages oblong-ovate.

8. E. monactis.

I. Ericameria cuneata spathulata (A. Gray) Hall, Univ. Calif. Pub. Bot. 3: 52.1907.

Bigelovia spathulata A. Gray, Proc. Am. Acad. 11: 74. 1876. Bigelovia rupestris Greene, Bot. Gaz. 6: 183. I881.

Chrysoma cuneata spathulata Greene, Erythea 3: II. I895.

Chrysoma Merriami Eastw. Bull. Torrey. Club 32: 214. 1905.

Type locality: "Near the entrance of the Tantillas Great Canyon, in Lower California, near the borders of the State."

Distribution: On rocky ledges from the San Gabriel Mountains southward into northern Lower California. Upper Sonoran.

Specimens examined: Cucamongo Mountains, S. B. छ $W . F$. Parish 1027; San Gabriel Canyon, Abrams 853; Hines Peak, Topatopa Mountains, Abrams \& McGregor 85. (Closely resembling the typical form, but not in bloom, and therefore placed here doubtfully.)

2. Ericameria Parishii (Greene) Hall, Univ. Calif. Pub. Bot. 3: 55. 1907.

Bigelovia Parishii Greene, Bull. Torrey Club 9: 62. 1882.

Chrysoma Parishii Greene, Erythea 3: 10. 1895. 
Aster Parishii Kuntze, Rev. Gen. Pl. 1: 318. I89ı.

Type locality: "San Bernardino Mountains, California."

Distribution: Western slope of the San Gabriel Mountains, southward to northern Lower California. Upper Sonoran.

Specimens examined: San Bernardino Mountains, 450-750 meters altitude, S. B. E W.F. Parish $57 I$; canyons of the San Bernardino Mountains, Parish, Sept., I900; San Gabriel Canyon, altitude 750 meters, Abrams 850; Waterman Canyon, Parish 4584; Lytle Creek, altitude 650 meters, Abrams 1961; San Felipe, Susan G. Stokes, July, I895; Cuiamaca Mountains, altitude $\mathbf{2} 200$ meters, Susan G. Stokes, June 20, 1895.

3. Ericameria arborescens (A. Gray) Greene, Man. Bay Reg. I75. I894.

Linosyris arborescens A. Gray, Bot. Mex. Bound. 79. 1859.

Chrysoma arborescens Greene, Erythea 3: I0. 1895.

Bigelovia arborescens A. Gray, Proc. Am. Acad. 8: 638. 1873.

Type locality: "California."

Distribution: In the Coast Ranges and Sierra Nevada of central California, extending southward to the Santa Ynez Mountains. Upper Sonoran.

Specimens examined: La Cumbre Peak, Santa Ynez Mountains, Abrams 4317 .

4. Ericameria brachylepis (A. Gray) Hall, Univ. Calif. Pub. Bot. 3: 56.1907.

Bigelovia brachylepis A. Gray, Bot. Calif. 1: 6I4. 1876.

Chrysoma brachylepis Greene, Erythea 3: 12. 1895.

Type locality: "Larken's Station, 80 miles east by north of San Diego."

Distribution: Along the southern border of San Diego County, and extending southward into adjacent Lower California. Lower and Upper Sonoran.

Specimens examined: Larken's Station, Palmer, 1875 (type); Potrero, Cleveland, 1876.

5. Ericameria Palmeri (A. Gray) Hall, Univ. Calif. Pub. Bot. 3: 53. 1907.

Aplopappus Palmeri A. Gray, Proc. Am. Acad. 11: 74. 1876. Chrysoma Palmeri Greene, Erythea 3: 12. 1895. 
Aster Nevinii Kuntze, Rev. Gen. Pl. 1: 316. I891.

Type locality: "Tecate Mountains, Lower California, twenty or thirty miles below the state boundary."

Distribution: On dry sandy plains and foothills of the coastal slope of southern California, extending southward into northern Lower California. Upper and Lower Sonoran.

Specimens examined: San Gorgonio Pass, Parry; mesas about San Bernardino, S. B. छ W. F. Parish 654; Parish 5127; Inglewood, Abrams 4201 .

6. Ericameria pinifolia (A. Gray) Hall, Univ. Calif. Pub. Bot. 3: 54. 1907 .

Aplopappus pinifolius A. Gray, Proc. Am. Acad. 8: 636. 1873. Chrysoma pinifolia Greene, Erythea 3: I2. 1895. Aster pityphyllus Kuntze, Rev. Gen. Pl. 1: 316. 1891.

Type locality: "Near Los Angeles, in dry river-beds."

Distribution: On the dry plains and foothills from the vicinity of Los Angeles, southward to the southern boundary of the State. Upper and Lower Sonoran.

Specimens examined: Los Angeles, Bolander, I873 (type); Nevin, 1879; vicinity of San Bernardino, Parish 4202; Wright, 1880; Lytle Creek Canyon, Abrams 2744; vicinity of San Bernardino, Parish 5130 (in part-the leafless branch is Lepidospartum squamatum); Big Tejunga wash, Abrams 1372; Potrero, Susan G. Stokes, July 14, 1895; Cajon Pass, Abrams Eै McGregor 696; near Julian, Orcutt, Oct., I889; Soledad Pass, Pringle, Oct. 21, I882.

7. Ericameria ericoides (Less.) Jepson, Fl. W. Mid. Calif. 559. IgOI.

Diplopappus ericoides Less. Linnaea 6: I17. I831. Aplopappus ericoides Hook. \& Arn. Bot. Beech. I46. 1833. Ericameria microphylla Nutt. Tranз. Am. Phil. Soc. II. 7: 329. I840.

Chrysoma ericoides Greene, Erythea 3: II. 1895. Aster ericinus Kuntze, Rev. Gen. Pl. 1: 313. I891.

Type locality: "Cel. de Chamisso in California," probably at San Francisco.

Distribution: Sand-dunes along the coast from central California south to Los Angeles County. Upper Sonoran.

Specimens examined: Playa del Rey, Abrams 199. 
8. Ericameria monactis (A. Gray) McClatchie, Erythea 2: I24. I894.

Aplopappus monactis A. Gray, Proc. Am. Acad. 19: I. 1883. Acamptopappus microcephalus Jones, Contr. W. Bot. no. 8: 33 . I898.

Tumionella monactis Greene, Leaflets 1: I73. 1906.

Chrysothamnus corymbosus Elmer, Bot. Gaz. 39: 50. 1905.

Type locality: "Borders of the Mohave Desert, S. E. California."

Distribution: Mohave Desert from Owens Valley south to Cajon Pass. This species has also been reported as occurring on the coastal slope in the vicinity of West Riverside. Lower Sonoran.

Specimens examined: Mohave River, Palmer I99 (type); head of Cajon Pass, S. B. छ W. F. Parish 905; north slopes of San Bernardino Mountains, S. B. छ W. F. Parish 1246; Mohave Desert, Pringle, May, I882; Lancaster, Elmer 3668; near Sprague's Ranch, Liebre Mountains, Dudley 4370; near Barstow, Hall 6160; Willow Springs, Antelope Valley, Abrams छ McGregor 4 II

\section{CHRYSOTHAMNUS.}

Leaves resinous-punctate, terete.

Outer involucral-bract with a distinct greenish subapical spot.

Outer involucral bracts pale, without greenish spot.

1. C. teretifolius.

2. C. paniculatus.

Leaves not resinous-punctate, plane or canaliculate.

Branches not tomentose; leaves glabrous except on the margins.

Stems glutinous; leaves not ciliate, often sparse.

3. C. mohavensis.

Stems not glutinous, leafy; leaves short-ciliate on the margins.

Branches more or less tomentose.

4. C. stenophyllus.

Heads 5 -flowered.

Bracts abruptly contracted to a spreading setiform tip.

5. C. ceruminosus.

Bracts acute or acuminate.

6. C. occidentalis.

Heads 9-flowered; a few of the outer bracts foliaceous.

7. C. Parryi.

I. Chrysothamnus teretifolius (Dur. \& Hilg.) Hall, Univ. Calif. Pub. Bot. 3: 57. I 907.

Linosyris teretifolia Dur. \& Hilg. Pacif. R. Rep. 5: 9, pl. 7. 1855. Bigelovia teretifolia A. Gray, Proc. Am. Acad. 8: 644. 1873. 
Chrysoma terctifolia Greene, Erythea 3: I2. I895.

Type locality: "All over the mountains around Tejon Valley."

Distribution: On the desert slopes of the mountains of southern California from Tejon Pass southward to the Cuiamaca Mountains (according to Gray), and eastward to southern Nevada. Lower Sonoran.

Specimens examined: Mountains around Tejon Valley, Heerman (type); Morongo Pass, Parry; San Gorgonio Pass, S. B. छ W. F. Parish 655; hills bordering the Mohave Desert, Pringle, Oct. 21, I882.

2. Chrysothamnus paniculatus (A. Gray) Hall, Univ. Calif. Pub. Bot. 3: 58 . 1907.

Linosyris viscidiflora paniculata A. Gray, Bot. Mex. Bound. 80. 1859.

Bigelovia paniculata A. Gray, Proc. Am. Acad. 8: 644. I873. Chrysoma paniculata Greene, Erythea 3: 12. I895.

Type locality: "California, Schott, probably in the southeastern part of the State: the station not recorded."

Distribution: On the Mohave and the Colorado Deserts of southern California, and extending into Arizona and southern Nevada. Lower Sonoran.

Specimens examined: California, locality not given, Schott (type); desert mountains, station not given, S. B. छ W. F. Parish 65I; desert washes, Parry, 1875; Whitewater, S. B. E W. F. Parish 655; Larken's Station (Jacumba Hot Spring), Palmer, 1875.

3. Chrysothamnus mohavensis Greene, Erythea 3: il 3. 'i 895. Bigelovia mohavensis Greene, A. Gray, Syn. Fl. 1, pt. 2: 138. 1884.

Aster mohavensis Kuntze, Rev. Gen. Pl. 1: 3 I8. 189 I.

Type locality: "On the Mohave Desert."

Distribution: Mohave Desert, from the Tehachapi Mountains southward to the desert slopes of the San Bernardino Mountains. Lower Sonoran.

Specimens examined: Tehachapi Pass, Eastwood, Sept. I894; Mohave Desert, Pringle, Oct., 1882; Fort Tejon, Rothrock 27I; San Bernardino Mountains, S. B. छ W. F. Parish 1072; Cushenberry Springs, north slope of San Bernardino Mountains, Abrams 2145; Rock Creek, Abrams E̋ McGregor 625. 
4. Chrysothamnus stenophyllus (A. Gray) Greene, Erythea 3: 94. I 895.

Bigelovia Douglasii stenophylla A. Gray, Proc. Am. Acad. 8: 646. 1873.

Chrysothamnus viscidiflorus stenophyllus Hall, Univ. Calif. Pub. Bot. 3: 59. 1907.

Type locality: "Northwestern Nevada."

Distribution: Western Nevada and the eastern slope of the Sierra Nevada, southward to the San Bernardino Mountains. In the more arid parts of the Transition Zone.

Specimens examined: Bear Valley, San Bernardino Mountains, S. B. छ० W. F. Parish I454; Abrams 2133, 2889.

\section{Chrysothamnus ceruminosus (Dur. \& Hilg.) Greene,}

Erythea 3: 94. I 895 .

Linosyris ceruminosa Dur. \& Hilg. Pacif. R. Rep. 5, pt. 3: 9, pl. 6. 1855 .

Bigelovia ceruminosa A. Gray, Proc. Am. Acad. 8: 643. I873. Type locality: "Tejon Pass."

Distribution: This species was collected by Dr. Heerman, of the Pacific Railway Survey, in the region of Tejon Pass, but has never been rediscovered.

6. Chrysothamnus occidentalis Greene, Fl. Fran. 369. 1897. Chrysothamnus californicus occidentalis Greene, Erythea 3: II2. I 895 .

Chrysothamnus nauseosus occidentalis Hall, Univ. Calif. Pub. Bot. 3: 60. 1907.

Type locality: "In the Coast Ranges from Humboldt County southward." Later (Fl. Fran.) Greene gives the range as "Kern and Santa Barbara counties."

Distribution: Mountains of Santa Barbara County and southern Kern County, southward to the San Jacinto Mountains. Transition.

Specimens examined: Green Valley, Shaw E' Illingsworth 55.

7. Chrysothamnus Parryi (A. Gray) Greene, Erythea 3: II3. 1895.

Linosyris Parryi A. Gray, Proc. Philad. Acad. 1863: 63. I863. Bigelovia Parryi A. Gray, Proc. Am. Acad. 8: 642. 1873. 
Type locality: "Rocky Mountains of Colorado in the region of South and Middle Park," according to Gray (Proc. Am. Acad. 8: 642).

Distribution: A Rocky Mountain species of rather high altitudes which occurs on Alamo Mountain, altitude 2100 meters, eastern Ventura County, according to Hall (Univ. Calif. Pub. Bot. 3: 62. 1907).

\section{HAZARDIA.}

I. Hazardia squarrosa (Hook. \& Arn.) Greene, Erythea 2: il 2. I894.

Aplopappus squarrosus Hook. \& Arn. Bot. Beechey I46. 1833.

Type locality: Probably Monterey. "Collected at San Francisco, and a few at Monterey Bay" is the general locality given at the head of the list of plants in which this species appears.

Distribution: Monterey, southward to San Diego, and on the islands off the coast of southern California. Upper Sonoran.

Specimens examined: Mountain Drive, near Santa Barbara, Eastwood 20I; Abrams 4147; Los Angeles, Hasse, Oct., I887; Elysian Park, Abrams 4I80; San Antonio Canyon, Baker 3732; San Diego, Brandegee, Sept. I3, I902 (Baker 3426); San Ysabel, Hayes 395.

\section{BACCHARIS.}

Achenes Io-nerved; leaves not willow-like.

Pappus of fertile flowers conspicuously elongating in fruit, flaccid.

Leaves except some of the uppermost not linear.

Leaves obovate, sessile; pappus, in fruit, about $8 \mathrm{~mm}$. long.

I. B. pilularis.

Leaves of branches oblanceolate or oblong, those of the branchlets linear; heads somewhat nakedly paniculate.

2. B. Emoryi.

Leaves all linear, rigid, those of the strongly striated branchlets sparse and minute; involucre of male flowers $3-4 \mathrm{~mm}$. long.

3. B. sarothroides.

Pappus of fertile flowers rather rigid and scanty, not elongated in age;

branches broom-like.

Achenes 5-nerved or rarely 4-nerved.

4. B. sergiloides.

Leaves willow-like, glabrous and sometimes glutinous.

Involucre 5-6 mm. long; bracts stramineous. 5. B. glutinosa.

Involucres $8 \mathrm{~mm}$. long; bracts tawny. $\quad 6 . B$ viminea.

Leaves pubescent, linear-oblong, obtuse, acutely serrate.

7. B. Plummerae. 


\section{$(475)$}

I. Baccharis pilularis DC. Prod. 5: $407 . \quad$ I 836.

Baccharis consanguinea DC. Prod. 5: 408. 1836.

Type locality: "In California." First collected by Douglas.

Distribution: Coastal region of Oregon, southward to Santa Monica, southern California. In southern California this species is local at Santa Monica, but is more frequent in the coastal region of Santa Barbara and Ventura Counties. Upper Sonoran.

Specimens examined: Santa Catalina Island, Blanche Trask, Sept., I897; Santa Barbara, Atrams, Aug., 1909.

2. Baccharis Emoryi A. Gray, Bot. Mex. Bound. 83. 1859.

Type locality: "Very common on the Gila; Emory, coll. in 1846 , etc. Fort Yuma, E. California; Major Thomas." Emory's specimen in the Gray Herbarium is a mere fragment, and the original description, at least of the pistillate plant was undoubtedly drawn from Thomas' plant.

Distribution: Western Arizona and southern Utah, westward to the coastal region of southern California. Upper and Lower Sonoran.

Specimens examined: Near Los Angeles, Nevin, I880; San Bernardino Valley, S. B. \& W.F. Parish 6I3; Parish 5I63, and Nov., I902; San Luis Rey, Parry, I850; Potrero, Cleveland, I876; Fallbrook, Orcutt, Nov., I 883 ; near Imperial, G. D. Abrams, Jan., 1902; near Santa Ana, Helen D. Geis 548 .

3. Baccharis sarothroides A. Gray, Proc. Am. Acad. 17: 2 II. I882.

Type locality: "Southern borders of California, San Diego Co., near the old Mission Station, the boundary monuments, etc."

Distribution: In the extreme southern part of the State and adjacent Lower California, eastward to Arizona. Lower Sonoran.

Specimens examined: Boundary monument, near San Diego, Palmer 265; Mission Valley, Orcutt, Oct., I883; near San Diego Hayes, Oct. 14, 1858; San Felipe Canyon, Palmer, 1875; Chula, Vista, Abrams 4192; Jacumba Hot Spring, Abrams 3670.

4. Baccharis sergiloides A. Gray, Torr. Bot. Mex. Bound. 83. I859.

Type locality: "Along the Gila or Colorado, dry arroycs, 50 


\section{$(476)$}

miles west of the Colorado," also in the "southern part of California."

Distribution: From the western part of the Colorado and the Mohave Deserts, eastward to southern Utah. Lower Sonoran.

Specimens examined: Palm Springs, S. B. E W. F. Parish 206.

5. Baccharis glutinosa Pers. Syn. 2: 425. I 807.

Type locality: "An R[egni] Chilensis ruderatis."

Distribution: Along watercourses in the Colorado Desert, extending eastward to Arizona and southern Colorado, and southward into Mexico and Chili. This species has been reported from the coastal region near Los Angeles, but perhaps erroneously. Lower Sonoran.

Specimens examined: Imperial Valley, near Calexico, Abrams $4004,4093$.

6. Baccharis viminea DC. Prod. 5: 400 . 1836.

Type locality: "In California." First collected by Douglas.

Distribution: Common along watercourses and in moist places in southern California on the coastal slope; extending from the Sacramento Valley southward to northern Lower California. Upper and Lower Sonoran.

Specimens examined: Los Angeles, Brewer I7I; Grant 97; San Bernardino Valley, S. B. ध W.F. Parish 702; Sweetwater Valley, Deane, April 8, I888; San Diego River, Abrams 3380; Acton, Elmer 370I; vicinity of San Bernardino, Parish 5014; Big Tejunga wash, San Fernando Valley, Abrams 1393; Tia Juana River, Herre, Aug. 8, 1902; Monrovia, Dudley, Nov. 25, 1907; Los Angeles, Grant 97; Rock Creek, San Gabriel Mountains, Abrams छ McGregor 557 .

7. Baccharis Plummerae A. Gray, Proc. Am. Acad. 15: 48. I880.

Type locality: "Along a stream in Glen Loch ravine, in the mountains near Sta. Barbara, California."

Distribution: Santa Ynez Mountains northward to Santa Monica. Originally described as herbaceous, but distinctly woody, forming rounded bushes, about I meter high. Upper Sonoran. 
Specimens examined: La Cumbre trail, Santa Ynez Mountains, Abrams 4307 .

\section{Io. PLUCHEA.}

I. Pluchea sericea (Nutt.) Coville, Cont. Nat. Herb. 4: i28. 1893.

Polypappus sericeus Nutt. Journ. Acad. Philad. II. 1: I78. I847. Tessaria borealis DC.; Torr. \& Gray in Emory, Notes Mil.

Reconnois. I43. 1848, without description.

Tessaria borealis A. Gray, Pl. Wright. 1: 102. 1852.

Pluchea borealis A. Gray, Proc. Am. Acad. 17: 212. 1882.

Type locality: "Rocky Mountains of Upper California."

Distribution: Along watercourses, extending from Santa Barbara County southward into Lower California, and eastward through the Mohave and Colorado Deserts to the Rio Grande. This species, which is commonly called "arrow-weed," is very common along ditches in the Imperial Valley. Lower Sonoran.

Specimens examined: Santa Clara Valley, Ventura County, Rothrock 184; San Diego, Palmer, I875; Mohave Desert, Brandegee; Calexico, Abrams 4096; Tia Juana River, Abrams 3515; San Miguel Mountain, Chandler 5195.

\section{BEBBIA.}

Herbage green and glabrous.

Herbage scabrous.
I. B. juncea.

Ia. B. juncea aspera.

I. Bebbia juncea (Benth.) Greene, Bull. Calif. Acad. 1: 180. 1885.

Carphephorus junceus Benth. Bot. Sulph. 2I. 1844. Type locality: "Bay of Magdalena," Lower California.

Distribution: Western base of the San Bernardino Mountains, southward in the coastal region to northern Lower California. Lower Sonoran.

Specimens examined: City Creek wash, near Highlands, Abrams 2803; Santiago Canyon, Santa Ana Mountains, Helen D. Geis, Dec., 1902; between Grantville and Santee, Abrams 375.5; Canyon of the San Jacinto River, Hall 20r6; Santa Ana Canyon, San Bernardino Mountains, Shaw E Illingsworth, Aug. IO, IgoI. 


\section{$(478)$}

Ia. Bebbia juncea Aspera Greene, Bull. Calif. Acad. 1: iso. I 885 .

Bebbia aspera Nelson, Bot. Gaz. 37: 273. 1904.

Type locality: "Southeastern borders of California and adjacent Arizona."

Distribution: Common in sandy washes in the Colorado Desert, extending northward through the Mohave Desert, and eastward to southern Nevada and Arizona. Specimens have also been found on the coastal slope in southern California. Lower Sonoran.

Specimens examined: "San Diego," Brandegee; Signal Mountain, Abrams $316 r$.

\section{I2. VIGUIERA.}

Leaves lanceolate; achenes sparsely pubescent.

Leaves ovate; achenes densely villous.

1. V. laciniata.

2. V. Parishii.

I. Viguiera laciniata A. Gray, Bot. Mex. Bound. 89. 1859.

Type locality: "Rancho Gamacho, east of San Diego, Califronia."

Distribution: A common shrub on the mesas and foothills in the southwestern part of San Diego County, extending into adjacent Lower California. Lower Sonoran.

Specimens examined: Rancho Gamacho, east of San Diego, Schott, Sept., I 855 (type); near San Diego, Newberry; Sweetwater, Cleveland, April, I876; Cottonwood Grade, near Potrero, Abrams 390r; San Diego, Susan G. Stokes, June 20, I895; Mission Hills, San Diego, Abrams 3450.

2. Viguiera Parishii Greene, Bull. Torrey Club 9: I5. I882.

Viguiera deltoidea Parishii Rose, Cont. Nat. Herb. 1: 72. 1890. Type locality: "San Luis Rey."

Distribution: Western San Diego County, where it is rare, eastward to the Providence Mountains. Upper and Lower Sonoran.

Specimens examined: San Luis Rey, S. B. E W. F. Parish 963 (type); Palm Springs, Parish $4 I 26$.

Peduncles pubescent.

\section{I3. ENCELIA.}

Rays present.

Involucre densely villous; disk purple.

I. E. californica. 
Involucre canescent; disk yellow.

Rays none; herbage scabrous.

Peduncles glabrous; leaves silvery tomentose.
2. E. actoni.

3. E. frutescens.

4. E. farinosa.

I. Encelia californica Nutt. Trans. Am. Phil. Soc. 7: 357. I 84 I.

Type locality: "On dry hills, near St. Barbara, Upper California."

Distribution: Common on hillsides from Santa Barbara southward on the coast slope to northern Lower California. Confined mainly to the Upper Sonoran but extending into the Lower Sonoran toward its southern limits.

Specimens examined: Santa Barbara, Bolander, r873; hills near Inglewood, Abrams 3107; Santa Monica Canyon, Abrams 1486; San Diego, Susan G. Stokes, June 12, I895; Santiago Canyon, Santa Ana Mountains, Helen D. Geis 540; Santa Barbara, Elmer 3899; hillsides at Tia Juana, Abrams 3479.

2. Encelia actoni Elmer, Bot. Gaz. 39: 47. 1905.

Encelia frutescens f. actoni Hall, Univ. Calif. Pub. Bot. 3: I35. 1907.

Type locality: "Acton, Los Angeles county, California."

Distribution: Western slopes of the Mohave and Colorado Deserts, extending into the coastal region in the vicinity of San Jacinto. Lower Sonoran.

Specimens examined: Acton, Elmer 3724 (type); Hesperia, Parish 4873; San Felipe, Susan G. Stokes, July 28, 1895; Ventura, Brandegee; Jacumba Hot Spring, Abrams 3667; San Jacinto, Hall 2907; Liebre Mountains, Abrams Eऽ McGregor 402; between Tehachapi and Mohave, Abrams E๐ McGregor 500; Rock Creek, Abrams है McGregor 548 .

3. Encelia frutescens A. Gray, Proc. Am. Acad. 8: 657. 1873. Simsia frutescens A. Gray, Bot. Mex. Bound. 89. 1859.

Encelia frutescens f. ovata Hall, Univ. Calif. Pub. Bot. 3: I35. 1907.

Type locality: "Sierra Prieta, near Fort Yuma, E. California."

Distribution: Dry hillsides and washes of the Colorado and Mohave Deserts, eastward to Arizona and southern Nevada. Lower Sonoran. 
Specimens examined: Signal Mountain, Abrams 3156, and Dec. 29, 1907; McCoy wash, Colorado Desert, Hall 5939.

4. E.ncelia farinosa A. Gray; Torr. in Emory, Notes Mil. Reconnois. I43. I848.

Type locality: According to Emory's notes (page 103) this species was collected in southern California in the vicinity of Carriso Creek.

Distribution: San Bernardino Valley, southward to northern Lower California and eastward to Arizona. Lower Sonoran.

Specimens examined: Vicinity of San Bernardino, Parish 4782; Signal Mountain, Abrams 3159; near Mentone, Abrams छ McGregor 823 .

\section{I4. PICROTHAMNUS.}

I. Picrothamnus desetorum Nutt. Trans. Am. Phil. Soc. II. 7: 417. 1841 .

Artemisia spinescens Eaton, Bot. King. Exped. 180, pl. 19. 1871. Type locality: "North sources of the Platte."

Distribution: Mohave Desert of southern California extending northward throughout the Great Basin region. Upper Sonoran.

Specimens examined: I have not seen any specimens within our range.

\section{I5. ARTEMisia. SAge-brush.}

Heads heterogamous; marginal flowers pistillate, the central perfect; leafsegments filiform.

r. A. californica.

Heads homogamous; the flowers all perfect; leaf-segments not filiform.

Achenes glabrous.

Involucre oblong, 3-8, or rarely 9-flowered.

Accessory bracts of the involucre short and ovate.

2. A. tridentata.

Accessory bracts of the involucre oblong or lanceolate.

3. A. tripartita.

Involucre short-campanulate, 9-I2-flowered; bracts all ovate or oval, glabrate.

Achenes pubescent.

4. A. Rothrockii.

5. A. Parishii.

I. Artemisia californica Less. Linnaea 6:523. 1831 . Artemisia abrotanoides Nutt. Trans. Am. Phil. Soc. II. 7: 399. I84I. 
Artemisia foliosa Nutt. Trans. Am. Phil. Soc. II. 7: 397. I84I. Type locality: "De Chamisso in California."

Distribution: San Francisco Bay, southward through the Coast Ranges to Lower California. Upper Sonoran.

Specimens examined: Sierra Santa Monica, Brewer 53; sandy plains near Colton, Pringle, Oct. 22, 1882; San Luis Rey, Parry; Santa Barbara, Elmer 3964; near Oneonta, Herre, Aug. 8, 1902.

2. Artemisia tridentata Nutt. Trans. Am. Phil. Soc. II. 7: 398. I84I.

Type locality: "Hab. Plains of the Oregon, and Lewis River."

Distribution: Eastern Washington, eastward throughout the arid regions of the Rocky Mountains, and southward to Lower California. In southern California it is common on the desert slopes of the mountains in, and just below, the yellow pine belt. Arid Transition and Upper Sonoran.

Specimens examined: Holcomb Valley, San Bernardino Mountains, Shaw E Illingsworth $2 x I$.

3. Artemisia tripartita Rydb. Mem. N. Y. Bot. Gard. 1: 432. 1900.

Artemisia trifida Nutt. Trans. Am. Phil. Soc. II. 7: 398. I841. Not Turcz. 1832.

Type locality: "Placers of the Rocky Mountains and Oregon."

Distribution: Mohave Desert, extending eastward and northward through the Great Basin region. Upper and Lower Sonoran.

Specimens examined: I have not seen any specimens from southern California.

4. Artemisia Rothrockin A. Gray, Bot. Calif. 1: 6i8. 1876.

Type locality: "Sierras of Tulare Co., Olanche Mountains and Monachay Meadows, at 8,000 to 9,300 feet."

Distribution: Southern Sierra Nevada, south to the San Bernardino Mountains, and east to southern Utah. Arid Transition and Upper Sonoran.

Specimens examined: I have not seen any specimens from southern California. 
5. Artemisia Parishii A. Gray, Proc. Am. Acad. 17: 220.1882.

Type locality: "Newhall, Los Angeles Co., and in Cajon Pass, California." According to Parish (Zoe 5: I20), "the second station 'Cajon Pass' given in the original description is an error. The plant has been found, as yet, only at Newhall."

Distribution: A common plant in the vicinity of Newhall and in Antelope Valley often forming large shrubs 2 meters high or more. Much of this material has been mistaken heretofore for Artemisia tridenta angustifolia A. Gray, with which it is closely related if not identical.

Specimens examined: Newhall, S. B. छ W. F. Parish 1065; Helen D. Geis; near Lancaster, Wells, Dec., I909; near Burbank, Braunton 907.

\section{I6. LEPIDOSPARTUM.}

I. Lepidospartum squamatum A. Gray, Proc. Am. Acad. 19: 50. I 883 .

Linosyris squamata A. Gray, Proc. Am. Acad. 8: 290. 1870.

Linosyris squamata Breweri A. Gray, Proc. Am. Acad. 8: 290. I 870.

Linosyris squamata Palmeri A. Gray, Proc. Am. Acad. 8: 290. I870.

Tetradymia squamata A. Gray, Proc. Am. Acad. 9: 207. 1874.

Type locality: "Low hills of the Sierra Santa Monica, Los Angeles Co., Californica." When Dr. Gray first published his diagnosis of this species he had only two specimens in his herbarium. One of these, collected by Brewer on "low hills of the Sierra Santa Monica, Los Angeles Co., California," was placed in the variety Breweri; the other, collected on the "desert of the Colorado, Arizona, 1870 [by] Dr. E. Palmer," became his second variety, Palmeri. This treatment, fortunately seldom practiced by Dr. Gray, left no specimens to represent the typical species. We are therefore obliged to consider the Brewer plant as the type of the species, reducing the varietal name to synonymy. The desert form, Palmeri, does not seem distinct.

Distribution: Southern Monterey County, southward to Lower California, and eastward to Arizona. Dry sandy washes in the Upper and Lower Sonoran.

Specimens examined: Fort Tejon, Heerman; Rothrock 276; 


\section{$(483)$}

Sierra Santa Monica, Brewer $7 I$ (type); San Gabriel Canyon, Abrams 885: San Antonio Canyon, Baker 3466; Santiago Canyon, Santa Ana Mountains, Helen D. Geis 576; vicinity of San Bernardino, Parish 4202, 5130; foothills of the San Bernardino Mountains, S. B. E० W. F. Parish 583; Riverside, Hall 1367; Mohave Desert, Brandegee; wash near Monrovia, Dudley, Nov. I3, 1907.

\section{PEUCEPHYLLUM.}

I. Peucephyllum Schottil A. Gray, Bot. Mex. Bound. 74 . I859.

Psathyrotes Schottii A. Gray, Proc. Am. Acad. 9: 206.1874. Inyonia dysodioides M. E. Jones, Cont. W. Bot. no. 8: 42 . 1898.

Type locality: "Diluvial banks of the Colorado, in Sonora."

Distribution: Inyo County, southward through the desert region to Lower California and Sonora. Lower Sonoran.

Specimens examined: Los Palmas, Hall 5849.

\section{8. TETRADYMIA.}

Heads 4-flowered; plants not spinescent.

Leaves permanently canescent.

I. T. canescens.

Leaves glabrate.

2. T. glabrata

Heads 5-9-flowered.

Stems clothed with slender spines; leaves not spinescent-tipped.

Achenes canescent but glabrate.

Achenes with long, soft wool.

3. T. sienolepis.

4. T. spinosa.

Stems without spines; leaves spinescent-tipped; achenes with long, soft wool.

5. T. comosa.

I. Tetradymia canescens DC. Prod. 5: 440. 1837.

Type locality: "In Americae borealis ora occidentali ad Columbia River."

Distribution: Eastern Washington and Idaho, southward to the mountains of southern California. Arid Transition.

Specimens examined: Mount San Antonio, S. B. E W.F. Parish 561; Bear Valley, Abrams 2013, 2135; Mount San Antonio, Abrams 2693; Water Canyon, Tehachapi Mountains, Abrams E McGregor 469.

2. Tetradymia glabrata A. Gray, Pacif. R. Rep. 2: i22, pl. 5. 1854 .

Type locality: "On the Sierra Nevada." 


\section{$(484)$}

Distribution: Mohave Desert, northward through the arid regions to eastern Oregon. Upper and Lower Sonoran.

Specimens examined: Mohave Desert, Pringle, May 24, I882; Rabbit Springs, S. B. \& W. F. Parish 1259; Lancaster, Elmer 3676; Dudley 43r3.

3. Tetradymia stenolepis Greene, Bull. Calif. Acad. 1: 92. 1885 .

Type locality: "Mountains of Kern Co., California." According to Hall (Univ. Calif. Pub. Bot. 3: 227) "the type specimens were gathered a short distance southwest of the Southern Pacific railroad between Cameron and Mohave stations."

Distribution: Mohave Desert, from Antelope Valley eastward to Inyo County. Lower Sonoran.

Specimens examined: Cushenberry Springs, Abrams 2149; Antelope Valley, Oliver; hills near Kernville, Purpus 565I; Tehachapi, Mrs. Curran, I884; Mohave Desert, Davidson, Aug. I, Igor; between Tehachapi and Mohave, Abrams छै McGregor 496.

4. Tetradymia spinosa Hook. \& Arn. Bot. Beech. $360 . \quad$ i840.

Type locality: "Snake Country." First collected by Tolmie.

Distribution: Eastern Oregon and Idaho, southward through the Great Basin to the Mohave Desert. Lower Sonoran.

Specimens examined: Mohave Desert, Pringle, May 14, I882; Lancaster, Elmer 3670.

5. Tetradymia comosa A. Gray, Proc. Am. Acad. 12: 6o. 1876.

Type locality: "W. Nevada, Lemmon, S. E. borders of California, E. Palmer, Potrero, San Diego Co. D. Cleveland."

Distribution: Southern Nevada, to the southern boundary of California. In southern California this species is most frequent on the dry interior hills and plains of the coastal slope, but it also occurs, according to Parish, on the Mohave Desert in the vicinity of Lancaster and Hesperia.

Specimens examined: Potrero, Cleveland, г876; Susan G. Stokes, July I4, I895; vicinity of San Bernardino, Parish, July, 1899; Cucamonga, Abrams 2942; Etiwanda, Abrams 1912; near San Jacinto, Hasse, July 4, I892; Campo, Palmer 95. 


\section{$(485)$}

\section{I9. SENECIO. Groundsel.}

I. Senecio Douglasii DC. Prod. 6: $429 . \quad$ i 837.

Senecio regiomontanus DC. Prod. 6: 429. 1837.

Senecio longilobus Benth. Pl. Hartw. I8. I839.

Senecio filifolius Nutt. Trans. Am. Phil. Soc. 7: 4II. I 847.

Senecio Riddellii Torr. \& Gray, Fl. N. Am. 2: 444. 1840.

Senecio Blochmanae Greene, Erythea 1: 7. I893.

Type locality: "In California." First collected by Douglas.

Distribution: Lake County, southward to Lower California, and eastward to western Texas and Nebraska; common in dry sandy washes. Upper and Lower Sonoran.

Specimens examined: Tia Juana, Abrams 35II; Lytle Creek Canyon, Abrams 269o; Little Santa Anita Canyon, San Gabriel Mountains, Abrams 2646; near Orange, Agnes M. Bowman, June, 1899; San Felipe, Susan G. Stokes, July 24, I895; near San Bernardino, Parish 5103; Acton, Elmer 3735; Sespe Creek, near Ten Sycamore Flat, Abrams \& McGregor I70; Cajon Pass, Abrams छ McGregor 697. 





\section{QK484.C2 A2}

Abrams, LeRoy/A phytogeographic and taxo

|| || || || || || || || || | ||||| ||| || || || || |||||||||||

3518580112806 
